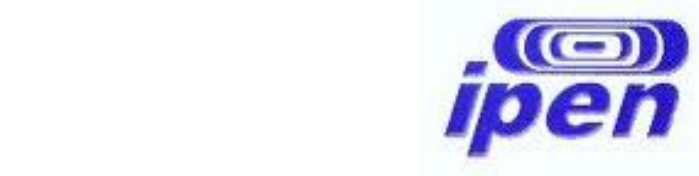

INSTITUTO DE PESQUISAS ENERGÉTICAS E NUCLEARES

Autarquia associada à Universidade de São Paulo

\begin{abstract}
MODIFICAÇÃO DA SUPERFÍCIE DE AÇO ELETROZINCADO PARA PROTEÇÃO CONTRA A CORROSÃO POR REVESTIMENTOS ISENTOS DE CROMO
\end{abstract}

JOSÉ MÁRIO FERREIRA JÚNIOR

Tese apresentada como parte dos requisitos para a obtenção do Grau de Doutor em Ciências na Área de Tecnologia Nuclear Materiais.

Orientadora:

Profa. Dra. Isolda Costa

São Paulo 2014 


\section{AGRADECIMENTOS}

Aos meus pais, José Mário Ferreira (in memorium) e Dervanda Defina.

À minha irmã Veridiana Defina Ferreira, aos meus poucos e bons amigos, que direta ou indiretamente, me ajudaram e ajudam, e assim se tornaram irmãos que a vida me deu.

À Elba Karina Martins, que com seu amor e compreensão me faz querer ser uma pessoa melhor.

À Profa. Doutora Isolda Costa, pela amizade, paciência e, principalmente, pelo entusiasmo e competência empregados na orientação deste trabalho.

À professor Doutor Mark Alan Baker pela sua supervisão e paciência durante minhas visitas a Inglaterra até encontrarmos nas ciências exatas uma forma de linguagem comum.

Ao Conselho Nacional de Desenvolvimento Científico e Tecnológico - CNPq pelo financiamento por meio de bolsa de doutorado - processo 143420/2009-7, Chamada/Edital: Ed702008 ME/DO-Edital MCT/CNPq no 70/2008 Mestrado/Doutorado.

Ao Instituto de Pesquisas Energéticas e Nucleares - IPEN, pela disponibilidade de lotação, materiais e conhecimento científico.

À University of Surrey por possibilitar em duas ocasiões a realização de análises de superfície por meio de técnicas de caracterização avançadas. 
Nobody ever told me, I found out for myself, You gotta believe in foolish miracles, it's not how you play the game, it's if you win or lose, you can choose, don't confuse, win or lose.

\section{Ozzy Osbourne}




\title{
ODIFICAÇÃO DA SUPERFÍCIE DE AÇO ELETROZINCADO PARA PROTEÇÃO CONTRA A CORROSÃO POR REVESTIMENTOS ISENTOS DE CROMO
}

\author{
JOSÉ MÁRIO FERREIRA JÚNIOR
}

\begin{abstract}
RESUMO
Os revestimentos eletrozincados empregados como proteção galvânica ativa sobre os aços são utilizados industrialmente há longo tempo. Entretanto, como o zinco é um elemento muito reativo, o tratamento da sua superfície é necessário para aumentar sua vida útil. O tratamento mais utilizado consiste em imersão em solução de conversão contendo cromo hexavalente, o qual vem sendo banido por gerar substâncias tóxicas e carcinogênicas, tendo sua utilização proibida pelas normas europeias. Neste trabalho, foram estudados tratamentos alternativos ao cromato para o aço eletrozincado que não geram resíduos tóxicos. O tratamento escolhido foi desenvolvido em etapas. A primeira etapa envolveu o uso de um composto orgânico, o 2 butino-1,4 diol propoxilato, em solução com sais oxidantes e com nitrato de cério como aditivo. A etapa seguinte consistiu em imersão da superfície tratada pela etapa anterior, em um agente oxidante, o peróxido de hidrogênio. A terceira etapa consistiu na imersão em solução com 2 butino-1,4 diol propoxilato e oxalato de nióbio amoniacal (ANO). As superfícies tratadas, após cada uma das etapas, foram caracterizadas por microscopia óptica e eletrônica de varredura (MEV), difração de raios $X(D R X)$, espectroscopia por infravermelho (FTIR) e espectroscopia fotoeletrônica de raios $X$ (XPS). A caracterização quanto à corrosão das superfícies tratadas foi feita por ensaios de névoa salina e espectroscopia de impedância eletroquímica (EIE). Os resultados mostraram que cada uma das etapas teve uma contribuição no aumento da resistência à corrosão e esta foi dependente do tempo de tratamento em cada uma das três etapas. A composição química das camadas obtidas foi caracterizada por FTIR e XPS. Esta última técnica permitiu analisar a distribuição dos elementos nas camadas formadas ao longo da espessura da mesma, usando a técnica de desbaste (sputtering), obtendo perfis de profundidade. A presença de ácido carboxílico ligado ao substrato metálico (zinco) foi observada. Os resultados mostraram que ocorreu formação de camada orgânica e a incorporação de cério e de nióbio a esta camada. Estes se apresentam distribuídos em toda a extensão da camada, na forma de óxidos em dois estados de oxidação, III e IV, no caso do cério, e IV e V, no caso do nióbio. As camadas formadas após as várias etapas adotadas contêm uma estrutura polimérica formada por filme orgânico e uma mistura de óxidos, particularmente óxido e hidróxido de zinco, os quais ficam retidos na estrutura da camada e conferem proteção à corrosão do substrato metálico por períodos prolongados de imersão. Os resultados quanto a proteção à corrosão mostraram que o tratamento com o melhor desempenho (T10_10_10) proporcionou proteção ao substrato por longos períodos de tempo e esta foi superior em comparação à promovida por camada de cromato, tanto pelo ensaio de névoa salina como o de EIE. Este tratamento mostrou-se, portanto, uma alternativa promissora para substituição de camada de cromato na proteção de aço eletrozincado, tanto do ponto de vista ambiental, por não gerar resíduos tóxicos, como de resistência à corrosão.
\end{abstract}




\title{
SURFACE MODIFICATION OF ELECTROGALVANIZED STEEL FOR PROTECTION AGAINST CORROSION FOR COATINGS FREE CHROME
}

\author{
JOSÉ MÁRIO FERREIRA JÚNIOR
}

\begin{abstract}
Electrogalvanized coatings are employed as active galvanic protection to steel and its applications have been used industrially for a long time. However, as zinc is a very reactive element, the treatment of the surface is necessary to increase its lifespan. The most common treatment consisted of a conversion treatment in solution containing hexavalent chromium, which has been banned by generating toxic and carcinogenic substances, and its use prohibited by European standards. In this work, surface treatments alternative to chromating for electrogalvanized steel that do not generate toxic waste were studied. The chosen treatment was developed in stages. The first stage involved the use of an organic compound, 2 butyne 1,4 diol propoxylate in solution with oxidizing salts and cerium nitrate as an additive. The next step involved immersing the treated surface by the previous step in an oxidizing agent, hydrogen peroxide. The third step consisted of immersion in solution with 2-butyne 1,4 diol propoxylate and ammonium niobium oxalate (ANO). Treated surfaces after each step were characterized by optical microscopy and scanning electron microscopy (SEM), X-ray diffraction (XRD), infrared spectroscopy (FTIR) and photoelectron spectroscopy X- ray (XPS). The characterization for corrosion of the treated surfaces was made by salt spray tests and electrochemical impedance spectroscopy (EIS). The results showed that each step has a contribution in increasing the corrosion resistance and this was dependent on the treatment time adopted in each of the three stages. The chemical composition of the layers obtained was characterized by FTIR and XPS. This last technique allowed to analyze the distribution of the elements in the layer formed along its thickness, by sputtering the surface to obtain depth profiling. The presence of carboxylic acid bonded to the metal substrate (zinc) was observed. The results showed that there was formation of organic layer and the incorporation of cerium and niobium this layer. These elements were distributed throughout the length of the layer in the form of oxides in two oxidation states; in the case of cerium, as III and IV, and IV and V, in the case of niobium. The layers formed after the various steps contain a polymeric structure and a mixture of oxides/hydroxide, particularly of zinc, which are retained in the structure of the layer and provide corrosion protection to the metal substrate for prolonged periods. The corrosion results showed that the best treatment (T10_10_10) provided protection to the substrate for long periods of time and that was higher compared to that promoted by the chromate layer, either by the salt spray test as the EIS test. Therefore, this treatment proved a promising replacement to chromate layer in the corrosion protection of electrogalvanised steel, either from its corrosion properties or from an environmental point of view.
\end{abstract}




\section{Índice}

Lista de Equações.................................................................... VIII

Lista de Figuras............................................................................. $\mathrm{X}$

Lista de Tabelas......................................................................... XVI

1. INTRODUÇÃO.................................................................. 1

1.1. Considerações Ambientais....................................................... 4

1.2. Justificativa para o tema........................................................ 5

1.2.1. Emprego do Cério.................................................................. 5

1.2.2. Emprego do Nióbio.................................................................. 7

2. OBJETIVOS

2.1. Objetivo geral.............................................................. 10

2.2. Objetivos específicos......................................................... 10

3. REVISÃO DA LITERATURA ................................................ 11

3.1. Revestimentos de zinco........................................................ 11

3.2. Tratamentos de proteção sobre camada de zinco........................... 14

3.2.1. Camadas de conversão de cromato............................................... 14

3.2.2. Revestimentos à base de cério................................................... 21

3.2.3. Tratamentos em soluções contendo compostos de nióbio................. 25

4. MATERIAIS E MÉTODOS .................................................. 29

4.1. Eletrogalvanização do aço SAE/AISI 1010 …….......................... 29

4.2. Determinação da espessura da camada de zinco obtida................. $\quad 30$

4.3. Tratamentos de passivação..................................................... 31

4.4. Caracterização das camadas obtidas (diferentes tratamentos testados) ............................................................................... 35

4.4.1. Caracterização química........................................................... 35

4.4.1.1. Espectroscopia no infravermelho por transformada de Fourier (FTIR) ..................................................................... 35

4.4.1.2. Espectroscopia fotoeletrônica de raios X (XPS)............................. 36

4.4.2. Caracterização Superficial (Morfológica e estrutura de

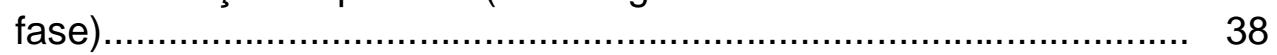

4.4.3 Ensaios acelerados em câmara de névoa salina.............................. 38

4.4.4. Caracterização eletroquímica....................................................... 39

5. RESULTADOS E DISCUSSÃO............................................. 41

5.1. Morfologia dos depósitos de zinco (substrato).............................. 41

5.2. Caracterização das soluções passivadoras..................................... 45

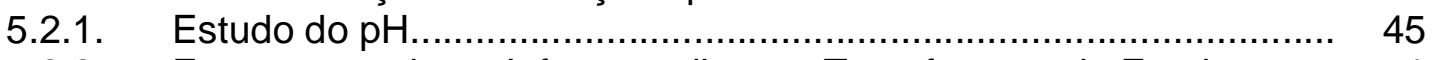

5.2.2. Espectroscopia no Infravermelho por Transformata de Fourier........ 51

5.3. Tratamentos de proteção da superfície de aço eletrozincado........... 55 
5.3.1. Efeito do tempo de imersão em solução contendo cério........... 56

5.3.1.1. Morfologia (Microscopias de Emissão, Microscopia Óptica tridimensional e Difração de raios $\mathrm{X}$ )

5.3.1.2. Análise da composição química (Espectroscopia no Infravermelho por Transformata de Fourier e Espectroscopia Fotoeletrônica de Raios X)

5.3.1.3. Observações gerais / respostas às perguntas propostas................ 76

5.3.1.4. Resultados eletroquímicos (Ensaios de corrosão acelerada e Espectroscopia de Impedância Eletroquímica)

5.3.2. Efeito do tempo de imersão em solução de peróxido de hidrogênio.

5.3.2.1. Morfologia (Microscopias de Emissão, Microscopia Óptica tridimensional e Difração de raios X)

5.3.2.2. Análise da composição química (Espectroscopia no Infravermelho por Transformata de Fourier e Espectroscopia Fotoeletrônica de Raios X...)....

5.3.2.3 Resultados eletroquímicos (Ensaios de corrosão acelerada e Espectroscopia de Impedância Eletroquímica).

5.3.3. Efeito do tempo de imersão em solução de oxalato de nióbio amoniacal (ANO).

5.3.3.1. Morfologia (Microscopias de Emissão e Óptica tridimensional).......

5.3.3.2 Análise da composição química (Espectroscopia no Infravermelho por Transformata de Fourier e Espectroscopia Fotoeletrônica de Raios X).

5.3.3.3 Resultados eletroquímicos (Ensaios de corrosão acelerada e Espectroscopia de Impedância Eletroquímica).

5.3.4 Modelos propostos

6. CONCLUSÕES

7. SUGESTÕES PARA TRABALHOS FUTUROS 


\section{Lista de Equações}

(1) Reação de corrosão do metal (oxidação)............................................. 3

(2) Redução do cromo hexavalente..................................................... 3

(3) Reação de oxidação do zinco: ...................................................... 12

(4) Reação de redução de oxigênio em meio ácido.................................. 12

(5) Reação de redução de oxigênio em meio ácido................................... 12

(6) Reação de redução de oxigênio em meio básico.................................. 12

(7) Reação de formação de hidróxido de zinco....................................... 12

(8) Reação de formação de carbonato................................................... 12

(9) Reação de formação de hidrozincato................................................... 12

(10) Reação de redução de zinco metálico.................................................. 16

(11) Reação de cromato em meio ácido.................................................. 16

(12) Reação de hidróxido de cromo trivalente em meio ácido...................... 16

(13) Reação de zinco com dicromato em meio ácido.................................. 18

(14) Reação de precipitação de cromo trivalente em meio básico................. 18

(15) Reação de formação de cromato...................................................... 18

(16) Reação de formação de camada de conversão de cromato.................. 18

(17) Reação de oxidação de cério trivalente por peróxido de hidrogênio...... 23

(18) Reação de formação de óxido de cério III............................................ 24

(19) Reação de formada pela adsorção de complexos de íons de cério na superfície hidroxilada do zinco (etapa 1).......................................... 24

(20) Reação de formada pela adsorção de complexos de íons de cério na superfície hidroxilada do zinco (etapa 2)........................................... 24

(21) Reação de formada pela adsorção de complexos de íons de cério na superfície hidroxilada do zinco (etapa 3 ) 
(22) Reação de redução de nitrato em meio ácido..................................... 47

(23) Reação de complexação de cério em meio aquoso (etapa 1).............. 47

(24) Reação de complexação de cério em meio aquoso (etapa 2)............ 47

(25) Reação de precipitação de hidróxido de cério III................................. 47

(26) Reação de formação de óxido cério IV............................................. 47

(27) Expressão para cálculo do IDH .................................................. 54 


\section{LISTA DE FIGURAS}

Figura 1: Representação esquemática do processo de self healing em trinca ou poro na superfície de aço eletrozincado com camadas de cromato. (Adaptado de Hughes, (HUGHES,2010))

Figura 2: Representação esquemática para a formação do $\mathrm{Cr}(\mathrm{OH})_{3}$ nas regiões de defeito no processo de auto-cura (ZHANG, 1996).....

Figura 3: Representação esquemática de um produto misto de óxido de $\mathrm{Cr}$ III e $\mathrm{VI}$ adsorvidos ao substrato de aço galvanizado (ZHANG, 1996)

Figura 4: Representação esquemática do processo de eletrodeposição utilizado

Figura 5: Diferentes pontos adotados para análise por XPS, respectivamente para as amostras com tratamentos: (A) T1; (B) T10 e (C) T20.

Figura 6: Representação esquemática do arranjo experimental adotado

Figura 7: Micrografia obtida por FEG (1000x) para amostra de aço SAE/AISI 1010 eletrodepositado após polimento químico

Figura 8: A) Micrografia obtida por FEG de secção transversal de aço eletrozincado criofraturado, em atmosfera de nitrogênio líquido $\left(\mathrm{N}_{2}\right)$; B) Espectro de EDS em linha

Figura 9: A) Micrografia obtida por FEG da secção transversal de aço eletrozincado polido; B) Espectro de EDS em linha

Figura 10: Micrografias obtidas por MEV (aumento 1000X) das superfícies de aço eletrozincado: A) sem ativação e B) com ativação em ácido nítrico diluído $(\mathrm{pH} 1)$

Figura 11 Diagrama de Pourbaix, faixa de $\mathrm{pH}$ das soluções de tratamentos e as reações dos compostos inorgânicos, cério e nióbio.

Figura 12: Evolução do pH em função do tempo desde a preparação da solução de tratamento contendo nitratos de sódio e cério, sulfato de sódio e 2 butino1,4diol propoxilato.

Figura 13: Evolução do $\mathrm{pH}$ em função do tempo desde a preparação da solução de tratamento contendo oxalato de nióbio amoniacal, nitrato de sódio, sulfato de sódio e 2 butino-1,4diol propoxilato. 
Figura 14: Representação estrutural de uma via reacional proposta para 2 butino-1,4 diol propoxilato em meio oxidante (nitrato e sulfato).

Figura 15: Representação, fórmulas estruturais, de vias reacionais propostas para oxidação de propanol (álcoois) e aldeídos até a formação de ácidos carboxílicos. Os reagentes A e B correspondem aos produtos finais indicados na Figura 14

Figura 16: Micrografias obtidas por FEG para amostras: (A) com camada de conversão de cromato e $(\mathrm{B})$ após tratamento $\mathrm{T1}$

Figura 17 Micrografias obtidas por FEG $(1000 \mathrm{X})$ para as amostras com tratamentos em: A) T10 e B) T20. Correspondentes a imersão da peça eletrozincada, respectivamente por 10 e 20 minutos em solução contendo nitrato de cério hexahidratado, 2 butino 1,4 diol propoxilato, nitrato sódio e sulfato de sódio.

Figura 18: Imagens tridimensionais obtidas por microscópio ótico, aumento 50 $\mathrm{X}$, a superfície com tratamento T1 (1 minuto em solução contendo nitrato de cério hexahidratado, de 2-Butino-1,4-diol propoxilato, nitrato de sódio e sulfato de sódio)

Figura 19: Imagens tridimensionais obtidas por microscópio ótico, aumento 50 $X$, a superfície com tratamento T10 (10 minutos em solução contendo nitrato de cério hexahidratado, de 2-Butino-1,4-diol propoxilato, nitrato de sódio e sulfato de sódio).

Figura 20. Imagens tridimensionais obtidas por microscópio ótico, aumento 50 $X$, a superfície com tratamento T20 (20 minutos em solução contendo nitrato de cério hexahidratado, de 2-Butino-1,4-diol propoxilato, nitrato de sódio e sulfato de sódio).

Figura 21: Difratograma obtido por difração de raios $X(X R D)$ das superfícies com os tratamentos T1, T10 e T20, respectivamente, imersas por 1, 10 e 20 minutos em solução de tratamento contendo cério...

Figure 22: Espectros normalizados de FTIR das superfícies com os tratamentos T1, T10 e T20 sobre aço eletrozincado.

Figura 23: Representações estruturais para tipos de ligações entre ácidos carboxílicos e metais. A) ligação monodentada; B) ligação bidentada e C) ligação ponte.

Figura 24: Espectros gerais obtidos por Espectroscopia Fotoeletrônica de Raios X (XPS) das camadas formadas em superfície de aço eletrozincado, pelos tratamentos T1, T10 e T20. 
Figura 25: Figura 25: Espectros de XPS para os elementos C 1s, O 1s, Ce 3d e Zn $2 \mathrm{p}$ da superfície do aço eletrozincado após tratamento por 1 minuto (T1).....

Figura 26: Espectros de XPS para os elementos C 1s, O 1s, Ce 3d e Zn 2p na superfície do aço eletrozincado após tratamento por 10 minutos (T10).

Figura 27: Espectro de XPS dos componentes, C 1s, O 1s, Ce 3d e Zn 2p para a superfície de aço eletrozincado e passivado por imersão por 20 minutos (T20).

Figura 28: Representação das ligações de zinco do substrato com o grupo carboxila da substancia ácido propanóico - formação de camada polimérica sobre zinco.

Figura 29: Representação das ligações de zinco do substrato com o grupo carboxila da substancia ácido but-2enóico - formação de camada polimérica sobre zinco.

Figura 30: Diagramas de Nyquist para 1, 3 dias de imersão em solução de $\mathrm{NaCl} 0,1 \mathrm{M}$, das amostras de zinco (substrato), cromo VI, zinco com aditivo, T1, T10 e T20

Figura 31: Diagramas de Nyquist para 5, 7 dias de imersão em solução de $\mathrm{NaCl} 0,1 \mathrm{M}$, das amostras de zinco (substrato), cromo Vl, zinco com aditivo, T1, T10 e T20

Figura 32: Diagramas de Nyquist e Bode (ângulo de fase) obtidos entre 1 e 7 dias de imersão em solução de $\mathrm{NaCl} 0,1 \mathrm{M}$ para amostra com tratamento T10

Figura 33: Circuitos elétricos equivalentes (CEE) utilizados nos ajustes dos dados de espectroscopia de impedância eletroquímica: (A) arranjo com duas constantes de tempo em cascata para o primeiro dia, (B) arranjo com três constantes de tempo adotado do segundo ao setimo dia de imersão em $\mathrm{NaCl} 0,1 \mathrm{~mol}^{-\mathrm{L}^{-1}}$.....

Figura 34: Micrografias obtidas por FEG das superfícies tratadas por imersão em soluções: A) amostra com tratamento T10 (sem imersão em peróxido; B) amostra com tratamento T10_1

Figura 35: Micrografias obtidas por FEG para amostras tratadas por imersão em soluções de peróxido de hidrogênio por: A) 10 minutos, amostra com tratamento T10_10; B) 20 minutos, amostra com tratamento T10_20 
Figura 36: Micrografia ótica tridimensional para as amostras T10 (A), com diferentes tempos de imersão em peróxido de hidrogênio por: B) 1 minuto, amostra com tratamento T10_1, (C) 10 minutos, amostra com tratamento T10_10, e (D) amostra com tratamento T10_20........

Figura 37: Espectros de difração de raios $X$ (XRD) para a amostra com tratamentos T10_1, T10_10 e T10_20 respectivamente imersas por 1, 10 e 20 minutos em solução peróxido de hidrogênio.

Figura 38: Espectros normalizados de FTIR para as superfícies do aço eletrozincado após os tratamentos T10_1, T10_10 e T10_20............

Figura 39: Espectro geral obtido por Espectroscopia Fotoeletrônica de raios $X$ (XPS) da camada formada em superfície de aço eletrozincado, amostras com tratamento T10 imersas em solução de peróxido de hidrogênio por 1,10 e 20 minutos, respectivamente tratamentos T10_1, T10_10 e T10_20.

Figura 40: Espectros obtidos por Espectroscopia Fotoeletrônica de raios $X$ (XPS) para elementos C1s, O1s, Ce3d e Zn2p obtidos em função do tempo de sputtering (em segundos) da superfície do aço eletrozincado após tratamento por imersão da amostra T10 em solução de peróxido de hidrogênio por 10 minutos, amostra com tratamento T10_10 (Perfil de profundidade em função do tempo de sputtering)

Figura 41: Diagramas de Nyquist para 1 e 3 dias de imersão em solução 0,1 mol. L $^{-1}$ de $\mathrm{NaCl}$, das amostras com tratamentos T10, T10_1, T10_10 e T10_20.

Figura 42: Diagramas de Nyquist para 5 e 7 dias de imersão em solução 0,1 mol. $\mathrm{L}^{-1}$ de NaCl, das amostras com tratamentos T10, T10_1, T10_10 e T10_20.

Figura 43: Diagramas de Nyquist e Bode ângulo de fase de 1 a 7 dias de imersão em solução $0,1 \mathrm{~mol} . \mathrm{L}^{-1}$ de $\mathrm{NaCl}$, da amostra com tratamento T10_10.

Figura 44: Circuito elétrico equivalente (CEE) utilizado nos ajustes dos dados de espectroscopia de impedância eletroquímica, arranjo com três constantes de tempo adotado para dados obtidos de 1 a 7 dias de imersão em $\mathrm{NaCl} 0,1$ mol.L-1 , para amostra com tratamento T10_10

Figura 45: Micrografias obtidas por FEG $(1000 \mathrm{X})$ para os tratamentos: (A) T10_10 (sem imersão em solução contendo nióbio); (B) T10_10_1, imersa por 1 minuto em solução contendo nióbio. 
Figura 46: Micrografias obtidas por FEG $(1000 \mathrm{X})$ para as amostras com tratamento T10_10, tratadas por imersão em soluções contendo nióbio por 10 e 20 minutos, respectivamente tratamentos: (A) T1010_10 e (B) amostra T10_10_10.

Figura 47: Micrografia ótica tridimensional das amostras com tratamentos: A) T10_10, (B) T10_10_1, (C) T10_10_10 e (D) T10_10_20

Figura 48: Espectros normalizados de FTIR das camadas de conversão de cério formada em superfície, aço eletrozincado, de amostras com tratamentos T10_10_1, T10_10_10 e T10_10_20

Figura 49: Espectro geral obtido por Espectroscopia Fotoeletrônica de raios $X$ (XPS) da camada formada em superfície de aço eletrozincado, de amostras com tratamentos T10_10_1, T10_10_10 e T10_10_20.......

Figura 50: Espectros XPS para elementos C1s, O1s, Zn2p, Ce3d e Nb3d obtidos em função do tempo de sputtering (em segundos) da superfície do aço eletrozincado após tratamento por imersão da amostra T10_10 em solução contendo nióbio por 10 minutos, amostra com tratamento T10_10_10

Figura 51: Diagramas de Nyquist para 1, 5 dias de imersão em solução de $\mathrm{NaCl}$ 0,1 mol.. ${ }^{-1}$, das amostras com tratamentos T10_10, T10_10_1, T10_10_10 e T10_10_20

Figura 52: Diagramas de Nyquist e Bode ângulo de fase de 7, 9 e 11 dias de imersão em solução de $\mathrm{NaCl} 0,1 \mathrm{~mol}^{-L^{-1}}$, da amostra com tratamento T10_10_10

Figura 53: Diagramas de Nyquist de 1 a 3 dias de imersão em solução de $\mathrm{NaCl}$ 0,1 mol.. $L^{-1}$, da amostra T10_10, imersa por 10 minutos de imersão em solução contendo nióbio. (amostra T10_10_10).

Figura 54: Diagramas de Nyquist para 7, 21, 28, 35, 41, 59, 62 e 72 dias de imersão em solução de $\mathrm{NaCl} 0,1$ mol.L $\mathrm{L}^{-1}$, das amostras com tratamento T10_10_10

Figura 55: Circuitos elétricos equivalentes (CEE) utilizados nos ajustes dos dados de espectroscopia de impedância eletroquímica: (A) arranjo com duas constantes de tempo em cascata para os sete dias iniciais, (B) arranjo com três constantes de tempo adotado para 21, $28,35,41,59,62$ e 72 dias de imersão em $\mathrm{NaCl} 0,1 \mathrm{~mol}^{-L^{-1}}$ 
Figura 56: CEE e modelo proposto para o mecanismo de corrosão das superfícies das amostras após imersão em solução de $\mathrm{NaCl} 0,1$ mol..-1 ${ }^{-1}$ com tratamento T10, (A) 1 a 2 dias e (B) de 3 a 7 dias............

Figura 57: CEE e modelo proposto para o mecanismo de corrosão das superfícies após imersão em solução de $\mathrm{NaCl} 0,1 \mathrm{~mol} \cdot \mathrm{L}^{-1}$ de 1 a 7 dias das amostras com tratamento T10 10

Figura 58: CEE e modelo proposto para o mecanismo de corrosão das superfícies após imersão em solução de $\mathrm{NaCl} 0,1$ mol.L $\mathrm{L}^{-1}$ das amostras com tratamento T10_10_10, (A) 1 a 7 dias e (B) de 7 a 72 dias 


\section{Tabelas}

Tabela 1: Composição nominal (\% em massa) do aço SAE/AISI 1010 usado como substrato para eletrodeposição de zinco..............................................

Tabela 2: Reagentes, parâmetros usados na obtenção do banho de conversão, constituição dos tratamentos de conversão e nomenclatura..........

Tabela 3: Valores de pH das soluções de nitrato de cério hexahidratado, sulfato de sódio, nitrato de sódio, 2 butino-1,4 diol propoxilato, e da mistura destas soluções formando a solução de tratamento proposta...........................

Tabela 4: Valores de $\mathrm{pH}$ das soluções precursoras e da solução de conversão.

Tabela 5: Concentrações atômicas, picos, energias de ligação e fatores de ajuste obtidos por espectroscopia fotoeletrônica de raios X (XPS) para os tratamentos $\mathrm{T} 1, \mathrm{~T} 10$ e T20

Tabela 6: Concentrações atômicas, picos, energias de ligação e fatores de ajuste para elemento carbono, obtidas por espectroscopia fotoeletrônica de raios X (XPS) em função do tempo de sputtering (s), para o tratamento T10, 10 minutos em solução contendo Cério.

Tabela 7: Concentrações atômicas e fatores de ajuste para Zn2p, obtidas por espectroscopia fotoeletrônica de raios X (XPS) em função do tempo de sputtering (s), amostra com tratamento T10.

Tabela 8: Concentrações atômicas e fatores de ajuste para O1s, obtidas por espectroscopia fotoeletrônica de raios X (XPS) em função do tempo de sputtering (s), amostra com tratamento T10

Tabela 9: Concentrações atômicas e fatores de ajuste para Ce3d, obtidas por espectroscopia fotoeletrônica de raios X (XPS) em função do tempo de sputtering (s), amostra com tratamento T10

Tabela 10: Tempos de exposição em névoa salina para as amostras de zinco sem tratamento, cromatos, e os tratamentos investigados em função do tempo de imersão em solução contendo cério por diferentes tempos de imersão, tratamentos, T1, T10 e T20.

Tabela 11: Valores para elementos de circuito elétrico equivalente em função do tempo de imersão em 0,1M de $\mathrm{NaCl}$, para a amostra T10. 
Tabela 12. Picos, energias de ligação, fatores de ajuste (FWHM) e concentrações atômicas, obtidos por XPS, das amostras T10_1, T10_10 e T10_20.

Tabela 13: Concentrações atômicas, picos, energias de ligação e fatores de ajuste para elemento carbono, obtidas por XPS em função do tempo de sputtering (s), para as amostras T10_10, 10 minutos em solução de peróxido de hidrogênio.

Tabela 14: Concentrações atômicas, e ajustes para 01s, obtidas por XPS em função do tempo de "sputtering" (s), amostra com tratamento T10_10.

Tabela 15: Concentrações atômicas, picos, energias de ligação e fatores de ajuste para elemento zinco, obtidas por XPS em função do tempo de sputtering (s), para as amostras T10_10, 10 minutos em solução de peróxido de hidrogênio.

Tabela 16: Concentrações atômicas, picos, energias de ligação e fatores de ajuste para elemento cério, obtidas por XPS em função do tempo de sputtering (s), para as amostras T10_10, 10 minutos em solução de peróxido de hidrogênio.

Tabela 17: Tempos de exposição em névoa salina para aparecimento de produtos de corrosão na superfície das amostras de zinco, com camada de conversão de cromatos, e com os tratamentos investigados, T10_1, T10_10 e T10_20.

Tabela 18: Valores para elementos de circuito elétrico equivalente em função do tempo de imersão em 0,1M de $\mathrm{NaCl}$, para amostra T10_10.......

Tabela 19: Picos, energias de ligação, fator de ajuste (FWHM) e concentrações atômicas, obtidos por XPS, das amostras T10_10_1, T10_10_10 e T10_10_20.

Tabela 20: Concentrações atômicas e fatores de ajuste para C1s, obtidas por XPS em função do tempo de sputtering (s), amostra com tratamento T10_10_10.

Tabela 21: Concentrações atômicas e fatores de ajuste para O1s, obtidas por XPS em função do tempo de sputtering (s), amostra com tratamento T10_10_10..... 
Tabela 22: Concentrações atômicas e fatores de ajuste para Zn2p, obtidas por XPS em função do tempo de sputtering (s), amostra com tratamento T10_10_10.

Tabela 23: Concentrações atômicas e fatores de ajuste para Ce3d, obtidas por XPS em função do tempo de sputtering (s), amostra com tratamento T10_10_10.

Tabela 24: Concentrações atômicas e fatores de ajuste para Nb3d, obtidos por XPS em função do tempo de sputtering (s), tratamento T10_10_10

Tabela 25: Tempos de exposição em névoa salina para aparecimento de produtos de corrosão na superfície das amostras de zinco, com camada de conversão de cromatos, e com os tratamentos investigados, T10_10_1, T10_10_10 e T10_10_20.

Tabela 26: Valores para elementos de circuito elétrico equivalente em função do tempo de imersão (1 a 7 dias) em $0,1 \mathrm{M}$ de $\mathrm{NaCl}$, para amostra T10_10_10

Tabela 27: Valores para elementos de circuito elétrico equivalente em função do tempo de imersão $(7,14,21,28,35,41,59,62$ e 72 dias) em $0,1 \mathrm{~mol}$. $\mathrm{L}^{-1}$ de $\mathrm{NaCl}$, para amostra com tratamento T10_10_10.... 


\section{INTRODUÇÃO}

As sociedades são dependentes dos metais e estes são utilizados nos mais variados segmentos da vida em comunidade, que vão desde transportes, ferramentas e estruturas, onde são usadas grandes quantidades de ferro fundido e aço. A crescente utilização de metais não se restringe apenas ao aço, mas se estende a outros metais como alumínio, titânio e zircônio - metais da era espacial. A confecção e utilização de materiais metálicos, atualmente, é um parâmetro de medida para o avanço tecnológico de uma sociedade (WESTBROOK, 1986).

Dentre os setores que empregam aços de baixa liga, o setor automobilístico é líder, juntamente com o setor de produtos eletrodomésticos, denominado linha branca. Quando os números, apresentados em 2010 pelo setor metalúrgico, são somados aos números representados por produtos da linha branca, motocicletas, autopeças, ferroviários, rodoviários e agrícolas, tem-se $22 \%$ da utilização nacional de aço na forma de aço de baixa liga, com 4,54 milhões de toneladas. O consumo per capita destes materiais é um indicador direto de desenvolvimento econômico (ANFAVEA, 2013). Uma das causas de perda econômica por consumo em consequência de perdas das propriedades para as quais foi projetado é a corrosão.

A corrosão pode ser definida como sendo o resultado de uma reação química ou eletroquímica entre diferentes materiais e o ambiente em que se encontra levando à deterioração destes materiais com a perda de propriedades físicas (PANOSSIAN, 1993). A corrosão do aço é significativamente reduzida pelo uso de revestimentos que são anódicos em relação ao aço, promovendo proteção sacrificial, como é o caso dos revestimentos de zinco.

Um dos processos mais difundidos de deposição de zinco para proteção sacrificial do aço é o processo conhecido como eletrodeposição. Quando comparado a outros processos de deposição de zinco, a eletrodeposição produz revestimentos de melhor aspecto decorativo, devido ao zinco puro depositado apresentar boa aderência e ductilidade. 
Os revestimentos de zinco, depositados por processo eletrolítico atuam como proteção galvânica ativa ao aço e sua aplicação vem ocorrendo industrialmente há longo tempo (YADAV, 2004). A susceptibilidade à corrosão dos aços eletrozincados está diretamente relacionada com a uniformidade dos depósitos de zinco superficiais, a corrosão tendo início em regiões de menor espessura (e/ou defeitos). A variação da espessura pode ser controlada nos aços durante o processo de eletrodeposição, principalmente por utilizar taxa de corrente constante e tratamentos com aditivos niveladores. (GEDULD, 1975; SHORT, 1996; GIGANDET, 1997; ISHII, 1998).

Pesquisas mostram que o custo direto associado à corrosão é de aproximadamente US\$1,4 trilhão, ou 3,5\% do PIB mundial. Esses números refletem apenas o custo direto essencialmente com materiais, equipamentos $\mathrm{e}$ serviços envolvidos com a reparação, manutenção, substituição e não incluem danos ambientais, desperdício de recursos, perda de produção ou danos pessoais resultantes da corrosão (SCHMITT, 2009).

A eletrodeposição do zinco, embora diminua a cinética de corrosão, confere proteção temporária, a cinética pode ser ainda mais reduzida quando a superfície de zinco é modificada pela aplicação de revestimentos, sejam estes orgânicos, metálicos ou de conversão. Uma das formas mais empregadas para reduzir a velocidade de corrosão do aço eletrozincado é a utilização de tratamento de conversão com formação de cromatos, principalmente aqueles com cromo hexavalente. A importância e grande utilização das camadas de conversão com cromo hexavalente (CCC) se deve, principalmente, à sua capacidade de autorregenerarão ou self healing (MARTYAK, 1994; YAHAYA, 2009; STANKIEWICZ, 2013). Neste trabalho a modificação de superfície foi o método escolhido para a proteção contra a corrosão, feito por imersão em solução contendo precursores poliméricos.

Camadas de cromato têm como características principais apresentar boa aderência a filmes poliméricos (tintas) e resistência à oxidação atmosférica. No entanto, o cromo hexavalente é carcinogênico e tóxico e os resíduos gerados pelo processo de cromatização causam problemas ambientais (COHEN, 1993, LAMB, 2013). A utilização do $\mathrm{Cr}$ hexavalente $\left(\mathrm{Cr}^{6+}\right)$ vem sofrendo restrições cada vez 
maiores e alguns processos indenizatórios, com altos valores gastos pelas indústrias, juntamente com uma preocupação ambiental, o que têm acelerado buscas por novos materiais passivantes que não envolvam este íon (ZUCKERMAN, 2004; BARAL, 2002 e 2006).

A total substituição do cromo hexavalente nas camadas de conversão como forma de proteção à corrosão ainda depende de alguns fatores, entre os quais, a necessidade de que os novos tratamentos alternativos apresentem propriedades equivalentes e ou superiores às camadas de conversão de cromo hexavalente e de serem atóxicos (ALMEIDA, 1998).

Para a obtenção de revestimentos equivalentes aos cromatos, é necessário entender como o processo de autorregeneração ocorre, sendo essa uma das mais importantes propriedades deste tipo de revestimento. O processo de autocura pode ser resumido pelos seguintes eventos, a saber: (1) corrosão do metal (oxidação), (2) aumento de pH sobre a superfície metálica e redução do cromo hexavalente para cromo trivalente e subsequente precipitação na forma de hidróxido de Cr III, conforme indicado nas equações 1 e 2 (ZHANG, 2005).

$$
\begin{aligned}
& \mathrm{M} \rightarrow \mathrm{M}^{2+}+2 \mathrm{e}^{-} \\
& \mathrm{Cr}_{2} \mathrm{O}_{7}{ }^{2-}+14 \mathrm{H}^{+}+6 \mathrm{e}^{-} \rightarrow 2 \mathrm{Cr}^{3+}+7 \mathrm{H}_{2} \mathrm{O}
\end{aligned}
$$

Os estudos que relatam a busca de alternativas para as camadas de conversão de cromato foram intensificados pelas restrições e até mesmo proibição do uso de cromo hexavalente. Estas investigações começaram com os metais oxiânicos por apresentarem algumas características semelhantes ao cromo e menor toxicidade e, posteriormente, por elementos adjacentes na tabela periódica, como vanádio e manganês utilizados na forma de seus sais (BIESTEK, 1984; GIGANDET, 1997; ALMEIDA, 1998; XIA, 2000).

O presente trabalho visa desenvolver tratamentos de passivação de camada de zinco obtida por eletrodeposição que não foram ainda estudados, que não gerem resíduos tóxicos, e com potencialidade para substituição da camada de conversão de cromato. Esta é a contribuição original do presente trabalho. 


\subsection{Considerações Ambientais}

A atividade tecnológica na indústria de galvanoplastia, até muito recentemente, era exclusivamente dependente da capacidade, ou melhor, versatilidade dos íons cianetos empregados para solubilizar metais via complexação. A simplicidade na técnica de uso de íons cianetos, em galvanoplastia, representado pelo fácil controle e manutenção de processo, assim como baixo custo são os argumentos principais no largo emprego do mesmo (CABISTANI, 1994).

A constante alteração apresentada pela legislação ambiental em praticamente todo o mundo, com a criação de penalidades, em muitos casos, extremamente severas, vem elevando os custos relativos ao uso de cianetos. A necessidade de estações de tratamentos de resíduos e mesmo multas aplicadas em caso de acidentes no manuseio de cianetos alavancaram a busca por substituintes desta espécie química, principalmente para aplicação na indústria de galvanoplastia (LOWENHEIN, 1978).

As primeiras tentativas de substituição tiveram início na década de setenta e não foram bem sucedidas, o que levou à adoção de banhos com baixo teor de cianetos (low zinc cianate) ou LZC. Os banhos LZC contam com uma quantidade máxima entre 5 e $15 \mathrm{~g} . \mathrm{L}^{-1}$ de $\mathrm{NaCN}$, e os bons resultados no seu emprego levaram metade das indústrias americanas a usar banhos LZC na década de setenta (MURPHY, 1971; TORPY, 1980). Entre esses bons resultados, podemos citar $\mathrm{o}$ atendimento às restrições ambientais e produção de camadas com zinco uniforme, depósitos de espessura apreciáveis, sem corrosão branca em pontos de solda, custo reduzido, fácil controle químico da solução reacional. No entanto, com a utilização em larga escala, surgiram problemas, tais como, formação de bolhas superficiais e brilho reduzido (NATORSKY, 1992).

A correção destes problemas ocorreu com o uso de reagentes com maior grau de pureza. Estes ajustes tornaram os custos mais elevados e, em alguns casos, proibitivos. Os estudos avançaram e os banhos isentos de íons cianeto (NCZ) foram adotados. Estes banhos são formulados utilizando hidróxido de zinco ou óxido de zinco, hidróxido de sódio ou hidróxido de potássio e pequenas quantidades de aditivos niveladores e abrilhantadores (GEDULD, 1975). 
Vale ressaltar que este processo tem total dependência dos aditivos utilizados e que, embora seja funcional, o mecanismo reacional não foi totalmente compreendido. A busca por tratamentos pós-eletrodeposição que propiciem uma diminuição na cinética de corrosão da camada de zinco e, assim, confira maior longevidade a substratos metálicos e, ainda que sejam livres de cromo hexavalente, tem crescido nas últimas décadas.

Os trabalhos publicados na literatura (HINTON, 1992; MONTEMOR, 2002; ARAMAKI, 2002; TRABELSI, 2005; KOBAYASHI, 2006; HOSSEINI, 2007; PENG, 2009; HASSEN, 2008 e 2009) sobre os tratamentos à base de sais de cério têm mostrado resultados satisfatórios. Alguns pesquisadores relatam resultados superiores aos tratamentos de conversão (CCC) à base de cromo hexavalente, devido principalmente à formação de óxido e hidróxidos de cério com baixa solubilidade em meios corrosivos.

Banczek (BANCZEK, 2013), muito recentemente, relatou resultados promissores para o uso de nióbio como tratamento de conversão para aços de baixa liga e outros substratos metálicos, principalmente devido à formação de óxidos de alta estabilidade, ligados ao substrato, após o tratamento de conversão. O emprego de fontes precursoras de nióbio e as justificativas para sua utilização se baseiam no fato do Brasil possuir a maior reserva mundial deste minério (BANCZEK, 2008).

\subsection{Justificativa para o tema}

\subsubsection{Emprego do Cério}

O elemento cério foi descoberto simultaneamente por Jakob Berzelius e Wilhelm Hisingerem sendo, em seguida, constatado que o cério, que atestava ser um novo elemento, era de fato uma mistura de cério, lantânio e neodímio. Separado e confirmado como novo elemento, este foi nomeado Cério, inspirado em um recém-descoberto asteroide, Ceres, e o símbolo adotado para este elemento foi Ce.

O Cério possui número atômico 58 (58 prótons e 58 elétrons) e massa atômica 140,1 u. Elemento da classe dos metais de transição interna (terra raras, 
lantanídeos) à temperatura ambiente é sólido, sendo encontrado principalmente, como minerais monazita (Ce, La, Th, Nd, Y) $\mathrm{PO}_{4}$ e bastnasita (Ce, La, Y) $\mathrm{CO}_{3} \mathrm{~F}$. Estas são as duas mais importantes fontes de cério (YOST, 1947; VICKERY, 1953).

O cério é o mais abundante entre os elementos de terras raras, quase sempre presente em areias monazíticas, correspondendo à aproximadamente $0,0046 \%$ da crosta terrestre. Os mais importantes depósitos de areias monazíticas mundiais estão nos Estados Unidos (Idaho - Montana e Flórida), Brasil (Espírito Santo e Catalão-Ouvidor), Austrália, África do Sul e Índia. As plantas de mineração deste elemento são as mesmas plantas que obtêm nióbio. Assim, estes dois elementos são obtidos em processos paralelos, sem necessidade de uma estrutura física diferenciada (MCCARTHY, 1980 e1982).

Quando na forma de sulfato, o cério é um forte agente oxidante usado em análises químicas volumétricas. Devido à distribuição eletrônica no subnível $4 \mathrm{f}$ e de outros orbitais mais externos, o cério exibe características químicas interessantes e importantes com larga aplicação em transformações de substratos orgânicos. Por isso, seu óxido é usado como catalisador em fornos autolimpantes na indústria do petróleo. Na forma de cloreto $\left(\mathrm{CeCl}_{3}\right)$ é usado para facilitar reações em grupos carbonilas, em química orgânica. Outros compostos de cério trivalente de fácil obtenção são o carbonato de cério III $\left(\mathrm{Ce}_{2}\left(\mathrm{CO}_{3}\right)_{3}\right)$, o fluoreto de cério III $\left(\mathrm{CeF}_{3}\right)$, e o sulfato cérico $\mathrm{Ce}_{2}\left(\mathrm{SO}_{4}\right)_{3}$. O cério, como todos os metais de terras raras, apresenta toxicidade de moderada a baixa, e atóxicos na forma de óxidos (KILBOURN, 1986, 1992; ABRÃO, 1994).

O cério pode reagir com o zinco devido à sua alta afinidade com este elemento, e as reações com este metal são exotérmicas. Entre as formas mais comuns de óxido de cério formados estão, o óxido de cério III e óxido de cério IV. Reagentes de cério foram utilizados com sucesso na reação de orgânicos (cetonas), fornecendo sais carboxilatos (BARROS FILHO, 2000). 


\subsubsection{Emprego do Nióbio}

O nióbio foi descoberto no começo do século XIX pelo britânico Charles Hatchett e o nome adotado foi nióbio, homenagem à deusa Niobe. Está entre as substâncias de mais baixa concentração na crosta terrestre, na proporção de 24 partes por milhão. Seu símbolo químico é $\mathrm{Nb}$ com número atômico 41 na tabela periódica dos elementos químicos. Classificado como metal de transição, tem densidade de $8,57 \mathrm{~g} / \mathrm{cm}^{3}$ e, em condições normais de temperatura e pressão, encontra-se no estado sólido com ponto de fusão de $2468{ }^{\circ} \mathrm{C}$ e ponto de ebulição $4744{ }^{\circ} \mathrm{C}$ (LABINGER, 1978).

O nióbio possui grande afinidade geoquímica com ao elemento tântalo, sendo encontrados juntos na maioria das rochas e dos minerais em que ocorrem. $\mathrm{Na}$ forma mineral, nióbio e tântalo, apresentam mais de 90 espécies conhecidas como minerais de mais alta concentração de nióbio, das quais se destacam as composições químicas columbita tantalita $(\mathrm{Fe}, \mathrm{Mn})\left(\mathrm{Nb}, \mathrm{Ta}_{2}\right) \mathrm{O}_{6}$, com teor máximo de $76 \%$ de $\mathrm{Nb}_{2} \mathrm{O}_{5}$; e o pirocloro $\left(\mathrm{Na}_{3}, \mathrm{Ca}\right)_{2}(\mathrm{Nb}, \mathrm{Ti})(\mathrm{O}, \mathrm{F})_{7}$, com teor máximo de $71 \%$ de $\mathrm{Nb}_{2} \mathrm{O}_{5}$; (KOROTKOV, 2006).

Até o final dos anos 1950, o nióbio era obtido como subproduto do tratamento das columbitas e tantalitas, minerais pouco abundantes e, empregado principalmente para a obtenção de ligas metálicas, particularmente aços de alta resistência mecânica e térmica. $O$ fato de ser um subproduto e ter um uso direcional implica em elevado custo e uso restrito a um tipo de aço inoxidável e a algumas superligas (LABINGER, 1978). Com as descobertas de significativas reservas de pirocloro no Brasil e no Canadá e com melhoras acentuadas na prospecção do nióbio, houve uma transformação radical nos custos e viabilização de nióbio e cério para aplicações diversas. Atualmente, as três maiores reservas exploradas de nióbio no mundo estão localizadas no Brasil, em Araxá, Catalão e Ouvidor (SYCH, 1973; USHIKUBO, 2000).

O nióbio, o titânio e o vanádio são alguns dos elementos utilizados na fabricação dos aços micro ligados, principalmente devido a sua alta afinidade com o carbono. Para o elemento nióbio, as adições típicas são próximas de 0,04\% em massa. A vantagem do nióbio em relação ao vanádio e ao titânio é que ele confere maior resistência à corrosão quando usado como elemento de liga em 
aços e seu uso em conjunto com os outros elementos possibilita sinergismo à liga formada. A associação de nióbio e titânio, por exemplo, na liga de alta resistência é muito utilizada e este confere alta qualidade ao produto final (GUPTA, 1981).

O nióbio é utilizado também na fabricação de aços inoxidáveis, particularmente ferríticos, sendo responsável por $10 \%$ do consumo mundial de nióbio. A aplicação destas ligas é mais comum na produção de escapamentos automotivos, com a adição de nióbio garantindo melhor desempenho e durabilidade nas condições de trabalho em temperaturas elevadas (SEN, 1982, 2004).

O uso do nióbio em ferros fundidos é mais recente, utilizado, por exemplo, em anéis de segmento e camisas de cilindros nos motores automotivos. O Brasil é o maior produtor mundial de nióbio, com aproximadamente 98\% do total mundial, seguido pelo Canadá e Austrália, que respondem pelo percentual restante e oxalato de nióbio amoniacal (ANO), que possui cerca de $30 \%$ do peso em nióbio, é um subproduto da mineração de nióbio (SAKHAROV, 1974, 1981).

O presente trabalho visa o desenvolvimento de tecnologia limpa para o setor metalúrgico, representada pela obtenção de revestimentos que confiram proteção contra a corrosão de aço eletrozincado e que promovam aderência às camadas de revestimento orgânico a serem posteriormente aplicadas.

Este estudo justifica-se ainda pelas grandes reservas nacionais de compostos de nióbio e, principalmente pela sua compatibilidade ambiental, relacionada à baixa toxicidade das substâncias utilizadas para a obtenção de seus compostos. O nióbio, neste trabalho, foi utilizado na forma de um complexo de oxalato, mais especificamente, oxalato de nióbio amoniacal monohidratado (ANO) e embora pouco estudado algumas características deste oxalato são encontradas na literatura.

O complexo amoniacal de Nióbio (ANO) consiste num reagente solúvel em água, cuja solubilidade está na faixa de 60 a 160 gramas de nióbio por litro e é utilizado como uma fonte do elemento químico Nióbio (NARENDAR, 1997). Sua fórmula química geral é $\mathrm{NH}_{4} \mathrm{H}_{2}\left[\mathrm{NbO}\left(\mathrm{C}_{2} \mathrm{O}_{4}\right)_{3}\right]$. $\mathrm{H}_{2} \mathrm{O}$. É um complexo de alta pureza, estrutura cristalina monoclínica, teor de $\mathrm{Nb}$ de $30 \%$ em massa, adequado à 
síntese de materiais funcionalizados, tais como cerâmicas, catalisadores, óxidos de nióbio de alta pureza, filmes finos e cristais, de escala macro e nanométrica. Tem sido usado como fonte precursora de nióbio sendo adicionado na composição de banhos para tratamentos por imersão como promotor ou dopante. Este complexo ainda é pouco estudado (BARROS FILHO, 2000). 


\section{OBJETIVOS}

\subsection{Objetivo geral}

O objetivo do presente trabalho foi o desenvolvimento de revestimentos orgânicos com incorporação de cério e nióbio para proteção contra a corrosão do aço eletrozincado visando a substituição de camadas de conversão de cromato à base de íons de cromo hexavalente e avaliar a potencialidade destes novos tratamentos alternativos.

\subsection{Objetivos específicos}

Os objetivos específicos desta tese foram:

(1) Avaliar a viabilidade de utilização de aditivo orgânico comercial 2 butino-1,4diol propoxilato como fonte precursora para a formação de filmes orgânicos sobre zinco.

(2) Avaliar o efeito da adição de nitrato de cério à solução de 2 butino-1,4 diol propoxilato na resistência a corrosão do substrato de zinco.

(3) Avaliar a influência do uso de oxalato de nióbio amoniacal quando associado a 2 butino-1,4 diol propoxilato na formação de filme contendo nióbio e o efeito deste filme na resistência a corrosão do zinco.

(4) Comparar a resistência à corrosão das superfícies de aço eletrozincado com os filmes obtidos pelos tratamentos propostos neste estudo, com as superfícies das camadas de conversão de cromato à base de íons de cromo hexavalente. 


\section{REVISÃO DA LITERATURA}

\subsection{Revestimentos de zinco}

O zinco é amplamente usado como um revestimento protetor contra a corrosão do aço carbono. A cada ano, mais de 40 milhões de toneladas de aço são revestidos com zinco ou transformados em ligas de zinco e mais de 2,2 milhões de toneladas de zinco são usados em todo o mundo para diversos tipos de revestimentos (PORTER, 1988, 1994). Como o zinco é mais eletronegativo que o ferro, fornece proteção galvânica ao substrato de aço (NEVISON, 1987).

Os revestimentos de zinco podem ser obtidos por diferentes processos de revestimento, entre estes: galvanização por imersão a quente ou hot-dip, eletrodeposição, pulverização e processo mecânico. A galvanização por imersão a quente tem algumas vantagens frente aos demais métodos de revestimento com camadas de zinco, incluindo a capacidade para revestir áreas rebaixadas. No entanto, este processo é limitado pela necessidade de temperaturas elevadas, até o ponto de fusão dos elementos de liga do zinco, o que pode levar a alteração de propriedades do aço durante o processo de revestimento (NATORSKY, 1992).

A eletrodeposição, por sua vez, tem algumas vantagens especiais, tais como menor gasto energético, uma vez que pode ser realizada à temperatura ambiente, possibilidade de ajuste de parâmetros do processo para obtenção de revestimentos com espessura desejada e grande uniformidade dos revestimentos, geralmente com superfícies homogêneas. Por isso os revestimentos de zinco obtidos pelo processo de eletrodeposição são considerados mais econômicos e eficazes de proteção contra a corrosão de aço carbono (SHORT, 1996).

A camada de óxido de zinco formada por exposição ao ar evolui para a forma de hidróxido quando exposto ao intemperismo (umidade ou chuva). Durante o processo de secagem, o hidróxido de zinco reage com o dióxido de carbono na atmosfera, sendo convertido a uma fina, compacta e aderente camada de carbonato básico, que fornece proteção ao interpor uma barreira entre o substrato e o meio corrosivo. Quando as superfícies de zinco revestidas são submetidas a danos mecânicos, a ponto de expor o aço aos agentes corrosivos, o zinco é 
lentamente corroído, enquanto o aço permanece inalterado (NEUFELD, 2002).

As camadas de zinco possuem boa tolerância a vários produtos químicos em uma faixa de pH de 4 a 12, e a corrosão destas é influenciada por diversos fatores, tais como: umidade, temperatura e presença de diferentes espécies químicas (poluentes do ar). Estes fatores estão diretamente relacionados ao início do crescimento do filme de proteção, geralmente representado pelo próprio produto de corrosão, neste caso, o óxido de zinco.

Caso a exposição continue por longos períodos de tempo, maior será a quantidade de água adsorvida na superfície de zinco, o que permite mobilidade iônica e, assim, uma película fina de $\mathrm{Zn}(\mathrm{OH})_{2}$ se forma, segundo as equações:

$$
\begin{array}{ll}
\mathrm{Zn}_{(\mathrm{s})} \rightarrow \mathrm{Zn}^{2+}+2 \mathrm{e}^{-} & \\
\mathrm{O}_{2}+4 \mathrm{H}_{3} \mathrm{O}^{+}+4 \mathrm{e}^{-} \rightarrow 6 \mathrm{H}_{2} \mathrm{O} & \text { (meio ácido) } \\
2 \mathrm{H}_{3} \mathrm{O}^{+}+2 \mathrm{e}^{-} \rightarrow 2 \mathrm{H}_{2} \mathrm{O}+\mathrm{H}_{2} & \text { (meio ácido) } \\
\mathrm{O}_{2}+2 \mathrm{H}_{2} \mathrm{O}+4 \mathrm{e}^{-} \rightarrow 4 \mathrm{OH}^{-} & \text {(meio neutro aerado) } \\
\mathrm{Zn}^{2+}+2 \mathrm{OH}^{-} \rightarrow \mathrm{Zn}(\mathrm{OH})_{2} &
\end{array}
$$

O produto de corrosão, $\mathrm{Zn}(\mathrm{OH})_{2}$, sofre sucessivas reações, dentre as quais se pode citar a reação com $\mathrm{CO}_{2}$ dissolvido na água, formando um produto de menor solubilidade em meio básico $\left(\mathrm{Zn}_{5}\left(\mathrm{CO}_{3}\right)_{2}(\mathrm{OH})_{6}\right.$, conhecido como hidrozincato (ODNEVALL, 1995), segundo equação abaixo:

$$
\begin{aligned}
& \mathrm{CO}_{2}(\mathrm{~g})+\mathrm{H}_{2} \mathrm{O} \rightarrow \mathrm{H}_{2} \mathrm{CO}_{3} \rightarrow 2 \mathrm{H}^{+}+\mathrm{CO}_{3} 2- \\
& \mathrm{Zn}(\mathrm{OH})_{2}(\mathrm{~s})+4 \mathrm{Zn}^{+2}+4 \mathrm{OH}^{-}+2 \mathrm{CO}_{3}{ }^{2-} \rightarrow \mathrm{Zn}_{5}\left(\mathrm{CO}_{3}\right)_{2}(\mathrm{OH})_{6}
\end{aligned}
$$

Este produto é metaestável, sofrendo modificações, de acordo com o ambiente em que está presente. Em ambiente marinho (presença de $\mathrm{NaCl}$ ), o produto formado é o cloro hidroxisulfato de zinco, $\mathrm{NaZn}{ }_{4} \mathrm{Cl}(\mathrm{OH})_{6} \mathrm{SO}_{4} \cdot 6 \mathrm{H}_{2} \mathrm{O}$ (ODNEVALL, 1995). 
Quando o zinco é exposto a meios aquosos, ocorre a solubilização do zinco metálico, íons de zinco vão para a solução e a redução do oxigênio dissolvido ocorre na superfície do zinco metálico. Uma vez que o oxigênio dissolvido no meio vai sendo esgotado, e não há difusão suficiente de oxigênio para a superfície a fim de manter a reação catódica, a reação catódica dominante será a evolução de hidrogênio, com os íons hidrogênio sendo reduzidos a gás hidrogênio (MORGAN, 1985).

A corrosão do zinco avança de forma heterogênea em condições cíclicas (molhamento e secagem) na presença de íons cloreto, devido, provavelmente, à deposição heterogênea de sais cloreto na superfície do revestimento durante os períodos de secagem. A corrosão evolui dos sítios ativos até atingir a interface entre o revestimento de zinco e o aço do substrato e, quando isto ocorre, há diminuição na resistência de poros (ARAMAKI, 2001). Esta redução ocorre porque, quando no local ativo a dissolução anódica de zinco ocorre com taxas elevadas, as reações se voltam para o cátodo pela exposição direta do ferro ao meio. Uma indicação da diminuição da resistência no poro é a corrosão vermelha com a formação de óxidos, hidróxidos, cloretos e carbonatos de ferro (YADAV, 2004).

Com o tempo de exposição ao meio corrosivo, ocorre a formação de diversos produtos de corrosão em diferentes estágios e, dependendo de suas solubilidades, os precipitados promovem proteção do substrato por interpor uma barreira entre este e a solução corrosiva (BYOUNG, 2010). Os principais produtos de corrosão formados são dependentes do tipo de meio ao qual são expostos. Por exemplo, em meios aquosos contendo cloreto, a Simonkolleita, de fórmula química geral $\mathrm{Zn}_{5} \mathrm{Cl}_{2}(\mathrm{OH}) \cdot 8 \mathrm{H}_{2} \mathrm{O}$, é o principal produto formado quando exposto por longos períodos de tempo, enquanto, para atmosferas isentas de cloreto, o $\mathrm{Zn}_{5}\left(\mathrm{CO}_{3}\right)_{2}(\mathrm{OH})_{6}$ hidrozincato é principalmente formado (ODNEVALL, 1995).

Várias explicações têm sido propostas para a inibição da corrosão das camadas de zinco pela presença da Simonkolleita (KEDDAM, 1992; AMADEH, 2002; VOLOVITCH, 2010; CHAVAN, 2013). Estas consideram o fato que quanto maior a quantidade desta nos produtos de corrosão, maior a resistência à corrosão e maior o efeito de barreira parcial à difusão de oxigênio, devido à sua 
baixa solubilidade. O transporte de massa intervém no mecanismo de corrosão do sistema formado pelo meio corrosivo, tanto na fase líquida, como da camada de produtos de corrosão que cobre a superfície metálica. Para aumentar a durabilidade destas camadas são realizados tratamentos de passivação (SHREEPATHI, 2010; TAOUIL, 2012; ROSCHMANN, 2013), entre estes, a utilização de camadas de conversão de cromato, que contêm cromo hexavalente (TOMACHUK, 2010; ROSALBINO, 2011; MOUANGA, 2013).

\subsection{Tratamentos de proteção sobre camada de zinco}

\subsubsection{Camadas de conversão à base de íons de cromo hexavalente}

As camadas de conversão, também conhecidas por revestimentos de conversão, são assim denominadas devido à forma como são obtidas. Neste tipo de processo, ocorre interação da superfície do metal com a solução de tratamento, geralmente uma solução corrosiva, que ataca o substrato metálico, convertendo-o a um revestimento obtido por precipitação ou deposição dos produtos dessa interação entre o metal e espécies presentes na solução de conversão (THOMPSON, 1983 e 1994).

O tratamento de conversão resulta na formação de camada firmemente ligada ao substrato metálico, seja por adsorção física ou química, de baixa solubilidade e com propriedades de isolamento elétrico. Os revestimentos de conversão podem ser obtidos por processos que empregam corrente elétrica como fonte da reação, ou não. Alguns processos que não fazem uso de corrente aplicada externamente, se baseiam no fato de que a energia entre a superfície metálica e o banho de conversão é suficiente para que a reação ocorra espontaneamente (WERNICK, 1987).

Os tratamentos de conversão mais utilizados para aço eletrozincado são os que utilizam soluções contendo ácido crômico. Estes causam a formação de camadas de conversão de cromato com íons de cromo hexavalente (CCC). O emprego deste tipo de tratamento é muito difundido por promover resistência à corrosão, conferir boa aderência a tintas e, principalmente, devido ao seu mecanismo de autocura (self-healing). Sua aplicação se intensificou durante a 
segunda guerra mundial. No entanto, mais recentemente, seu uso tem sido restringido devido às suas propriedades carcinogênicas (JUDAH, 2014).

Um dos processos mais utilizados para formação de camadas de conversão de cromato consiste nas seguintes etapas:

a) preparação da superfície (limpeza por desengraxe);

b) enxágue em água;

c) imersão em banho de cromatização;

d) enxágue em água corrente;

e) tingimento do revestimento produzido (se necessário) e

f) lavagem em água corrente (MONTEMOR, 2001).

O banho de cromatização geralmente é constituído por mistura de dicromato de sódio $\left(\mathrm{Na}_{2} \mathrm{Cr}_{2} \mathrm{O}_{7}\right)$ e ácido sulfúrico $\left(\mathrm{H}_{2} \mathrm{SO}_{4}\right)$ para ajuste de $\mathrm{pH}$ entre 1,2 e 2. O tratamento por imersão é feito em temperatura ambiente e os tempos de imersão podem variar, sendo diretamente proporcional à espessura da camada de conversão de cromato (FLEISCHANDERL, 2012).

Camadas mais espessas (tempos prolongados de imersão) apresentam maior número de trincas e de maior extensão em função do tempo de exposição do substrato, tornando a superfície mais suscetível à corrosão localizada (MARTYAK, 1994).

O comprimento e largura das fendas, por unidade de área, aumentam com o aumento do tempo de imersão e, isto ocorre provavelmente, devido ao aumento na tensão de tração com o aumento na espessura dos revestimentos. (ZHANG, 2005; HOSSEINI, 2007). A Figura 1 mostra uma representação esquemática do processo de autorregeneração (self healing) que ocorre em superfícies de aço eletrozincado com camadas de cromato em três etapas, adaptado de Hughes, (HUGHES, 2010). 

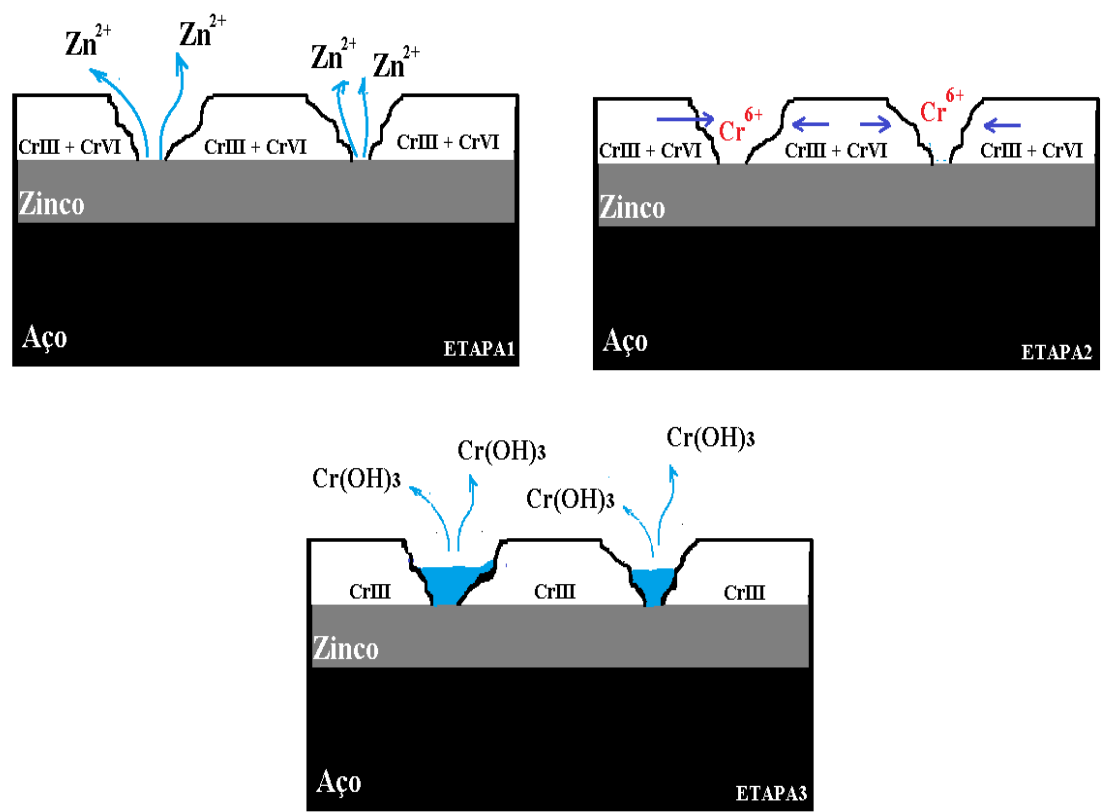

Figura 1: Representação esquemática do processo de self healing em trinca ou poro na superfície de aço eletrozincado com camadas de cromato. (Adaptado de Hughes, (HUGHES, 2010)).

O processo de cromatização, que ocorre em três etapas, tem início com a corrosão do metal (oxidação), seguido por aumento de pH sobre a superfície metálica, o que ocasiona reações de redução nas regiões catódicas, e, finalmente pela precipitação de uma camada. Quando o revestimento de zinco entra em contato com o banho de cromatização, ocorre a oxidação do metal (eq.9) e, ao mesmo tempo redução do cromato (eq.10), a formação de um filme gelatinoso (hidróxido de cromo III), com a camada de conversão atingindo espessura limite, segundo as equações 9, 10 e 11 (ZHANG, 2005).

$$
\begin{aligned}
& \mathrm{Zn} \rightarrow \mathrm{Zn}^{2+}+2 \mathrm{e}^{-} \\
& \mathrm{Cr}_{2} \mathrm{O}_{7}^{2-}+14 \mathrm{H}^{+}+6 \mathrm{e}^{-} \rightarrow 2 \mathrm{Cr}^{3+}+7 \mathrm{H}_{2} \mathrm{O} \\
& \mathrm{Cr}^{3+}+3 \mathrm{OH}^{-} \rightarrow \mathrm{Cr}(\mathrm{OH})_{3}
\end{aligned}
$$

A solubilidade dos hidróxidos de cromo trivalente é cerca de 1000 vezes menor que a solubilidade dos hidróxidos de zinco o que leva a formação preferencial de $\mathrm{Cr}(\mathrm{OH})_{3}$ e proteção ocorre por camada barreira (ARAMAKI, 2002). 
A formação de cromato como revestimento envolve a oxidação da superfície do metal e redução de cromo hexavalente ao estado trivalente. As reações catódicas irão levar a um aumento de $\mathrm{pH}$ local pelo consumo de $\mathrm{H}^{+}$, na interface entre solução e metal, até um valor que propicia a precipitação do cromo trivalente na forma de hidróxido de cromo (ZHANG, 1996).

As representações esquemáticas para a precipitação do Cromo trivalente na forma de hidróxido e da estrutura mista dos óxidos de cromo tri e hexavalente é mostrada nas Figuras 2 e 3.

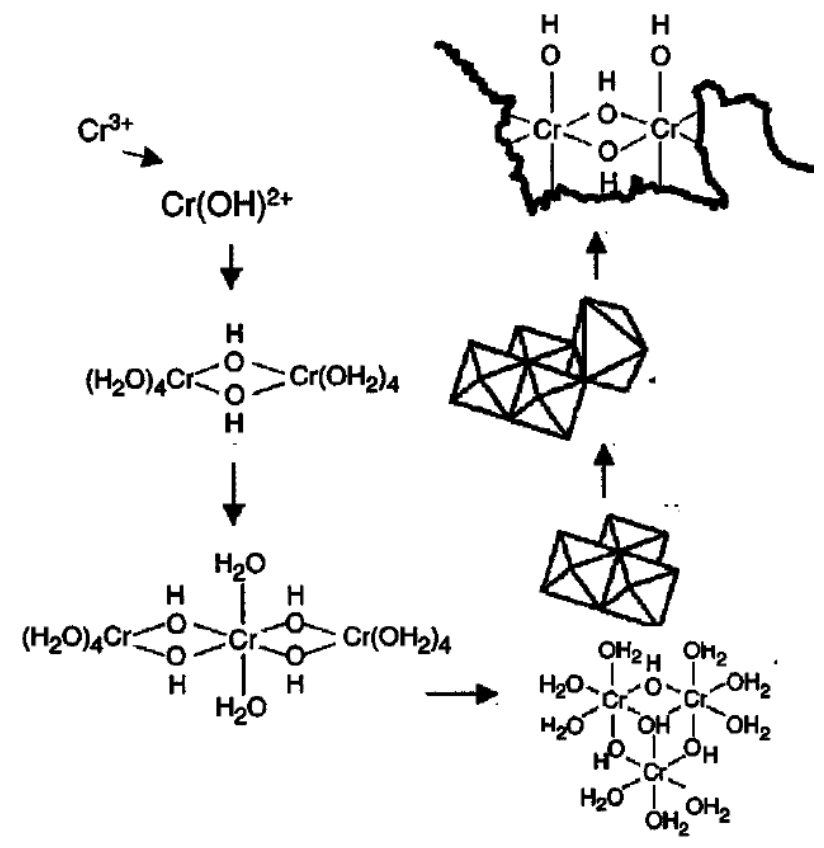

Figura 2: Representação esquemática da formação do $\mathrm{Cr}(\mathrm{OH})_{3}$ nas regiões de defeito no processo de autocura (ZHANG, 1996).

As reações para a formação de filmes a partir da solução de dicromato em meio ácido ilustram a formação do hidróxido de Cromo trivalente e o produto com Cromo hexavalente adsorvido nos defeitos superficiais em um processo de autocura. 


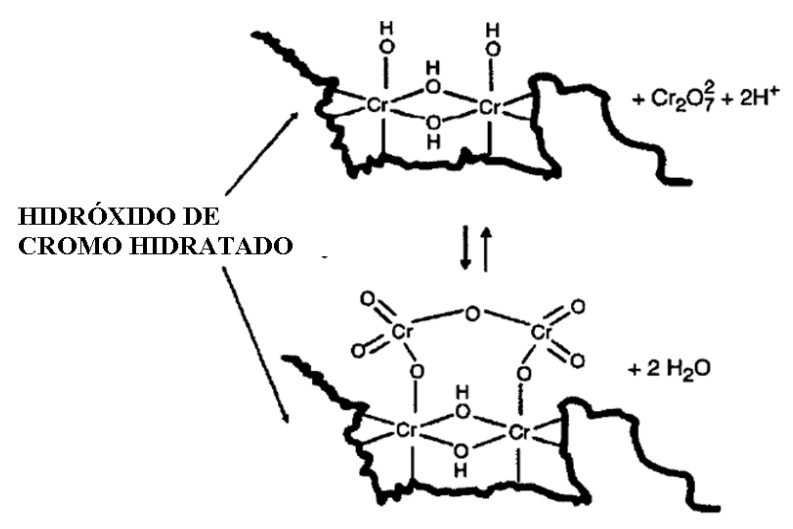

Figura 3: Representação esquemática de um produto misto de óxido de cromo trivalente e cromo hexavalente adsorvido ao substrato de aço galvanizado (ZHANG, 1996).

A adsorção das espécies de óxi-hidróxido de cromo ao substrato metálico é suficientemente intensa, de forma que o cromo hexavalente permanece adsorvido, mesmo após lavagem e secagem do produto (GIGANDET, 1997). As equações abaixo ilustram a interação entre a superfície do zinco e o ácido crômico.

$$
\begin{aligned}
& \mathrm{Zn}^{0}+2 \mathrm{HCr}_{2} \mathrm{O}_{7}^{-}+2 \mathrm{H}^{+} \rightarrow \mathrm{Zn}^{2+}+2 \mathrm{HCr}_{2} \mathrm{O}^{7-}+\mathrm{H}_{2} \\
& \mathrm{HCr}_{2} \mathrm{O}_{7}^{-}+3 \mathrm{H}_{2} \rightarrow 2 \mathrm{Cr}(\mathrm{OH})_{3}+\mathrm{OH}^{-} \\
& \mathrm{HCr}_{2} \mathrm{O}_{7}^{-}+\mathrm{H}_{2} \mathrm{O} \rightarrow 2 \mathrm{CrO}_{4}^{2-}+3 \mathrm{H}^{+} \\
& 2 \mathrm{Cr}(\mathrm{OH})_{3}+\mathrm{CrO}_{4}{ }^{2-}+2 \mathrm{H}^{+} \rightarrow \mathrm{Cr}(\mathrm{OH})_{3}+\mathrm{Cr}(\mathrm{OH}) \mathrm{CrO}_{4}+2 \mathrm{H}_{2} \mathrm{O}
\end{aligned}
$$

Para a obtenção das camadas de cromato, são importantes alguns fatores, tais como $\mathrm{pH}$, temperatura, tempo de imersão, grau de agitação, lavagem e temperatura de secagem. Dentre estes fatores, o pH é o mais importante na cromatização de peças galvanizadas e este deve estar entre 1 e 4 . Como as reações entre o metal e a solução aumentam o pH local, quanto mais ácido o meio, maior será o ataque ao substrato e maior deposição do filme protetor (RAMANAUSKAS, 2001).

A utilização deste processo se deve ao fato de retardar a cinética de corrosão do zinco, conferindo estabilidade superficial. Este tratamento de 
proteção ocorre após a etapa final da eletrodeposição, ocasiona a conversão da superfície metálica em cromato do metal, ou camada de conversão (ALMEIDA, 1998).

Os fatores que interferem na proteção contra a corrosão pelas camadas de conversão são: alto grau de isolamento, solubilidade dos compostos de cromo hexavalente, o que promove a inibição em áreas descontínuas do filme, e o mecanismo de autorregeneração ou self healing, com a evolução de cromatos emergentes, a partir da superfície próxima ao local de defeito (MONTEMOR, 2001, 2002).

Outra explicação oferecida para a proteção conferida pelos revestimentos de cromato é a presença de moléculas polares adsorvidas nestas soluções. As espécies adsorvidas formam uma película com cargas positivas (dipolo) na superfície, levando o potencial eletroquímico do substrato a valores mais positivos (ZHAO, 1998 e 2001), o que promove a passivação da superfície. A ação protetora contra a corrosão de revestimentos de cromato, todavia, aparentemente envolve principalmente a inibição da reação catódica (ZHANG, 2005).

O cromo hexavalente presente nos resíduos gerados pelo processo de cromatização é carcinogênico e tóxico, gerando problemas ambientais (HAGANS, 1994). Portanto, a utilização de tratamentos com cromo hexavalente vem sofrendo restrições cada vez maiores. Alguns processos indenizatórios ocorreram e se tornaram famosos, como o caso da Pacific Gas \& Electric (PG\&E). Estas restrições têm acelerado buscas por novos passivantes para camadas de zinco (EGILMAN, 2007).

Nos EUA, a agência de proteção ambiental EPA (Environmental Protection Agency) é o principal órgão regulador do uso de cromatos e, juntamente com a União Européia, tem se manifestado por meios de suas diretivas, nas quais a utilização de produtos perigosos, entre eles o cromo hexavalente, nos processos de fabricação de produtos diversos, é restringida (BARAL, 2002).

Os produtos de redução do cromo hexavalente - radicais livres, cromo hexavalente e pentavalente, parecem ser os responsáveis pelos efeitos carcinogênicos observados. A interação destes produtos com o DNA pode 
resultar em danos estruturais e funcionais do mesmo, o que acarreta em defeitos celulares, como quebra de DNA e aberrações cromossômicas (BARRY, 2013).

Os danos funcionais incluem sequestro do DNA e RNA polimerase, mutagênese e alteração da expressão gênica. Pode também interferir na replicação e transcrição do DNA ou, ainda, promover/inibir a expressão de genes regulatórios celulares. Embora muitos destes mecanismos ainda não estejam totalmente elucidados, sabe-se que o efeito cancerígeno do cromo hexavalente está associado ao estresse oxidativo da ligação cruzada do DNA-DNA e da inibição da transcrição (SILVA, 2001 e 2009).

As alternativas às camadas de cromato, todavia têm que preencher alguns requisitos, particularmente a de apresentarem propriedades de proteção conta a corrosão equivalentes às dos revestimentos de conversão de cromo hexavalente em eletrozincados, para se firmarem como realidades. Os processos para obtenção de revestimentos alternativos aos cromatos tiveram início com metais oxiânicos que apresentam características semelhantes ao cromo por pertencerem ao mesmo grupo químico, como molibdênio e tungstênio (STANKIEWICZ, 2013) e, posteriormente, se estenderam aos elementos adjacentes na tabela periódica, como vanádio e manganês, atualmente os estudos tem se intensificado buscando respostas quanto a sistemas mistos de camadas orgânicas que contenham estes elementos (HINTON, 1992; ZHANG, 2005).

Estes elementos são empregados na forma de sais dos seus compostos e, em alguns casos, como o dos molibdatos, foram mais estudados por já apresentarem atoxicidade e por reduzirem a susceptibilidade dos aços inoxidáveis à corrosão por pite. Mesmo com estas características favoráveis, os estudos iniciais resultaram em superfícies que apresentaram desempenho anticorrosivo inferior às das camadas de cromato (ARAMAKI, 2001).

Os materiais que empregam terras raras e organosilanos também têm sido investigados e, em alguns casos, apresentam resultados satisfatórios (MONTEMOR, 2002). No entanto, o emprego de uma destas alternativas como definitiva está ainda distante, pois, se as propriedades anticorrosivas são comparáveis às das camadas cromadas, outros fatores ainda são insatisfatórios, 
tais como aderência, propriedades decorativas, e razão custo/benefício. Pode-se afirmar que as opções estudadas são parcialmente viáveis, sendo necessárias pesquisas adicionais para uma solução econômica e ambientalmente viável (PENG, 2009).

\subsubsection{Revestimentos à base de cério}

Com as restrições ao uso de cromo hexavalente se tornando cada vez maiores nas últimas décadas, as pesquisas em busca de tratamentos equivalentes se intensificaram. Esta busca teve como referência a tabela periódica, onde as primeiras alternativas testadas partiram de sais de elementos da família do cromo, tais como molibdatos e tungstatos (ALMEIDA, 1998).

A continuidade destes estudos se estendeu a elementos com propriedades similares às dos elementos da família do cromo, como manganatos, vanadatos, niobatos, titanatos e sais de zircônio. A maioria das pesquisas iniciais alcançou algumas propriedades equivalentes, mas nunca todas as propriedades apresentadas pelas camadas de conversão de cromatos (CCC) (ARAMAKI, 2001). As pesquisas se estenderam e passaram a utilizar tratamentos associados (somatória de dois ou mais íons substituintes) e com elementos de outros grupos (HINTON, 1992).

São muitos os tratamentos alternativos testados como possíveis substituintes para o cromo hexavalente. Estes tratamentos podem ser preparados também da combinação de propriedades e de alguns sais que vão de fosfatos, molibdatos, tungstatos, vanadatos, permanganatos, niobatos, incluindo substâncias como sais de cobalto, zircônio, titânio, sais de terras raras, até revestimentos orgânicos (MONTEMOR, 2002).

Os recentes avanços na síntese de nano compósitos (nano materiais) permitiram uma via para pesquisas de tratamentos de substituição às CCC em que diferentes sais (precursores iônicos), são incorporados e testados como revestimentos para substratos metálicos (HINTON, 1992), com tratamentos mostrando resultados promissores (SCHOLES, 2006). 
Tratamentos à base de sais de terras raras têm se mostrado alternativas promissoras quanto à substituição de cromo hexavalente em diferentes substratos metálicos. Sais de terras raras têm sido utilizados com relativo sucesso em vários tipos de metais e ligas como forma de proteção à corrosão em ambientes marítimos (úmidos e de elevada taxa de corrosão). Os sais solúveis de terras raras, tais como cério, lantânio e ítrio são usados como inibidores eficazes de corrosão para ligas de alumínio (HINTON, 1992).

Para aços galvanizados, os sistemas preparados com sais de cério têm apresentado proteção contra a corrosão próxima à dos tratamentos convencionais com dicromato e com a formação de um óxido complexo de cério hidratado, com o cério em dois estados diferentes de oxidação: cério (III) e cério (IV) (XIA, 2000). As fontes precursoras para o cério na forma trivalente são, quase sempre, representadas por cloretos e nitratos. O uso destas fontes de cério é relatado para ligas de alumínio, aço e aço de baixa liga galvanizado (HILTON 1992, ALDYKIEWICZ, 1995).

Os resultados apresentados nesses trabalhos têm mostrado relativa eficácia na diminuição da cinética de corrosão em seus respectivos substratos, colocando os tratamentos com cério como promissores substituintes para os tratamentos de conversão de cromatos (ZANDI ZAND, 2012, 2013, ARAMAKI, 2002, KOBAYASHI, 2006). A maioria dos trabalhos que envolvem a formação de camada de conversão de cério usa o método de imersão, geralmente em temperaturas próximas à temperatura ambiente, como uma forma de minimizar os gastos energéticos (ARAMAKI, 2002). Existem também trabalhos que relatam a produção de camadas de conversão por eletrodeposição e tais resultados mostram-se muitas vezes superiores, quanto à proteção à corrosão, aos resultados obtidos por imersão, no entanto, com um custo mais elevado. Os trabalhos publicados, em sua maioria, mostram a eficiência dos banhos de conversão que utilizam nitrato de cério. Todavia, quanto aos mecanismos eletroquímicos de proteção a corrosão, não parece haver consenso (HINTON, 1989, ARAMAKI, 2001, MONTEMOR, 2001).

Desde os primeiros estudos do efeito de tratamento de imersão em solução contendo nitrato e/ou cloreto de cério (HINTON, 1992) até os dias atuais, os 
mecanismos de proteção convergem. Em ambos há consenso quanto à reação de oxidação de cério trivalente a cério tetravalente, mas com diferenças quanto à natureza do oxidante $\left(\mathrm{O}_{2}, \mathrm{H}_{2}\right.$ ou peróxido). No caso do oxidante oxigênio, o qual é consumido na vizinhança do catodo, o gradiente das duas espécies reativas, $\mathrm{O}_{2} \mathrm{e}$ $\mathrm{OH}^{-}$, têm direções opostas, de forma que a reação pode se dar somente a alguma distância do eletrodo. O oxidante pode também ser o peróxido, o qual é produzido na vizinhança do eletrodo (MONTEMOR, 2001).

Nos trabalhos com aço galvanizado (HINTON, 1992) ou com ligas de alumínio (KENDIG, 1993), tem sido mostrado que o efeito das reações catódicas, seja de redução do oxigênio ou evolução do hidrogênio, ao produzir aumento do pH local, causa a precipitação dos óxidos/hidróxidos de terras raras e, assim, ocorre precipitação de camada protetora sobre a superfície, dificultando a reação catódica, ou seja, atuando como inibidor catódico. Em meios aerados, a precipitação de cério em substratos de aço galvanizado é relatada como sendo mais efetiva na forma de $\mathrm{CeO}_{2}$, praticamente insolúvel em meio aquoso, equação 16 (ARAMAKI, 2001).

$$
2 \mathrm{Ce}^{3+}+6 \mathrm{H}_{2} \mathrm{O}_{2} \rightarrow 2 \mathrm{Ce}^{4+}+2\left(\mathrm{OH}^{-}\right)
$$

A reação de interesse é a oxidação do $\mathrm{Ce}^{3+}$ para $\mathrm{Ce}^{4+}$ na solução e, dessa forma, a etapa de oxidação, ao ocorrer na superfície do eletrodo, leva a uma deposição mais efetiva do filme de cério. No entanto, em diversos trabalhos foi relatado (ALDYKEWICZ, 1995; MONTEMOR, 2002; ARAMAKI, 2001) que, nos primeiros momentos, ocorre a formação de filme de cério trivalente.

Provavelmente, a presença de grande quantidade de cério trivalente na forma de hidróxido, no início da reação do substrato metálico com o banho de conversão, leve à precipitação gradativa de $\mathrm{Ce}(\mathrm{OH})_{3}$ com o aumento de $\mathrm{pH}$, devido à redução de oxigênio com formação de $\mathrm{OH}^{-}$. De certa maneira, o filme de hidróxido de cério trivalente formado cria uma barreira que dificulta a continuidade da reação entre o cério e o oxigênio: 


$$
2 \mathrm{Ce}^{3+}+\mathrm{OH}^{-} \rightarrow 2 \mathrm{Ce}(\mathrm{OH})_{3} \rightarrow \mathrm{Ce}_{2} \mathrm{O}_{3}+3 \mathrm{H}_{2} \mathrm{O}
$$

Esta hipótese de formação de filme de hidróxido de cério trivalente é reforçada em diversos trabalhos realizados com substrato de alumínio, em que a atuação do cério é indicada como inibidor da corrosão em ligas de alumínio contendo cobre. Nestas, a deposição do filme ocorre nos sítios catódicos ativos representados pelas inclusões ricas em cobre (ALDYKEWICZ, 1995).

Vários trabalhos têm investigado o efeito do tempo de imersão em soluções de nitrato de cério (MONTEMOR, 2001; LONG, 2003, LU, 2003, 2006; WANG, 1995, 2008; HAMLAOUI, 2009, 2013; ZANDI ZAND, 2012 e 2013). Nestes trabalhos, foi observado que tempos maiores de imersão resultam na formação de maior quantidade de $\mathrm{CeO}_{2}$. No entanto, o efeito de proteção contra a corrosão é foi inversamente proporcional ao tempo de imersão. Maiores tempos de imersão possibilitam a formação de filmes mistos, mais espessos, e com cério em dois estados de oxidação, 3 e 4 , os quais aparecem como $\mathrm{Ce}_{2} \mathrm{O}_{3}$ e $\mathrm{CeO}_{2}$, respectivamente.

Tem sido observado que as camadas formadas por tempos maiores de imersão do substrato metálico de zinco em solução contendo cério (nitratos e cloretos) são mais espessas, e apresentam $\mathrm{CeO}_{2}$ em maior quantidade que $\mathrm{Ce}_{2} \mathrm{O}_{3}$ (FERREIRA JR, 2013).

O mecanismo de inibição da corrosão do zinco por tratamentos em soluções com sais de cério foi investigado por ARAMAKI (ARAMAKI, 2002). Foi observada a formação de uma camada rica em hidróxido de cério a partir da adsorção de complexos de íons de cério na superfície hidroxilada do zinco, o que resulta na incorporação de cério na camada de produtos de corrosão do zinco, conforme indicado pelas reações 18 a 20.

$$
\begin{aligned}
& \mathrm{Zn}^{2+} \mathrm{OH}^{-}+\mathrm{Ce}^{3+}(\mathrm{OH})^{-} \rightarrow \mathrm{ZnOCe}^{3+} \mathrm{OH}^{-}+\mathrm{H}^{+} \\
& \mathrm{ZnOCe}^{3+} \mathrm{OH}^{-}+\mathrm{Ce}^{3+}(\mathrm{OH})^{-} \rightarrow \mathrm{ZnOCe}^{3+} \mathrm{OCe}^{3+} \mathrm{OH}^{-}+\mathrm{H}^{+} \\
& 2 \mathrm{ZnOCe}^{3+} \mathrm{OH}^{-}+\mathrm{Ce}^{3+}(\mathrm{OH})^{-} \rightarrow \mathrm{ZnOCe}^{3+} \mathrm{OCe}^{3+} \mathrm{OHOZn}+\mathrm{H}^{+}
\end{aligned}
$$


Os estudos sobre a proteção contra a corrosão de aços eletrozincados por tratamentos contendo cério apresentam às seguintes observações:

1) dentre os tipos de compostos testados, o nitrato de cério é mais efetivo contra a corrosão $\left(\mathrm{Ce}\left(\mathrm{NO}_{3}\right)_{3} \cdot 6 \mathrm{H}_{2} \mathrm{O}\right)(\mathrm{HINTON}, 1992)$;

2) o aumento no tempo de tratamento promove a formação de filmes mais espessos, menos protetores e com maior quantidade de cério depositado na forma de óxido tetravalente $\left(\mathrm{CeO}_{2}\right)$ (TRABELSI, 2005);

3) os mecanismos de formação dos filmes de cério não são totalmente compreendidos (ARAMAKI, 2002).

\subsubsection{Tratamentos em soluções contendo compostos de nióbio}

Outro tipo de elemento que vem sendo estudado para proteção contra a corrosão de material metálico é o nióbio (BANCZEK, 2013). Membro da família ou grupo do vanádio pode apresentar diferentes estados de oxidação: $\mathrm{Nb}^{1-}, \mathrm{Nb}^{0}$, $\mathrm{Nb}^{1+}, \mathrm{Nb}^{2+}, \mathrm{Nb}^{3+}, \mathrm{Nb}^{4+}$ e $\mathrm{Nb}^{5+}$. Entre esses estados, o que apresenta maior estabilidade quando na forma química de óxido é o $\mathrm{Nb}^{5+}$. A estabilidade do $\mathrm{Nb}_{2} \mathrm{O}_{5}$ à temperatura ambiente faz com que resista à ação de ácidos fortes, tais como, clorídrico, nítrico e sulfúrico (SAKHAROV, 1974, 1981).

O primeiro trabalho sobre deposição de nióbio para obtenção de camadas protetoras contra a corrosão foi o publicado por Cornish (CORNISH, 2008) e apontava para a possibilidade de deposição de nióbio por vapores. A descoberta da melhora na resistência à corrosão do aço quando o nióbio é adicionado como elemento de liga, ocorreu em 1932 e a sua principal aplicação tem sido desta forma, ou seja, como elemento de liga (BRANDÃO, 2009).

A obtenção de superligas, resistentes a altas temperaturas, usadas em jatos e aeronaves militares, passou a ser a aplicação mais disseminada do nióbio e dirigiu a estudos que levaram a aplicações (NOWAK, 1999, TANABE, 2003, RASPOLLI GALLETTI, 2010, REDSHAW, 2013). Estas vão desde ligas supercondutoras usadas em equipamentos médicos de última geração, até escapamentos automotivos (ANDERS, 2009). 
O emprego do elemento nióbio como revestimento na superfície dos metais foi de certa maneira limitada pela escassez de fontes precursoras e ou meios reacionais confiáveis que permitissem sua deposição na forma química e em quantidades desejáveis (VERMA, 2013). Assim, a evolução do uso de nióbio seguiu o desenvolvimento de técnicas químicas e/ou físicas de deposição de materiais (MOHAMMADI, 2013). Alguns estudos relatam a aplicação de nióbio de diferentes fontes (hidróxidos, oxalatos etc.) e por diferentes vias (sol gel, Pechini etc.), como forma de obtenção de óxidos usados como catalizadores (BENDAVID, 2003, BIERWAGEN, 2009, MOHAMMADI, 2013).

As novas aplicações testadas mudaram o foco das pesquisas, direcionando os estudos para diferentes estados de oxidação e formas ou vias de obtenção e deposição do mesmo (CATAURO, 2013). O uso de revestimentos de carbeto de nióbio, ou seja, com o nióbio no estado de oxidação quatro, passou a ser um dos mais estudados, por apresentar inúmeras aplicações tecnológicas, como alto ponto de fusão, alta dureza e tenacidade (BENDAVID, 2003). Os demais estados apresentam uma transição relativamente rápida e embora tenham sido feitos estudos com eles, suas aplicações, até o momento, são limitadas (MOHAMMADI, 2013).

A constatação da alta estabilidade do pentóxido de nióbio, $\mathrm{Nb}_{2} \mathrm{O}_{5}$, em presença de umidade, o coloca como o mais importante entre os óxidos de nióbio para resistência química. Esta alta estabilidade permite classificá-lo como inerte e não anfótero, embora reaja com ácido fluorídrico e, também, forme niobatos quando fundido com hidróxido de sódio (CAVALHEIRO, 1999, OLSSON, 2004).

O uso de óxidos de nióbio e, principalmente, do pentóxido de nióbio $\left(\mathrm{Nb}_{2} \mathrm{O}_{5}\right)$, apresenta-se como uma promessa de obtenção de novas camadas protetoras para diferentes tipos de substratos. Estas apresentam melhora na proteção à corrosão do substrato formando camada barreira entre o meio corrosivo e o substrato metálico. Todavia, até o momento, os trabalhos publicados têm indicado dificuldade na obtenção de camadas com espessuras controláveis, uniformes e que sejam reprodutíveis (CATAURO, 2013, OLSSON, 2004).

Mais recentemente, um composto de nióbio, especificamente o oxalato de nióbio amoniacal (ANO) bi hidratado, foi investigado para aplicação em banhos de 
fosfatização de aço ou de aço eletrozincado, como potencial substituto do níquel, visando à diminuição de geração de resíduos prejudiciais ao ambiente e apresentam resultados promissores na capacidade de proteção contra a corrosão de substrato metálico (BANCZEK, 2008; YAMAGUTI, 2012).

A aplicação do ANO em processos de proteção contra a corrosão de substratos de zinco não é relatada na literatura. Esta escassez de pesquisas para esta aplicação motivou o interesse em testá-lo como um potencial aditivo para tratamento da superfície do aço eletrozincado, com o objetivo de avaliar o seu efeito na resistência à corrosão do substrato de zinco.

Resultados obtidos no Laboratório de Eletroquímica e Revestimentos Protetores do CCTM/IPEN mostraram que o tratamento de imersão de aços eletrozincados em soluções contendo ANO e com concentração de nióbio correspondente a 200 ppm e pH 4 resultaram em maior quantidade de nióbio na superfície em comparação com soluções de pH neutro $(6,5)$ ou muito ácidos, pH 2 (FERREIRA JR, 2011).

O aumento na concentração dos banhos de conversão não resultou em maiores quantidades de nióbio superficial, pois soluções com concentrações maiores que 200 ppm em pH 4 necessitam de aumento da concentração de solução tampão contendo outras espécies químicas $\left(\mathrm{Na}^{+}, \mathrm{K}^{+}, \mathrm{PO}_{4}{ }^{3+}\right)$, mais reativas que nióbio, e que reagem e precipitam preferencialmente na superfície, ocupando os sítios que poderiam ser ocupados pelo nióbio (FERREIRA JR, 2011).

Os revestimentos obtidos continham óxidos e hidróxidos de zinco e óxidos de $\mathrm{Nb} \vee$ e $\mathrm{Nb}$ IV, e estes contribuíram para o aumento das propriedades protetoras dos filmes passivos formados na superfície em meios contendo cloreto. Todavia, foi observado que os filmes formados pela imersão de aço eletrozincado, sem uso de corrente externa, nas soluções de ANO, não resultaram em proteção duradoura, o que foi identificado pelo elevado aumento de corrente durante polarização anódica e diminuição da impedância com o tempo de imersão em meio corrosivo (FERREIRA Jr, 2011).

Resultados obtidos inicialmente mostraram que a camada formada e caracterizada como sendo de óxido de nióbio pentavalente possui baixa 
capacidade de proteção, que foi atribuída à alta porosidade da mesma (FERREIRA Jr, 2012). Estes resultados apontaram para a necessidade de se associar o tratamento com oxalato de nióbio com outros tratamentos que resultassem em proteção mais duradoura. Estes fatos levaram a proposição de novas soluções e novas rotas de síntese, as quais foram testadas no presente trabalho, detalhado em Materiais e Métodos. 


\section{MATERIAIS E MÉTODOS}

\subsection{Eletrodeposição de zinco}

Chapas de aço SAE/AISI 1010 de dimensão $100 \mathrm{~mm} \times 65 \mathrm{~mm} \times 1 \mathrm{~mm}$ e cuja composição química é mostrada na Tabela 1 foram revestidas com zinco, por processo de eletrodeposição, utilizando-se banho alcalino de zinco isento de íons cianeto, conhecido comercialmente por NCZ (Non-Cyanide Zinc). Estes banhos eletrolíticos são econômicos e de baixo impacto ambiental sendo usados comercialmente. O uso deste substrato é de interesse industrial uma vez que é aplicado no segmento automotivo na confecção de carrocerias e os prétratamentos como ativação em ácido nítrico seguem as mesmas disposições usadas industrialmente.

Tabela 1: Composição nominal (\% em massa) do aço SAE/AISI 1010 usado como substrato para eletrodeposição de zinco.

\begin{tabular}{lcccc}
\hline Aço SAE/AISI & \multicolumn{3}{c}{ Composição química } & (\% massa) \\
\hline & $\mathbf{C}$ & Mn & P max & S max \\
\hline $\mathbf{1 0 1 0}$ & $0,08-0,13$ & $0,3-0,6$ & 0,030 & 0,050
\end{tabular}

O processo de eletrodeposição adotado foi o de corrente contínua, com retificador de corrente máxima correspondente a 5A (Instrutherm Dc Power Supply FA-3005). Para garantir reprodutibilidade e obtenção regular de espessura de zinco na faixa de $10 \mu \mathrm{m}$, foi montada uma linha de eletrodeposição em escala reduzida e utilização de reagentes de padrão analítico. As etapas do processo de eletrodeposição foram realizadas no Laboratório de Eletroquímica e Revestimentos Protetores do CCTM/IPEN e são mostradas esquematicamente na Figura 4. 


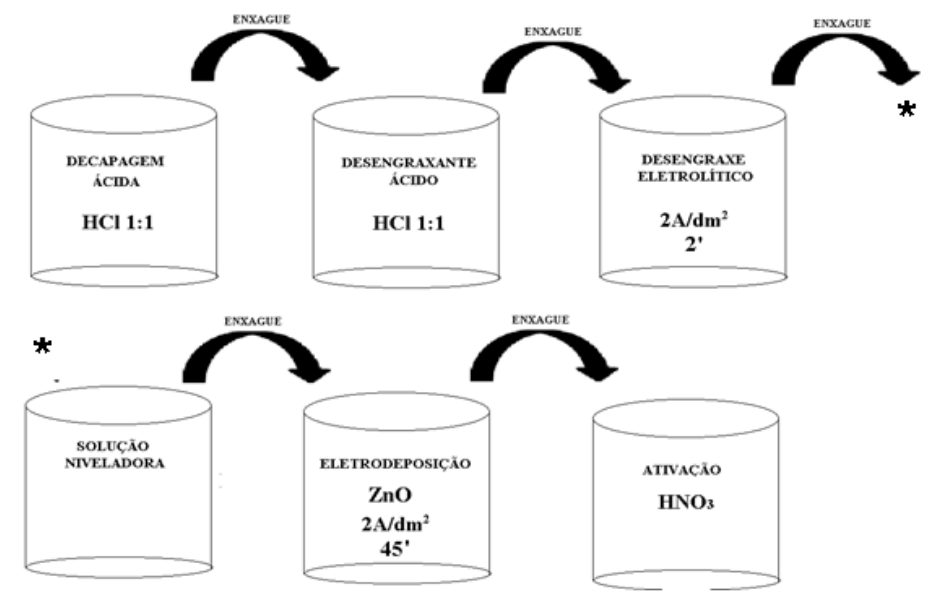

Figura 4: Representação esquemática do processo de eletrodeposição de zinco utilizado.

Os parâmetros adotados nas várias etapas do processo de eletrodeposição são indicados a seguir: decapagem ácida $(\mathrm{HCl} 1: 1-50 \% \mathrm{v} / \mathrm{v})$; enxágue; desengraxe ácido por 30 segundos $10 \mathrm{ml} / \mathrm{L}$ de inibidor de ferro para proteção contra a fragilização por hidrogênio; enxágue; desengraxe eletrolítico $\left(2 \mathrm{~A} / \mathrm{dm}^{2}\right.$ por 2 minutos); enxágue, imersão em solução ativadora comercial por 20 segundos contendo $5 \%$ de bifluoreto de amônio; enxágue; eletrodeposição em solução contendo óxido de zinco (banho de zinco), enxágue; carbonato e hidróxido de potássio com aditivos condicionadores, niveladores e abrilhantadores $\left(2 \mathrm{~A} / \mathrm{dm}^{2}\right.$ por 45 minutos); enxágue; ativação em solução de ácido nítrico com $\mathrm{pH}=1$ enxágue e, finalmente, passivação (objeto de estudo deste trabalho).

Entre todas as etapas enumeradas acima, houve enxágue em água deionizada. Os aditivos niveladores e abrilhantadores usados nos banhos de eletrodeposição de zinco controlam propriedades do depósito: brilho, aderência, homogeneidade e refino de grãos. Outra função dos aditivos é a solubilização do zinco no banho, permitindo alto rendimento da espécie depositada.

\subsection{Determinação da espessura da camada de zinco obtida}

As espessuras dos eletrodepósitos de zinco foram estimadas por observação da secção transversal de amostras da chapa de aço eletrogalvanizada utilizando técnicas de microscopia eletrônica de varredura após 
preparação metalográfica, seguida por crio fratura. A reprodutibilidade dos revestimentos de zinco eletrodepositadas foi avaliada com a camada de zinco mensurada por dois diferentes processos de preparação de amostra, após crio fratura e após embutimento e polimento químico. Neste tipo de avaliação foi utilizado um Microscópio Eletrônico de Varredura (LEO 1450VP SEM).

\subsection{Tratamentos de passivação}

Os tratamentos de passivação utilizados neste estudo para proteção contra a corrosão do aço eletrozincado, com materiais orgânicos, cério e nióbio são propostas originais deste estudo, não havendo sido estudados anteriormente por outros pesquisadores. Os materiais utilizados nestes tratamentos de passivação são atóxicos ou de baixa toxicidade, de forma que os tratamentos propostos podem ser considerados de tecnologia limpa. Nesta linha, compostos de cério e de nióbio foram os investigados como possíveis substitutos para processos que geram resíduos tóxicos. Estes foram utilizados separadamente e combinados, em sequência, sendo realizados testes preliminares para avaliar sua eficiência de proteção (corrosão acelerada). A partir dos resultados preliminares, foram selecionadas duas soluções para passivação, cujas composições são apresentadas a seguir:

(1) Solução de passivação com cério: $0,050 \mathrm{~mol} \cdot \mathrm{L}^{-1}$ de nitrato de cério hexahidratado; 0,020 mol.L-1 de nitrato de sódio; $0,020 \mathrm{~mol}^{-\mathrm{L}^{-1}}$ de sulfato de sódio e 10 \% v/v de 2-Butino-1,4-diol propoxilato.

(2) Solução de passivação com oxalato de nióbio amoniacal: 500 ppm de oxalato de nióbio amoniacal (ANO); 0,020 mol.L-1 de nitrato de sódio; 0,020 mol. ${ }^{\mathrm{L}-1}$ de sulfato de sódio e $10 \% \mathrm{v} / \mathrm{v} /$ de 2-Butino-1,4-diol propoxilato.

Entre as etapas 1 e 2 foi testado o tratamento de imersão em solução de peróxido de hidrogênio $1 \% \mathrm{v} / \mathrm{v}$ por 1,10 e 20 minutos, sequencialmente ao tempo de tratamento da etapa 1 que apresentou melhores resultados quanto à proteção à corrosão mensurados por ensaio de corrosão acelerado em câmara de névoa 
salina e espectroscopia de impedância eletroquímica.

Cada nova etapa de tratamento foi realizada com três diferentes tempos de imersão (1, 10 e 20 minutos) sempre sequencialmente ao tempo da etapa anterior que apresentou melhores resultados quanto à proteção a corrosão. $O$ tratamento de passivação do revestimento de zinco foi realizado por imersão das chapas de aço eletrogalvanizadas, segundo as seguintes condições e etapas:

a) imersão em solução contendo cério por três períodos diferentes, 1, 10 e 20 minutos, denominados, respectivamente, T1, T10 e T20.

b) Realização de ensaios em câmara de névoa salina, segundo norma ASTM B117, e ensaios eletroquímicos de espectroscopia de impedância eletroquímica (EIE), resultando na seleção do tratamento T10 como o que apresentou maior resistência à corrosão entre os testados.

c) Imersão em solução contendo nitrato de cério (III) hexahidratado por 10 minutos (T10), seguida por imersão em solução $1 \% \mathrm{v} / \mathrm{v}$ de peróxido de hidrogênio durante diferentes tempos, a saber, 1, 10 e 20 minutos. Estes tratamentos foram denominados como T10_1; T10_10 e T10_20.

d) Realização de ensaios de névoa salina, segundo norma ASTM B117 (BABOIAN, 2005), e ensaios eletroquímicos de espectroscopia de impedância eletroquímica (EIE), resultando na seleção do tratamento T10_10 como o que apresentou maior resistência à corrosão entre os tempos testados (T10_1, T10_10 e T10_20).

e) Imersão em solução contendo oxalato de nióbio amoniacal (ANO) da amostra com o tratamento T10_10 por três períodos de tempo diferentes, 1, 10 e 20 minutos, denominados, respectivamente, T10_10_1, T10_10_10 e T10_10_20.

f) Realização de ensaios em câmara de névoa salina, segundo norma ASTM B117, e ensaios eletroquímicos de espectroscopia de impedância eletroquímica (EIE), resultando na seleção do tratamento T10_10_10 como o que apresentou maior resistência à corrosão entre os tratamentos testados (T10_10_1, T10_10_10 e T10_10_20). 
A temperatura das soluções de tratamento de passivação foi de $25^{\circ} \mathrm{C}$, e a temperatura de secagem, $80^{\circ} \mathrm{C}$. Para manutenção e controle da temperatura a $25^{\circ} \mathrm{C}$ foi utilizado um banho maria microprocessado com agitação mecânica (Prolab modelo Jf32). Já os valores de $\mathrm{pH}$ e as condutividade das soluções adotadas foram obtidos com pHmetro e condutivímetro (SPLABOR HI 1110B pH21). A tabela 2 apresenta os reagentes usados, suas respectivas concentrações, composições das soluções de passivação e nomenclatura adotada neste trabalho.

Tabela 2: Reagentes, parâmetros usados na obtenção do banho de conversão, constituição dos tratamentos de conversão e nomenclatura.

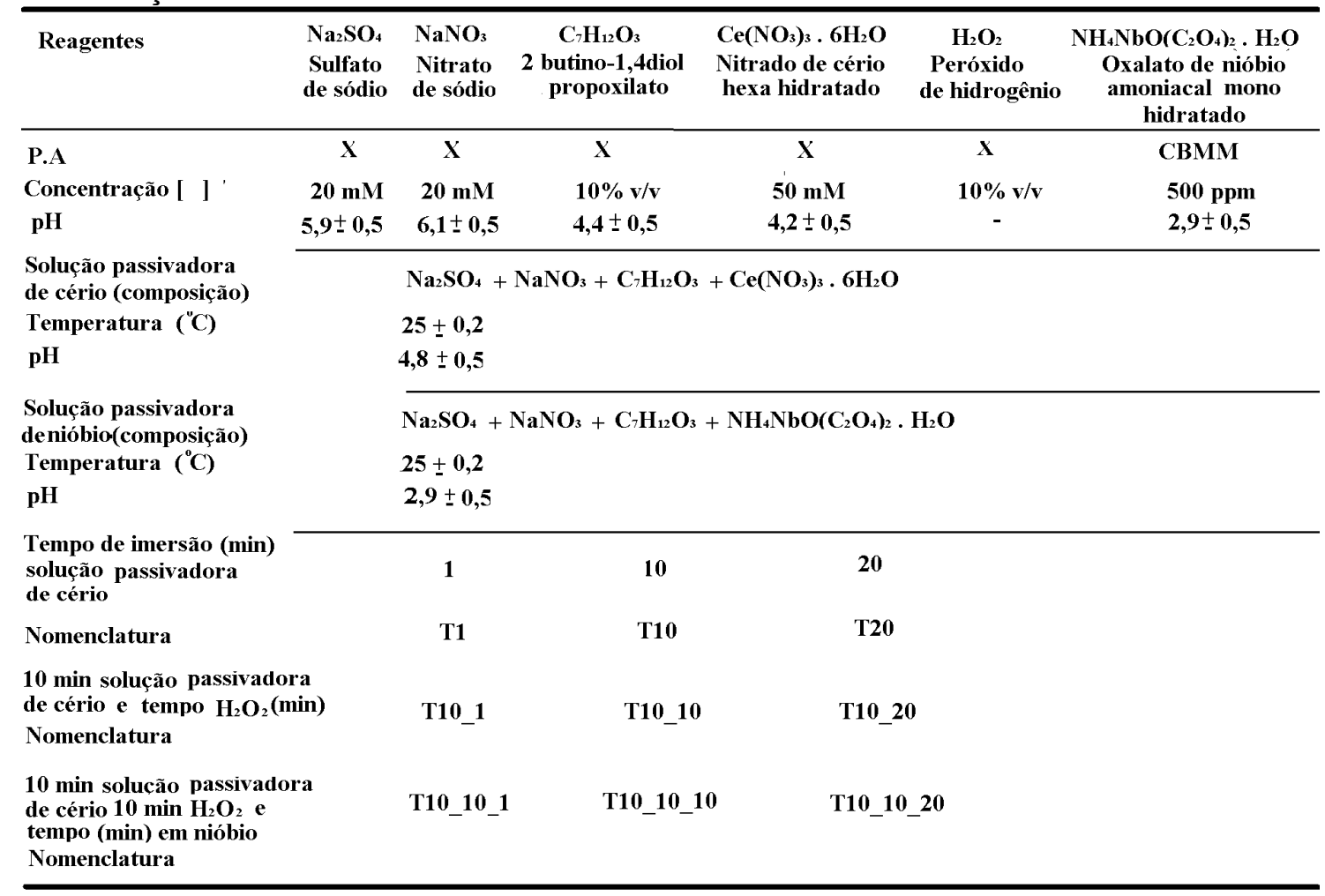

A preparação das soluções propostas no presente trabalho partiu de informações referenciadas na literatura sobre tratamentos que promovem melhoras nas propriedades de proteção a corrosão, e esses compostos foram usados na elaboração das mesmas. Das muitas camadas orgânicas propostas como proteção ao substrato de aço eletrozincado, não há referência na literatura sobre o uso de 2 butino 1,4 diol propoxilato como precursor destas camadas 
orgânicas (STRATMANN, 1994, MAEGE, 1998, WESSLING,1999, GRUNDMEIER, 2000 e HAMLAOUI, 2013).

O elemento cério foi escolhido por apresentar os melhores resultados quanto à proteção à corrosão, entre os demais elementos da série dos lantanídeos (HINTON, 1992, ARAMAKI, 2001, MONTEMOR, 2002). Este elemento foi utilizado na forma de nitrato hexahidratado, mais eficiente que cloretos (ARAMAKI, 2001) do mesmo elemento. O nitrato de sódio e sulfato de sódio, empregados como sais que não sofrem hidrólise e que, portanto não alteram significativamente $\mathrm{o} \mathrm{pH}$ da solução de tratamento foram usados separadamente ou juntos, em diversas pesquisas sobre eficiência protetiva de cério em substratos metálicos (KOBAYASHI, 2006, VEYS-RENAUX, 2013, HOSSEINI, 2007)

O emprego do Oxalato de Nióbio Amoniacal (ANO) como precursor de nióbio levou em consideração informações sobre sua solubilidade e acidez da solução, as quais foram utilizadas no preparo das soluções adotadas (SEN, 2004). A hipótese proposta para o uso deste composto é que resulte na incorporação do óxido estável de nióbio, $\mathrm{Nb}_{2} \mathrm{O}_{5}$, em quantidade suficiente para promover a estabilidade dos filmes formados em meios mais corrosivos.

A originalidade desta tese consiste na elaboração e aplicação de soluções contendo 2 butino-1,4 diol propoxilato com cério e 2 butino 1,4 diol propoxilato com nióbio como tratamento de proteção ao aço eletrozincado. A escolha do composto orgânico 2 butino-1,4 diol propoxilato se deu pelo fato deste composto já ser utilizado na etapa de eletrodeposição, no banho de zinco, como aditivo e principalmente por ser um composto de função mista éter/álcool, o que, possibilita seu uso como precursor de ácidos carboxílicos quando em presença de meios oxidantes. Estes também são relatados como grupos funcionais precursores poliméricos (PÁSAN, 2011).

No desenvolvimento das soluções de tratamento foi observada a necessidade do uso de aditivos oxidantes não hidrolisáveis. Os reagentes oxidantes usados foram o sulfato de sódio e nitrato de sódio. As soluções utilizadas foram compostas de nitrato de cério hexahidratado, oxalato de nióbio amoniacal (ANO), 2 butino 1,4 diol propoxilato, nitrato de sódio e sulfato de sódio. 


\subsection{Caracterização das camadas obtidas (diferentes tratamentos testados)}

\subsubsection{Caracterização química}

A composição química da camada formada foi avaliada pelas técnicas de Espectroscopia no Infravermelho por Transformada de Fourier (IR-FTIR) e Espectroscopia Fotoeletrônica de raios X (XPS), com resultados apresentados nesta respectiva ordem.

\subsubsection{A Espectroscopia no Infravermelho por Transformada de Fourier (FTIR)}

A espectroscopia no infravermelho por transformada de Fourier (FTIR) é uma importante técnica de caracterização de materiais, sendo muito utilizada na identificação da natureza química de vários tipos de materiais e, principalmente, de revestimentos orgânicos.

Neste trabalho, foi utilizado espectrômetro Perkin Elmer, modelo CHN 2400 e a aquisição de dados para a caracterização da camada obtida ocorreu na faixa de comprimento de ondas de $500 \mathrm{~cm}^{-1}$ a $4000 \mathrm{~cm}^{-1}$. Para a caracterização das soluções adotadas, foi utilizado espectrômetro Varian modelo 600-IR, na mesma faixa de comprimento de onda acima. Os resultados serão expressos como absorbância em função do comprimento de onda. Para a interpretação dos espectros obtidos, foi adotada a região entre $1800 \mathrm{~cm}^{-1}$ e $1600 \mathrm{~cm}^{-1}$ como região de impressão digital e que permite classificar e/ou identificar compostos como inorgânicos ou orgânicos.

Partindo desta região, modos vibracionais ou bandas de absorção de interesse foram referenciados da seguinte maneira: $(-\mathrm{C}=\mathrm{O})$ carbonila como bandas entre $3500 \mathrm{~cm}^{-1}$ a $3200 \mathrm{~cm}^{-1} ;(-\mathrm{OH})$ hidroxilas como banda larga entre $3400 \mathrm{~cm}^{-1}$ a $2700 \mathrm{~cm}^{-1}$ presentes em ácidos orgânicos, ácido carboxílico; (C-O) como bandas entre $1300 \mathrm{~cm}^{-1}-1000 \mathrm{~cm}^{-1}$ referentes a modo vibracional de ligação carbono oxigênio de ácido carboxílico; $(\mathrm{C}-\mathrm{H})$ como bandas entre $3000 \mathrm{~cm}^{-1}-2800$ $\mathrm{cm}^{-1}$ de compostos alifáticos saturados, $(\mathrm{C}-\mathrm{H})$ como bandas entre $3100 \mathrm{~cm}^{-1}-3300$ $\mathrm{cm}^{-1}$, correspondentes ao modo vibracional de compostos alifáticos insaturados (SOCRATES, 1994). 
A banda de absorção centrada entre $1655 \mathrm{~cm}^{-1}-1630 \mathrm{~cm}^{-1}$ foi adotada como correspondente ao estiramento do grupo orgânico alceno $(C=C)$, e bandas de absorção localizadas em $815 \mathrm{~cm}^{-1}\left(-\mathrm{CH}_{3}\right), 992 \mathrm{~cm}^{-1}\left(\mathrm{CH}_{2}-\right), 1120 \mathrm{~cm}^{-1}\left(-\mathrm{CH}_{3}\right)$, $1980 \mathrm{~cm}^{-1}$ e $2120 \mathrm{~cm}^{-1}$, como referentes a $(-\mathrm{C}=\mathrm{O})$ de grupo carboxil. Estas foram adotadas como referências para as demais estruturas orgânicas possíveis (TAHERI, 2011).

Dentre as espécies inorgânicas de interesse foram adotados os seguintes: para o elemento cério, nas formas químicas óxido e nitrato, os modos vibracionais correspondentes a, respectivamente, $600 \mathrm{~cm}^{-1}, 1120 \mathrm{~cm}^{-1}$, e para o elemento zinco, bandas de absorbância entre $1120 \mathrm{~cm}^{-1}$ e $1.478 \mathrm{~cm}^{-1}$, correspondentes ao modo vibracional do carbonato de zinco $\left(\mathrm{ZnCO}_{3}\right)$ possivelmente devido a adsorção de dióxido de carbono dissolvido no meio (SOCRATES, 1994).

As referências citadas foram utilizadas para a interpretação dos espectros dos filmes de conversão e das soluções precursoras. Estas, portanto, se aplicam à caracterização dos filmes e dos meios líquidos obtidos com uso de pastilhas de brometo de potássio. Para os meios líquidos, a representação dos espectros foi feita com a subtração de sinal de fundo originado pelo brometo de potássio.

\subsubsection{Espectroscopia fotoeletrônica de raios $X(X P S)$}

A superfície passivada foi analisada quimicamente por XPS usando um espectrômetro Scientific Thermofisher (East Grinstead, UK) Theta Probe. Os espectros XPS adquiridos utilizaram fonte de raios $\mathrm{X}$ com monocromador $\mathrm{Al} \mathrm{Ka}$ ( $h v=1486,6 \mathrm{eV}$ ). $A$ análise de raios $X$ com raio local de $400 \mu \mathrm{m}$ e espectros de alta resolução foram adquiridos com passos de $50 \mathrm{eV}$ para as espécies de interesse, como cério e nióbio. Os demais espectros foram adquiridos com passos de $30 \mathrm{eV}$, caso de carbono, zinco e oxigênio.

A metodologia adotada no presente trabalho, para as análises de Espectroscopia fotoeletrônica de raios X (XPS) consiste na obtenção espectros gerais (rápidos) para três pontos superficiais, visualmente distintos. De posse dos três espectros, o primeiro passo foi constatar se os mesmos elementos estavam presentes e, depois, se as quantidades destes elementos não apresentavam 
variação maior que $10 \%$ entre elas. Com erro menor que $10 \%$, todas as novas analises, de maior resolução e perfil de profundidade, foram realizadas no ponto 1. Caso as análises mostrassem diferentes, elementos e/ou quantidades com erro maior que $10 \%$, um dos pontos (posição) era alterado até que o erro assumisse valor aceitável.

O espectro XPS geral permite observar a presença dos elementos superficiais e, após escolhido o ponto, segundo metodologia adotada, novos espectros são obtidos com melhor resolução (maior número de varreduras) para todas as espécies identificadas. Para todas as análises XPS, após a obtenção do espectro geral, no ponto de reprodutibilidade adotado foram realizadas 30 varreduras para carbono, oxigênio, zinco e, 50 varreduras para as espécies cério e nióbio. O número de varreduras adotado é um padrão de uso do equipamento e refere-se à intensidade de sinal. Quanto mais baixos os sinais, maiores os números de varreduras (scans). Na Figura 5 são mostrados três pontos visuais diferentes (macroscópicos) de análise adotada para XPS, respectivamente para as amostras com tratamentos: A) T1; B) T10 e C) T20.

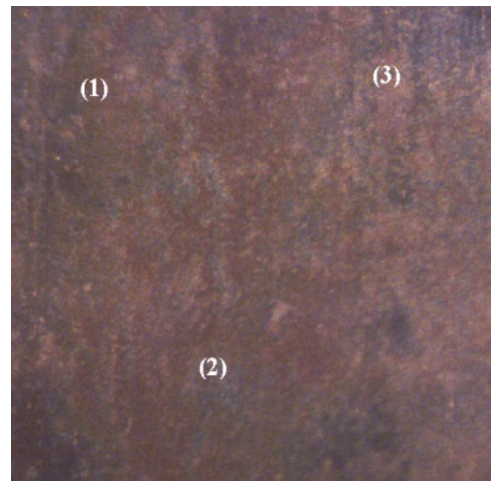

(A)

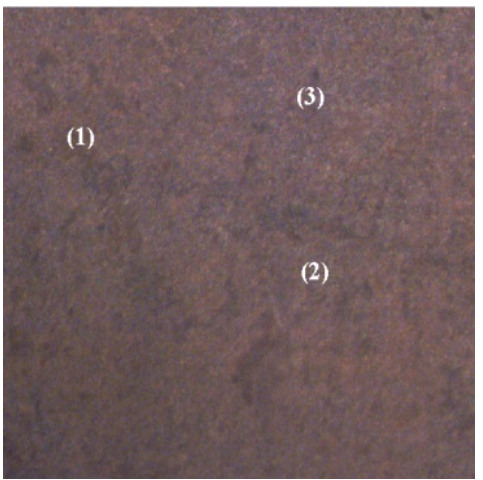

(B)

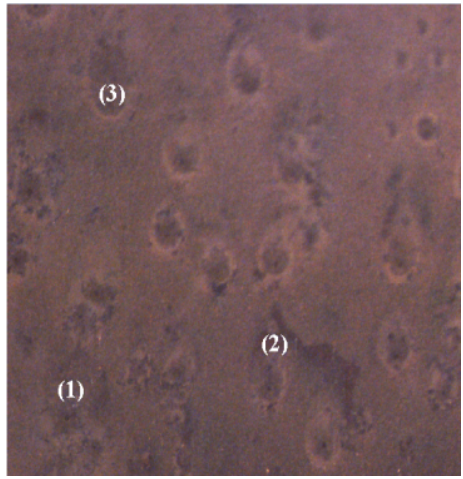

(C)

Figura 5: Diferentes pontos selecionados para análise por XPS, respectivamente para as amostras com tratamentos: (A) T1; (B) T10 e (C) T20.

Também foram obtidos perfis de profundidade em tempos progressivos de incidência de íons argônio (sputtering), sendo estes sucedidos por análises de XPS. Cada ciclo etch expõe uma nova superfície, e os espectros adquiridos são 
uma nova via de análise da composição química da superfície, sendo a profundidade diretamente proporcional ao tempo de sputtering. O tempo máximo de "sputtering" adotado no presente trabalho foi de 480 segundos. Este tempo é inferior ao tempo necessário para que haja a mudança de estados químicos por excitação dos íons de argônio incidentes.

Os resultados de XPS serão apresentados na forma de espectros Survey, com o pico de carbono C1s, usado como fator de ajuste em 285 eV, oxigênio O1s em 532 eV, zinco 2 $p_{3 / 2}$ em 1022 eV, cério $3 d_{5 / 2}$ e nióbio $N_{b 3} d_{5 / 2}$ em 207 eV. Os gráficos dos picos identificados e curvas de ajustes "fitting" para as espécies químicas identificadas foram suprimidos deste texto. Os resultados serão apresentados na forma de tabelas para tornar o texto mais coeso e elucidativo.

\subsubsection{Caracterização Superficial (Morfológica e estrutura de fase)}

A avaliação da morfologia das camadas obtidas pelos vários tratamentos testados foi realizada em Microscópio Eletrônico de Varredura com EDS (LEO 1450VP SEM) utilizando detector de elétrons retro espalhados e microscopia eletrônica de varredura com Field Emission Gun (JEOL JSM-6330F FEG-SEM). As superfícies das amostras tratadas foram analisadas for microscópio óptico Leica M205 C e as imagens 3D, foram obtidas pelo software Leica 3D. Todas as imagens tridimensionais obtidas são apresentadas com aumento de 50 vezes.

As medidas de Difração de Raios $X$ analisadas neste trabalho foram realizadas em um difratômetro da Rigaku modelo Ultima -IV utilizando radiação CuKa $(\lambda=1,54178)$, no Laboratório de Cristalografia Aplicada às Ciências dos Materiais (CristalMat) do IPEN. O intervalo de análise foi de $5-50^{\circ} \mathrm{com}$ passos de 0,05 , em intervalos de 2 segundos por passo.

\subsubsection{Ensaios acelerados em câmara de névoa salina}

Ensaios de corrosão acelerada foram realizados em câmara de névoa salina, de acordo com a norma ASTM B117 (ASTM B117). Para estes ensaios, foi utilizada câmara, EQUILAM modelo SSG1. A evolução da corrosão superficial dos 
corpos de prova ao longo do ensaio foi monitorada e registrada por fotografias em função do tempo de exposição. Esta técnica foi utilizada como referência para seleção de tratamentos que possibilitem diminuição do processo de corrosão. Vale ressaltar que, durante todo o estudo, o ensaio de corrosão acelerada, segundo norma ASTM B117, foi usado para selecionar tratamentos quanto à habilidade protetiva dos revestimentos formados. Um tratamento comercial de conversão para formação de camada de cromato foi também adotado como referência Os tratamentos de passivação com resistência à corrosão, inferiores aos da referência, cromato, foram desconsiderados na continuidade da pesquisa.

Nos ensaios de névoa salina foram testadas amostras em triplicata para cada condição superficial ensaiada para investigar a reprodutibilidade dos resultados.

\subsubsection{Caracterização eletroquímica}

Os banhos de conversão de cromatos também foram utilizados para a obtenção de peças de aço eletrozincado passivado em eletrólito à base de íons de cromo hexavalente. Estas peças com filme de cromatos (Cr-VI) foram usadas nos ensaios eletroquímicos como referência, forma comparativa de valores de impedância e proteção à corrosão. Os ensaios eletroquímicos foram realizados com arranjo convencional de célula de três eletrodos, representada na Fig. 6.

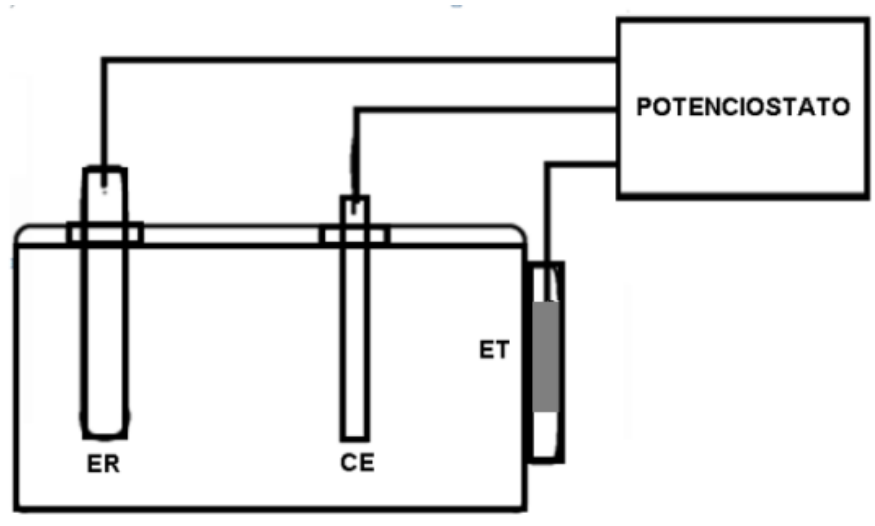

Figura 6: Representação esquemática do arranjo experimental adotado para análise eletroquímica. 
Como arranjo experimental foi utilizada uma célula de três eletrodos, constituída por eletrodo de referência de $\mathrm{Ag} / \mathrm{AgCl}$ saturado, contra eletrodo de platina, com área aproximada de $1 \mathrm{~cm}^{2}$, e eletrodo de trabalho representado pela peça ou amostra analisada, com área exposta de $1 \mathrm{~cm}^{2}$. A evolução da corrosão em função do tempo de imersão em solução de $\mathrm{NaCl} 0,1$ mol.L $\mathrm{L}^{-1}$ foi monitorada por espectroscopia de impedância eletroquímica (EIE). Todas as condições de superfície investigadas foram ensaiadas em triplicata a fim de avaliar a reprodutibilidade dos resultados.

Os experimentos de espectroscopia impedância eletroquímica foram conduzidos na faixa de frequência de $100 \mathrm{kHz}$ a $10 \mathrm{mHz}$, com amplitude de sinal de perturbação de $10 \mathrm{mV}$, e taxa de aquisição de dados de 10 pontos por década. Precedendo os ensaios de EIE, o potencial de circuito aberto (PCA) foi monitorado por tempos suficientes para que houvesse estabilização destes, para permitir validação dos resultados de espectroscopia de impedância eletroquímica. Os resultados de EIE foram obtidos no PCA após estabilização do potencial, utilizando potenciostato marca BioLogic, modelo SP200 controlado, por software EcLab. Os resultados serão apresentados na forma dos diagramas Nyquist e Bode ângulo de Fase (graus) vs frequência. 


\section{RESULTADOS E DISCUSSÃO}

Os resultados serão apresentados sequencialmente em três grupos, a saber:

(1) Morfologia e composição química dos revestimentos de zinco por Microscopia Eletrônica de Varredura de alta resolução (MEV/FEG) e Espectroscopia de Energia Dispersiva (EDS).

(2) Composição química dos reagentes e soluções passivadoras por Espectroscopia no Infravermelho por Transformada de Fourier (FTIR).

(3) Morfologia e composição química das camadas formadas pelos tratamentos de passivação propostos por Microscopia Eletrônica de Varredura de alta resolução (MEV/FEG), Difração de raios $X$ (DRX), Espectroscopia no Infravermelho por Transformada de Fourier (FTIR), Espectroscopia Fotoeletrônica de raios X (XPS), Espectroscopia de Impedância Eletroquímica (EIE) e Ensaios de Corrosão Acelerada em câmara de névoa salina.

\subsection{Morfologia dos depósitos de zinco}

A espessura, composição e morfologia da camada de zinco sobre a qual são depositados os filmes investigados, no presente trabalho, podem comprometer os resultados relacionados à resistência à corrosão, caso estas camadas de zinco apresentem variação significativa quanto à constituição química, espessura e uniformidade.

Para que não haja variação na constituição química e dimensão da camada eletrodepositada, os parâmetros de eletrodeposição foram fixados e os revestimentos de zinco mensurados. A espessura das camadas foi determinada por Microscopia Eletrônica de Varredura de alta resolução (MEV/FEG) e Espectroscopia de Fluorescência de Raios X (FRX). 
As chapas de aço SAE/AISI 1010 após serem eletrozincadas foram ativadas em ácido nítrico, enxaguadas e secas e, em seguida, embutidas em resina acrílica para análise em microscópio eletrônico de alta resolução (FEG). As secções transversais das amostras foram preparadas para observação por criofratura ou polimento químico. As Figuras 7 e 8 mostram as secções transversais de amostras eletrozincadas, após criofratura e polimento químico, respectivamente.

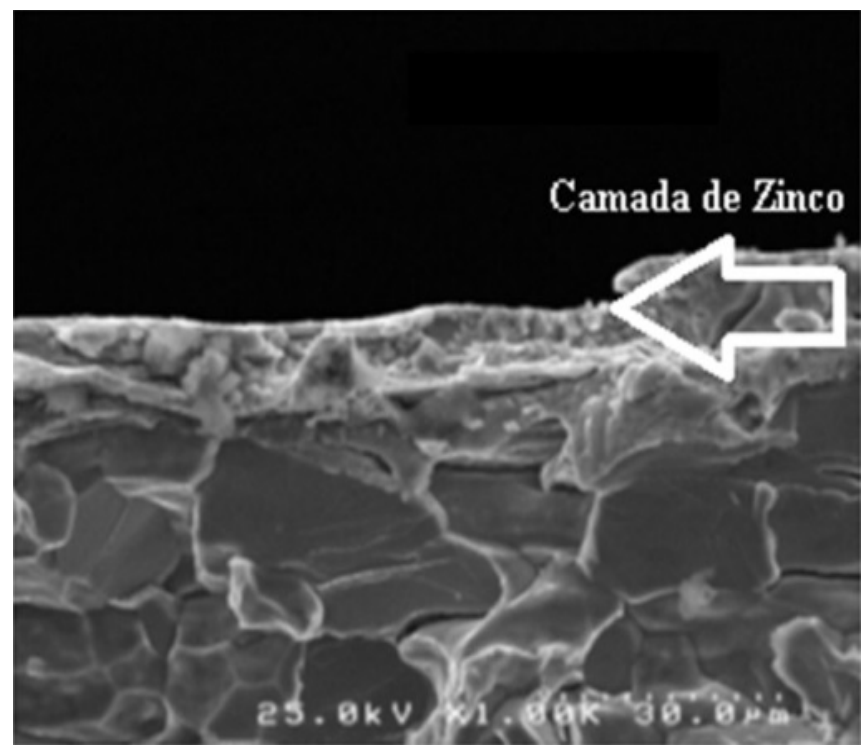

Figura 7: Micrografia obtida por FEG (1000x) para amostra de aço SAE/AISI 1010 eletrozincado embutida em resina acrílica após ativação e crio fratura.

A micrografia da secção transversal permite observar que a camada de zinco eletrodepositada é contínua, uniforme e possui espessura da ordem de 10 $\mu \mathrm{m}$. Na busca por respostas sobre a reprodutibilidade do processo de eletrodeposição, novas amostras foram preparadas por crio fratura (em nitrogênio líquido) e por polimento. As secções transversais foram analisadas por microscopia eletrônica de alta resolução (FEG) e espectroscopia de energia dispersiva (EDS). A Figura 8, item (A), apresenta micrografia obtida por FEG para o aço eletrozincado, crio fraturado, e (B) espectro EDS obtido. 


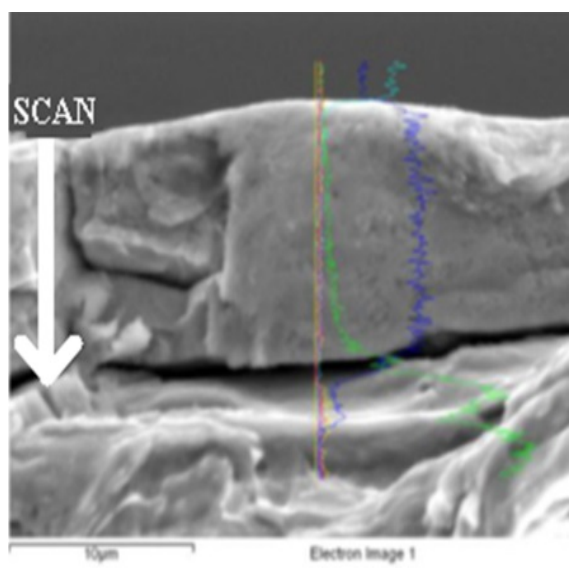

(A)

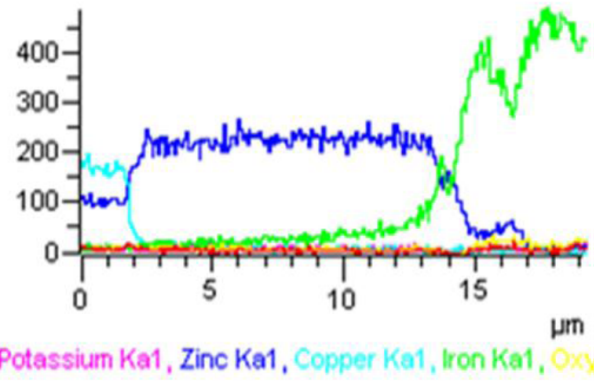

(B)

Figura 8: A) Micrografia obtida por FEG de secção transversal de aço eletrozincado criofraturado, em atmosfera de nitrogênio líquido $\left(\mathrm{N}_{2}\right)$; $\left.B\right)$ Espectro de EDS em linha.

A micrografia e espectro em linha permitem observar que a camada de zinco apresenta aproximadamente $10 \mu \mathrm{m}$ de espessura e é constituída basicamente por zinco. A Figura 9, item (A), mostra a micrografia obtida por FEG para o aço eletrozincado polido e (B) espectro EDS obtido.

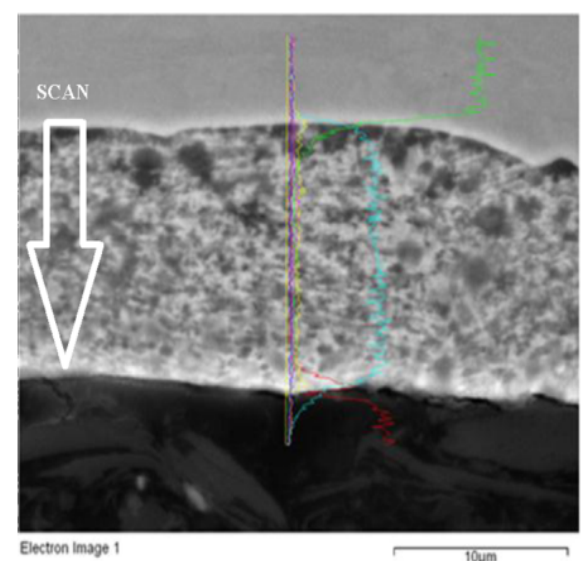

(A)

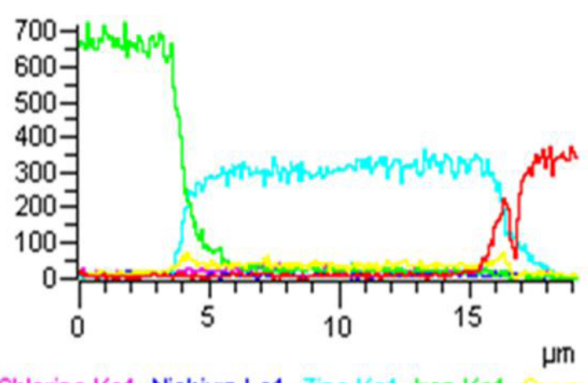

Chlorine Ka1, Niobium La1, Zinc Ka1, Iron Ka1,

(B)

Figura 9: A) Micrografia obtida por FEG da secção transversal de aço eletrozincado polido; B) Espectro de EDS em linha. 
Para a amostra polida embutida em resina acrílica, a avaliação mostra que a espessura e composição química são similares aos resultados para a amostra embutia pós criofraturada. As composições e espessuras semelhantes atestam a reprodutibilidade no preparo das amostras por eletrodeposição. Os parâmetros adotados para a eletrodeposição foram mantidos em todo o presente trabalho, para a deposição do revestimento de zinco com espessura da ordem $10 \mu \mathrm{m}$. A espessura dos revestimentos de zinco também foi avaliada por Espectroscopia de Fluorescência de Raios X (FRX) e confirmaram os resultados obtidos por FEG e EDS.

Após o processo de eletrogalvanização, as superfícies são ativadas por 20 segundos de imersão em solução de ácido nítrico diluído para a remoção de óxidos. O efeito da ativação por imersão, em ácido nítrico diluído, na morfologia da camada de zinco, foi analisado por Microscopia Eletrônica de Varredura de alta resolução (MEV/FEG) e os resultados são apresentados como micrografias para: amostras sem ativação (Figura $10 \mathrm{~A}$ ) e ativada (Figura $10 \mathrm{~B}$ ).
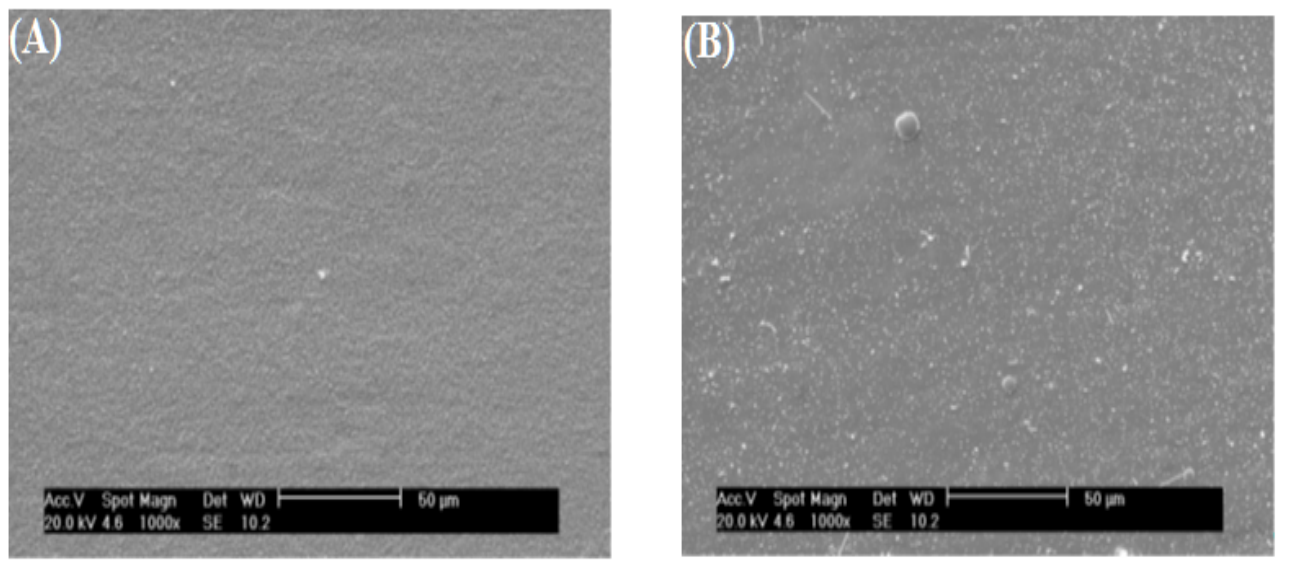

Figura 10: Micrografias obtidas por MEV (aumento 1000X) das superfícies de aço eletrozincado: A) sem ativação e B) com ativação em ácido nítrico (pH 1).

A superfície do aço eletrozincado, após ativação em $\mathrm{HNO}_{3}$, apresenta superfície brilhante, característica do zinco metálico. No entanto, a superfície ativa, reage rapidamente com o oxigênio do meio levando à formação de óxidos e posteriormente produtos de corrosão superficiais do zinco. Os tratamentos de passivação por imersão foram feitos após ativação - energia superficial é maior. 


\subsection{Caracterização das soluções passivadoras}

\subsubsection{Estudo do pH}

A simples imersão de peças de aço eletrozincado em solução de nitrato de cério confere uma melhora, ainda que temporária, em sua resistência à corrosão, sendo o cério o mais protetor dos elementos da série dos lantanídeos, tanto em substrato de aço, como em substrato de alumínio (HINTON, 1992). Como existem inúmeros trabalhos nesta linha, uso de sais de cério, a contribuição original desta tese consiste na proteção do aço eletrozincado por filme misto, constituído por camada orgânica (polimérica ou não) combinada a espécies inorgânicas, especificamente, compostos contendo íons de cério e nióbio.

O aditivo orgânico abrilhantador usado, 2 butino-1,4dial propoxilato, foi escolhido como precursor orgânico por ser de função mista (éter e álcool) e apresentar custo comercial reduzido. Além disso, não foi anteriormente usado como fonte de composto orgânico em sistemas protetores sobre aços eletrozincados. Por se tratar de composto orgânico de função mista, a criação de condições para preparo dos banhos de tratamento, que levem à clivagem do éter por oxidação e formação sequencial de álcoois, cetonas, aldeídos e ácidos carboxílicos, possibilita uma gama variada de produtos, os quais podem interagir diferentemente com o revestimento de zinco.

Ao combinar nitrato de cério hexahidratado e 2 butino-1,4 dial propoxilato em solução contendo nitrato de sódio e sulfato de sódio, a solução final formada é ácida ( $\mathrm{pH} 4$ a 5), sendo que nesta faixa de $\mathrm{pH}$, o zinco é estável na forma solúvel, mas apresenta-se no limiar de estabilidade entre espécies solúveis e insolúveis (solubilidade de zinco no diagrama de Pourbaix). Esta faixa de $\mathrm{pH}$ possibilita a solubilização do zinco e redução de espécies químicas presentes no banho, causando mudança de $\mathrm{pH}$ e processo de deposição. O uso de nitrato de sódio e sulfato de sódio foi a forma encontrada de se criar um meio oxidante, sem que houvesse hidrólise das espécies (sais não hidrolisáveis).

As soluções utilizadas no presente trabalho foram empregadas no sentido de garantir $\mathrm{pH}$ ideal para solubilização do zinco e posterior deposição das espécies de interesse, especificamente íons de cério e de nióbio. Também se procurou configurar uma solução oxidante, representados pela mistura de sulfato 
e nitratos, garantindo assim, a decomposição por oxidação do 2 butino-1,4 diol propoxilato. O diagrama de Pourbaix para o zinco, a faixa de $\mathrm{pH}$ das soluções de tratamentos e as reações almejadas para os compostos inorgânicos são mostradas na Figura 11.

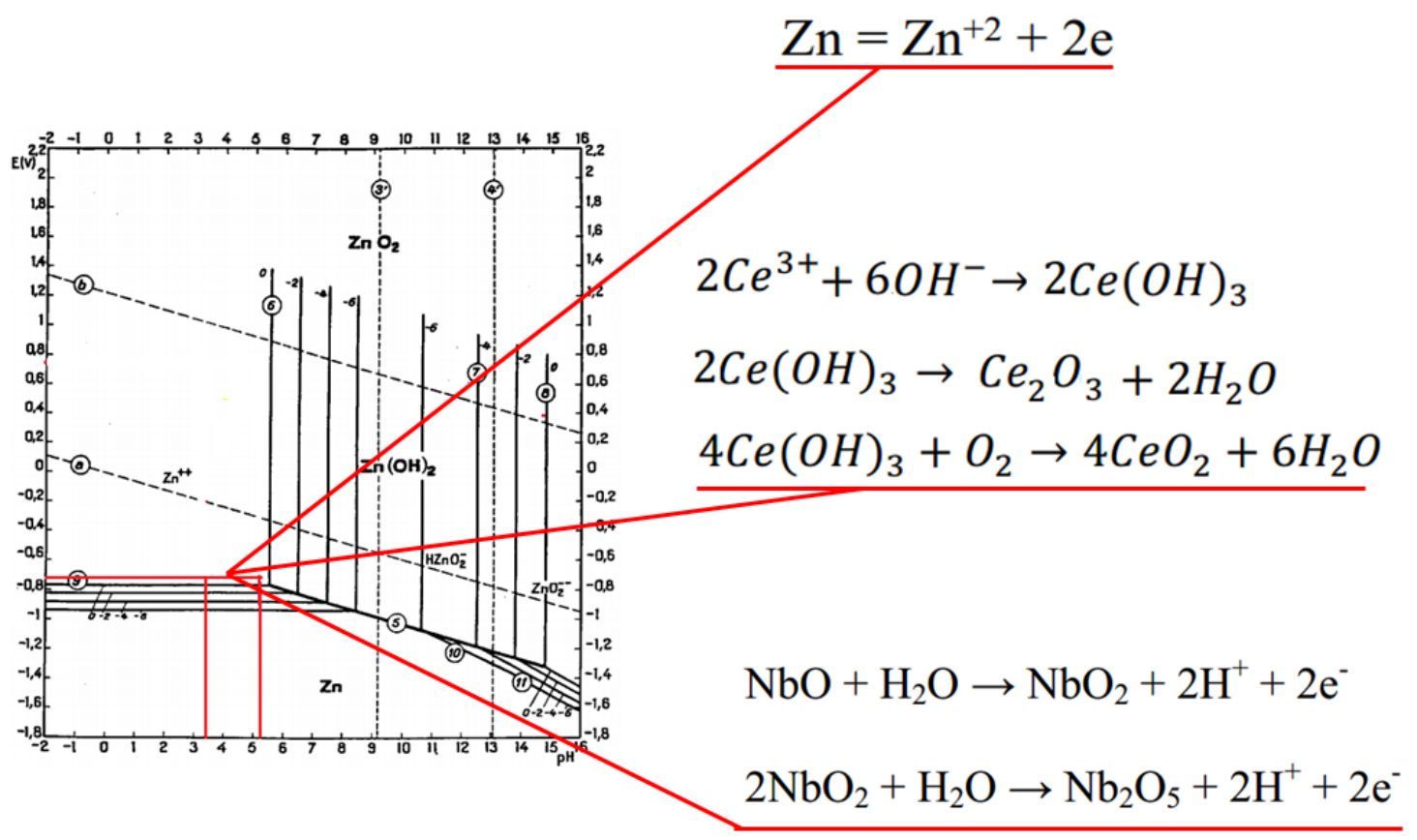

Figura 11: Diagrama de Pourbaix, faixa de $\mathrm{pH}$ das soluções de tratamentos e as reações dos compostos inorgânicos, cério e nióbio.

Um estudo das soluções quanto aos valores de $\mathrm{pH}$ foi realizado para garantia das características adequadas da solução de tratamento, visando possibilitar reações de formação e deposição dos filmes superficiais. A Tabela 3 mostra os valores de $\mathrm{pH}$ dos reagentes precursores e das soluções formadas.

Tabela 3. Valores de pH das soluções de nitrato de cério hexahidratado, sulfato de sódio, nitrato de sódio, 2 butino-1,4 diol propoxilato e da mistura destas soluções formando a solução de tratamento proposta.

\begin{tabular}{rccccc}
\hline $\begin{array}{r}\text { Reagentes } \\
\mathrm{pH}\end{array}$ & $\mathrm{SO}_{4}^{2-}$ & $\mathrm{NO}_{3}$ & $\mathrm{C}_{7} \mathrm{H}_{12} \mathrm{O}_{3}$ & $\mathrm{Ce}\left(\mathrm{NO}_{3}\right)_{3} .6 \mathrm{H}_{2} \mathrm{O}\left(\mathrm{Ce}^{3+}\right)$ & \\
\hline & 5,8 & 6,0 & 4,3 & 4,1 & \\
& $\mathrm{SO}_{4}^{2+}+\mathrm{NO}_{3}$ & $\left(\mathrm{Ce}^{3+}\right)_{+} \mathrm{NO}_{3}$ & $\left(\mathrm{Ce}^{3+}\right)+\mathrm{SO}_{4}^{2 .}$ & $\left(\mathrm{Ce}^{3+}\right)_{+}+\mathrm{NO}_{3}+\mathrm{SO}_{4}^{2 .}$ & $\left(\mathrm{Ce}^{3+}\right)+\mathrm{NO}_{3}+\mathrm{SO}_{4}^{2+}+\mathrm{C}_{7} \mathrm{H}_{12} \mathrm{O}_{3}$ \\
$\mathrm{pH}$ & 5,9 & 4,7 & 4,3 & 4,6 & 4,7 \\
\hline
\end{tabular}


As espécies nitrato de sódio e sulfato de sódio são obtidas pela reação de ácidos e bases fortes, portanto estes sais possuem caráter neutro, não sofrendo hidrólise. O valor mostrado na Tabela 3 para as soluções de nitrato de sódio e sulfato de sódio levemente ácido se deve ao fato destas soluções serem preparadas em meio aerado, causando dissolução de $\mathrm{CO}_{2}$ no meio e acidificação do mesmo. Quando se observa o valor de $\mathrm{pH}$ da solução precursora de cério, $\left(\mathrm{Ce}\left(\mathrm{NO}_{3}\right)_{3} \cdot 6 \mathrm{H}_{2} \mathrm{O}\right)$, este passa de 4,1 para 4,6 com a adição da solução constituída de nitrato de sódio e sulfato de sódio. $\mathrm{O}$ aumento de $\mathrm{pH}$ pode ter sido ocasionado pela redução parcial de nitrato a nitrito em meio ácido segundo a equação:

$$
\mathrm{NO}_{3}{ }^{-}+\mathrm{H}_{2} \mathrm{O}+2 \mathrm{e}^{-} \rightarrow \mathrm{NO}_{2}^{-}+2 \mathrm{OH}^{-}
$$

A adição de 0,05 mol. $\mathrm{L}^{-1}$ de $\mathrm{Ce}\left(\mathrm{NO}_{3}\right)_{3} \cdot 6 \mathrm{H}_{2} \mathrm{O}$ causa variação de $\mathrm{pH}$ de 5,6 para 4,1, o que se deve à forte carga do íon cério e a formação de complexos de cério intermediários e de íons hidrônio $\left(\mathrm{H}_{3} \mathrm{O}^{+}\right)$, segundo as equações:

$$
\begin{aligned}
& \mathrm{Ce}\left(\mathrm{NO}_{3}\right)_{3} \cdot 6 \mathrm{H}_{2} \mathrm{O}+\mathrm{H}_{2} \mathrm{O} \rightarrow \mathrm{Ce}\left(\mathrm{H}_{2} \mathrm{O}\right)_{6}{ }^{3+}+\mathrm{H}_{3} \mathrm{O}^{+} \\
& \mathrm{Ce}\left(\mathrm{H}_{2} \mathrm{O}\right)_{6}{ }^{3+}+\mathrm{H}_{2} \mathrm{O} \rightarrow\left[\mathrm{Ce}\left(\mathrm{H}_{2} \mathrm{O}\right)_{5}(\mathrm{OH})\right]^{2+}+\mathrm{H}_{3} \mathrm{O}^{+}
\end{aligned}
$$

A adição de nitrato de cério hexahidratado causa desprotonação da água e formação de complexos de cério intermediários por hidratação, o que justifica a variação de $\mathrm{pH}$ das soluções de nitrato de sódio e sulfato de sódio, respectivamente de 6,0 e 5,8 e para 4,7 e 4,3, após adição de 0,05 mol..-1 de $\mathrm{Ce}\left(\mathrm{NO}_{3}\right)_{3} \cdot 6 \mathrm{H}_{2} \mathrm{O}$. De forma resumida, pode-se afirmar que o íon cério comporta-se como ácido fraco quando em solução. Portanto, a solubilidade do cério trivalente em meio aquoso é mantido em função do $\mathrm{pH}$, e valores de $\mathrm{pHs}$ mais altos promovem a sua precipitação, como pode ser observado nas equações abaixo:

$$
\begin{aligned}
& \mathrm{Ce}^{3+}+3 \mathrm{OH}^{-} \rightarrow \mathrm{Ce}(\mathrm{OH})_{3} \\
& \mathrm{Ce}(\mathrm{OH})_{3} \rightarrow \mathrm{CeO}_{2}+2 \mathrm{H}_{2} \mathrm{O}
\end{aligned}
$$


A evolução do pH da solução final com nitratos (de cério e de sódio) e sulfato de sódio, além da espécie orgânica 2 butino-1,4 diol propoxilato, foi monitorada desde a sua preparação até sete dias. A variação do pH é creditada à transformação da espécie orgânica e às reações envolvendo a mesma com o meio oxidante, nitrato de sódio e sulfato de sódio. A evolução do $\mathrm{pH}$, em função do tempo de preparação (tempo de reação) a $25^{\circ} \mathrm{C}$, é observada na Figura 12.

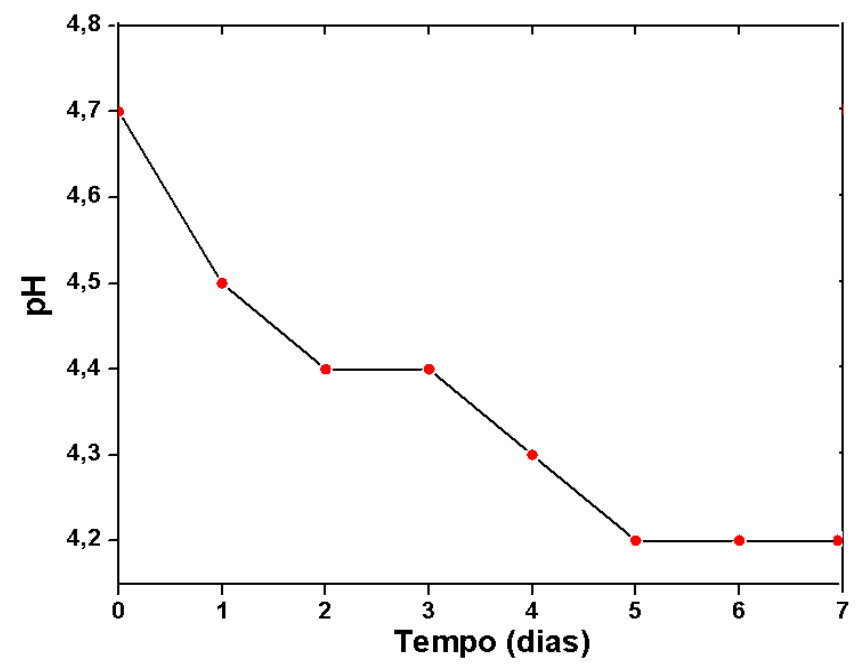

Figura 12: Evolução do $\mathrm{pH}$ em função do tempo desde a preparação da solução de tratamento contendo nitrato de sódio e cério, sulfato de sódio e 2 butino-1,4diol propoxilato.

A adição da espécie orgânica não altera significativamente o pH da solução final de tratamento, de forma a comprometer a presença de íons cério em solução pela sua precipitação, o que ocorre em pHs mais altos. Possivelmente, a diminuição do $\mathrm{pH}$ se deva à evolução do meio reacional, às interações do mesmo com as espécies orgânicas e possíveis produtos orgânicos formados da decomposição do 2 butino-1,4 diol propoxilato. A variação de $\mathrm{pH}$ não é significativa mesmo com a formação de produtos orgânicos a partir da espécie precursora 2 butino-1,4 diol propoxilato, pois da oxidação desta espécie podem surgir álcoois, aldeídos, cetonas e ácidos carboxílicos, com pequena variação da acidez dimensionada por pka.

Os tratamentos por imersão em soluções contendo nitratos de cério e sódio, sulfato de sódio e 2 butino-1,4 diol propoxilato são as primeiras de três etapas de investigação do efeito dos parâmetros de tratamento, no presente 
trabalho. O objetivo desta etapa foi avaliar o tempo mais efetivo para a formação de camada protetora. Após determinação do melhor tempo de tratamento entre os investigados, as amostras passaram para uma segunda etapa de tratamento.

A segunda etapa consistiu na imersão em solução de peróxido de hidrogênio, realizada logo após o tratamento selecionado na primeira etapa como a forma de precipitar íons cério no filme formado na superfície da amostra, e que devido a tempos de imersão pequenos, poderiam não ter precipitado. Scholes (SCHOLES, 2006) descreve o papel do pH para a precipitação quantitativa do cério, nomeado pelo autor como "Regra do peróxido". Os estudos dirigidos nesta etapa buscaram resposta quanto ao tempo ideal de imersão em solução de peróxido de hidrogênio para precipitação mais efetiva de cério e maior proteção contra a corrosão.

Na terceira etapa as amostras, após serem retiradas da solução de peróxido de hidrogênio, foram imersas em soluções contendo os mesmos componentes da etapa um, mas com nitrato de cério hexahidratado sendo substituído por oxalato de nióbio amoniacal (ANO). A Tabela 4 apresenta os valores de $\mathrm{pH}$ das soluções precursoras e da solução de conversão (nitrato de sódio, sulfato de sódio, 2 butino-1,4 diol propoxilato e oxalato de nióbio amoniacal).

Tabela 4: Valores de pH das soluções precursoras e das soluções de conversão.

\begin{tabular}{cccccc}
\hline Reagentes & $\mathrm{SO}_{4}^{2-}$ & $\mathrm{NO}_{3}^{-}$ & $\mathrm{C}_{7} \mathrm{H}_{12} \mathrm{O}_{3}$ & {$\left[\mathrm{NH}_{4}\left[\mathrm{Nb}\left(\mathrm{C}_{2} \mathrm{O}_{4}\right)_{3}\left(\mathrm{H}_{2} \mathrm{O}\right)\right]\left(\mathrm{H}_{2} \mathrm{O}\right)\right]$ (ANO) } \\
$\mathrm{pH}$ & 5,8 & 6,0 & 4,3 & 2,2 & \\
\hline & $\mathrm{SO}_{4}^{2-}+\mathrm{NO}_{3}^{-}$ & $(\mathrm{ANO})+\mathrm{NO}_{3}^{-}$ & $(\mathrm{ANO})+\mathrm{SO}_{4}^{2-}$ & $(\mathrm{ANO})+\mathrm{NO}_{3}^{-}+\mathrm{SO}_{4}^{2-}$ & $(\mathrm{ANO})+\mathrm{NO}_{3}^{-}+\mathrm{SO}_{4}^{2-}+\mathrm{C}_{7} \mathrm{H}_{12} \mathrm{O}_{3}$ \\
$\mathrm{pH}$ & 5,9 & 2,8 & 2,7 & 2,7 & 3,9 \\
\hline
\end{tabular}

Os valores de pH para as soluções de nitrato de sódio e sulfato de sódio, individualmente e quando misturadas, foram as mesmas observadas para o tratamento com nitrato de cério hexahidratado. Quando o 2 butino-1,4 diol propoxilato é adicionado ao oxalato de nióbio amoniacal, nitrato de sódio e sulfato de sódio, ocorre aumento no valor de pH como mostrado no Figura 13. 


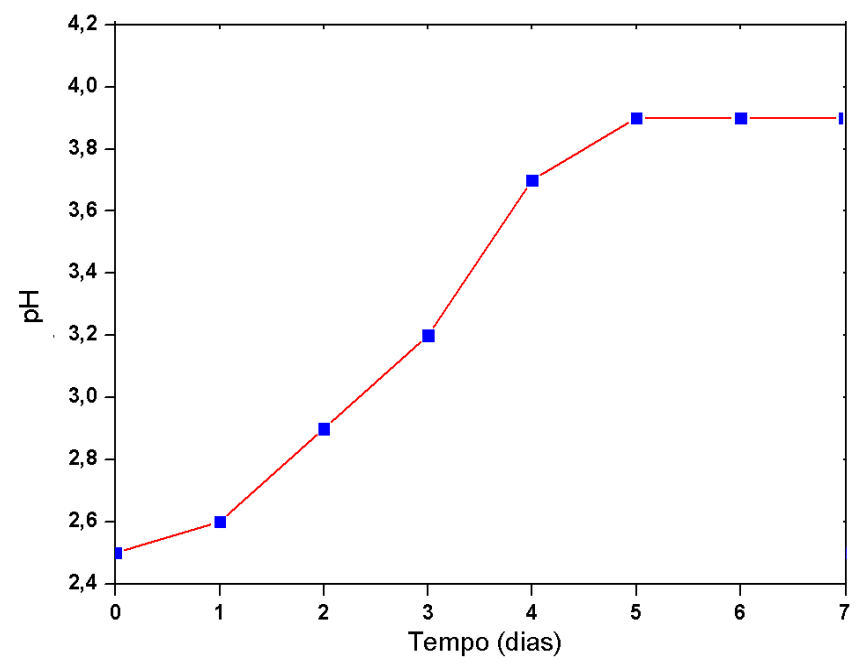

Figura 13: Evolução do $\mathrm{pH}$ em função do tempo desde a preparação da solução de tratamento contendo oxalato de nióbio amoniacal, nitrato de sódio, sulfato de sódio e 2 butino-1,4diol propoxilato.

$\mathrm{O}$ pH final da solução de tratamento à base de nióbio (nitrato de sódio, sulfato de sódio com 2 butino-1,4 diol propoxilato e oxalato de nióbio amoniacal) apresenta, após três dias de preparação $\mathrm{pH}=3,9$. Esta variação no $\mathrm{pH}$ mostra que $\mathrm{o}$ aditivo orgânico pode ter reagido e, como citado anteriormente, os possíveis produtos são de menor acidez.

Em estudos iniciais sobre a proteção a corrosão por soluções contendo apenas oxalato de nióbio amoniacal, o pH mais efetivo entre os testados foi o $\mathrm{pH}=4$, quando comparados a $\mathrm{pH}=3$ e $\mathrm{pH}=7$, para a deposição superficial de nióbio na forma de óxido em aço eletrozincado. Quando testadas soluções com valores de $\mathrm{pH}$ mais altos, caso de $\mathrm{pH}=7$, ocorria precipitação competitiva de espécies (sódio, potássio e fósforo), que foram adicionadas na solução na forma de solução tamponante, (FERREIRA JR, 2012).

A metodologia adotada teve como finalidade criar uma solução de tratamento contendo íons de cério e composto orgânico de função mista (éter e álcool) para obtenção de um revestimento efetivo contra a corrosão. Hipóteses relacionadas às espécies orgânicas presentes no filme formado e a possibilidade de polimerização destas será ressaltada no decorrer deste trabalho, mais especificamente nos resultados de FTIR obtidos das amostras tratadas por imersão em solução contendo nitrato de cério hexahidratado, sulfato de sódio, nitrato de sódio e 2 butino-1,4 diol propoxilato (tratamentos T1, T10 e T20). 


\subsubsection{Espectroscopia no Infravermelho por Transformada de Fourier}

De acordo com os resultados ou valores de $\mathrm{pH}$ apresentados anteriormente, as soluções, tanto as que contêm íons cério quanto as que contêm íons de nióbio, em sua constituição final com 2 butino-1,4diol propoxilato, sulfato de sódio e nitrato de sódio apresentaram estabilidade depois de sete dias e, portanto, depois de preparadas as soluções foram utilizadas após este período. A Figura 13 apresenta o Espectro no Infravermelho para as soluções de tratamento contendo sais de cério e sais de nióbio, soluções de conversão propostas no presente trabalho, com absorbância normalizada em função do número de onda.

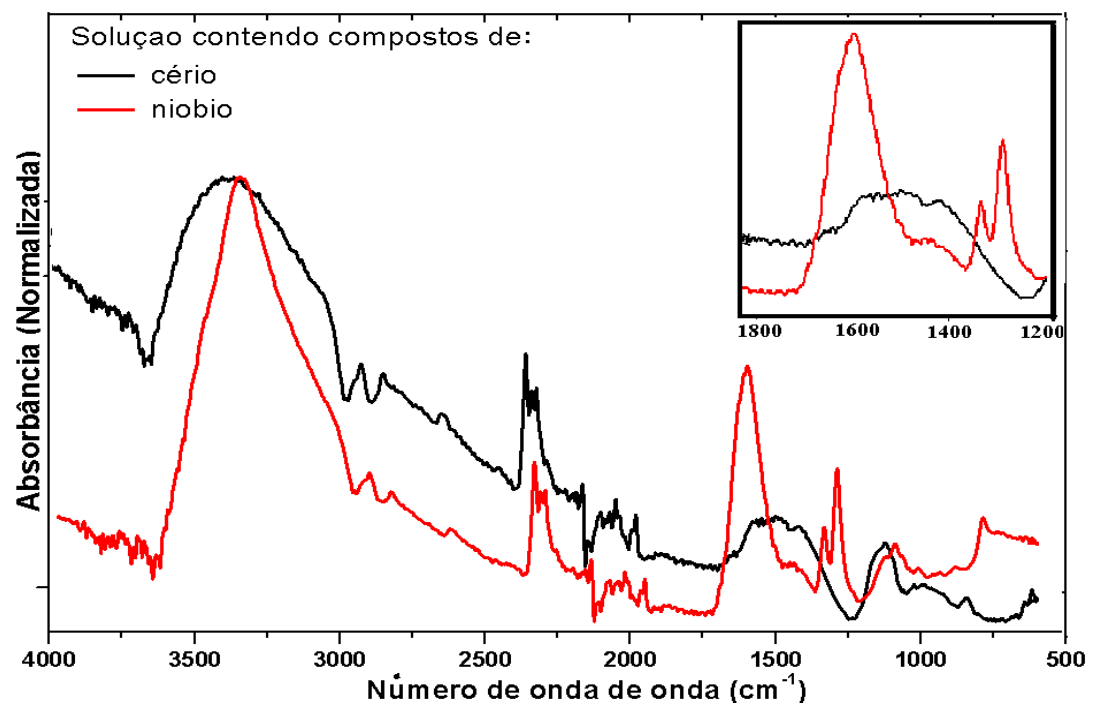

Figura 13: Espectros FTIR para soluções contendo compostos de cério e de nióbio com: nitrato de sódio, sulfato de sódio e 2 butino1, 4 diol propoxilato.

Os espectros permitem observar a presença de diferentes picos entre 1400 $\mathrm{cm}^{-1}-900 \mathrm{~cm}^{-1}$, região conhecida como "impressão digital", permitindo afirmar que as soluções contendo compostos de sais de cério e sais de nióbio apresentam compostos orgânicos diferentes. Picos observados apenas para solução contendo composto de nióbio $\left(790 \mathrm{~cm}^{-1}, 884 \mathrm{~cm}^{-1}, 1288 \mathrm{~cm}^{-1}, 1336 \mathrm{~cm}^{-1}, 1593 \mathrm{~cm}^{-1}\right)$ e para soluções contendo composto de cério $\left(615 \mathrm{~cm}^{-1}, 845 \mathrm{~cm}^{-1}, 1494 \mathrm{~cm}^{-1}, 2850 \mathrm{~cm}^{-1} \mathrm{e}\right.$ $2927 \mathrm{~cm}^{-1}$ ) servem como forma de diferenciação entre as soluções com estes diferentes modos vibracionais, podendo estar relacionados à presença dos elementos cério ou nióbio. 
Os espectros vibracionais no infravermelho mostram bandas largas entre $3500 \mathrm{~cm}^{-1}-3000 \mathrm{~cm}^{-1}$, correspondentes ao estiramento do grupo hidroxila $(-\mathrm{OH})$, devido à presença de água (soluções). O estreitamento nesta faixa, observado pelo pico da amostra contendo composto de nióbio, centrado em $3340 \mathrm{~cm}^{-1}$ corresponde ao estiramento $\mathrm{Nb}-\mathrm{OH}$. A presença deste tipo de ligação, entre nióbio e grupo hidroxila, pode ser observada também pelas bandas de absorção entre $1700 \mathrm{~cm}^{-1}-1500 \mathrm{~cm}^{-1} 1$, referentes à deformação angular desta ligação (BRANDÃO, 2009).

Os picos nas regiões entre $950 \mathrm{~cm}^{-1}-840 \mathrm{~cm}^{-1}$ e $700 \mathrm{~cm}^{-1}-600 \mathrm{~cm}^{-1}$ correspondem, respectivamente, ao estiramento da ligação $\mathrm{Nb}=\mathrm{O}$ e $\mathrm{Nb}-\mathrm{O}-\mathrm{Nb}$ (HUANG, 1999). Picos específicos observados em $1085 \mathrm{~cm}^{-1}$ e $1125 \mathrm{~cm}^{-1}$ foram relatados como diferentes estiramentos das ligações $\mathrm{Nb}-\mathrm{O}$ do composto $\mathrm{Nb}_{2} \mathrm{O}_{5}$, quando em presença de ácido nítrico (BRANDÃO, 2009).

Para o elemento cério, na forma química de óxido e nitrato, são relatados como modos vibracionais observados, respectivamente, em $610 \mathrm{~cm}^{-1}$ e $2850 \mathrm{~cm}^{-1}$. No entanto, devido à dificuldade em referenciar $\mathrm{CeO}_{2}$, esta referência será usada apenas para confirmar a presença de cério na forma de óxido trivalente, $\mathrm{Ce}_{2} \mathrm{O}_{3}$ (LI, 1989, SIOKOU, 1999, WANG, 2008).

A presença de picos, para ambos os espectros, localizados em $815 \mathrm{~cm}^{-1}$ ($\left.\mathrm{CH}_{3}\right), 992 \mathrm{~cm}^{-1}\left(\mathrm{CH}_{2}-\right), 1120 \mathrm{~cm}^{-1}\left(-\mathrm{CH}_{3}\right), 1980 \mathrm{~cm}^{-1}$ e $2120 \mathrm{~cm}^{-1}(\mathrm{H}-\mathrm{C}=\mathrm{O})$, mostra que as soluções possuem estes compostos orgânicos e que estes são produtos da reação de 2 butino-1,4 diol propoxilato com espécies oxidantes do meio reacional (SOCRATES, 1994). Os picos em $1100 \mathrm{~cm}^{-1} \mathrm{e} 1220 \mathrm{~cm}^{-1}$ estão relacionados à ligação entre carbono e oxigênio (C-O) e à ligação entre carbono, oxigênio e hidrogênio (C-O-H), cujo pico corresponde ao estiramento das ligações do grupo carboxil (COO'). Este grupo esta ausente no composto orgânico usado inicialmente (2 butino-1,4 diol propoxilato).

Picos presentes em $1100 \mathrm{~cm}^{-1}, 1220 \mathrm{~cm}^{-1} \mathrm{e} 1362 \mathrm{~cm}^{-1}$ confirmam a presença do grupo carbonila (WANG, 1995, AUINAT, 2005) e são definidas como bandas de absorção fracas. Uma banda de absorção centrada entre $1655 \mathrm{~cm}^{-1}$ $1630 \mathrm{~cm}^{-1}$ para ambas as soluções e correspondente ao estiramento do grupo 
orgânico alceno $(\mathrm{C}=\mathrm{C})$ é observada. Também é possível observar bandas de absorção de espécies, entre $1850 \mathrm{~cm}^{-1} \mathrm{e} 1630 \mathrm{~cm}^{-1}$, correspondentes ao grupo carbonila, que não são totalmente separadas (SOCRATES, 1994).

A presença dos picos relatados permite afirmar que partes da molécula orgânica precursora estão presentes nas soluções de cério e de nióbio e que, provavelmente, tenham se originado de reação de oxidação e decomposição de 2 butino-1,4 diol propoxilato. A presença de modos vibracionais correspondentes ao grupo funcional carboxil, para as soluções contendo compostos de cério e compostos de nióbio, permite a elaboração de hipóteses para vias reacionais. Nestas vias, pode ocorrer formação de dois compostos orgânicos diferentes, que podem atuar como precursores poliméricos durante o processo de imersão da peça metálica (aço eletrozincado) na solução de tratamento. A hipótese de duas vias reacionais, a partir do 2butino-1, 4 diol propoxilato são apresentadas nas Figuras 14 e 15.
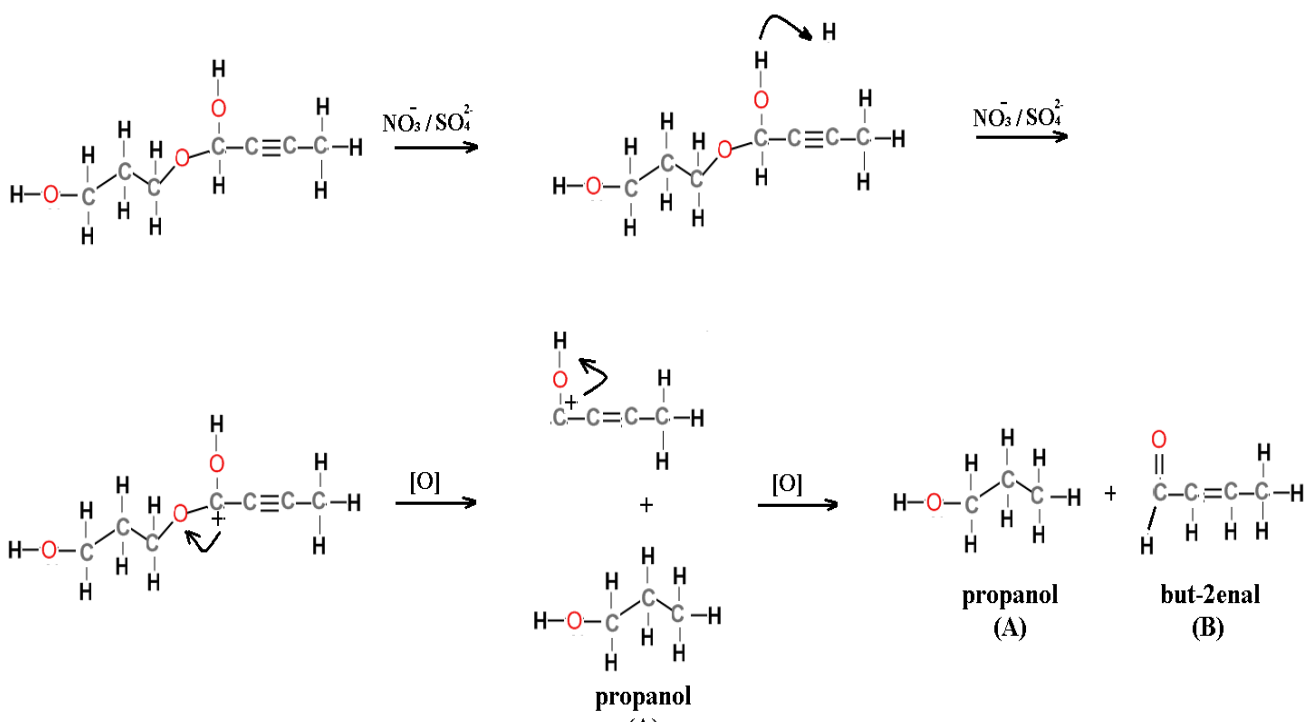

(A)

Figura 14: Representação estrutural de uma via reacional proposta para 2 butino1,4 diol propoxilato em meio oxidante (nitrato e sulfato).

A utilização de nitrato e sulfato foi a forma encontrada de criar um meio oxidante e que tivesse fácil controle de $\mathrm{pH}$, sem adição de solução tampão, por serem estas espécies não hidrolisáveis. O meio oxidante permite clivagem do éter e formação de carbocátion com a formação de um álcool primário e eventual 
formação de um aldeído. Sabe-se que álcoois sofrem oxidação simplesmente pela presença de oxigênio atmosférico, se transformando em aldeídos e, estes, sequencialmente se oxidam a ácidos carboxílicos (KOTZ, 2005). A formação de ácidos carboxílicos provenientes de reações sequenciais de oxidação de 2Butino-1,4-diol propoxilato é mostrada na Figura 15.

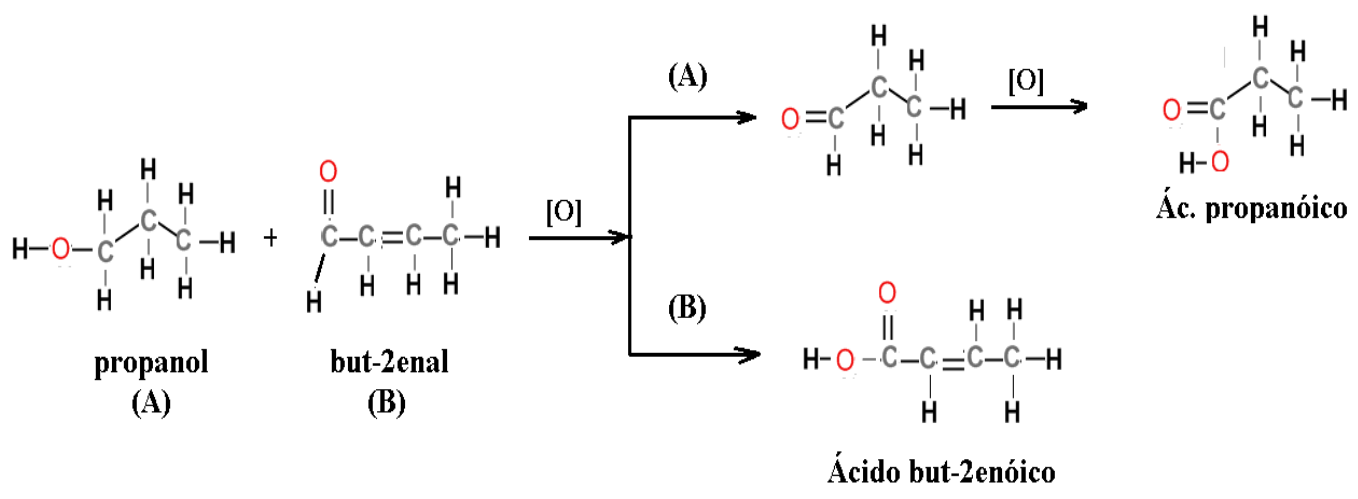

Figura 15: Representação, fórmulas estruturais, de vias reacionais propostas para oxidação de propanol (álcoois) e aldeídos até a formação de ácidos carboxílicos. Os reagentes A e B correspondem aos produtos finais indicados na Figura 14.

Os resultados de FTIR permitem concluir que as soluções preparadas são constituídas por compostos orgânicos, diferentes da espécie inicial 2 butino-1,4 diol propoxilato, devido à ausência de modo vibracional correspondente ao grupo alcino e devido à presença dos picos referentes a carboxilatos, nas soluções contendo composto de cério ou de nióbio e que contém estes elementos provavelmente na forma de complexos. Para determinar a fórmula estrutural de uma substância orgânica partindo de espectros FTIR é preciso calcular o Índice de Deficiência de Hidrogênio (IDH), que indica a ausência ou presença de ligações duplas, triplas ou anéis na estrutura molecular. O cálculo do IDH é feito utilizando a expressão:

$$
\mathrm{IDH}=(\mathrm{C}-\mathrm{M} / 2)+\mathrm{T} / 2+1
$$

onde: $\mathrm{C}$ é o número de átomos de carbono; $\mathrm{M}$ é o número de átomos monovalentes, e T é o número de átomos trivalentes. Pelas regras definidas por 
Kleman, (KLEMAN, 1995), com base na comparação entre as fórmulas da substância desconhecida e o correspondente hidrocarboneto saturado (alcano), é necessário substituir todos os átomos monovalentes (halogênios) por hidrogênio; desconsiderar os átomos bivalentes (oxigênio e enxofre); excluir os átomos trivalentes junto com um hidrogênio (nitrogênio como $\mathrm{NH}$ e fósforo como $\mathrm{PH}$ ), e comparar com a fórmula geral dos hidrocarbonetos saturados $\left(\mathrm{C}_{n} \mathrm{H}_{2 n+2}\right)$. Os valores de IDH para o ácido propanóico e ácido but-2enóico são 0 e 1 , associadas, respectivamente, a alcanos e alcenos, portanto, estão de acordo com as presenças de $-\mathrm{CH}_{2} \mathrm{e}-\mathrm{CH}$.

Segundo os resultados de FTIR e monitoramento dos valores de $\mathrm{pH}$, é possível afirmar que as soluções contendo compostos de cério ou de nióbio, propostos no presente trabalho, são constituídas por ácidos carboxílicos, saturados (propanóico) e/ou insaturados (but-2enóico), com cério e nióbio em solução na forma de complexos solúveis.

\subsection{Tratamentos de proteção da superfície de aço eletrozincado}

Os resultados dos tratamentos de proteção do aço eletrozincado, objetivo principal do presente trabalho, serão apresentados segundo três linhas investigativas:

(1) Efeito do tempo de imersão (1, 10 e 20 minutos) correspondente aos tratamentos T1, T10 e T20, respectivamente em solução de nitrato de cério hexahidratado, nitrato de sódio, sulfato de sódio e 2 butino-1,4 diol propoxilato.

(2) Efeito do tempo de imersão das amostras com tratamento T10 em solução de peróxido de hidrogênio por 1,10 e 20 minutos, tratamentos chamados respectivamente de T10_1, T10_10 e T10_20.

(3) Efeito do tempo de imersão das amostras com os tratamentos T10_10 por 1, 10 e 20 minutos, em solução constituída por oxalato de nióbio amoniacal (ANO), nitrato de sódio, sulfato de sódio, e 2 butino-1,4 diol propoxilato, respectivamente. Tratamentos T10_10_1, T10_10_10 e T10_10_20. 
As técnicas de caracterização empregadas, no presente trabalho, foram adotadas com o objetivo de responder às seguintes questões:

1) O tratamento por imersão em solução de 2-butino-1,4 diol propoxilato, nitrato de cério hexahidratado, nitrato de sódio e sulfato de sódio possibilita a formação de uma camada orgânica sobre o substrato de aço galvanizado?

2) A solução resultante (mistura de 2-butino-1,4 diol propoxilato com nitrato de cério hexa hidratado) é eficiente na deposição de cério no revestimento formado?

3) A camada ou revestimento formado por imersão promove uma diminuição da cinética corrosiva?

Nas seções seguintes, procurar-se-á responder a essas questões.

\subsubsection{Efeito do tempo de imersão em solução contendo cério}

5.3.1.1. Morfologia (Microscopias de Emissão, Microscopia Óptica tridimensional) e Difração de raios $X$.

As micrografias obtidas por microscopia eletrônica de varredura de emissão (FEG) com $1000 \mathrm{X}$ de aumento, para amostras com camada de conversão de cromato, usada como padrão de referência, e com tratamento T1 são apresentadas na Figura 16, A e B, respectivamente.
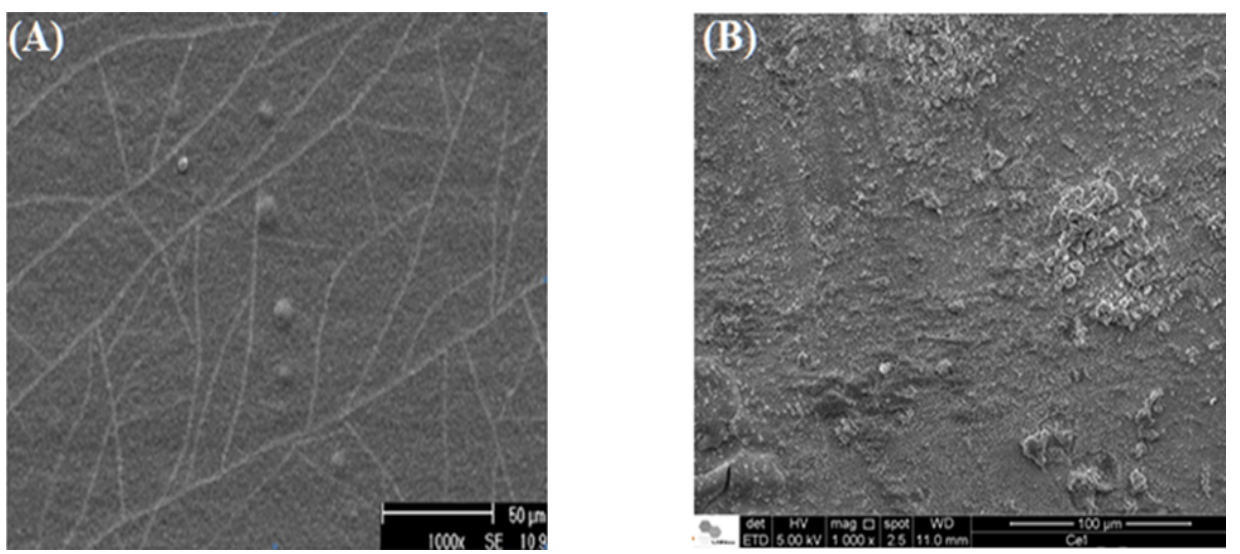

Figura 16: Micrografias obtidas por FEG para amostras eletrozincadas: (A) com camada de conversão de cromato e (B) após tratamento T1. 
A camada de conversão de cromato (CCC) apresenta trincas em toda sua extensão, o que é uma caracteristica deste tipo de camada. Estas trincas são formadas por tensões geradas durante o processo de secagem (CAMPESTRINI, 2002, CHO, 2007 e MARTYAK, 1994). A micrografia da amostra com tratamento T1 apresenta defeitos em toda a sua extensão. Em algumas partes de sua superfície há a possível formação de filme de baixa aderência. As micrografias com aumento de $1000 \mathrm{X}$, obtidas por Microscopia Eletrônica de alta Resolução (FEG) para as com os tratamentos T10 e T20 são apresentadas na Figura 17, A e $\mathrm{B}$, respectivamente.
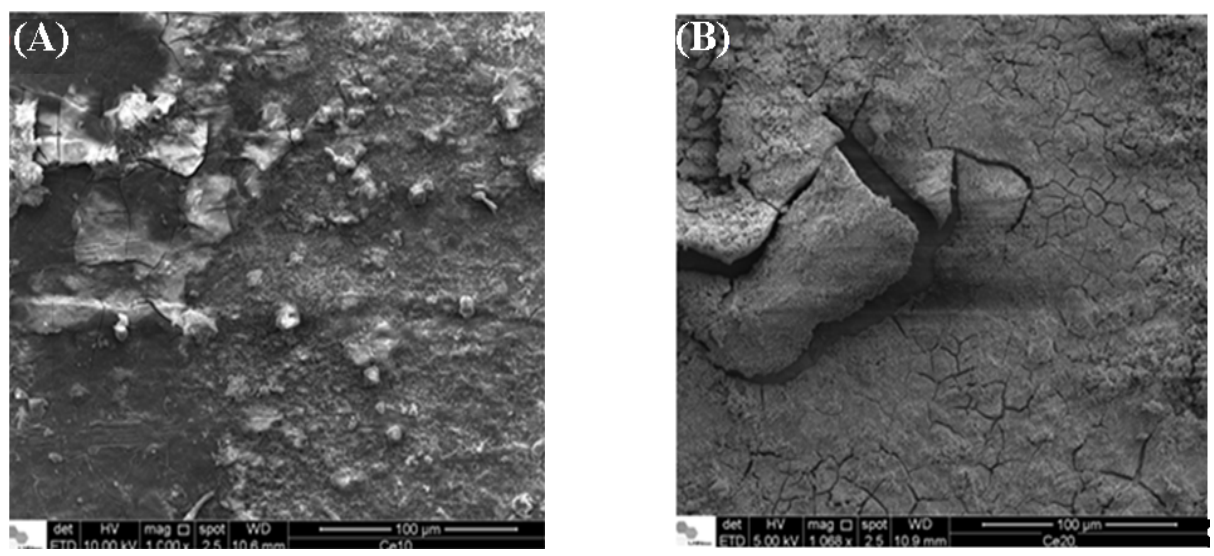

Figura 17: Micrografias obtidas por FEG $(1000 \mathrm{X})$ para as amostras com tratamentos em: A) T10 e B) T20, correspondentes a imersão da peça eletrozincada, respectivamente, por 10 e 20 minutos em solução de nitrato de cério hexahidratado, 2 butino-1,4 diol propoxilato, nitrato sódio e sulfato de sódio.

As micrografias das superfícies com tratamentos T10 e T20 evidenciaram a presença de defeitos em grandes áreas da superfície, com possível exposição do substrato (zinco metálico) e maior susceptibilidade à corrosão. Fica evidente que os defeitos gerados pelos tratamentos propostos T1, T10 e T20 são maiores e mais generalizados que os defeitos apresentados pelo tratamento de conversão de cromato e que o aumento do tempo de imersão em solução de tratamento contendo cério é diretamente proporcional à quantidade de defeitos superficiais.

Quando a amostra é imersa na solução proposta de cério, nitrato de sódio, sulfato de sódio e aditivo orgânico 2 butino-1,4 diol propoxilato, há um ataque da solução ao substrato e solubilização de zinco que, para tempos maiores, caso de 
20 minutos (T20), leva à formação de produtos de corrosão de zinco fracamente ligados à superfície de zinco. $\mathrm{O}$ tratamento por 1 minuto de imersão (T1) mostrouse insuficiente na formação de filme com espessura suficiente para proteção significativa à corrosão, possivelmente por ser um tempo insuficiente para solubilização de zinco e deposição de espécies da solução de tratamento. Portanto, ainda que apresente defeitos numerosos e de extensão significativa, o tempo mais efetivo, dentre os tempos testados, foi de 10 minutos (T10).

Como forma de avaliar a condição de uniformidade da superfície e efeito do tratamento na rugosidade superficial, esta foi avaliada por Microscopia Ótica utilizando imagens tridimensionais por microscopia óptica com aumento de 50. As imagens são apresentadas na Figura 18, para a superfície com tratamento T1.
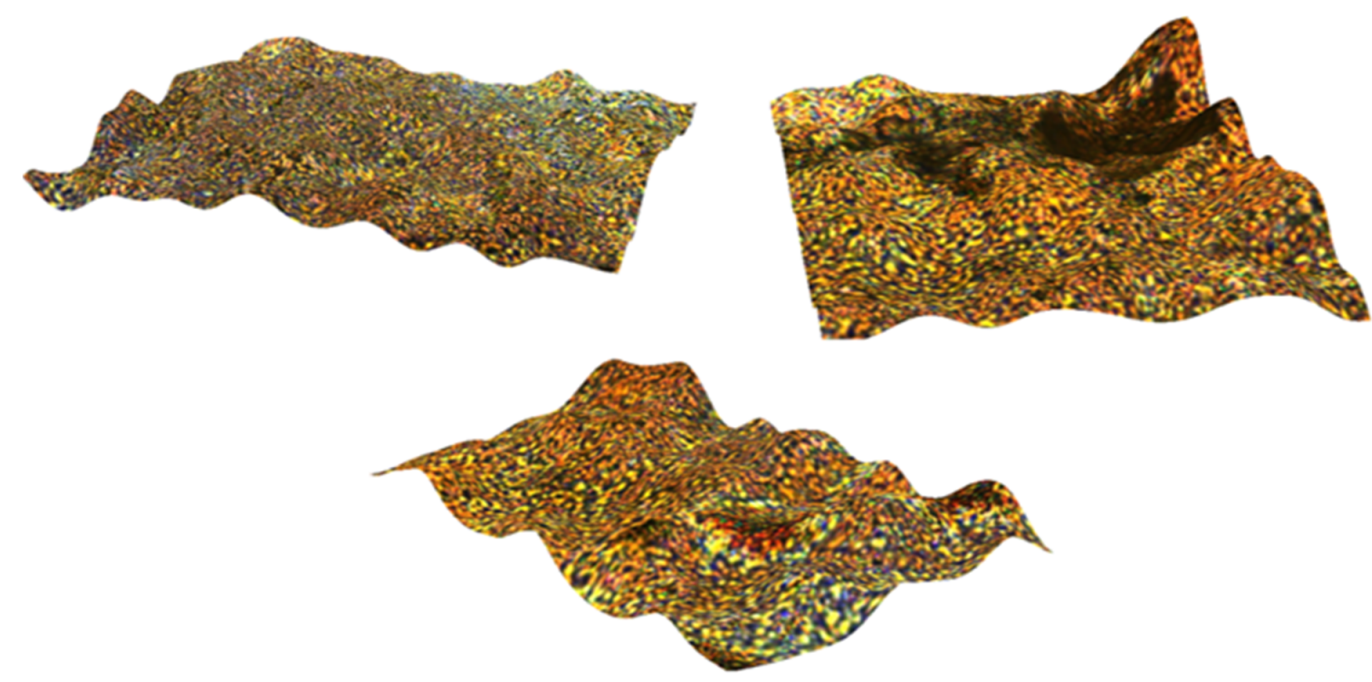

Figura 18: Imagens tridimensionais obtidas por microscópio ótico, aumento $50 \mathrm{X}$, da superfície com tratamento T1 (1 minuto em solução contendo nitrato de cério hexahidratado, de 2-Butino-1,4-diol propoxilato, nitrato de sódio e sulfato de sódio).

As imagens ópticas tridimensionais mostram defeitos pouco acentuados, baixa profundidade e certa uniformidade na distribuição espacial dos mesmos. A repetição de vales superficiais está associada à reflexão difusa da luz em regiões de maior profundidade. Estes vales são equivalentes a poros enquanto regiões escuras (sem reflexão) são defeitos em profundidade. Para efeito comparativo, imagens tridimensionais com 50 vezes de aumento também foram obtidas para 


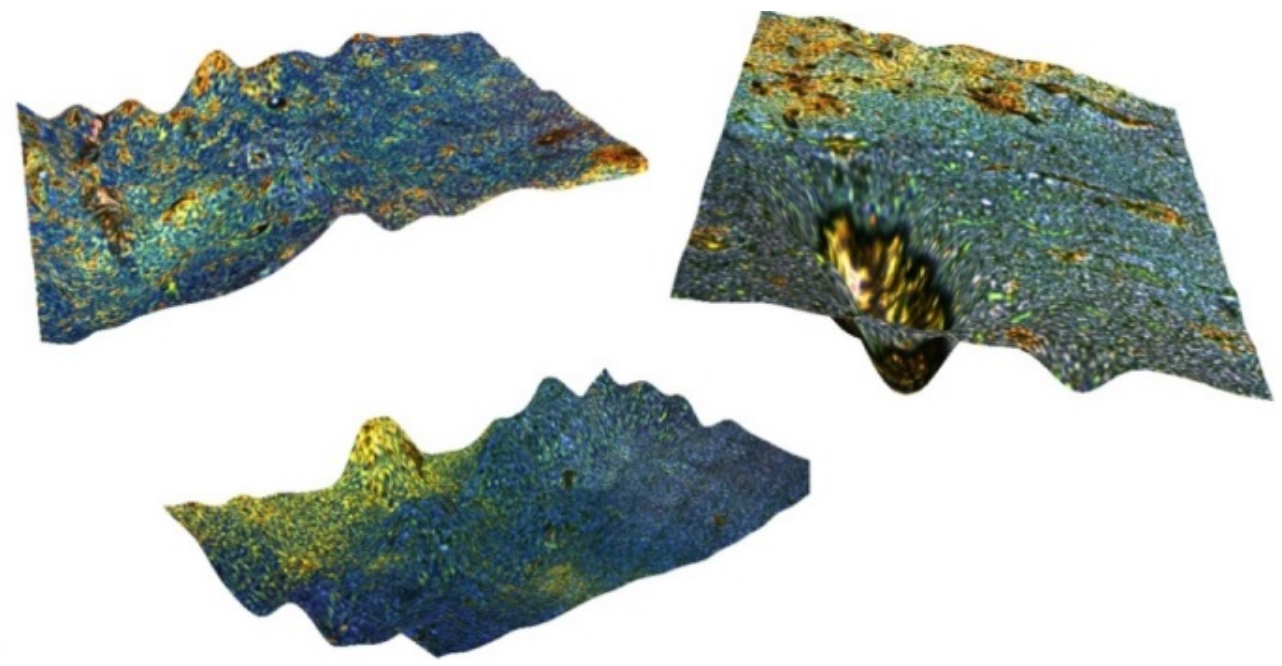

Figura 19: Imagens tridimensionais obtidas por microscópio ótico, aumento $50 \mathrm{X}$, da superfície com tratamento T10 (10 minutos em solução contendo nitrato de cério hexahidratado, de 2-Butino-1,4-diol propoxilato, nitrato de sódio e sulfato de sódio).

As imagens tridimensionais para a superfície T10 evidenciam superfície com número e tamanho de defeitos maiores, pontuais e de maior extensão, porém menos distribuídos, quando comparados a T1.

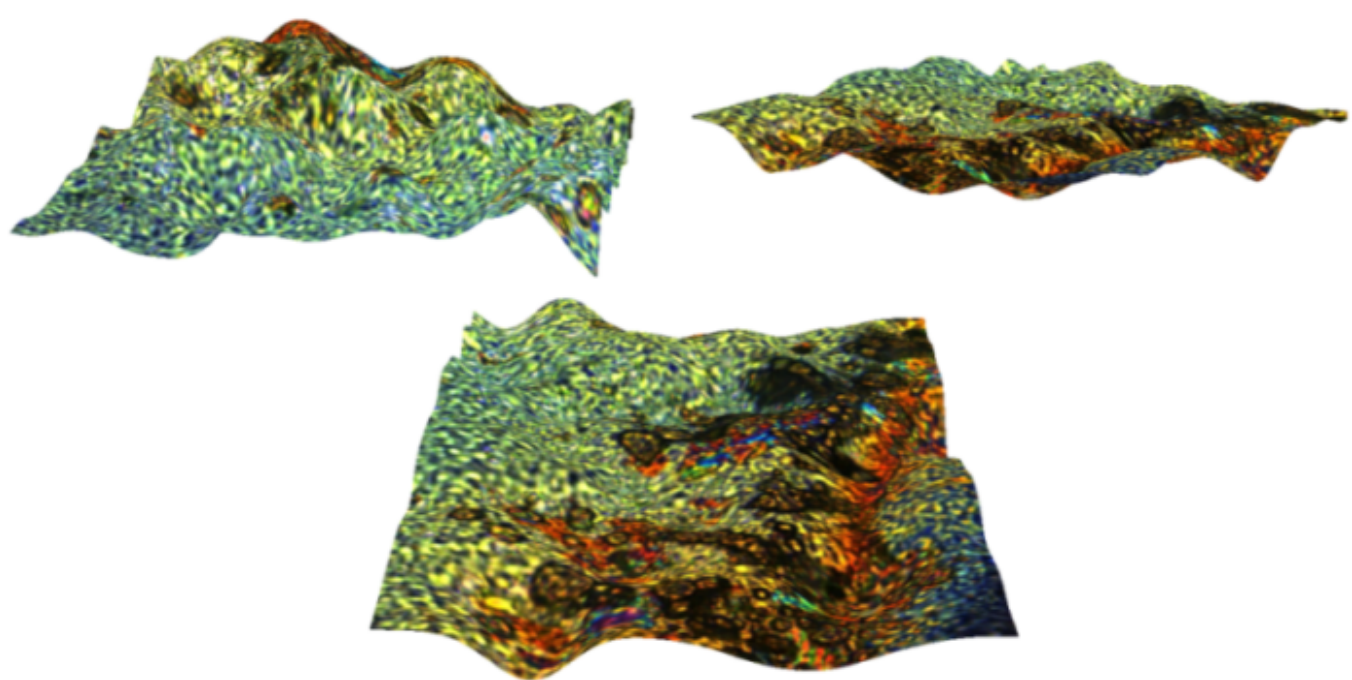

Figura 20: Imagens tridimensionais obtidas por microscópio ótico, aumento $50 \mathrm{X}$, da superfície com tratamento T20 (20 minutos em solução contendo nitrato de cério hexahidratado, de 2-Butino-1,4-diol propoxilato, nitrato de sódio e sulfato de sódio). 
Nas imagens tridimensionais correspondentes às superfícies com os três tratamentos, T1, T10 e T20, foi possível observar o aumento na porosidade e magnitude dos defeitos com o tempo de imersão. A porosidade para este tipo de superfície (zinco) muito provavelmente se deve a formação de hidróxidos, produtos iniciais da corrosão do zinco, mais evidente após 20 minutos em solução contendo cério (T20).

A caracterização morfológica das superfícies tratadas por imersão em diferentes tempos, em solução de conversão contendo nitrato de cério, nitrato de sódio, sulfato de sódio e 2 butino-1,4 diol propoxilato, possibilitou concluir que houve solubilização de zinco e formação de revestimento na superfície. A solução de tratamento, com $\mathrm{pH}=4$, forma uma camada defeituosa. Entre os tempos testados, o tempo para melhor relação defeitos/densificação foi apresentado pelo tratamento T10 (10 minutos de imersão) com base na observação das superfícies tratadas, por microscopia ótica tridimensional.

O aumento de irregularidades e/ou defeitos superficiais é, em geral, um fenômeno observado na deposição a partir de soluções salinas, onde a ampliação dos mesmos se torna mais intensa à medida que a taxa de deposição aumenta e a concentração dos íons, em solução, diminui.

A deposição é mais rápida nas elevações de menor região difusional entre a superfície, onde a deposição ocorre, e o plano externo da camada de difusão, reentrância, e também porque no topo das elevações, as condições de difusão são aproximadas daquelas de maior campo difusional.

O aumento no número de defeitos (trincas e poros) com o tempo de imersão pode também ter sido causado pelo aumento da tensão superficial de cisalhamento, proporcional à espessura do filme formado, durante o processo de secagem. A superfície das amostras com os tratamentos T1, T10 e T20, foram analisadas por Difração de raios $X(D R X)$ e os difratogramas obtidos são apresentados na Figura 21. 


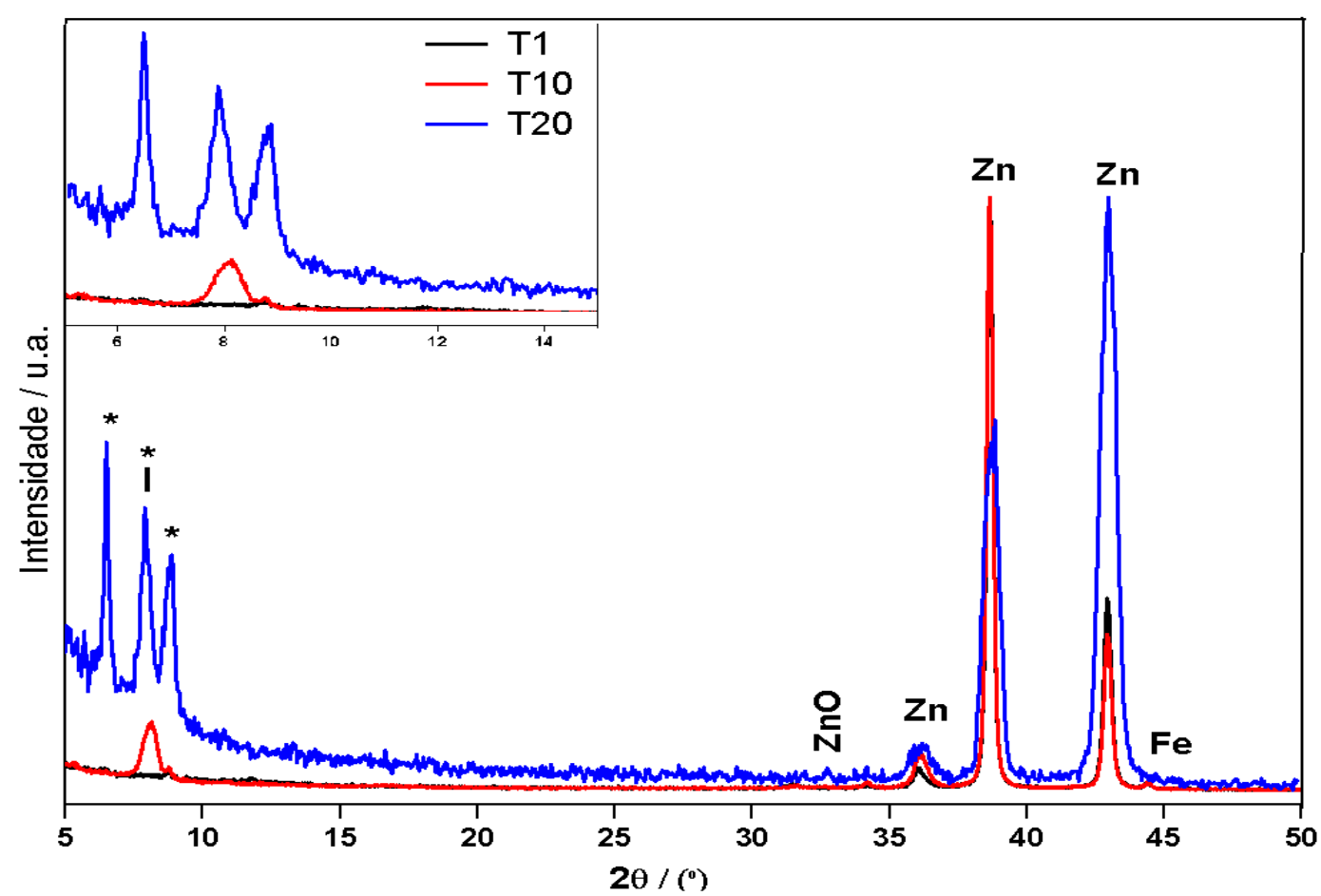

Figura 21: Difratograma obtido por difração de raios X (XRD) das superfícies com os tratamentos T1, T10 e T20, respectivamente, imersas por 1, 10 e 20 minutos em solução de tratamento contendo cério.

Os resultados obtidos por difração de raios $X(D R X)$, representados pelos difratogramas sobrepostos das amostras com diferentes tratamentos T1, T10 e T20, mostram a presença de fases cristalográficas do substrato. Estas fases são características de zinco e de óxido de zinco entre $30^{\circ}$ e $45^{\circ}$. Alguns picos não puderam ser identificados em baixo ângulo. A presença destes picos muito provavelmente está relacionada à presença de espécies orgânicas que apresentam celas unitárias grandes e que podem conter cério, fases não identificadas no difratograma entre $5^{\circ}$ e $10^{\circ}$. A não identificação destas fases dirigiu o trabalho para a obtenção de difratogramas por difração em ângulo rasante e os resultados sugeriram que, os picos referem-se às fases do substrato, óxido de zinco e picos mostrados entre $5^{\circ}$ e $10^{\circ}$ não identificados.

Embora os resultados de Difração de raios $X$ sejam inconclusivos quanto à presença de cério e a possibilidade de deposição do mesmo, ainda assim os resultados foram adotados como evidência da formação de camada orgânica ligada ao substrato, de maior espessura em função do tempo de tratamento. 
5.3.1.2 Análise da composição química (Espectroscopia no Infravermelho por Transformada de Fourier e Espectroscopia Fotoeletrônica de Raios X).

A interpretação dos espectros obtidos no infravermelho foi feita pelo perfil de espectro com a constatação de bandas características de grupos funcionais, como $\mathrm{C}=\mathrm{O}\left(1800 \mathrm{~cm}^{-1}\right.$ a $\left.1600 \mathrm{~cm}^{-1}\right), \mathrm{OH}\left(3500 \mathrm{~cm}^{-1}\right.$ a $\left.3200 \mathrm{~cm}^{-1}\right)$, banda larga para $\mathrm{OH}$ de ácidos $\left(3400 \mathrm{~cm}^{-1}\right.$ a $\left.2700 \mathrm{~cm}^{-1}\right), \mathrm{C}-\mathrm{O}\left(1300 \mathrm{~cm}^{-1}-1000 \mathrm{~cm}^{-1}\right), \mathrm{C}-\mathrm{H}$ alifáticos saturados $\left(3000 \mathrm{~cm}^{-1}-2800 \mathrm{~cm}^{-1}\right),=\mathrm{C}-\mathrm{H}$ insaturados $\left(3100 \mathrm{~cm}^{-1}-3300\right.$ $\mathrm{cm}^{-1}$ ) entre outros (PAVIA, 2010). As superfícies com os tratamentos T1, T10 e T20 foram analisadas por Espectroscopia no Infravermelho por Transformada de Fourier (FTIR) e os espectros são apresentados na Figura 22.

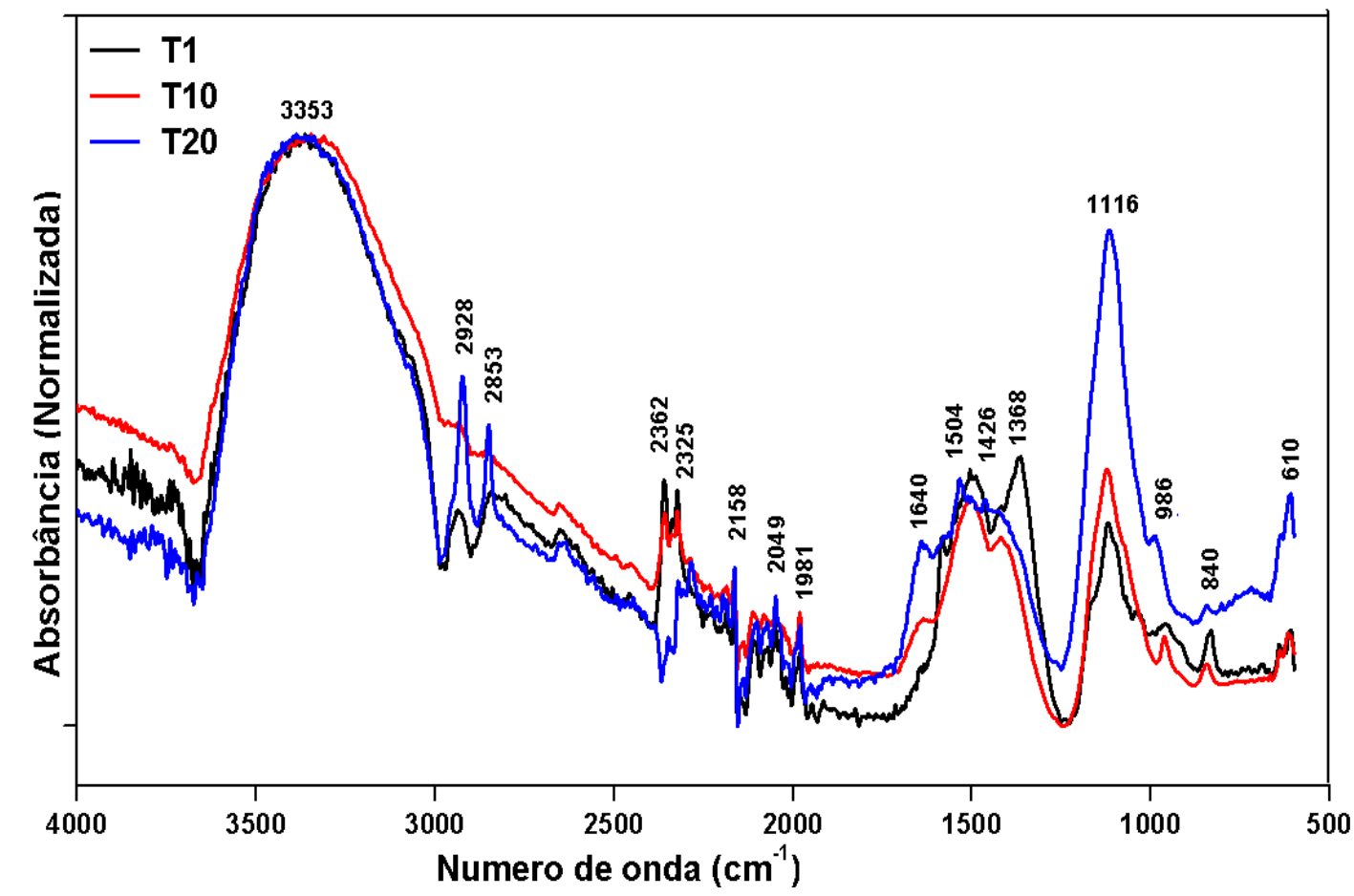

Figura 22: Espectros normalizados de FTIR das superfícies com os tratamentos T1, T10 e T20 sobre aço eletrozincado.

Os espectros apresentaram a maioria dos picos correspondentes, presentes em todos os espectros, com bandas em $610 \mathrm{~cm}^{-1}, 815 \mathrm{~cm}^{-1}, 850 \mathrm{~cm}^{-1}$, $1120 \mathrm{~cm}^{-1}, 1360 \mathrm{~cm}^{-1}, 1400 \mathrm{~cm}^{-1}, 1500 \mathrm{~cm}^{-1}, 1650 \mathrm{~cm}^{-1}, 1980 \mathrm{~cm}^{-1}, 2120 \mathrm{~cm}^{-1}$, $2325 \mathrm{~cm}^{-1}, 2650 \mathrm{~cm}^{-1}, 2850 \mathrm{~cm}^{-1}, 2939 \mathrm{~cm}^{-1}, 3400 \mathrm{~cm}^{-1}$. Os resultados comprovam que o filme formado apresenta a mesma constituição química para os diferentes tempos de imersão. 
Ocorrem variações nas intensidades destes picos, sendo algumas diretamente proporcionais ao tempo de imersão, caso das bandas de absorbância em $610 \mathrm{~cm}^{-1}, 1120 \mathrm{~cm}^{-1}, 1400 \mathrm{~cm}^{-1}, 1500 \mathrm{~cm}^{-1}, 1650 \mathrm{~cm}^{-1}, 2650 \mathrm{~cm}^{-1}, 2850 \mathrm{~cm}^{-1}$, $2939 \mathrm{~cm}^{-1}, 3400 \mathrm{~cm}^{-1}$. As relações inversamente proporcionais corresponderam às bandas de valência em $815 \mathrm{~cm}^{-1}, 850 \mathrm{~cm}^{-1}, 1360 \mathrm{~cm}^{-1}, 2325 \mathrm{~cm}^{-1}$, e as bandas de absorção que não apresentaram relação direta, caso das bandas em 962, $1980 \mathrm{~cm}^{-1}, 2120 \mathrm{~cm}^{-1}, 2325 \mathrm{~cm}^{-1}$. Para o elemento cério, tanto para a forma química óxido e nitrato, são relatados modos vibracionais em $610 \mathrm{~cm}^{-1} \mathrm{e} 2850 \mathrm{~cm}^{-1}$ (TSONCHEVA, 2013). Estes modos vibracionais foram quantizados partindo dos espectros das superfícies dos tratamentos T1, T10 e T20, e observou-se que a intensidade dos mesmos aumenta em função do tempo de imersão.

Picos em $1120 \mathrm{~cm}^{-1}$ e $1.478 \mathrm{~cm}^{-1}$ correspondem ao modo vibracional do carbonato de zinco $\left(\mathrm{ZnCO}_{3}\right)$, cuja intensidade aumenta com o tempo de tratamento de T1 a T20. Isto mostra que maiores tempo de imersão levam à maior quantidade de produtos de corrosão (carbonato de zinco). A presença de picos mais intensos (indicativo de camadas mais espessas) observados em $1120 \mathrm{~cm}^{-1} \mathrm{e}$ $3500 \mathrm{~cm}^{-1}$ pode ser atribuída à presença de $\mathrm{Zn}(\mathrm{OH})_{2}$, de $\mathrm{Zn}_{5}\left(\mathrm{CO}_{3}\right)_{2}(\mathrm{OH})_{6}$ ou de $\mathrm{ZnCO}_{3}$ o que pode ser explicado pela reação de íons carbonatos em solução (absorção de $\mathrm{CO}_{2}$ ) e os íons $\mathrm{Zn}^{2+}$ a partir da dissolução do substrato (KEDDAM, 1992).

A presença dos picos localizados em $815 \mathrm{~cm}^{-1}\left(-\mathrm{CH}_{3}\right), 992 \mathrm{~cm}^{-1}\left(\mathrm{CH}_{2}^{-}\right)$, $1120 \mathrm{~cm}^{-1}\left(-\mathrm{CH}_{3}\right), 1980 \mathrm{~cm}^{-1}$ e $2120 \mathrm{~cm}^{-1}(\mathrm{H}-\mathrm{C}=\mathrm{O})$ indicam a presença de partes da molécula do precursor polimérico, ou de outra estrutura orgânica, originária do mesmo, as quais devem ter sido incorporadas e / ou adsorvidas na superfície (SOCRATES, 1994).

Os picos em $1100 \mathrm{~cm}^{-1}$ e $1220 \mathrm{~cm}^{-1}$ estão relacionados à ligação entre carbono e oxigênio (C-O) e à ligação entre carbono, oxigênio e hidrogênio (C-O$\mathrm{H}$ ), cujo pico corresponde ao estiramento das ligações do grupo COO- Picos presentes em $1100 \mathrm{~cm}^{-1}, 1220 \mathrm{~cm}^{-1}$ e $1362 \mathrm{~cm}^{-1}$ confirmam a presença do grupo carbonila (AUINAT, 2005; WANG, 2008) e são definidas como bandas de absorção fracas. A presença de ácido carboxílico foi observada no filme nos resultados de FTIR. A presença destes foi investigada também por 
Espectroscopia fotoeletrônica de raios $X$ (XPS), sendo os resultados sequencialmente apresentados.

Os resultados de FTIR também permitem observar a ligação entre o grupo carboxil e o substrato metálico. As ligações entre o grupo carboxil e o substrato metálico podem ocorrer de diferentes maneiras e são nomeadas segundo o número, forma espacial e número de ligantes com o metal. Segundo Kennegan (JOHNSON, 1981, CLEGG, 1986, BISWICK, 2009), as ligações podem ser monodentadas, bidentadas e ponte, Figura 23. As ligações entre grupos carboxílicos e substratos metálicos são estudadas como fonte de obtenção de polímeros e formação de rede tridimensional polimérica (CAPILLA, 1979, MEHROTRA, 1983).<smiles>[M]OC([R])=O</smiles>

(A)<smiles>[M]OC([R])O[M]</smiles>

(B)<smiles>[R]C1=[M]O1</smiles>

(C)

Figura 23: Representações estruturais para tipos de ligações entre ácidos carboxílicos e metais. A) ligação monodentada; B) ligação bidentada e C) ligação ponte.

Os resultados de FTIR na forma de bandas de absorbância localizadas em $990 \mathrm{~cm}^{-1}, 1643 \mathrm{~cm}^{-1}, 2212 \mathrm{~cm}^{-1} \mathrm{e} 2820 \mathrm{~cm}^{-1}$, relacionadas ao grupo carboxil, foram ajustados e quantificados, o que permitiu relatá-los como diretamente proporcionais ao tempo de imersão. No entanto, bandas de absorbância localizadas em $1366 \mathrm{~cm}^{-1}, 1500 \mathrm{~cm}^{-1} \mathrm{e} 1643 \mathrm{~cm}^{-1}$, reportados como pertencentes ao grupo carboxil, ligado como ligante bidentado, são inversamente proporcionais ao tempo de imersão.

De acordo com os resultados observados, tempos maiores de tratamento levam a formação de camada orgânica mais espessa e com menor número de ligações com o substrato (zinco) e, portanto, de fácil remoção (maior número de defeitos). A identificação de cério e composto orgânico (grupos metil, carboxil etc.) 
responde à questão que surgiu durante a elaboração do trabalho sobre a possível incorporação de cério e formação de composto orgânico.

As análises por Espectroscopia Fotoeletrônica de Raios X (XPS) permitiram a obtenção de resultados qualitativos e quantitativos quanto aos elementos presentes na camada formada pelos tratamentos testados. Os espectros XPS gerais, para as superfícies com os tratamentos T1, T10 e T20 são mostrados na Figura 24.

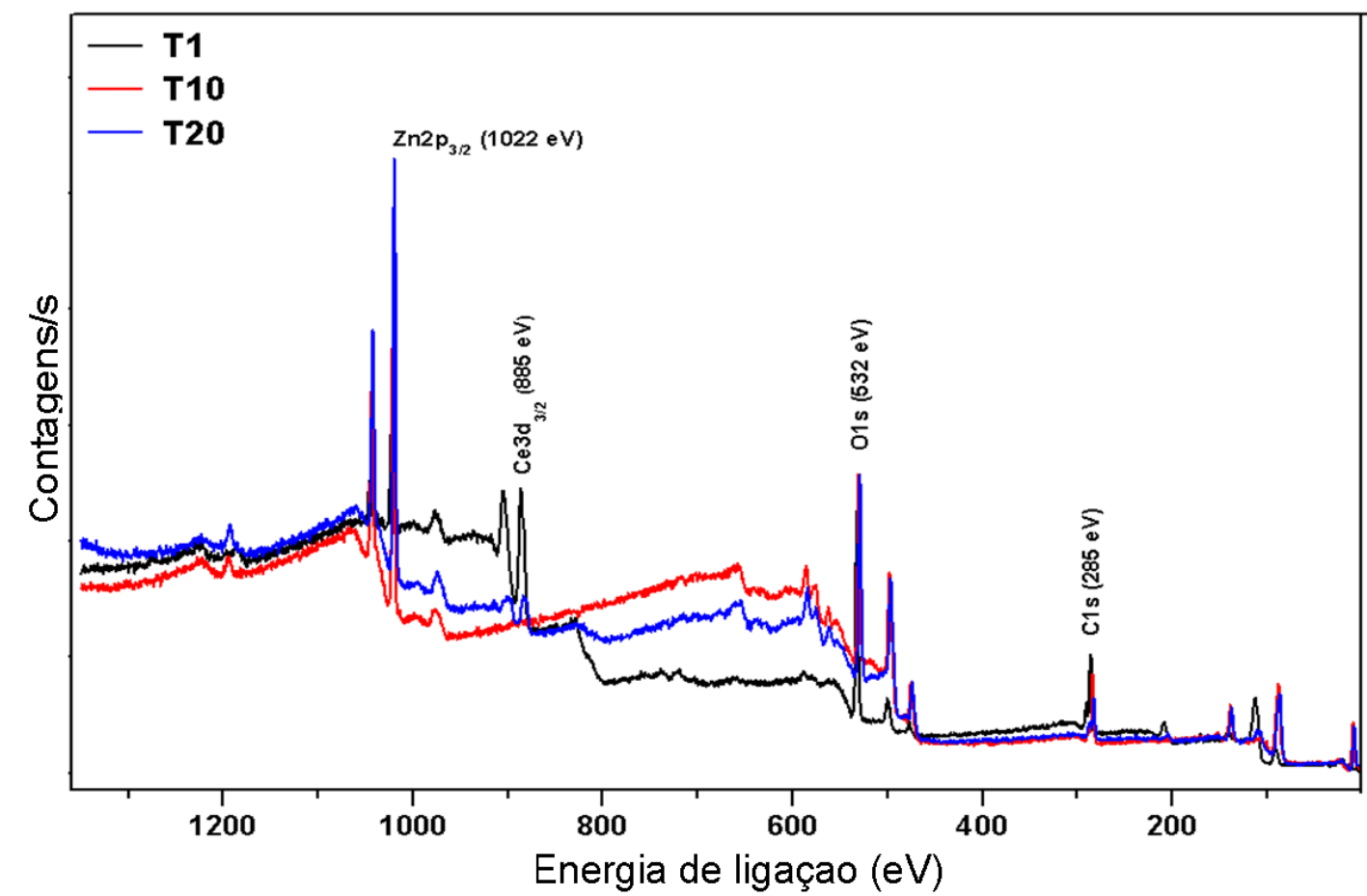

Figura 24: Espectros gerais obtidos por Espectroscopia Fotoeletrônica de Raios $X$ (XPS) das camadas formadas em superfície de aço eletrozincado, pelos tratamentos T1, T10 e T20.

O espectro geral de XPS permite observar a presença dos elementos: carbono (C1s, $285 \mathrm{eV})$, oxigênio $(\mathrm{O} 1 \mathrm{~s}, 532 \mathrm{eV})$, zinco $\left(\mathrm{Zn}_{2} \mathrm{p}_{3 / 2}, 1022 \mathrm{eV}\right)$ e cério $\left(\mathrm{Ce} 3 \mathrm{~d}_{5 / 2}, 885 \mathrm{eV}\right)$. A obtenção deste tipo de espectro permitiu a aquisição posterior de espectros de melhor resolução (maior número de varreduras) para cada uma das espécies identificadas. Análises das superfícies com maior número de varreduras, padronizados para todo 0 trabalho, mostraram diferentes concentrações. Os valores das concentrações, picos, energias de ligação e fator de ajuste (FWHM) são apresentados na Tabela 5. 
Tabela 5: Concentrações atômicas, picos, energias de ligação e fatores de ajuste obtidos por espectroscopia fotoeletrônica de raios X (XPS) para as tratamentos T1, T10 e T20.

\begin{tabular}{|c|c|c|c|c|c|}
\hline & \multicolumn{3}{|c|}{ AMOSTRAS } \\
\hline & & & T1 & T10 & T20 \\
\hline PICOS & E.L (eV) & F.W.H.M & \multicolumn{3}{|c|}{$\begin{array}{c}\text { at } \% \\
\text { Porcentagem em massa }\end{array}$} \\
\hline C1s & 285 & 1,80 & 39,9 & 34,6 & 24,1 \\
\hline 01s & 532 & 2,20 & 49,5 & 43 & 52,9 \\
\hline Zn2p3 & 1022 & 2,20 & 3,97 & 15,3 & 20,1 \\
\hline Ce3d & 886 & 2,10 & 6,65 & 7,1 & 2,9 \\
\hline
\end{tabular}

Os resultados mostraram que as superfícies apresentam altos teores de carbono e que estes tendem a diminuir com o tempo de imersão (T1 a T20). Causas prováveis para a diminuição da quantidade superficial de carbono seriam: a diminuição da espessura em algumas regiões, análise em região de defeitos e presença de contaminantes, especificamente, carbonos adventícios com ligantes C-C/C-H (ESTRADE-SZWARCKOPF, 2004). Sabe-se que o maior tempo de imersão na solução de tratamento provoca a formação de camadas mais espessas e mais defeituosas, condizente com o que foi observado nas imagens tridimensionais (microscopia ótica) e micrografias (FEG) apresentadas nas Figuras 17,18 e 19 .

A possibilidade de análise em região de defeito foi descartada, pois o procedimento de análise adotado, varreduras em três regiões diferentes, com desvio mínimo de $10 \%$ e a apresentação dos valores médios, impede a propagação de erros. Isto leva a crer que os valores das concentrações de carbono tendem a diminuir devido à presença de contaminantes, fracamente adsorvidos na superfície. A hipótese de que os carbonos façam parte de composto orgânico e que efetivamente estejam ligados ao substrato $(\mathrm{ZnO})$ dirigiu o trabalho para a realização de análises mais precisas, conhecidas como perfil de profundidade, onde espécies fracamente adsorvidas são removidas por íons argônio, e novos espectros são obtidos ao longo da espessura da camada. 
A Figura 25 mostra o perfil de profundidade obtido em função do tempo de incidência de íons argônio (sputtering) representados pelos espectros dos elementos componentes do filme superficial formado pelo tratamento T1.

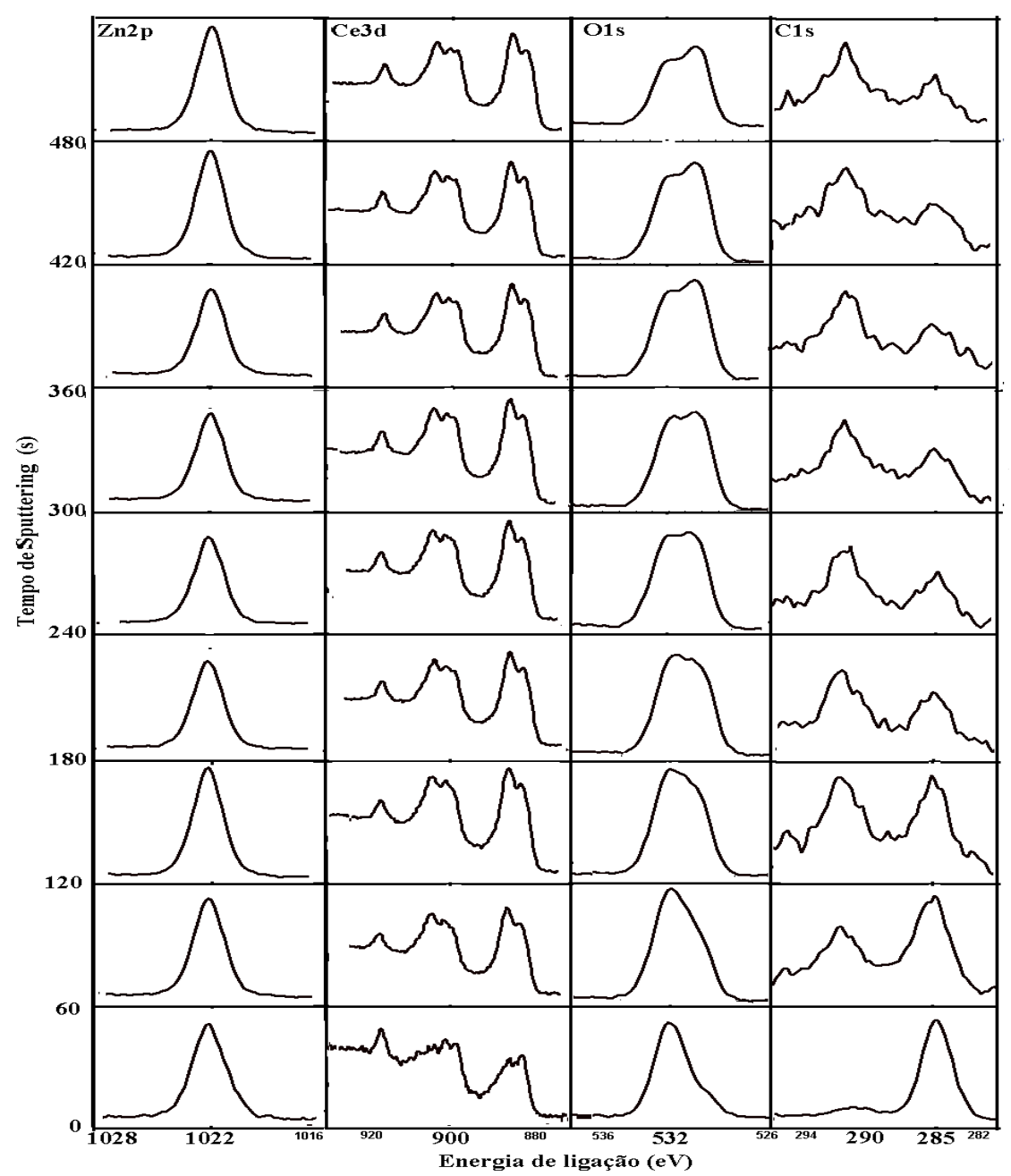

Figura 25: Espectros de XPS para os elementos C 1s, O 1s, Ce 3d e Zn 2p da superfície do aço eletrozincado após tratamento por 1 minuto (T1).

O perfil de profundidade, indicado em função do tempo de sputtering, mostra uma fina camada de material carbonáceo na superfície, carbono alifático acidental/contaminante. Este filme de carbono pode ser formado até mesmo em tempos reduzidos de exposição ao ar (BRIGGS, 1992, CASTLE, 2002). O pico presente em 285,0 eV foi relacionado às ligações C-C e C-H para correção de carga, associado a compostos orgânicos, apoiando a hipótese de formação de 
camada orgânica em consequência do tratamento de imersão. Quatro componentes, C-C/C-H (BE = 285,0 eV), C-O/C-OH, (BE =286,3 - 286,4 eV), $\mathrm{C}=\mathrm{O}(\mathrm{BE}=287,8-287,9 \mathrm{eV})$ e $\mathrm{O}-\mathrm{C}=\mathrm{O}(\mathrm{BE}=288,8-289,5 \mathrm{eV})$, foram usados nos ajustes do C1s (LEADLEY, 1997).

Os resultados de XPS permitem observar que para a amostra com tratamento T1 há uma mudança significativa nos formatos dos espectros com a profundidade. A presença de carbono, representada por dois picos e a existência e intensificação do pico em $290 \mathrm{eV}$, mesmo depois de tempo prolongado "sputtering" é uma evidência de que a camada analisada possui carbonos referentes a compostos orgânicos fortemente ligados ao substrato metálico. Os espectros mostram que a camada possui carbono, cério, oxigênio e zinco em todos os níveis de profundidade analisados, evidência de uma camada mista orgânica / inorgânica.

A variação dos formatos dos espectros é um indicativo de mudança de estado químico, associado aos valores dos números de oxidação. O deslocamento do pico do oxigênio para menores valores de energia de ligação mostra que, quanto mais internamente na camada, maior é a contribuição deste na forma de óxido.

O deslocamento do pico de zinco para regiões de menor energia de ligação indica uma contribuição cada vez maior do zinco metálico, o que se deve a aquisição dos espectros em níveis de profundidades cada vez maiores. A maior quantidade de zinco metálico indica que mais próximo ao substrato foi feita a aquisição de espectro. A Figura 26 mostra o perfil de profundidade obtido em função do tempo de incidência de íons argônio (sputtering) representados pelos espectros dos elementos componentes do filme superficial formado para o tratamento $\mathrm{T} 10$. 


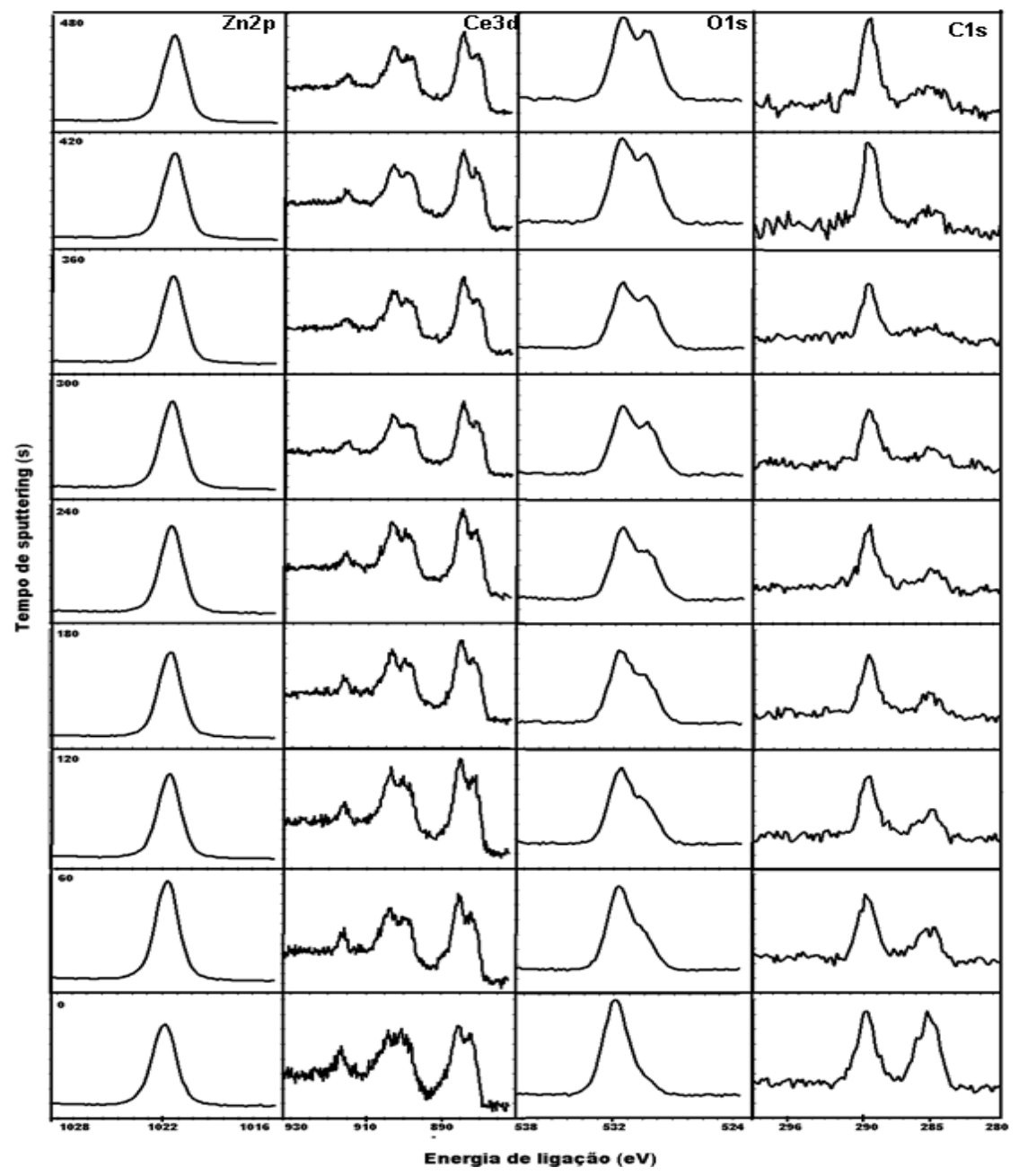

Figura 26: Espectros de XPS para os elementos C 1s, O 1s, Ce 3d e Zn 2p na superfície do aço eletrozincado após tratamento por 10 minutos (T10).

A aquisição dos espectros em função da profundidade permitiu ajustes matemáticos para os picos de cada elemento e os resultados para o elemento carbono da amostra com tratamento T10 são mostrados na Tabela 6 .

Tabela 6: Concentrações atômicas e fatores de ajuste para elemento $\mathrm{C} 1 \mathrm{~s}$, obtidas por espectroscopia fotoeletrônica de raios X (XPS) em função do tempo de sputtering (s), amostra com tratamento T10.

\begin{tabular}{lccccc}
\hline $\begin{array}{l}\text { Tempo etch (s) } \\
\text { C1s (fitting) } \\
\text { TRAT. T10 }\end{array}$ & 0 & 60 & 240 & 300 & 480 \\
C-C/C-H & \multicolumn{5}{c}{$\begin{array}{c}\text { at\% } \\
\text { porcentagem em massa }\end{array}$} \\
\cline { 2 - 6 } C-O/C-OH & 87,9 & 47,0 & 22,2 & 20,0 & 20,5 \\
C=O & 3,5 & 6,7 & 7,3 & 4,6 & 2,4 \\
O-C=O & 1,0 & 10,3 & 10,0 & 10,4 & 7,6 \\
\hline & 7,6 & 36,0 & 61,5 & 65,0 & 69,5 \\
\hline
\end{tabular}


Os ajustes para o pico do carbono referente ao tratamento T10 mostraram que carbonos funcionalizados como $\mathrm{C}-\mathrm{O}, \mathrm{C}-\mathrm{OH}, \mathrm{C}=\mathrm{O}$ e $\mathrm{O}-\mathrm{C}=\mathrm{O}$ representam a maior parcela da concentração relativa da camada formada. O grupo carboxil associado às ligações com o substrato metálico, ligante bidentado, aumenta com o tempo de sputtering, comprovando a presença deste grupo mais internamente na camada de conversão, ou seja, ligado ao revestimento de zinco óxido / hidróxido / metálico.

Para os ajustes do elemento zinco $\mathrm{Zn} 2 \mathrm{p}_{3 / 2}$, relativo ao óxido de zinco, o pico do óxido pode geralmente ser atribuído com base em FWHM. Isto se deve ao fato que, mesmo livre de divisão de multipleto e outros efeitos complicadores, como a sobreposição com o pico de energia de ligação da forma metálica, o pico relativo ao óxido de zinco tem um valor em elétron Volt (eV) maior, comparativamente ao zinco metálico, possibilidade de ajuste para óxido, hidróxido e metálico proposto por Biesinger (BIESINGER, 2011).

A sobreposição espectral faz com que sistemas mistos, contendo óxido/hidróxido de zinco e sua forma metálica, sejam de difícil quantificação. No entanto, nos casos em que o zinco metálico está em contato elétrico com um substrato condutor (aço), é possível a diferenciação em relação ao substrato (BAKER, 2009). O sistema de neutralização de cargas desloca o pico de óxido para uma energia de ligação inferior, o que permite uma separação entre picos ajustados (zinco metálico e o óxido), evidenciado por áreas diferentes que podem ser quantificadas, Tabela 7 .

Tabela 7: Concentrações atômicas e fatores de ajuste para Zn2p, obtidas por espectroscopia fotoeletrônica de raios X (XPS) em função do tempo de sputtering (s), amostra com tratamento T10.

\begin{tabular}{lccccc}
\hline Tempo etch (s) & 0 & 60 & 240 & 300 & 480 \\
Zn2p (fitting) & \multicolumn{5}{c}{$\begin{array}{c}\text { at\% } \\
\text { TRAT. T10 }\end{array}$} \\
\cline { 2 - 6 } & \multicolumn{7}{c}{ porcentagem em massa } \\
Zn (Metal) & 8,0 & 3,5 & 0,93 & 8,9 & 32,1 \\
ZnO & 87,3 & 94,2 & 91,0 & 88,9 & 66,6 \\
Zn(OH) & 4,7 & 2,3 & 8,1 & 2,2 & 1,3 \\
\hline
\end{tabular}


Os resultados do ajuste para o pico de zinco mostram a eficiência do sputtering usado. Isto é possível ao observar o sinal de zinco metálico, que possui o valor mais alto em 480 segundos, maior quantidade de material removido e mais internamente na camada formada. Os espectros de XPS não mostraram a presença de $\mathrm{ZnCO}_{3}$ que foi evidenciado por FTIR.

Embora as concentrações de óxido de zinco sofram alterações com a evolução do tempo de sputtering os valores são superiores quando comparadas às outras formas químicas presentes, metais e hidróxido. A maior concentração de zinco na forma de óxido de zinco permite concluir que 10 minutos de imersão na solução contendo cério é suficiente para o ataque e dissolução do zinco.

O hidróxido de zinco é um produto de corrosão, que ocorre em estágio inicial no processo cinético da corrosão deste metal. Os ajustes para o elemento zinco, dos resultados obtidos por XPS, mostram que o hidróxido de zinco é remanescente do processo de corrosão que levou a formação da camada orgânica contendo óxido de zinco.

O oxigênio, quando ligado a componentes orgânicos, pode mostrar uma variação significativa nas energias de ligação e apresentar valores que podem ir de 530,9 eV até 533,8 eV. Entre as espécies mais comuns de orgânicos, estão os ácidos orgânicos ou carboxílicos que, são encontradas em intervalos de energia de ligação menores de 532,0 eV a 533,7 eV (XIE, 1990).

A dificuldade de se determinar os estados químicos do oxigênio (óxido, hidróxido e água de hidratação) reside no fato de sua concentração estar associada a outras espécies residuais, como é o caso do carbono adventício (CC/C-H), forma contaminante, ou de carbono fracamente ligado (BRIGGS, 1992), especificamente na forma de carbonatos (BIESINGER, 2011).

Para obter uma relação exata das formas químicas do oxigênio na camada ou filme formado, os valores atribuídos aos carbonos residuais foram subtraídos e a diferenciação (estados químicos) e a concentração atômica destes estados em função do tempo de sputtering são mostradas na Tabela 8. 
Tabela 8: Concentrações atômicas e fatores de ajuste para O1s, obtidas por espectroscopia fotoeletrônica de raios X (XPS) em função do tempo de sputtering (s), amostra com tratamento T10.

\begin{tabular}{lccccc}
\hline $\begin{array}{l}\text { Tempo etch (s) } \\
\text { O1s (fitting) }\end{array}$ & 0 & 60 & 240 & 300 & 480 \\
TRAT. T10 & \multicolumn{5}{c}{$\begin{array}{c}\text { at\% } \\
\text { porcentagem em massa }\end{array}$} \\
$\mathrm{O}^{2-}$ & 11,7 & 18,4 & 65,3 & 70,7 & 84,3 \\
$\mathrm{OH}^{-}$ & 74,9 & 63,2 & 34,7 & 29,3 & 15,7 \\
$\mathrm{H}_{2} \mathrm{O}$ & 13,4 & 18,4 & 0,0 & 0,0 & 0,0 \\
\hline
\end{tabular}

Os resultados para o ajuste do pico $O$ 1s mostraram uma concentração de oxigênio na forma de $\mathrm{H}_{2} \mathrm{O}$ até 60 segundos de sputtering, espécie adsorvida de fácil remoção. A adsorção de $\mathrm{H}_{2} \mathrm{O}$ pela camada orgânica é originária da adsorção e formação de complexos hidratados, caso do elemento cério. A permanência da amostra em câmara de alto vácuo e exposição a íons argônio, são fatores suficientes para total remoção de água de hidratação.

A forma química predominante observada para o oxigênio em tempos iniciais de sputtering é de hidróxido e com a evolução do tempo, próximo ou em direção ao revestimento de zinco, passa a ter a forma de óxidos. Os hidróxidos são quase que exclusivamente atribuídos a $\mathrm{Zn}(\mathrm{OH})_{2}$, uma vez que não foram observados hidróxidos para o elemento cério. Comparando-se os resultados das Tabelas 8 e 14, os maiores teores de oxigênio na forma $\mathrm{O}^{2-}$ nas partes mais externas da camada formada pelo tratamento T10_10 comparativamente ao tratamento T10 sugerem que o efeito da etapa de imersão em solução de peróxido de hidrogênio foi o de oxidação dos produtos de corrosão formados.

A investigação por XPS para as amostras obtidas pelo tratamento T1 mostrou a presença de cério em dois estados de oxidação química III e IV, com os ajustes mostrando diferentes formatos para estes estados finais de oxidação. As diferentes curvas de ajuste (satélites) para o cério são observadas na forma de

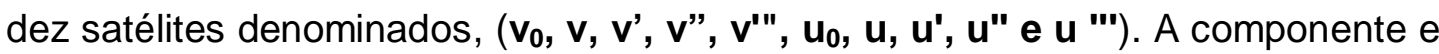
ou satélite (u'") é considerada como determinante para atestar a presença de $\mathrm{Ce}^{4+}$ (BÊCHE, 2008). As concentrações atômicas para os óxidos de cério para amostra com tratamento T10 são apresentadas na Tabela 9. 
Tabela 9: Concentrações atômicas e fatores de ajuste para Ce3d, obtidas por espectroscopia fotoeletrônica de raios X (XPS) em função do tempo de sputtering (s), amostra com tratamento T10.

\begin{tabular}{lccccc}
\hline $\begin{array}{l}\text { Tempo etch (s) } \\
\text { Ce3d (fitting) } \\
\text { TRAT. T10 }\end{array}$ & 0 & 60 & 240 & 300 & 480 \\
& \multicolumn{5}{c}{$\begin{array}{c}\text { at\% } \\
\text { porcentagem em massa }\end{array}$} \\
\cline { 2 - 6 } Ce III & 55,4 & 83,3 & 56,0 & 46,6 & 66,7 \\
Ce IV & 44,6 & 16,7 & 44,1 & 53,4 & 33,3 \\
\hline
\end{tabular}

Os picos referentes a cério em dois estados de oxidação aparecem em uma faixa de energia de ligação entre 880 e 920 eV. As análises com até 480 segundos de sputtering permitiram observar picos de menor intensidade em 919 $\mathrm{eV}$, indicando a presença de $\mathrm{Ce}^{4+}$ na forma de óxido $\mathrm{CeO}_{2}$. Estes resultados comprovam que a etapa de imersão em peróxido de hidrogênio possibilita a oxidação das espécies presentes na camada formada de cério trivalente a tetravalente, particularmente na parte mais interna (comparar Tabelas 9 e 16).

As presenças dos estados de oxidação $\mathrm{Ce}^{3+} \mathrm{e} \mathrm{Ce}^{4+}$, na forma de óxidos, resultam em melhora do desempenho de proteção contra a corrosão da camada de zinco (ARAMAKI, 2002). A presença de cério e sua continuidade com o tempo de desbaste, por íons argônio, sugerem que o cério esteja fortemente ligado a oxigênio de sítios do substrato de óxido de zinco, ou mesmo, ao filme orgânico depositado.

Pode-se afirmar, portanto, que houve a formação de um filme orgânico fino e que incorporado neste filme há $\mathrm{Ce}_{2} \mathrm{O}_{3}$ e $\mathrm{CeO}_{2}$. A quantidade destes óxidos varia com a profundidade, em direção ao revestimento de zinco. Diferentes tempos de imersão do aço eletrozincado em solução contendo $\mathrm{Ce}\left(\mathrm{NO}_{3}\right)_{3} \cdot 6 \mathrm{H}_{2} \mathrm{O}, \mathrm{NaNO}_{3}$, $\mathrm{Na}_{2} \mathrm{SO}_{4}$ e 2 butino-1,4-diol propoxilato, permitem a obtenção de camadas com diferentes morfologias, espessuras e constituição química.

As diferenças observadas nos formatos dos picos em função do tempo de imersão permitem afirmar que há uma mudança no estado de oxidação e mesmo de estado químico (diferentes formas - metal, óxidos e hidróxidos) com o tempo 
de ataque/desbaste. A Figura 25 mostra o perfil de profundidade obtido em função do tempo de incidência de íons argônio (sputtering) representados pelos espectros dos elementos componentes do filme superficial formado para o tratamento T10.

Após 480 segundos de sputtering, foi possível observar a diminuição do pico em $285 \mathrm{eV}$ (C-C/C-H) e aumento do segundo pico próximo a $290 \mathrm{eV}$. A diminuição do primeiro pico e sua quase extinção em função do tempo de sputtering se deve à cominuição dos carbonos de fraca adsorção. $O$ aumento da intensidade do pico em $290 \mathrm{eV}$, característico de compostos orgânicos carboxilatos (JOHANSSON, 2003), mostra que quanto mais internamente na camada, maior a quantidade de espécies orgânicas fortemente ligadas (ligações covalentes) ao substrato.

Os resultados referentes ao elemento cério permitem observar que há uma diminuição do pico em $916 \mathrm{eV}$. No entanto, este ainda existe quando a análise se aproxima da interface zinco/óxido de zinco, atestando a presença de cério na forma de óxido com mais de um estado de oxidação e em toda a extensão da camada formada pelo tratamento T10. A Figura 27 mostra os diferentes formatos dos picos de carbono, oxigênio, zinco e cério para a amostra após tratamento por 20 minutos de imersão em solução com $\mathrm{Ce}\left(\mathrm{NO}_{3}\right)_{3} \cdot 6 \mathrm{H}_{2} \mathrm{O}, \mathrm{NaNO}_{3}, \mathrm{Na}_{2} \mathrm{SO}_{4}$ e 2 Butino-1,4-diol propoxilato (T20). 


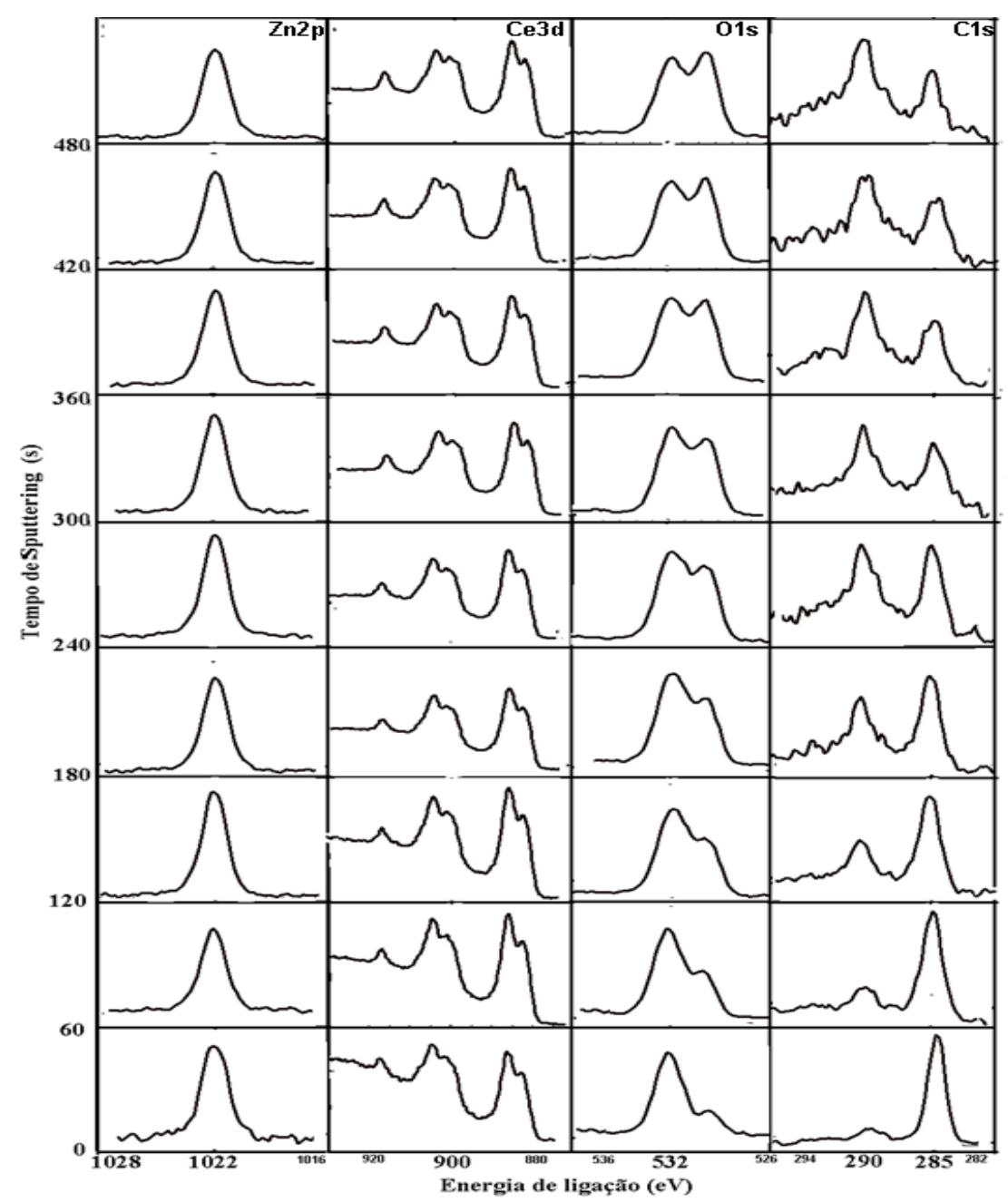

Figura 27: Espectro de XPS dos componentes, C 1s, O 1s, Ce 3d e Zn 2p para a superfície de aço eletrozincado e passivado por imersão por 20 minutos (T20).

As diferenças observadas nos formatos dos picos em função do tempo de imersão permitem afirmar que há uma mudança de estados de oxidação e mesmo, de estado químico (diferentes formas - metal, óxidos e hidróxidos). A camada passiva formada para 20 minutos de imersão mostra semelhanças quanto a sua constituição às formadas por tratamentos em 1 e 10 minutos.

Também é possível observar que o tratamento de imersão leva à oxidação do substrato, o que é evidenciado, pela presença de óxidos em maior quantidade, sempre próximos à camada de zinco, o que se deve à oxidação da superfície pela solução ácida de tratamento $(\mathrm{pH}=4,2)$. Para todas as amostras fica evidente a formação, ou mesmo deslocamento, de um pico em direção a regiões de menor $\mathrm{eV}$ e, no caso oxigênio, este esta relacionado à presença de óxidos. 
Os valores ajustados das concentrações atômicas de zinco obtidas por XPS em função do tempo de sputtering permitiram constatar o aumento do sinal referente ao zinco na forma metálica com o aumento da profundidade, o que é esperado à medida que se aproxima do substrato.

A presença do zinco na forma de óxido mostra que tempos maiores de imersão no banho de tratamento promovem a oxidação do zinco, e na parte mais externa há a formação de hidróxido de zinco. Para $60 \mathrm{~s}$ de sputtering, a concentração de $\mathrm{Zn}(\mathrm{OH})_{2}$ é $0,5 \%$ para o tratamento $\mathrm{T} 1,2,3 \%$ para o tratamento T10 e 11,25\% para o T20. Maiores tempos na solução de conversão favorecem a formação de $\mathrm{ZnO}$ e $\mathrm{Zn}(\mathrm{OH})_{2}$, e isto se deve à agressividade da solução de tratamento do zinco devido a sua acidez ( $\mathrm{pH} 4,2)$ uma vez que há uma competição entre deposição e ataque do substrato.

As concentrações atômicas de carbono obtidas em função do tempo de sputtering para os tratamentos T1, T10 e T20 mostram que espécies fracamente ligadas e/ou mesmo adsorvidas ( $\mathrm{C}-\mathrm{C}$ e $\mathrm{C}-\mathrm{H}$ ) não são totalmente removidas após $480 \mathrm{~s}$ de remoção pelos íons argônio para todas as amostras testadas. Este tipo de ligação do carbono também pode ser associada a ligantes dentro de cadeias orgânicas, como carbonos secundários e terciários. Mesmo com redução de carbono contaminante em função do tempo de sputtering, próximo ao revestimento de zinco ainda é possível observar cerca de $20 \%$ do total de carbono, na amostra T20, como sendo de carbono contaminante. Para amostras tratadas por tempos menores ( $\mathrm{T} 1$ e T10), a concentração foi de cerca de $20 \%$ nos tempos mais elevados de sputtering, ou seja, mais internamente na camada formada. A camada formada pelo tratamento com duração de 20 minutos é mais espessa, no entanto, os resultados de XPS sugerem que, esta é mais fracamente ligada ao substrato metálico e, portanto, não confere proteção efetiva contra a corrosão.

\subsubsection{Observações gerais / respostas às perguntas propostas}

A hipótese de formação de filme orgânico (polimérico) e de ligação do polímero ao revestimento de zinco, proposta neste trabalho, foi confirmada e é 
fundamentada pela presença de unidades orgânicas que possuem grupo carboxílico - ácidos carboxílicos. Os resultados de XPS mostraram a presença de grupo carboxílico nas amostras tratadas por imersão na solução proposta, contendo 2-Butino-1,4-diol propoxilato, sulfato e nitrato de sódio e nitrato de cério hexa hidratado.

O tempo de 1 minuto de imersão mostrou-se insuficiente para a formação de quantidades consideráveis de orgânicos (carboxilas), e estas, quando formadas, ocorrem no interior da camada (entre 60 s e 480 s de sputtering). Fica evidente que a camada orgânica formada possui diferente constituição, sendo que os grupos carboxílicos presentes na mesma estão localizados mais internamente, enquanto outras espécies orgânicas, como carbonos contaminantes, são superficiais.

Para o tempo de tratamento de 10 minutos são observadas as mais altas concentrações de grupos carboxila e estas existem superficialmente e ligadas ao revestimento de zinco $(69 \%$ de carbono $\mathrm{C}-\mathrm{C}=\mathrm{O}$ após 480 segundos de sputtering). Este tempo de imersão mostrou-se o melhor, entre os tempos avaliados (1, 10 e 20 minutos) para o tratamento de proteção pela deposição de ácido carboxílico sobre o revestimento de zinco.

Os resultados permitiram também observar a presença de cério na forma de óxido em dois estados de oxidação (tri e tetravalente), desde a superfície externa até mais internamente, próximo do revestimento de zinco. Para o tratamento T1 observa-se cerca de $55 \%$ do cério é encontrado como cério trivalente na superfície, e 67\% próximo ao revestimento de zinco (após 480s de sputtering). Portanto, a quantidade de cério tetravalente foi de $45 \%$ na superfície e $33 \%$ na parte mais interna da camada orgânica formada.

Na superfície, os teores do íon cério trivalente são muito próximos para os três tratamentos testados, mas variam na camada orgânica. Segundo Aramaki (ARAMAKI, 2002), a oxidação do íon de cério trivalente para tetravalente é uma forma de conferir proteção contra a corrosão. Segundo o autor a mudança de estado de cério III para cério IV é uma forma protetiva, cuja similaridade com o mecanismo de autocura apresentado por tratamento de conversão de cromato 
sendo discutível. De qualquer maneira maiores quantidades de Ce III na camada confere proteção com sistemas oxidativo (corrosivos) promovendo-o a Ce IV na forma de óxido O óxido cérico (IV) é um produto de maior estabilidade (baixa solubilidade) que o óxido de cério III.

Maiores quantidades de $\mathrm{Ce}_{2} \mathrm{O}_{3}$ podem levar à formação de $\mathrm{CeO}_{2}$ na região de defeito, conferindo proteção por barreira devido à formação de óxido de baixa solubilidade. Desta forma, estoques de cério trivalente seriam maiores nas amostras obtidas pelos tratamentos T1 e T10, em comparação ao T20 (20 minutos de imersão). Dentre os tempos estudados, o melhor tempo, ou seja, o que resultou na obtenção de filme mais fortemente ligado (ligação covalente) ao revestimento de zinco e com maior quantidade de íons cério trivalente, foi o tempo de 10 minutos. As questões inicialmente propostas puderam ser respondidas e podendo-se concluir que o tratamento por imersão em solução contendo 2-Butino1,4-diol propoxilato, nitrato de cério hexa hidratado, sulfato de sódio e nitrato de sódio possibilita à formação de camada orgânica contendo cério incorporado na forma de óxido.

Com base nos resultados obtidos, foi possível propor modelos composicionais e estruturais para a camada orgânica formada, as quais são ilustradas nas Figuras 28 e 29. Foi possível também constatar que o tempo de imersão é de fundamental importância para os parâmetros estruturais e de composição desejados.

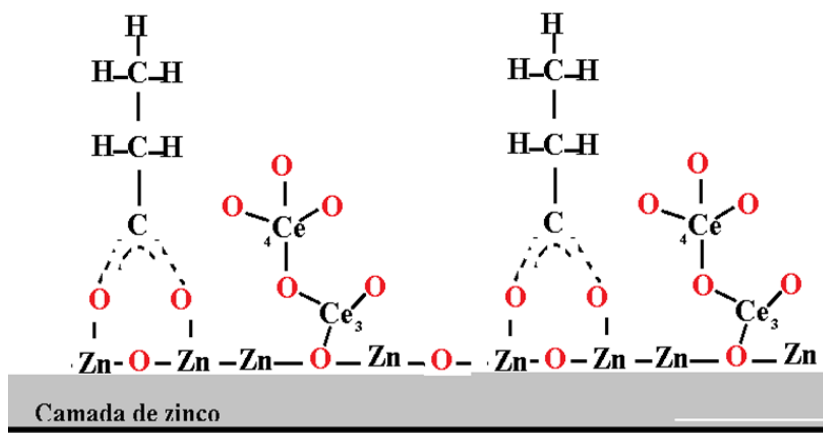

Figura 28: Representação das ligações de zinco do substrato com o grupo carboxil do ácido propanóico. 
A primeira hipótese admite ligação (covalente) entre o composto orgânico e o substrato de óxido de zinco, pelas extremidades dos grupos carboxílicos. A segunda hipótese proposta para a formação de camada polimérica é representada na Figura 28.

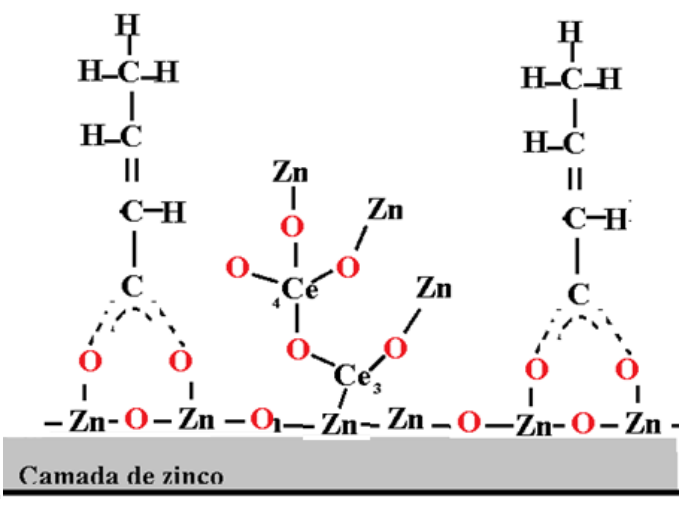

Figura 29: Representação das ligações de zinco do substrato com o grupo carboxil da substância ácido but-2enóico.

As duas hipóteses propostas acima são apoiadas pelos resultados de FTIR que mostram a presença de grupos orgânicos que permitem sugerir a formação e ligação de uma estrutura orgânica sobre o zinco. Análises qualitativas e quantitativas de espectroscopia fotoeletrônica de raios X (XPS) permitiram a obtenção de resultados que corroboram as duas hipóteses citadas. $O$ processamento dos dados obtidos por XPS possibilita a afirmação de quais das hipóteses (ligação do ácido propanóico ao substrato pelo grupo carboxil) é a mais provável, uma vez que as interações entre carbonos são representadas por bandas de fraca intensidade.

Outra questão importante é se a camada formada proporciona proteção contra corrosão do substrato de aço eletrozincado. Com o objetivo de responder a esta questão, a resistência à corrosão dos materiais após os tratamentos testados foi investigada por espectroscopia de impedância eletroquímica. Para efeito de comparação foi também estudado o comportamento eletroquímico (solução 0,1 mol. $L^{-1}$ de $\mathrm{NaCl}$ ), do substrato sem passivação (aço eletrozincado) e sua evolução com o tempo de imersão no eletrólito adotado assim como amostra de aço galvanizado tratada em solução de conversão à base de sais de cromo hexavalente (CCC). 
5.3.1.4. Resultados eletroquímicos (Ensaios de corrosão acelerada e Espectroscopia de Impedância Eletroquímica).

Os resultados obtidos por ensaios realizados em câmara de névoa salina são apresentados na Tabela 10, indicando os tempos observados para corrosão branca, início da corrosão vermelha e 10\% de corrosão vermelha.

Tabela 10: Tempos de exposição em névoa salina para as amostras de zinco sem e com tratamento: cromato e os tratamentos investigados em função do tempo de imersão em solução contendo cério por diferentes tempos de imersão, tratamentos, $\mathrm{T} 1, \mathrm{~T} 10$ e T20.

\begin{tabular}{lccc}
\hline & \multicolumn{3}{c}{ Tempo $(\mathrm{h})$ - Aparecimento de corrosão } \\
\cline { 2 - 4 } Tratamentos & $\begin{array}{c}\text { Corrosão } \\
\text { branca }\end{array}$ & $\begin{array}{c}\text { Corrosão } \\
\text { vermelha }\end{array}$ & $\begin{array}{c}\text { Corrosão } \\
\text { vermelha } \\
\mathbf{1 0 \%}\end{array}$ \\
\hline Zinco & 8 & 75 & 80 \\
Zinco + CCC & 96 & 240 & 250 \\
Zinco + T1 & 90 & 180 & 206 \\
Zinco + T10 & 120 & 336 & 400 \\
Zinco + T20 & 120 & 206 & 230 \\
\hline
\end{tabular}

Dos revestimentos propostos o tratamento com 1 minuto de imersão (T1) mostrou valores muito próximos aos valores apresentados para zinco tratado em solução de cromato, apontando para a potencialidade dos tratamentos propostos.

Para tratamentos com 10 minutos (T10) os valores mostraram que resiste mais tempo para o aparecimento dos produtos de corrosão e, mesmo quando estes produtos estão presentes, resiste por quase o dobro do tempo apresentado pelo tratamento de referência (cromatos) para que 10\% de sua área exposta apresentem corrosão do substrato (corrosão vermelha).

Mesmo o tratamento T20 apresentando valor para o tempo de corrosão branca superior ao valor apresentado pelo tratamento de referência (cromato), este tem proteção a corrosão inferior, de pontos iniciais até 10\% de corrosão vermelha. A presença de filme orgânico dificulta a formação de produtos iniciais de corrosão, no entanto, após a formação destes produtos o processo de corrosão é acelerado, provavelmente pelo grande número de defeitos superficiais 
formados nestas amostras. Os defeitos possibilitam a penetração de maior quantidade de eletrólito e ataque mais efetivo do mesmo ao revestimento de zinco até a base do aço.

Os resultados obtidos por Espectroscopia de Impedância Eletroquímica do aço eletrozincado sem tratamento de passivação, ou tratado por imersão em solução de cromato, ou pelos vários tratamentos propostos neste estudo em solução de nitrato de cério hexahidratado com 2 butino-1,4 diol propoxilato, nitrato de sódio e sulfato de sódio são apresentados nas Figuras 30 e 31, pelos diagramas de Nyquist para tempos diferentes (1, 3, 5 e 7 dias), em contato com solução de cloreto de sódio 0,1 mol.:-1 ${ }^{-1}$.
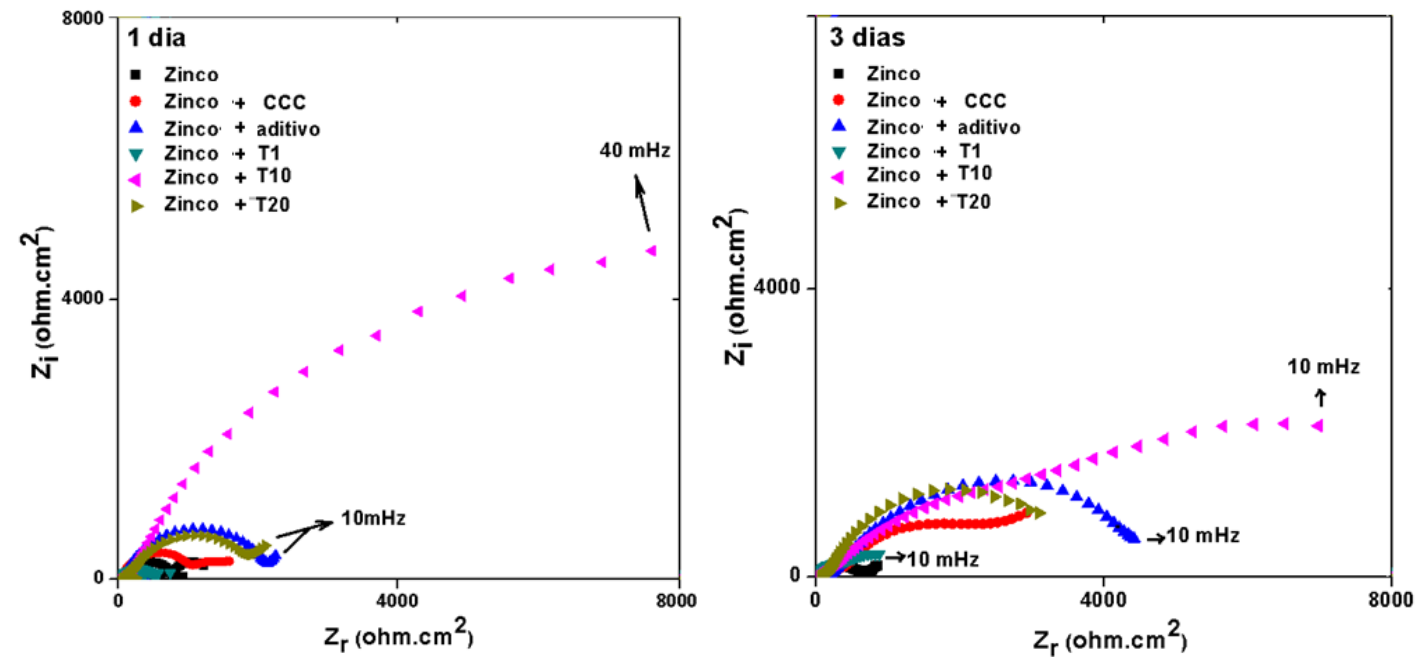

Figura 30: Diagramas de Nyquist para 1, 3 dias de imersão em $0,1 \mathrm{~mol}^{-1}$ de $\mathrm{NaCl}$, amostras de zinco, zinco + cromo VI, zinco + 2 butino-1,4 diol propoxilato, zinco + tratamento T1, zinco + tratamento T10 e zinco + tratamento T20. 

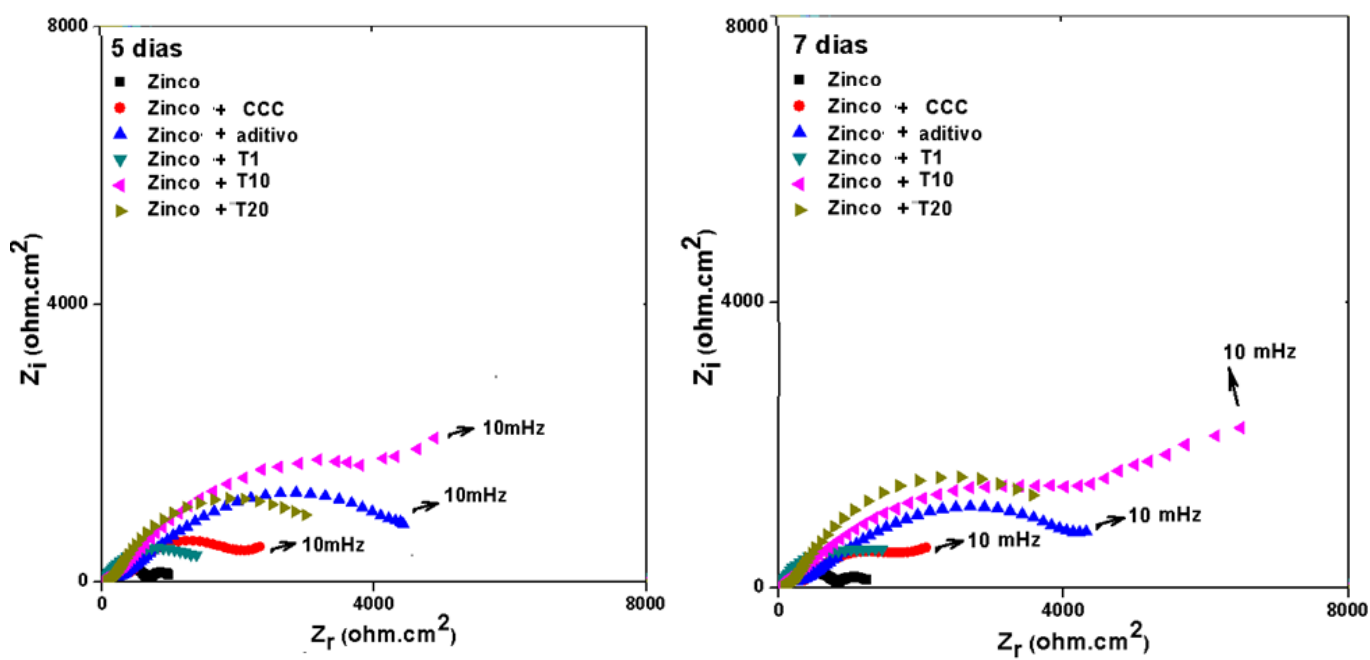

Figura 31: Diagramas de Nyquist para 5 e 7 dias de imersão em $0,1 \mathrm{~mol}^{-1} \mathrm{~L}^{-1}$ de $\mathrm{NaCl}$, amostras de zinco (substrato), zinco + cromo VI, zinco +2 butino-1,4 diol propoxilato, zinco +tratamento $\mathrm{T} 1$, zinco +tratamento $\mathrm{T} 10$ e zinco +tratamento T20.

A evolução de impedância eletroquímica, mostrada como diagramas de Nyquist para o aço eletrozincado com camada de conversão à base de íons de cromo hexavalente, permite observar aumento de impedância entre 1 e 3 dias de imersão, e pequena diminuição entre 3 e 7 dias. $O$ aumento de impedância pode ser explicado pela precipitação de produtos de corrosão insolúveis na forma de cromatos na superfície do aço eletrozincado em função do tempo de exposição, entre 1 e 3 dias, como é esperado de revestimentos com propriedade de autocura.

O consumo do cromo com a precipitação de produtos sobre superfície exposta ao meio corrosivo é responsável pela diminuição da impedância entre 3 e 7 dias. A literatura relaciona a efetividade da camada de óxido de cromo na proteção contra corrosão dos aços zincados (self healing) com a espessura da camada, sua continuidade e aderência à superfície metálica (ZHAO, 2001). A camada obtida no presente estudo foi de espessura nanométrica.

Os resultados de impedância eletroquímica, diagramas de Nyquist para o aço eletrozincado, ativação com tratamento de conversão obtido em solução de nitrato de cério hexahidratado com 2 butino-1,4 diol propoxilato, nitrato de sódio e sulfato de sódio por 1 minuto, T1, permite observar que a impedância aumenta 
em função do tempo de imersão, possivelmente pela formação e incorporação de produtos de corrosão do zinco e do cério (óxidos e hidróxidos), de baixa solubilidade, na camada orgânica formada. Estes dificultam a permeabilidade do eletrólito e aumentam a resistência à corrosão por camada barreira.

Os resultados de impedância eletroquímica em função do tempo (dias) em solução 0,1 mol. $\mathrm{L}^{-1}$ de $\mathrm{NaCl}$ para o aço eletrozincado, após tratamento de imersão de 10 minutos na solução contendo cério, permitem observar que, provavelmente devido ao ataque da camada de zinco eletrodepositada, durante o tratamento de passivação por imersão em meio ácido, houve formação de produtos de corrosão do zinco e, consequentemente, de defeitos superficiais evidenciados na camada formada pelo tratamento de passivação.

A porosidade para este tipo de superfície muito provavelmente se deve à formação de hidróxidos, relatados como produtos de corrosão iniciais para zinco, o que explica a contribuição de processos controlados por difusão indicados no primeiro dia. Durante o ensaio de corrosão por imersão, o eletrólito penetra pela camada formada e entra em contato com o metal ao atingir o substrato. Isto se dá mais facilmente pelos defeitos na camada, causando o ataque corrosivo do zinco metálico, o que explica a diminuição da impedância entre 1 e 3 dias de imersão. Em consequência do ataque corrosivo, ocorre a formação de produtos de baixa solubilidade, particularmente hidróxidos de zinco e de cério. A formação destes produtos, por sua vez, leva ao preenchimento de defeitos da camada, aumentando temporariamente a impedância e causando posterior estabilização destes valores para períodos de imersão superiores a três dias.

Os resultados eletroquímicos comparativos, Figuras 29 e 30, permitem evidenciar que tratamentos contendo compostos de cério, propostos neste trabalho, foram superiores aos demais tratamentos. Entre os tratamentos em solução com sais de cério, os resultados mostraram que os maiores valores de impedância correspondem às amostras tratadas por 10 minutos. Este tempo de tratamento foi o escolhido, então, para dar continuidade ao estudo do efeito de outras etapas de tratamentos. Na Figura 32 são apresentados os resultados de EIE, diagramas de Nyquist e Bode (ângulo de fase), amostra T10 entre 1 e 7 dias de evolução em 0,1 mol. $\mathrm{L}^{-1}$ de $\mathrm{NaCl}$. 

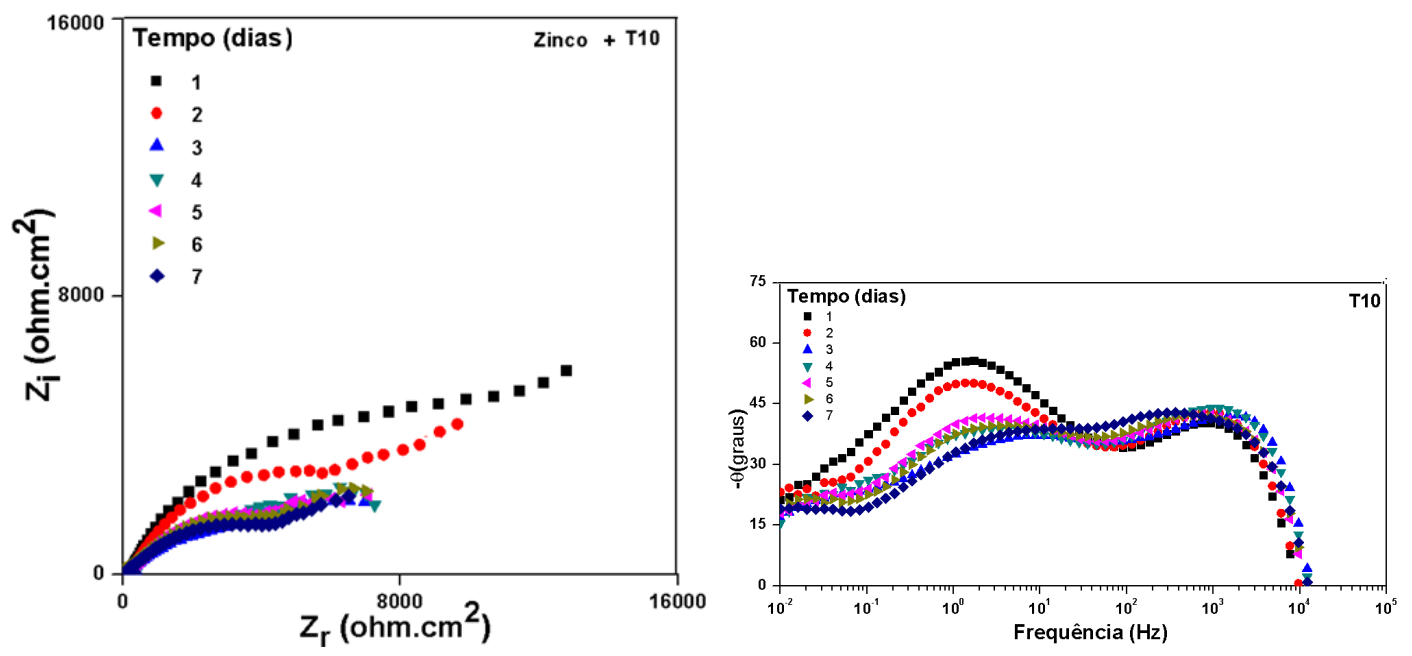

Figura 32: Diagramas de Nyquist e Bode (ângulo de fase) obtidos entre 1 e 7 dias de imersão em solução de $\mathrm{NaCl}$ 0,1M para amostra com tratamento T10.

Os diagramas de Bode (ângulo de fase) sugerem a presença de três constantes de tempo com indicação de processos difusionais a baixas frequências, desde o segundo dia de imersão. Provavelmente devido ao ataque da camada de zinco eletrodepositada, durante o tratamento de passivação por imersão em meio ácido levando à formação de produtos de corrosão do zinco e, consequentemente, de defeitos superficiais evidenciados na camada formada pelo tratamento testado (HAMLAOUI, 2008). A porosidade para este tipo de superfície muito provavelmente se deve à formação de hidróxidos, relatados como produtos de corrosão iniciais para zinco, o que explica a contribuição de processos controlados por difusão a baixas frequências.

O comportamento eletroquímico pode ser melhor observado no gráfico Nyquist para a amostra T10 com tempo de imersão de 3 a 7 dias. Durante 0 ensaio de corrosão por imersão, o eletrólito entra em contato com o substrato metálico, mais facilmente pelos defeitos na camada e, causando o ataque corrosivo do zinco metálico, o que explica a diminuição da impedância entre 1 e 3 dias de imersão. Em consequência ao ataque pelo processo corrosivo, ocorre a formação de produtos de baixa solubilidade, particularmente hidróxidos de zinco e de cério. A formação destes produtos, por sua vez, levam ao preenchimento de defeitos, aumentando temporariamente a impedância e posterior estabilização destes valores para períodos de imersão superiores a três dias. 
A amostra T10 apresentou os melhores resultados de impedância eletroquímica, comparativamente aos outros tratamentos testados. Os resultados eletroquímicos foram ajustados para a amostra T10 para a obtenção de circuitos elétricos equivalentes, para o primeiro dia e do segundo ao sétimo dia de imersão em solução 0,1 mol. $\mathrm{L}^{-1}$, respectivamente circuitos Figura $33(\mathrm{~A})$ e $(B)$.

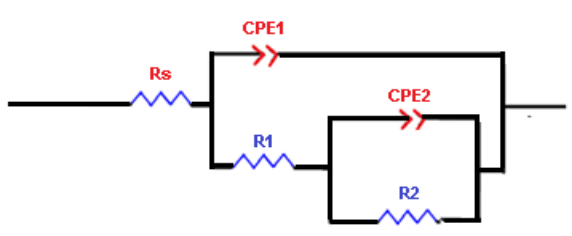

(A)

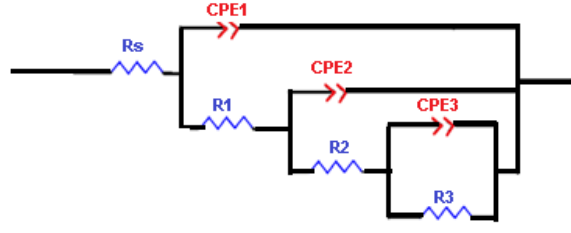

(B)

Figura 33. Circuitos elétricos equivalentes (CEE) utilizados nos ajustes dos dados de espectroscopia de impedância eletroquímica: (A) arranjo com duas constantes de tempo em cascata para o primeiro dia, (B) arranjo com três constantes de tempo adotado do segundo ao sétimo dia de imersão em $\mathrm{NaCl} 0,1 \mathrm{~mol} . \mathrm{L}^{-1}$.

Os dados experimentais de impedância foram ajustados para um circuito elétrico equivalente composto por dois circuitos capacitivos vistos nos diagramas de Nyquist, em altas e médias frequências e outra a baixas frequências, conforme mostrado na Figura 32, com os elementos de circuito $R_{s}, R_{1 \mathrm{cf}}, R_{2 \mathrm{p}}, R_{3}\left(\mathrm{k} \Omega / \mathrm{cm}^{2}\right)$; $\mathrm{CPE}_{1}, \mathrm{CPE}_{2 \mathrm{dl}}, \mathrm{CPE}_{3}\left(\mu \mathrm{F}_{\mathrm{p}}{ }^{1-n}\right) ; \mathrm{n}_{1 \mathrm{p}}, \mathrm{n}_{2 \mathrm{p}}$ e $\mathrm{n}_{3 \mathrm{p}}$. Os elementos foram designados como resistência da solução $\left(R_{s}\right)$, resistência dos poros $\left(R_{1 p}\right)$, resistência de transferência de carga no substrato $\left(R_{2 p}\right)$ e $R_{3}$ referente aos processos que ocorrem na interface entre camada e substrato, capacitância do revestimento $\left(\mathrm{CPE}_{1}\right),\left(\mathrm{CPE}_{2 \mathrm{dl}}\right.$ e $\left.\mathrm{CPE} \mathrm{E}_{3}\right)$ capacitância de dupla camada nas áreas expostas do substrato.

As resistências $R_{s}, R_{1}$ e $R_{2}$ representam a parte real da impedância e são relacionadas, respectivamente, $R_{s}$ a resistência à corrosão da solução eletrolítica, R1 resistência nos poros do filme orgânico com íons de cério incorporados e $R_{2}$ resistência a transferência de carga. Os elementos capacitivos $\mathrm{CPE}_{1}, \mathrm{CPE}_{2} \mathrm{e}$ $\mathrm{CPE}_{3}$ representam a parte imaginária da impedância e estão relacionadas, respectivamente, a capacitância do filme orgânico com partículas de cério incorporadas, interface da solução com o metal que ocorre via defeitos e processos corrosivos no substrato. Os valores obtidos pelo ajuste dos valores 
obtidos por espectroscopia de impedância eletroquímica foram feitos com o uso do software Zview e os resultados deste ajuste são mostrados na Tabela 11.

Tabela 11: Valores para elementos de circuito elétrico equivalente em função do tempo de imersão em 0,1 mol.L $\mathrm{L}^{-1}$ de $\mathrm{NaCl}$, para a amostra T10.

\begin{tabular}{|c|c|c|c|c|c|c|c|c|}
\hline $\begin{array}{l}\text { Elementos do } \\
\text { circuito }\end{array}$ & $\begin{array}{l}\text { Tempo } \\
\text { (dias) }\end{array}$ & 1 & 2 & 3 & 4 & 5 & 6 & 7 \\
\hline$(\Omega)$ & & 28,5 & 28,1 & 27,8 & 28,6 & 27,3 & 31,7 & 32,5 \\
\hline$\left(\mu \mathrm{F}_{\mathrm{p}}^{1-\mathrm{n}}\right)$ & & 1,89 & 2,71 & 4,68 & 4,80 & 10,1 & 17,5 & 30,2 \\
\hline $\mathbf{n}_{1}$ & & 0,94 & 0,89 & 0,87 & 0,879 & 0,85 & 0,80 & 0,82 \\
\hline$R_{1} \quad\left(\Omega \mathrm{cm}^{-2}\right)$ & & 144,5 & 228 & 215 & 200 & 257 & 302 & 445 \\
\hline $\mathrm{CPE}_{2} \quad\left(\mu \mathrm{F}_{\mathrm{p}}{ }^{1-1}\right.$ & & 1,90 & 4,50 & 13,2 & 42 & 98 & 107 & 174 \\
\hline $\mathbf{n}_{2 p}$ & & 0,89 & 0,84 & 0,87 & 0,72 & 0,72 & 0,65 & 0,43 \\
\hline$\left(\Omega \mathrm{cm}^{-2}\right)$ & & 17260 & 15000 & 8823 & 7912 & 7329 & 6791 & 6084 \\
\hline $\mathrm{CPE}_{3} \quad\left(\mu \mathrm{F}_{\mathrm{p}}^{1-\mathrm{n}}\right)$ & & & 126 & 241 & 273 & 281 & 325 & 805 \\
\hline $\mathbf{n}_{3}$ & & & 0,47 & 0,39 & 0,48 & 0,41 & 0,53 & 0,51 \\
\hline$R_{3} \quad\left(\Omega \mathrm{cm}^{-2}\right)$ & & & 15105 & 12590 & 12000 & 4734 & 3290 & 2648 \\
\hline
\end{tabular}

Os valores $\mathrm{CPE}_{1}$ estão no intervalo de $2 \mu \mathrm{F} \mathrm{cm}^{-2}$ a $30 \mu \mathrm{F} \mathrm{cm}^{-2}$ e sugerem que estes estão relacionados com processos de transferência de carga através dos poros da película orgânica formada na superfície por tratamento de superfície testado. Os valores relativamente baixos de $R_{1}$ (na gama $145 \Omega \mathrm{cm}^{2}-445 \Omega \mathrm{cm}^{2}$ ) sugerem uma camada formada, porém de baixa resistência e defeituosa. Isto foi apoiado pela observação de superfície. Todavia, a resistência aumenta com o tempo de exposição ao eletrólito, devido a precipitação de produtos de corrosão e parcial bloqueio das porosidades do revestimento por estes produtos precipitados.

Isto também é suportado pela diminuição rápida na resistência associada aos produtos de corrosão, formadas nos defeitos na película $\left(R_{2}\right)$, acompanhada pelo rápido aumento nos valores $\mathrm{CPE}_{2}$. $\mathrm{A}$ evolução ao longo do tempo de $\mathrm{CPE}_{2}$ sugere o aumento da contribuição de processos de difusão com o tempo, principalmente por períodos superiores a 5 dias de imersão, provavelmente devido a acúmulo de produtos de corrosão do substrato poroso nas áreas defeituosas de revestimento que impedem a difusão de produtos de corrosão do substrato metálico para o exterior. Este tipo de mecanismo foi proposto na literatura para a corrosão de zinco por Yadav, (YADAV, 2004). 
Os processos de corrosão do revestimento de zinco estão provavelmente relacionados com o par de $\mathrm{CPE}_{3}, \mathrm{R}_{3}$ relacionados aos dados de baixa frequência. Não há indicação de que os processos de baixa frequência associados à corrosão do substrato, seja um tipo de difusão controlada. Isto foi evidenciado durante todo o período de teste, de um a sete dias de imersão. A resistência a ela associada diminui constantemente com o tempo, mas diminuiu significativamente, para menos de metade do seu valor, entre 4 e 5 dias de imersão. $O$ que pode ter sido causado pelas condições mais duras típicas de fendas geradas sob os produtos da corrosão acumulados, porosidade nas áreas defeituosas do revestimento orgânico. O tratamento T10 apresentou valores superiores de resistência à corrosão quando avaliado por Espectroscopia de Impedância Eletroquímica e por teste de corrosão acelerada em câmara de névoa salina.

Os resultados quanto a proteção à corrosão obtidos por analises de impedância eletroquímica e teste de corrosão acelerada em câmara de névoa salina mostraram que os tratamentos adotados foram eficientes uma vez que a resistência à corrosão destes foi superior à superfície sem tratamento. Para o tratamento com 10 minutos de imersão (T10) os resultados se mostraram superiores aos das amostras eletrozincadas com tratamento de conversão de cromato (CCC). Mesmo com resultados apontando proteção a corrosão superior para amostra com o tratamento T10, a evidência de defeitos superficiais que podem comprometer sua eficiência quanto à resistência à corrosão levou a adoção de uma etapa subsequente de tratamento em busca de minimizar estes efeitos e incrementar a proteção à corrosão.

A investigação dos tratamentos propostos permitiu obter respostas para perguntas feitas inicialmente, permitindo afirmar que o tratamento é efetivo na formação de revestimento orgânico com deposição de cério como composto no revestimento e confere proteção à corrosão de aço eletrozincado de baixa liga (automotivo). O pós-tratamento adotado foi 0 de imersão, das amostras preparadas segundo o procedimento denominado T10, sequencialmente em solução de peróxido de hidrogênio, como tentativa de precipitar maior quantidade de íons cério e proporcionar a formação de camada mais compacta, menos defeituosa e mais protetiva contra a corrosão. 


\subsubsection{Efeito do tempo de imersão em solução de peróxido de hidrogênio}

O trabalho teve sequência com a investigação do efeito do tempo de imersão em solução de peróxido de hidrogênio. Os tempos de imersão avaliados foram 1,10 e 20 minutos, e os tratamentos, nomeados, respectivamente como T10_1, T10_10 e T10_20.

O objetivo de introdução desta etapa foi de investigar o papel da solução de peróxido de hidrogênio $\left(\mathrm{H}_{2} \mathrm{O}_{2} \quad 1 \% \mathrm{v} / \mathrm{v}\right)$ na camada formada e, consequentemente, na proteção a corrosão de aço eletrozincado.

Segundo Scholes (SCHOLES, 2006), a imersão em solução de peróxido de hidrogênio ocasiona, em uma primeira etapa, a formação de complexos de $\mathrm{Ce}$ (III) ou peroxo complexos de fórmula química $\mathrm{Ce}\left(\mathrm{H}_{2} \mathrm{O}_{2}\right)^{3+}$. Esta formação é seguida por desprotonação, oxidação e precipitação, para formar peroxicomplexos contendo $\mathrm{Ce}(\mathrm{IV})$ na forma $\mathrm{Ce}(\mathrm{IV})\left(\mathrm{O}_{2}\right) \cdot(\mathrm{OH})_{2}$. O efeito da oxidação dos compostos de cério por peróxido de hidrogênio, os quais foram incorporados na camada formada é o aumento no desempenho das superfícies contendo cério, frente à corrosão. Algumas questões pertinentes a esta fase da pesquisa são:

1) A adição da etapa de imersão em peróxido de hidrogênio modifica o filme formado pelo tratamento T10 (Cério) sobre o aço eletrozincado?

2) A imersão em peróxido de hidrogênio causa incremento de cério no filme formado?

Nas seções seguintes procurar-se-á responder a essas questões.

5.3.2.1. Morfologia (Microscopias de Emissão, Microscopia Óptica tridimensional) e Difração de raios $X$

Micrografias obtidas por microscopia de emissão (FEG), para as amostras tratadas em soluções de conversão T10 (referência) e T10_1 (amostra T10 póstratada por 1 minuto de imersão em solução de peróxido de hidrogênio) são apresentadas na Figura 34, A e B, respectivamente. 

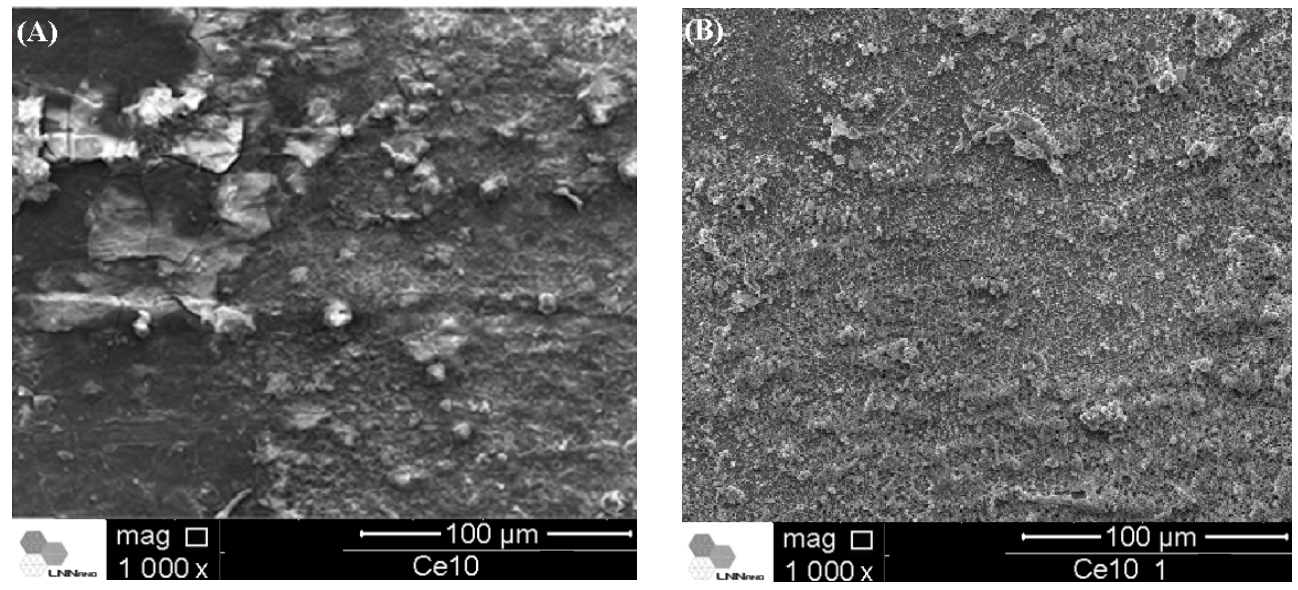

Figura 34: Micrografias obtidas por FEG das superfícies tratadas por imersão em soluções: A) amostra com tratamento T10 (sem imersão em peróxido; B) amostra com tratamento T10_1.

A micrografia da amostra T10_1 mostra uma superfície rugosa e irregular, mas, quando comparada com a superfície da amostra sem tratamento com peróxido, é possível observar que o recobrimento torna-se mais uniforme. As micrografias obtidas por microscopia de emissão (FEG) para as superfícies das amostras após os tratamentos T10_10 (amostra T10 pós-tratada por 10 minutos de imersão em solução de peróxido de hidrogênio) e T10_20 (amostra T10 póstratada por 20 minutos de imersão em solução de peróxido de hidrogênio) são apresentadas na Figura 35, A e B, respectivamente.
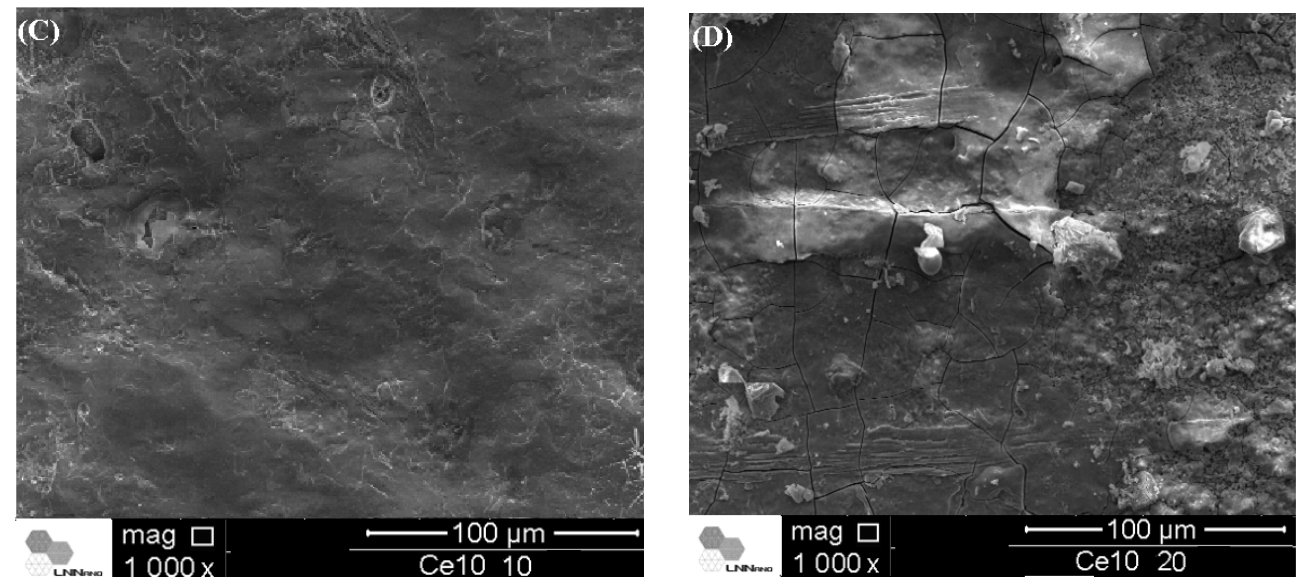

Figura 35: Micrografias obtidas por FEG para amostras tratadas por imersão em soluções de peróxido de hidrogênio por: A) 10 minutos, amostra com tratamento T10_10; B) 20 minutos, amostra com tratamento T10_20. 
A superfície da amostra imersa por 20 minutos em solução de peróxido de hidrogênio mostra a presença de defeitos grandes e em várias regiões da superfície. Os defeitos, neste caso, são maiores e mais numerosos até mesmo que os defeitos apresentados pelo tratamento de conversão de cromatos.

Dentre os tempos de imersão em solução de peróxido de hidrogênio testados, o tempo de 10 minutos foi considerado o mais efetivo para a formação de filme ao longo de toda a superfície com menor concentração de defeitos. Aparentemente a imersão em solução de peróxido de hidrogênio favoreceu a formação de filme mais compacto, que cobre parcialmente os defeitos formados nas amostras obtidas pelo tratamento T10.

A proposta de imersão, nesta solução oxidante, se mostrou eficiente para a formação de filme mais uniforme e com menos defeitos. Para avaliar a rugosidade da superfície pós-tratamentos, foram obtidas imagens tridimensionais por microscopia óptica com aumento de 50 vezes, para amostras pós-tratadas em solução de peróxido de hidrogênio e as imagens são apresentadas na Figura 36, (A) amostra com tratamento T10, (B) amostra com tratamento T10_1. (C) amostra com tratamento T10_10 e (D) amostra com tratamento T10_20.

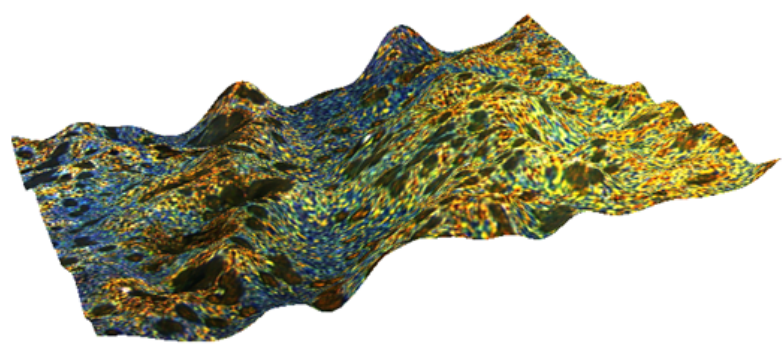

(A)

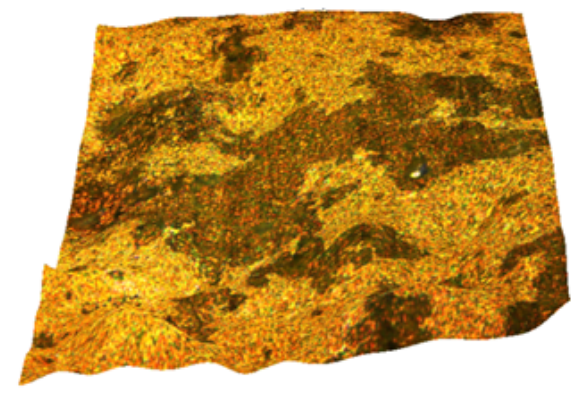

(B) 


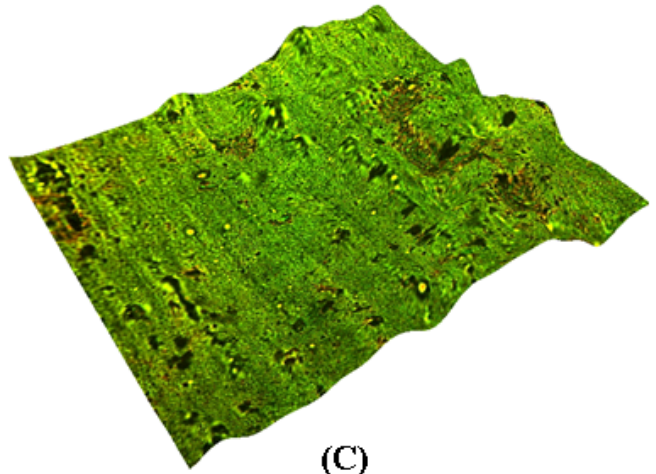

(C)

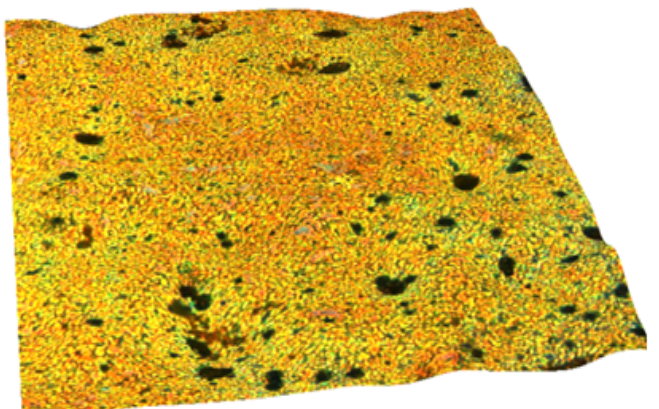

(D)

Figura 36: Micrografia ótica tridimensional para as amostras T10 (A), com diferentes tempos de imersão em peróxido de hidrogênio por: B) 1 minuto, amostra com tratamento T10_1, (C) 10 minutos, amostra com tratamento T10_10, e (D) amostra com tratamento T10_20.

O tempo de imersão de 1 minuto em solução de peróxido de hidrogênio (T10_1) mostrou-se insuficiente para formação de filme, comparativamente aos tempos de 10 e 20 minutos. Por isso o tempo de 1 minuto de imersão em solução de peróxido de hidrogênio foi considerado insuficiente para formação de camada uniforme.

O aumento do tempo de tratamento de 1 para 10 minutos torna a superfície ainda mais regular, porém quando se usou tempo de imersão de 20 minutos, o que causou número de defeitos acentuado. $\mathrm{O}$ tempo de 10 minutos foi o que produziu uma camada com menos defeitos e, portanto superfície mais homogênea dentre as testadas (amostra T10_10).

O tratamento T10_10 foi escolhido para dar continuidade às pesquisas de desenvolvimento de um filme orgânico protetor. A técnica de Difração de Raios $X$ foi utilizada para caracterizar a superfície após tratamentos (T10_1, T10_10 e T10_20), e os resultados são mostrados na Figura 37. 


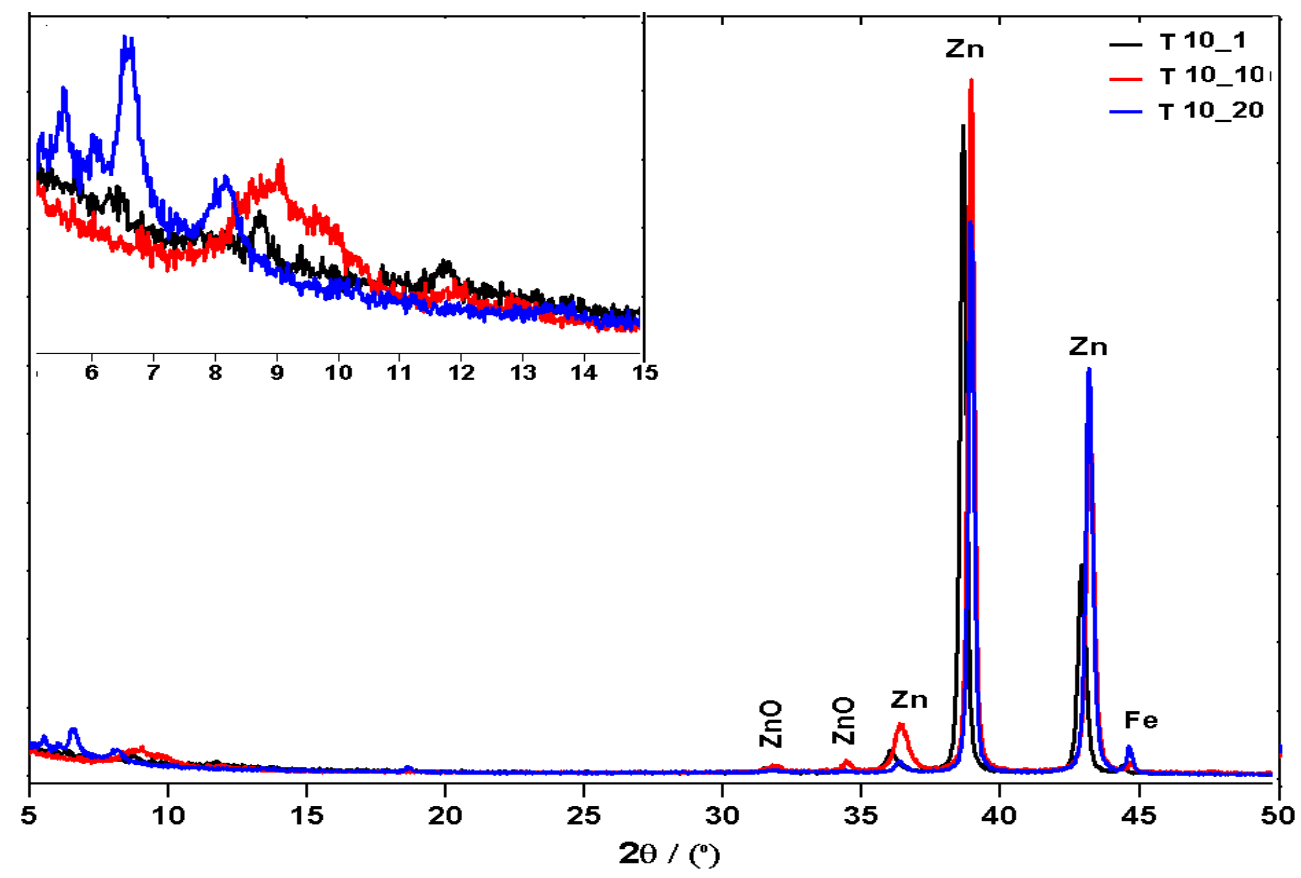

Figura 37: Difratogramas obtidos por difração de raios $X(X R D)$ para as amostras com tratamentos T10_1, T10_10 e T10_20, respectivamente imersas por 1, 10 e 20 minutos em solução de peróxido de hidrogênio.

Os difratogramas das amostras com os tratamentos T10_1, T10_10 e T10_20 mostram a presença de fases cristalográficas do substrato (Zn) típicas de zinco, entre $35^{\circ}$ e $45^{\circ}$. Os difratogramas permitem observar a presença de picos de alta intensidade, correspondentes ao substrato de aço eletrozincado, picos em $36^{\circ}, 38,5^{\circ}, 42,7^{\circ}$ e picos de menor intensidade em $32^{0}$ e $34^{\circ}$ e $44,8^{\circ}$. Os picos de mais alta intensidade são identificados como pertencentes ao zinco eletrodepositado.

Os demais picos evidenciados, em $36^{\circ}, 38,5^{\circ}$, foram identificados como fases do zinco e, o pico em $44,8^{\circ}$, como fase do ferro, aço. Os picos observados em baixo ângulo $\left(5^{\circ}\right.$ e $\left.10^{\circ}\right)$ mostrados nos difratogramas da Figura 36, também foram observados amostras nos tratamentos de imersão em solução contendo cério, Figura 20. Estes picos não puderam ser identificados.

Os resultados mostraram uma diferença entre as superfícies analisadas, e pela ausência de sinal para pico referente ao substrato de zinco $\left(35,9^{0}\right)$, para a amostra com tratamento T10_10, sugere que a camada é mais densa, comparativamente às amostras em que não houve pós-tratamento de imersão em 
peróxido de hidrogênio. Os resultados de difração de raios $X$ foram inconclusivos quanto à presença de cério na camada formada. Na busca de respostas quanto à relação entre tempo de imersão em solução de peróxido de hidrogênio e constituição do filme, foi realizada a caracterização química por espectroscopia no Infravermelho e espectroscopia fotoeletrônica de raios $X$ e os resultados são apresentados a seguir.

5.3.2.2. Análise da composição química (Espectroscopia no Infravermelho por Transformada de Fourier e Espectroscopia Fotoeletrônica de Raios X).

Os espectros no infravermelho FTIR para as superfícies após os tratamentos T10_1, T10_10 e T10_20 são mostrados na Figura 38.

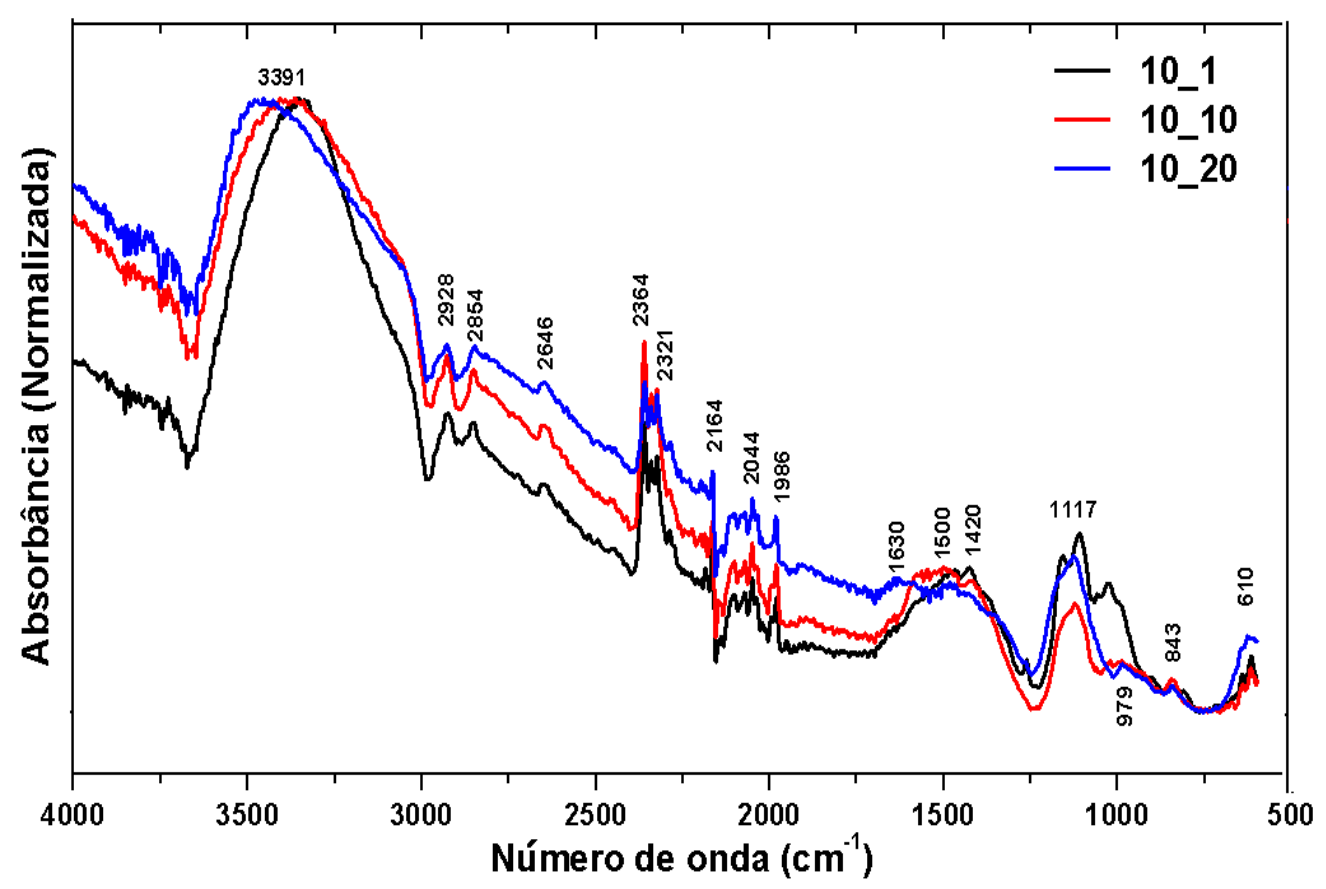

Figura 38: Espectros normalizados de FTIR para as superfícies do aço eletrozincado após os tratamentos T10_1, T10_10 e T10_20.

A interpretação dos espectros obtidos foi feita com a constatação de bandas características de grupos funcionais $\mathrm{C}=\mathrm{O}\left(1800 \mathrm{~cm}^{-1}\right.$ a $\left.1600 \mathrm{~cm}^{-1}\right), \mathrm{OH}$ $\left(3500 \mathrm{~cm}^{-1}\right.$ a $\left.3200 \mathrm{~cm}^{-1}\right)$, banda larga para $\mathrm{OH}$ de ácidos $\left(3400 \mathrm{~cm}^{-1}\right.$ a $\left.2700 \mathrm{~cm}^{-1}\right)$, C-O $\left(1300 \mathrm{~cm}^{-1}-1000 \mathrm{~cm}^{-1}\right), \mathrm{C}-\mathrm{H}$ alifáticos saturados $\left(3000 \mathrm{~cm}^{-1}-2800 \mathrm{~cm}^{-1}\right)$, $=\mathrm{C}-\mathrm{H}$ insaturados $\left(3100 \mathrm{~cm}^{-1}-3300 \mathrm{~cm}^{-1}\right)$ entre outras (PAVIA, 2010). 
Para todos os espectros no infravermelho, houve correspondência quanto aos picos ou bandas de absorbância presentes. Foram observadas bandas de absorção em $610 \mathrm{~cm}^{-1}, 843 \mathrm{~cm}^{-1}, 979 \mathrm{~cm}^{-1}, 1117 \mathrm{~cm}^{-1}, 1420 \mathrm{~cm}^{-1}, 1500 \mathrm{~cm}^{-1}, 1630$ $\mathrm{cm}^{-1}, 1986 \mathrm{~cm}^{-1}, 2120 \mathrm{~cm}^{-1}, 2044 \mathrm{~cm}^{-1}, 2164 \mathrm{~cm}^{-1}, 2231 \mathrm{~cm}^{-1}, 2364 \mathrm{~cm}^{-1}, 2864 \mathrm{~cm}$ 1, $2928 \mathrm{~cm}^{-1}, 3391 \mathrm{~cm}^{-1}$. Estes resultados comprovam que os filmes formados apresentam constituição química semelhante após tratamento por diferentes tempos de imersão em solução de peróxido de hidrogênio. Também foi possível observar a correspondência dos espectros no FTIR aqui observados, com os apresentados para as amostras sem tratamento de imersão em peróxido de hidrogênio, isto é, amostras com tratamentos T1, T10 e T20 (Figura 21).

A observação destes picos, em grande parte semelhantes ou com número de ondas próximos, permite afirmar que o tratamento de oxidação por imersão em solução de peróxido de hidrogênio praticamente não altera a constituição química da camada formada. Isto é visto quando se compara a amostra T10, sem imersão em solução de peróxido de hidrogênio com as amostras com diferentes tempos de imersão em solução de peróxido de hidrogênio.

Mesmo sendo semelhantes quanto à posição (número de onda), ocorrem variações nas intensidades destes picos, alguns em quantidades diretamente proporcionais ao tempo de imersão (caso das bandas de absorbância aproximadas em $610 \mathrm{~cm}^{-1}, 2048 \mathrm{~cm}^{-1}$, e $2159 \mathrm{~cm}^{-1}$ ), relações inversamente proporcionais (caso das bandas de valência em $843 \mathrm{~cm}^{-1}, 979 \mathrm{~cm}^{-1}, 1430 \mathrm{~cm}^{-1}$, $1500 \mathrm{~cm}^{-1}$ e $3391 \mathrm{~cm}^{-1}$ ) e bandas de absorção sem padrão na variação, caso das bandas em $1117 \mathrm{~cm}^{-1}, 1986 \mathrm{~cm}^{-1}, 2321 \mathrm{~cm}^{-1}, 2368 \mathrm{~cm}^{-1}, 2646 \mathrm{~cm}^{-1}$ e $2842 \mathrm{~cm}^{-1}$.

Bandas de absorção representadas por picos localizados em $610 \mathrm{~cm}^{-1} \mathrm{e}$ $2842 \mathrm{~cm}^{-1}$, são relacionados com o cério na forma de óxido e de nitrato, respectivamente. Estas permitem observar que há aumento na quantidade de cério no filme formado em função do tempo de imersão em solução de peróxido de hidrogênio, o que atesta a eficiência do tratamento de imersão em solução de peróxido de hidrogênio na precipitação de cério no filme formado.

Entende-se que o pico, de intensidade diretamente proporcional ao tempo de imersão, $610 \mathrm{~cm}^{-1}$, é mais representativo na presença de cério do que o pico 
$2842 \mathrm{~cm}^{-1}$. Estimativa de quantidade de cério é possível neste caso. Picos em cerca de $1117 \mathrm{~cm}^{-1}$ e entre $1400 \mathrm{~cm}^{-1} \mathrm{e} 1500 \mathrm{~cm}^{-1}$ correspondem ao modo vibracional do carbonato de zinco $\left(\mathrm{ZnCO}_{3}\right)$.

As espécies orgânicas presentes no filme formado são representadas pelos picos com bandas de absorção em $850 \mathrm{~cm}^{-1}\left(-\mathrm{CH}_{3}\right), 992 \mathrm{~cm}^{-1}\left(\mathrm{CH}_{2}-\right), 1120 \mathrm{~cm}^{-1}$ ($\left.\mathrm{CH}_{3}\right), 1980 \mathrm{~cm}^{-1}$ e $2120 \mathrm{~cm}^{-1}(\mathrm{H}-\mathrm{C}=\mathrm{O})$. Estes resultados mostram que partes da molécula do precursor polimérico, ou de outra estrutura orgânica, originária do mesmo, foram incorporadas na superfície (SOCRATES, 1994).

Os picos, aproximados, entre $1000 \mathrm{~cm}^{-1} \mathrm{e} 1200 \mathrm{~cm}^{-1}$ estão relacionados à ligação entre carbono e oxigênio (C-O). A ligação entre carbono, oxigênio e hidrogênio (C-O-H), corresponde ao estiramento das ligações do grupo carboxil (COO). As intensidades destas bandas de absorção são muito próximas para os tempos de imersão de 1 e 20 minutos, mostrando que estes grupos estão presentes em maior quantidade, comparativamente à amostra com tratamento T10_10.

A imersão em solução de peróxido de hidrogênio propícia a deposição de grupos carboxil sobre a camada orgânica pré-existente. Os picos presentes entre $1300 \mathrm{~cm}^{-1}, 1500 \mathrm{~cm}^{-1} \mathrm{e} 1650 \mathrm{~cm}^{-1}$, reportados como ligante bidentado do grupo carboxil reforçam a hipótese de presença de uma das espécies propostas na via reacional, os ácidos propanóico e ou but-2enóico.

Análises por XPS permitiram a obtenção de resultados qualitativos e quantitativos quanto aos elementos presentes na camada formada. Os espectros gerais das camadas obtidas são mostrados na Figura 39, para os tratamentos T10_1, T10_10 e T10_20. 


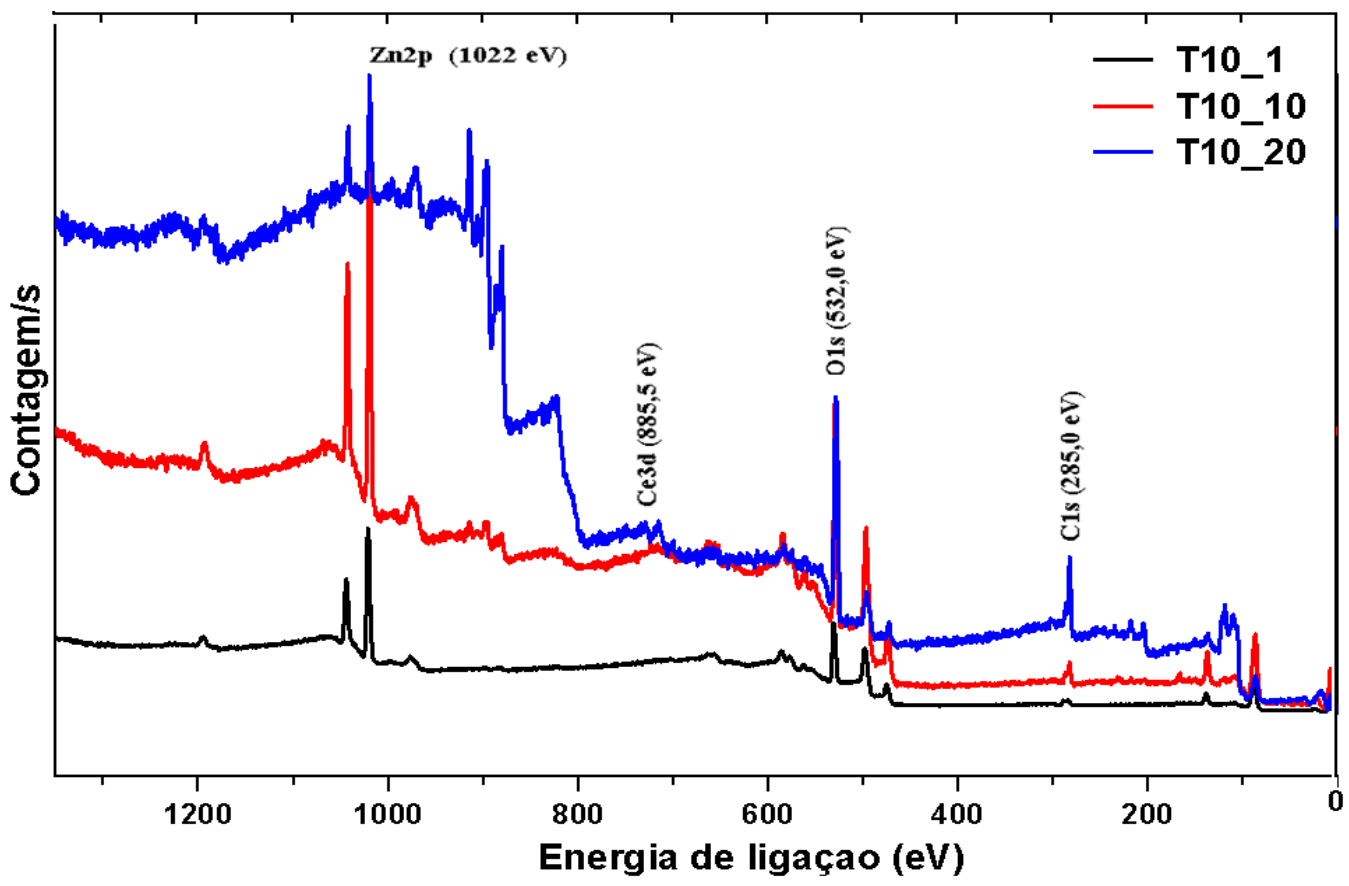

Figura 39: Espectro geral obtido por Espectroscopia Fotoeletrônica de raios $X$ (XPS) da camada formada em superfície de aço eletrozincado, amostras com tratamento T10 imersas em solução de peróxido de hidrogênio por 1, 10 e 20 minutos, respectivamente tratamentos T10_1, T10_10 e T10_20.

O espectro geral obtido por XPS permite observar a presença dos elementos carbono (C1s, $285 \mathrm{eV})$, do filme orgânico, oxigênio (O 1s, $532 \mathrm{eV})$, zinco (Zn2p3/2, $1022 \mathrm{eV})$ e cério (Ce3d5/2, $885 \mathrm{eV})$, e picos Auger não referenciados. Os elementos observados foram os mesmos que para as amostras sem pós-tratamento em peróxido de hidrogênio (T10) e, por isso, pode-se afirmar que o tratamento de imersão em peróxido de hidrogênio não altera a composição química da camada formada. Há apenas pequenas alterações nos números de oxidação de algumas espécies químicas identificadas.

Estes espectros iniciais permitiram a obtenção de espectros de maior resolução (maior número de varreduras) para cada uma das espécies observadas. Os picos, energias de ligação, fator de ajuste (FWHM) e concentrações atômicas por elementos são mostrados na Tabela 12. 
Tabela 12. Picos, energias de ligação, fatores de ajuste (FWHM) e concentrações atômicas obtidas por XPS, das amostras T10_1, T10_10 e T10_20.

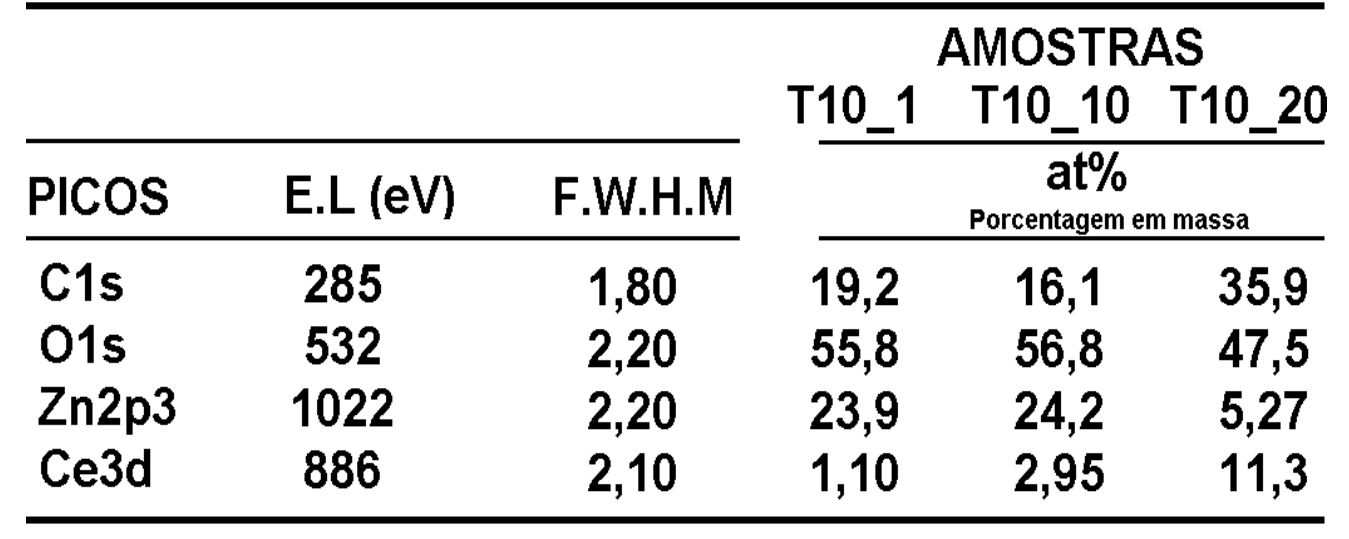

Os resultados mostram que as superfícies apresentam teores de carbono menores que os observados para as amostras sem pós-tratamento por imersão em solução de peróxido de hidrogênio (amostras T1, T10 e T20). O maior teor de carbono associado à amostra T10_20 pode ser atribuído à formação de produtos de corrosão do zinco, na forma de carbonato de zinco, em excesso devido ao tempo excessivo de exposição à solução ácida de tratamento apresentado pela amostra T10_20, o que apoia a observação acima.

Como observado na caracterização morfológica (Figuras 33 a 35) a imersão em solução de peróxido de hidrogênio promove a formação de camada mais espessa, comparativamente à amostra com tratamento T10. $\mathrm{O}$ tratamento de imersão em solução de peróxido de hidrogênio se mostrou efetivo na formação de camada mais protetora na superfície do substrato.

Para eliminar a influência de espécies superficiais contaminantes, uma segunda etapa, foi realizada, qual seja a aquisição de perfil de profundidade, onde espécies fracamente adsorvidas são removidas por íons argônio e novos espectros são obtidos em diferentes níveis de profundidade, em função do tempo de "sputtering". A Figura 40 mostra o perfil de profundidade obtido em função do tempo de incidência de íons argônio (sputtering) representados pelos espectros dos elementos componentes do filme, sobrepostos, para a amostra T10_10. 


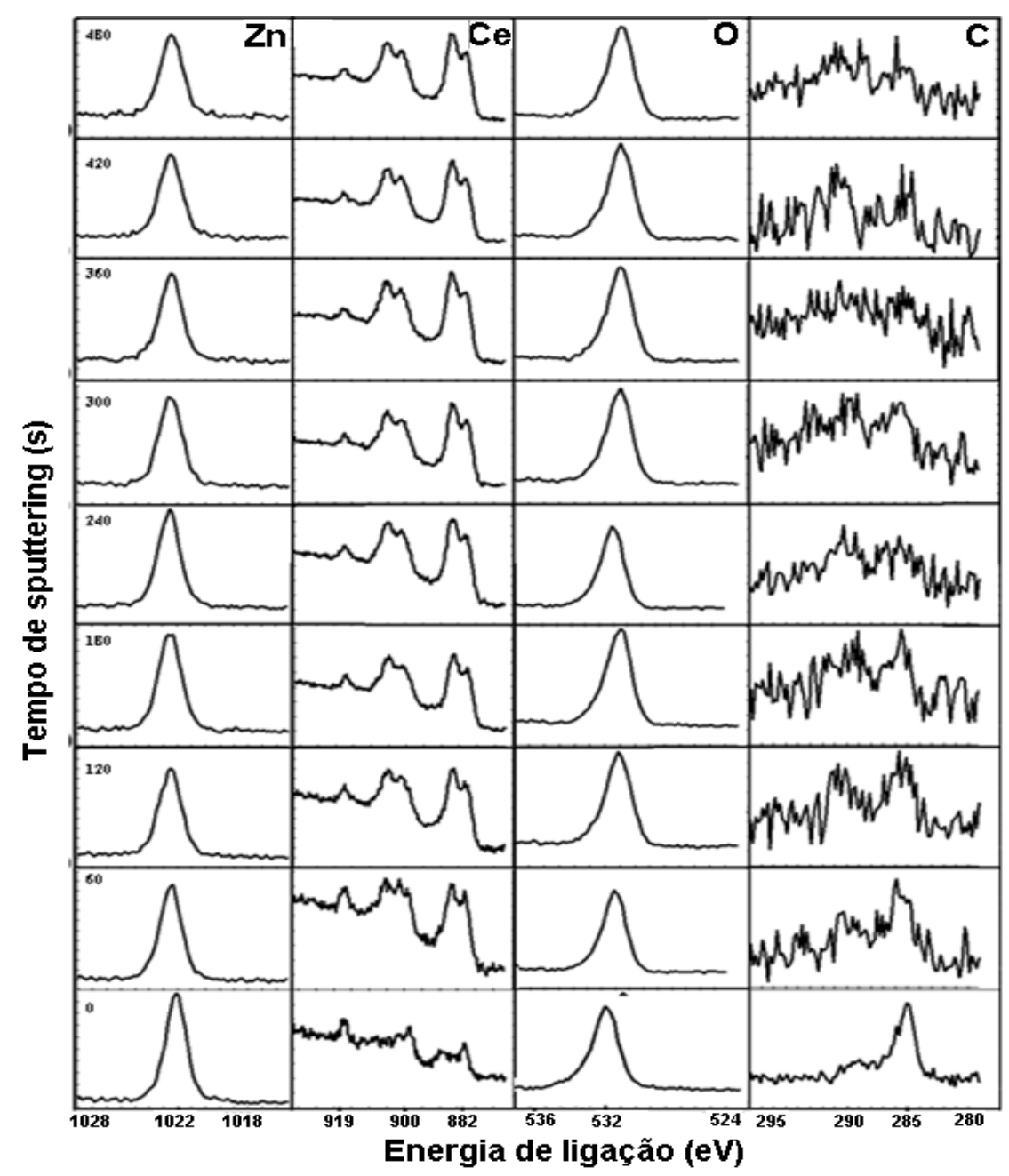

Figura 40: Espectros obtidos por Espectroscopia Fotoeletrônica de raios X (XPS) para elementos C1s, O1s, Ce3d e Zn2p obtidos em função do tempo de "sputtering" (em segundos) da superfície do aço eletrozincado após tratamento por imersão da amostra T10 em solução de peróxido de hidrogênio por 10 minutos, amostra com tratamento T10_10.

Os espectros permitem observar dois picos posicionados em 285 eV e 290 eV para o carbono C1s. Os picos em 285 eV são associados às ligações C-C e C$\mathrm{H}$. Estes, quando presentes na forma de compostos contaminantes adsorvidos, são removidos em tempos reduzidos de "sputtering". A permanência deste carbono após tempos longos de "sputtering" é justificada como sendo pertencente às ligações $\mathrm{C}-\mathrm{C}$ e $\mathrm{C}-\mathrm{H}$ dos ácidos carboxílicos ligados ao substrato por ligações fortes, ligações covalentes e, portanto, de difícil remoção. As concentrações atômicas, picos, energias de ligação e fatores de ajuste para elemento carbono, obtidas por XPS em função do tempo de "sputtering" (s), para as amostras 
T10_10, 10 minutos em solução de peróxido de hidrogênio são mostradas na Tabela 13.

Tabela 13: Concentrações atômicas e fatores de ajuste para C1s, obtidas por XPS em função do tempo de "sputtering" (s), para as amostras T10_10.

\begin{tabular}{lccccc}
\hline $\begin{array}{l}\text { Tempo etch (s) } \\
\text { C1s (fitting) }\end{array}$ & 0 & 60 & 240 & 300 & 480 \\
TRAT. T10_10 & \multicolumn{5}{c}{$\begin{array}{c}\text { at\% } \\
\text { porcentagem em massa }\end{array}$} \\
\cline { 2 - 6 } C-C/C-H & 21,6 & 25,7 & 16,4 & 9,5 & 31,9 \\
C-O/C-OH & 5,80 & 16,7 & 8,9 & 17,0 & 9,7 \\
C=O & 59,7 & 33,6 & 23,2 & 6,8 & 22,2 \\
O-C=O & 12,8 & 24,0 & 51,5 & 66,7 & 36,2 \\
\hline
\end{tabular}

Os resultados para as diferentes formas ligantes do carbono ao longo da camada, em função da profundidade, mostram que estes podem ser representados por $\mathrm{C}-\mathrm{C} / \mathrm{C}-\mathrm{H}$, associados a carbonos alifáticos de espécies fracamente adsorvidas, ou de parte da cadeia carbônica do filme orgânico depositado, $\mathrm{C}-\mathrm{O} / \mathrm{C}-\mathrm{OH}, \mathrm{C}=\mathrm{O}$ e $\mathrm{O}-\mathrm{C}=\mathrm{O}$, todas relacionadas à parte das cadeias carbônicas do filme, mais especificamente, da função ácido carboxílico.

Há uma grande variação da concentração para estas formas químicas do carbono. No entanto, ao se observar a concentração em função do tempo de "sputtering", 0 e 480 segundos, observa-se um aumento na concentração. $O$ carbono $\mathrm{C}-\mathrm{C} / \mathrm{C}-\mathrm{H}$, referente a espécies contaminantes, é removido após 60 segundos e, para o maior tempo de "sputtering" (480 s), são evidenciadas partes de grupos funcionais que fazem parte do ácido carboxílico ligado ao substrato. Concentrações atômicas, picos, energias de ligação e fatores de ajuste para elemento oxigênio, obtidas por XPS em função do tempo de "sputtering" (s), para a amostra com tratamento T10_10, são mostrados na Tabela 14. 
Tabela 14: Concentrações atômicas, e ajustes para O1s, obtidas por XPS em função do tempo de "sputtering" (s), amostra com tratamento T10_10.

\begin{tabular}{lccccc}
\hline $\begin{array}{l}\text { Tempo etch (s) } \\
\text { O1s (fitting) }\end{array}$ & 0 & 60 & 240 & 300 & 480 \\
TRAT. T10_10 & \multicolumn{5}{c}{$\begin{array}{c}\text { at\% } \\
\text { porcentagem em massa }\end{array}$} \\
\cline { 2 - 6 } O $^{2-}$ & 85,8 & 84,9 & 49,5 & 58,7 & 54,3 \\
OH. & 12,3 & 13,9 & 48,5 & 39,8 & 45,0 \\
$\mathrm{H}_{2} \mathrm{O}$ & 1,9 & 1,2 & 2,0 & 1,5 & 0,7 \\
\hline
\end{tabular}

Os resultados para o ajuste do pico $\mathrm{O}$ 1s mostram concentração de oxigênio na forma de $\mathrm{H}_{2} \mathrm{O}$, espécie adsorvida. Em estágios de oxidação do zinco há adsorção de água e formação de complexos hidratados. A presença de oxigênio na forma óxido é predominante, em praticamente todos os tempos de "sputtering" usados, mostrando que o pós-tratamento de imersão em peróxido de hidrogênio é eficiente na formação de óxidos junto ao substrato. Os hidróxidos são, quase que exclusivamente, atribuídos a $\mathrm{Zn}(\mathrm{OH})_{2}$. Concentrações atômicas, picos, energias de ligação e fatores de ajuste para elemento zinco, obtidas por XPS em função do tempo de "sputtering" (s), para as amostras T10_10, são mostradas na Tabela 15.

Tabela 15: Concentrações atômicas e fatores de ajuste para Zn2p, obtidas por XPS em função do tempo de "sputtering" (s), para as amostras T10_10.

\begin{tabular}{|c|c|c|c|c|c|}
\hline $\begin{array}{l}\text { Tempo etch (s) } \\
\text { Zn2p (fitting) } \\
\text { TRAT. T10_10 }\end{array}$ & 0 & porcen & $\begin{array}{c}\text { at } \% \\
\text { tagem em }\end{array}$ & 300 & 480 \\
\hline $\begin{array}{l}\text { Zn (Metal) } \\
\mathrm{ZnO} \\
\mathrm{Zn}(\mathrm{OH})_{2}\end{array}$ & $\begin{array}{l}4,40 \\
82,5 \\
13,1\end{array}$ & $\begin{array}{c}2,0 \\
92,8 \\
5,2\end{array}$ & $\begin{array}{c}2,6 \\
96,7 \\
0,7\end{array}$ & $\begin{array}{c}1,4 \\
94,2 \\
4,6\end{array}$ & $\begin{array}{l}26,0 \\
62,0 \\
12,0\end{array}$ \\
\hline
\end{tabular}

Os resultados do ajuste para o pico de zinco mostram a eficiência do "sputtering" usado, com a remoção de material mostrada pelo incremento na quantidade de zinco metálico em função do tempo de "sputtering". A superfície da amostra com tratamento T10_10 apresenta o zinco distribuído ao longo de toda a extensão da camada formada, principalmente na forma de óxido, mostrado pelos 
teores de zinco encontrados na superfície e próximo ao substrato. As concentrações atômicas, picos, energias de ligação e fatores de ajuste para o elemento cério, obtidas por XPS em função do tempo de "sputtering" (s), para a amostra T10_10, mostrados na Tabela 16.

Tabela 16: Concentrações atômicas e fatores de ajuste para Ce3d, obtidas por XPS em função do tempo de "sputtering" (s), para as amostras T10_10.

\begin{tabular}{lccccc}
\hline $\begin{array}{l}\text { Tempo etch (s) } \\
\text { Ce3d (fitting) }\end{array}$ & 0 & 60 & 240 & 300 & 480 \\
TRAT. T10_10 & \multicolumn{5}{c}{$\begin{array}{c}\text { at\% } \\
\text { porcentagem em massa }\end{array}$} \\
\cline { 2 - 6 } Ce III & 45,6 & 58,7 & 60,1 & 42,0 & 39,1 \\
Ce IV & 54,4 & 41,3 & 39,9 & 58,0 & 60,9 \\
\hline
\end{tabular}

Os picos referentes a cério em dois estados de oxidação aparecem em uma faixa de energia de ligação entre 880 eV e 920 eV. As análises com até 480 segundos de "sputtering" permitiram observar picos centrados $919 \mathrm{eV}$, indicando a presença de $\mathrm{Ce}^{4+}$ na forma de óxido tetravalente $\left(\mathrm{CeO}_{2}\right)$. A presença de cério e sua continuidade com o tempo de "sputtering" prolongado sugerem que o cério esteja fortemente ligado (ligação covalente) a oxigênio de sítios de óxido de zinco do substrato.

Pode-se afirmar que houve a formação de um filme orgânico fino com os óxidos de cério III e IV $\left(\mathrm{Ce}_{2} \mathrm{O}_{3}\right.$ e $\left.\mathrm{CeO}_{2}\right)$ incorporados. A quantidade destes óxidos varia com a profundidade ou em direção ao substrato de zinco. Quanto mais internamente na camada formada, predomina cério na forma de óxido tetravalente $\left(\mathrm{CeO}_{2}\right)$. Portanto, pode-se concluir que o pós-tratamento por imersão em solução de peróxido de hidrogênio foi eficiente na deposição de cério, óxido tetravalente, de menor solubilidade, e, portanto, mais efetivo na proteção contra a corrosão.

5.3.2.3. Resultados eletroquímicos (Ensaios de corrosão acelerada e Espectroscopia de Impedância Eletroquímica).

Os resultados obtidos em câmara de névoa salina são apresentados na Tabela 17, indicando os tempos observados para corrosão branca, aparecimento 
da corrosão vermelha e ocupação de 10\% por produtos de corrosão vermelha.

Tabela 17: Tempos de exposição em câmara de névoa salina para as amostras de zinco, cromato, e os tratamentos investigados em função do tempo de imersão, tratamentos T10, T10_1, T10_10 e T10_20.

\section{Tempo (h) - Aparecimento de corrosão}

\begin{tabular}{lccc}
\cline { 2 - 4 } Tratamentos & $\begin{array}{c}\text { Corrosão } \\
\text { branca }\end{array}$ & $\begin{array}{c}\text { Corrosão } \\
\text { vermelha }\end{array}$ & $\begin{array}{c}\text { Corrosão } \\
\text { vermelha } \\
\text { 10\% }\end{array}$ \\
\hline Zinco & 8 & 75 & 80 \\
Zinco+CCC & 96 & 240 & 250 \\
Zinco+T10 & 120 & 336 & 400 \\
Zinco+T10_1 & 110 & 192 & 218 \\
Zinco+T10_10 & 144 & 290 & 380 \\
Zinco+T10_20 & 168 & 200 & 216 \\
\hline
\end{tabular}

Os resultados evidenciam que o revestimento de zinco puro apresenta tempos reduzidos de proteção à corrosão e que estes tempos são maiores quando sobre o mesmo são formados revestimentos propostos. Todas as amostras com revestimentos propostos apresentaram tempos superiores aos tratamentos de cromatos, para a formação de produtos de corrosão branca. Estes resultados são argumentos que apontam a potencialidade dos tratamentos propostos. Para tratamentos com 10 minutos (amostra T10_10) os valores mostraram resistência por mais tempo, tanto para a formação de produtos de corrosão e sua evolução até $10 \%$ da superfície total da amostra.

O tratamento T10_20, embora tenha apresentado o mais alto valor de tempo para a corrosão branca, dentre os tratamentos propostos, o tempo para formação de produtos de corrosão vermelha foi inferior ao tratamento de referência, cromato. A presença de filme orgânico dificulta a formação de produtos iniciais de corrosão, no entanto, após a formação destes produtos 0 processo de corrosão é acelerado, provavelmente pelos defeitos superficiais formados. Os defeitos possibilitam a penetração de maior quantidade de eletrólito e ataque mais efetivo do substrato de zinco.

A evolução da impedância eletroquímica, para as amostras de aço 
eletrozincado após tratamentos T10_1, T10_10 e T10_20 é apresentada nas Figuras 41 e 42, na forma de diagramas de Nyquist para diferentes tempos de contato com solução de cloreto de sódio $0,1 \mathrm{~mol}^{-\mathrm{L}^{-1}}$, especificamente 1; 3; 5 e 7 dias.
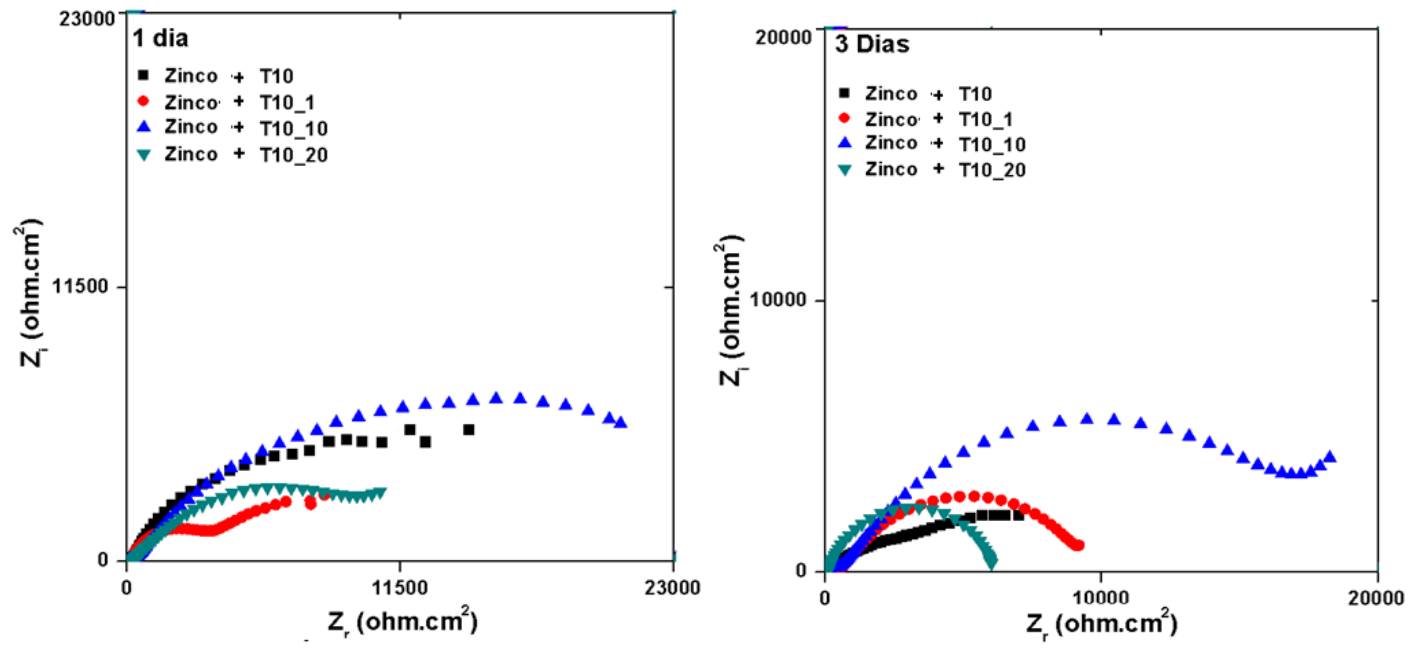

Figura 41: Diagramas de Nyquist para 1 e 3 dias de imersão em solução 0,1 mol. $\mathrm{L}^{-1}$ de $\mathrm{NaCl}$, das amostras com tratamentos T10, T10_1, T10_10 e T10_20.

Os resultados da Figura 41 mostraram que os processos de interação entre as amostras e o eletrólito promovem degradação da superfície e, consequentemente, diminuição da impedância, além de modificações nos mecanismos sugeridos pela alteração nas formas das curvas de impedância. Os diagramas de Nyquist para a amostra T10_10, mostram que entre 1 e 3 dias de imersão há pequena variação nos valores de impedância e modificação nos processos a baixas frequências com a definição de um arco a médias frequências e a indicação de processos difusionais.

O tratamento por imersão em solução de peróxido de hidrogênio mostrou que para o primeiro dia de imersão, os valores de impedância eletroquímica apenas da amostra T10_10 foram maiores que da amostra de referência, mas após 3 dias de imersão em solução de cloreto, apenas o tratamento por 20 minutos de imersão em peróxido de hidrogênio se mostrou menor que o tratamento de referência (amostra T10). 

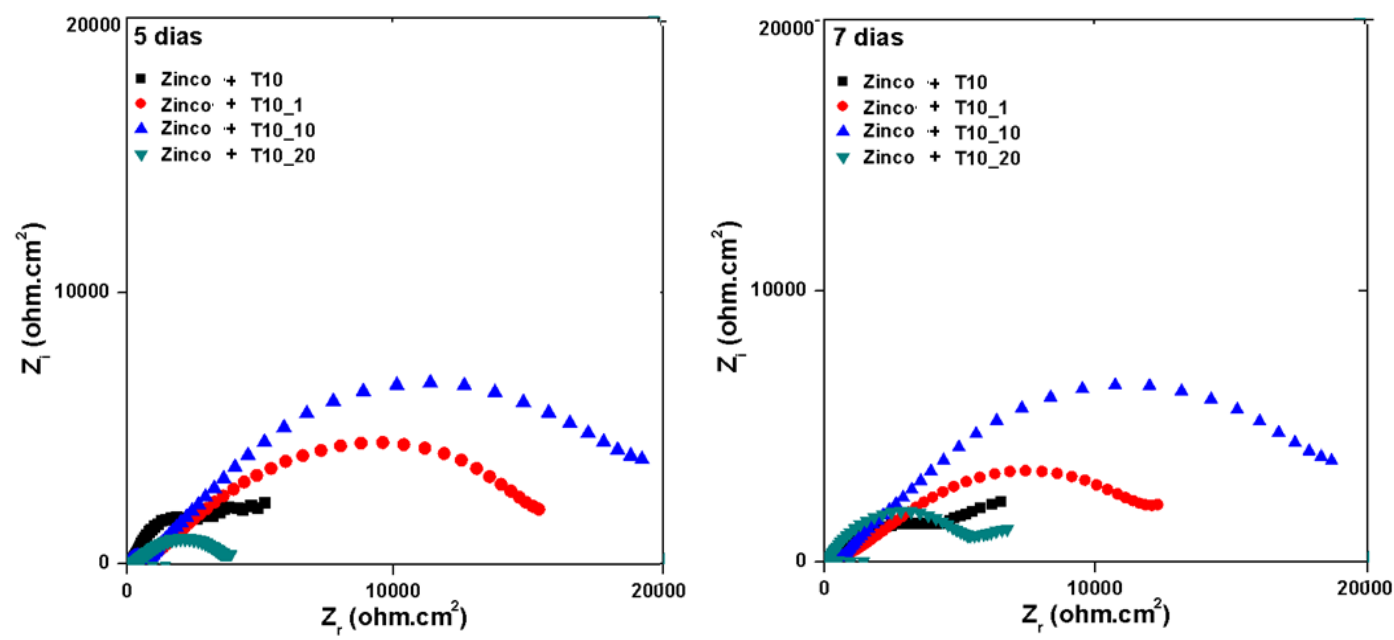

Figura 42: Diagramas de Nyquist para 5 e 7 dias de imersão em solução 0,1 mol. $\mathrm{L}^{-1}$ de $\mathrm{NaCl}$, das amostras com tratamentos T10, T10_1, T10_10 e T10_20.

Os resultados de impedância eletroquímica de 5 e 7 dias, diagramas de Nyquist para as amostras T10, T10_1, T10_10 e T10_20 mostram que os processos de interação entre as amostras e o eletrólito promovem a redução dos valores de impedância para as amostras T10 e T10_20. A amostra T10 foi usada como referência, uma vez que o pós-tratamento de imersão em peróxido tem como base a amostra T10. O tempo de 20 minutos de imersão em peróxido (amostra T10_20) mostrou-se ineficiente para a proteção a corrosão, com valores de impedância inferiores aos valores da amostra de referência, durante todo o período analisado. Além de apresentar maior impedância em relação aos demais tratamentos, o tratamento T10_10 mostrou estabilização da superfície ao longo do período investigado. Quanto aos demais tratamentos, mostraram degradação das propriedades de proteção à corrosão com o tempo de ensaio.

Os resultados eletroquímicos comparativos, apresentados nas Figuras 40 e 41, permitem evidenciar que o tratamento por imersão da amostra T10 em peróxido de hidrogênio leva a melhora das propriedades anticorrosivas, para as amostras imersas por 1 e 10 minutos. Com base nestas observações que apoiaram os resultados de ensaios realizados em câmara de névoa salina o tratamento T10_10 foi selecionado como o de maior potencialidade para prosseguimento dos estudos e a evolução do seu comportamento eletroquímico foi avaliada em função do tempo de exposição ao meio corrosivo (solução 0,1 mol. $\mathrm{L}^{-1}$ de $\mathrm{NaCl}$ ) e os resultados são mostrados na Figura 43. 

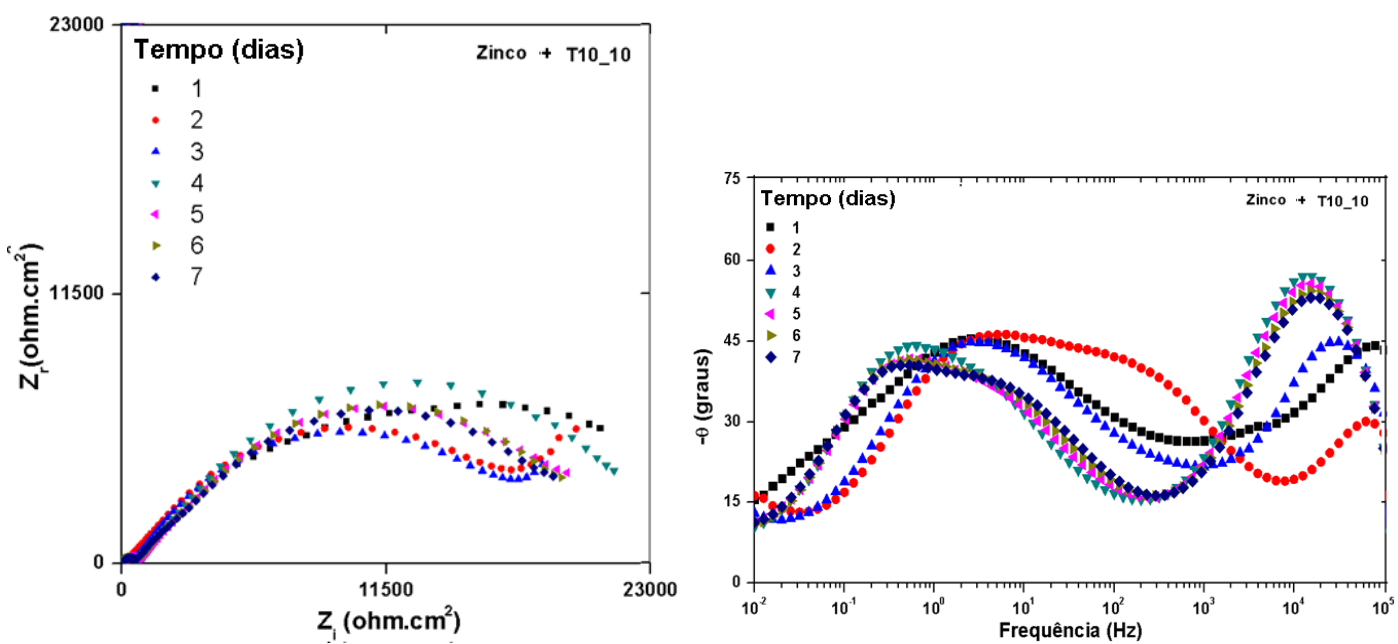

Figura 43: Diagramas de Nyquist e Bode ângulo de fase de 1 a 7 dias de imersão em solução $0,1 \mathrm{~mol} . \mathrm{L}^{-1}$ de $\mathrm{NaCl}$, da amostra com tratamento T10_10

A modificação do formato dos diagramas de impedância mostra uma evolução dos fenômenos interfaciais em função do tempo de imersão em solução eletrolítica. Os espectros EIE obtidos para a amostra T10_10 revelam a presença de três constantes de tempo. A primeira constante, em altas frequências, pode ser atribuída à presença da camada orgânica depositada na superfície e a segunda constante em frequências mais baixas, pode ser correlacionada com 0 aparecimento de produtos de corrosão.

Para o segundo dia de imersão é possível observar uma constante de tempo ampliada, que sugerindo a evolução para uma terceira constante que não se confirma nos dias seguintes. O comportamento a baixas frequências é resistivo, no entanto, a característica de constante temporal de aparecimento de corrosão não é definida. A corrosão é normalmente atribuída a um terceiro processo de relaxamento, que ocorre em baixa frequência, mas que não ocorreu.

Com o aumento do tempo de ensaio, as constantes de tempo em altas frequências são deslocadas para regiões de mais baixa frequência com valores de ângulo de fase maiores, estas são evidências de mecanismo de obstrução dos defeitos por deposição dos produtos de corrosão. Mesmo com a penetração do eletrólito no primeiro dia de imersão, estes se acumulam precipitando-se localmente nos defeitos do revestimento, causando aumento da resistência à 
corrosão ou a manutenção dos mesmos.

Os resultados apresentados mostram que a presença de íons cério na camada de conversão melhora as propriedades anticorrosivas quando aplicadas sobre aço eletrozincado. O mecanismo com que esta melhora ocorre pode estar relacionado com a precipitação de íons cério na forma de óxidos e hidróxidos nas regiões anódicas, reduzindo atividade catódica e consequentemente impedindo a transferência de elétrons entre os sítios anódicos e catódicos.

Os resultados indicam que mesmo havendo variação dos valores de impedância após sete dias, estes são praticamente os mesmos apresentados após dois dias de imersão, evidência de recuperação da propriedade anticorrosiva associada à melhora da propriedade barreira.

O tratamento T10_10 apresentou valores superiores de resistência à corrosão quando avaliado por espectroscopia de Impedância eletroquímica e por ensaio de corrosão acelerada em câmara de névoa salina. Os resultados se mostraram superiores ao revestimento de zinco sem tratamento de conversão e ao revestimento de cromato (CCC). Os defeitos mais pronunciados presentes na amostra T10 foram minimizados pelo tratamento de imersão em solução de peróxido de hidrogênio. Todos os tempos testados, pós tratamento T10, em peróxido de hidrogênio possibilitaram aumento dos valores de impedância e resistência à corrosão em câmara de névoa salina superiores a amostra T10, sem imersão em peróxido de hidrogênio. A resistência e a capacitância associada com a constante de tempo observado nos espectros de EIE foram determinados por ajuste numérico usando o circuito equivalente representado na Figura 44.

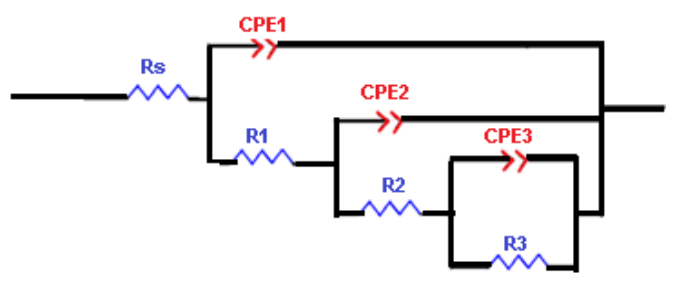

Figura 44: Circuito elétrico equivalente (CEE) utilizado nos ajustes dos dados de espectroscopia de impedância eletroquímica, arranjo com três constantes de tempo adotado para dados obtidos de 1 a 7 dias de imersão em $\mathrm{NaCl} 0,1$ mol..-1, para a amostra com tratamento T10_10. 
O circuito elétrico equivalente inclui uma resistência $R 1$, resistência que descreve a resposta de alta frequência, e uma associação paralela, simulação do processo de baixa frequência. Essa associação inclui uma resistência $\left(R_{3}\right)$ e um elemento de fase constante $\left(\mathrm{CPE}_{2}\right)$, que é uma capacitância não ideal. $\mathrm{O}$ circuito apresentou erros mínimos, menores que 10\% para cada elemento, configurando ajustes precisos dos resultados experimentais. Valores para elementos de circuito elétrico equivalente em função do tempo de imersão em 0,1 mol.L ${ }^{-1}$ de $\mathrm{NaCl}$, para amostra T10_10 são mostrados na Tabela 18.

Tabela 18: Valores para elementos de circuito elétrico equivalente em função do tempo de imersão em 0,1 mol.L ${ }^{-1}$ de $\mathrm{NaCl}$, para amostra T10_10.

\begin{tabular}{|c|c|c|c|c|c|c|c|c|}
\hline $\begin{array}{l}\text { Elementos do } \\
\text { circuito }\end{array}$ & $\begin{array}{l}\text { Tempo } \\
\text { (dias) }\end{array}$ & 1 & 2 & 3 & 4 & 5 & 6 & 7 \\
\hline 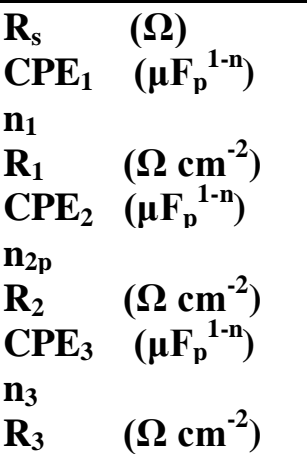 & & $\begin{array}{l}31,8 \\
127 \\
0,98 \\
21 \\
59 \\
0,4 \\
741,3 \\
34,8 \\
0,7 \\
29131\end{array}$ & $\begin{array}{l}60,6 \\
121 \\
0,95 \\
80,8 \\
44 \\
0,61 \\
657 \\
82 \\
0,9 \\
14167\end{array}$ & $\begin{array}{l}67,8 \\
448 \\
0,99 \\
215 \\
93,2 \\
0,57 \\
586,1 \\
51 \\
0,66 \\
19760\end{array}$ & $\begin{array}{l}56 \\
202 \\
1 \\
122,3 \\
45 \\
0,89 \\
754 \\
99 \\
0,65 \\
27358\end{array}$ & $\begin{array}{l}54,4 \\
107 \\
1 \\
180 \\
47 \\
0,82 \\
732,9 \\
101 \\
0,64 \\
28345\end{array}$ & $\begin{array}{l}54,5 \\
690 \\
0,99 \\
328,5 \\
45 \\
0,83 \\
595,7 \\
305 \\
0,63 \\
23553\end{array}$ & $\begin{array}{l}57,7 \\
630,8 \\
0,99 \\
470 \\
48 \\
0,89 \\
556,8 \\
640 \\
0,61 \\
23583\end{array}$ \\
\hline
\end{tabular}

Os valores obtidos para os ajustes dos dados experimentais confirmam a estabilização dos valores de impedância, indicados pelas resistências $R_{2 p}$ e $R_{3 c t}$ que, embora sofram alterações, ainda assim se mantêm em uma faixa estreita de valores, centenas de ohms $\left(\Omega / \mathrm{cm}^{2}\right)$ e $20 \mathrm{k} \Omega / \mathrm{cm}^{2}$, respectivamente. Estes valores de resistência permitem observar que o efeito protetivo se deve aos produtos de corrosão, uma vez que os valores de $R_{3 c f}$ são, para todos os dias analisados, maiores que os valores de $R_{2 p}$.

O presente estudo possibilitou a obtenção de respostas de questões elaboradas inicialmente quanto à adição de uma etapa de imersão em peróxido de hidrogênio da amostra com tratamento T10 (sal de cério + aditivo orgânico + nitrato + sulfato) sobre o aço eletrozincado, nos tempos testados: o filme formado tem morfologia modificada em função do tempo de imersão, com maior uniformidade e com número de defeitos reduzidos. Possibilita a deposição de 
cério em concentrações menores, comparativamente ao tratamento de imersão em solução de nitrato por 10 minutos, mas o cério depositado aparece na forma de seu óxido de maior estabilidade e, portanto, mais protetivo contra a corrosão.

Após o tratamento de imersão da amostra $\mathrm{T} 10$ em solução contendo peróxido de hidrogênio por 10 minutos, amostra T10_10 foi adotada para uma nova etapa ou tratamento. Estas amostras foram imersas em solução contendo oxalato de nióbio amoniacal, 2 butino 1,4diol propoxilato, nitrato de sódio e sulfato de sódio, como tentativa de incorporar nióbio na camada formada e, assim, incrementar a proteção à corrosão. 


\subsubsection{Efeito do tempo de imersão em solução de oxalato de nióbio amoniacal (ANO).}

Após tratamento em solução contendo cério, seguido de tratamento por imersão em solução de peróxido de hidrogênio, o presente trabalho teve sequência com a investigação do efeito do tempo de imersão (1, 10 e 20 minutos) em solução contendo oxalato de nióbio amoniacal com 2 butino 1,4 diol propoxilato, nitrato de sódio e sulfato de sódio, tratamentos T10_10_1, T10_10_10 e T10_10_20.

Esta etapa propõe investigar o papel do oxalato de nióbio amoniacal como pós-tratamento na proteção a corrosão de aço eletrozincado e a possibilidade de deposição de íons nióbio na camada formada. Segundo Scchonjahn e Ardelean (SCHONJAHN, 2001, ARDELEAN, 2008), camadas constituídas por óxidos de nióbio, depositados quimicamente por imersão em banhos de conversão, promovem boa resistência à corrosão. A eficiência na proteção à corrosão acredita-se ser causada pela presença do nióbio pentavalente, óxido de alta estabilidade. As seguintes questões devem ser respondidas nesta etapa:

\section{1) A adição de uma etapa de imersão em solução de oxalato de nióbio amoniacal modifica o filme formado no tratamento T10_10 (Cério+ Peróxido de hidrogênio) sobre o aço eletrozincado?}

\section{2) A imersão em oxalato de nióbio amoniacal causa deposição de nióbio no filme formado?}

Nas seções seguintes procurar-se-á responder a estas questões.

5.3.3.1. Morfologia (Microscopias de Emissão, Microscopia Óptica tridimensional) e Difração de raios $X$.

As micrografias obtidas por microscopia de emissão (FEG) para as os tratamentos T10_10 sem imersão em solução de nióbio (referência) e T10_10_1, imersão por 1 minuto em solução contendo nióbio, são apresentadas na Figura 45 A e $B$, respectivamente. 

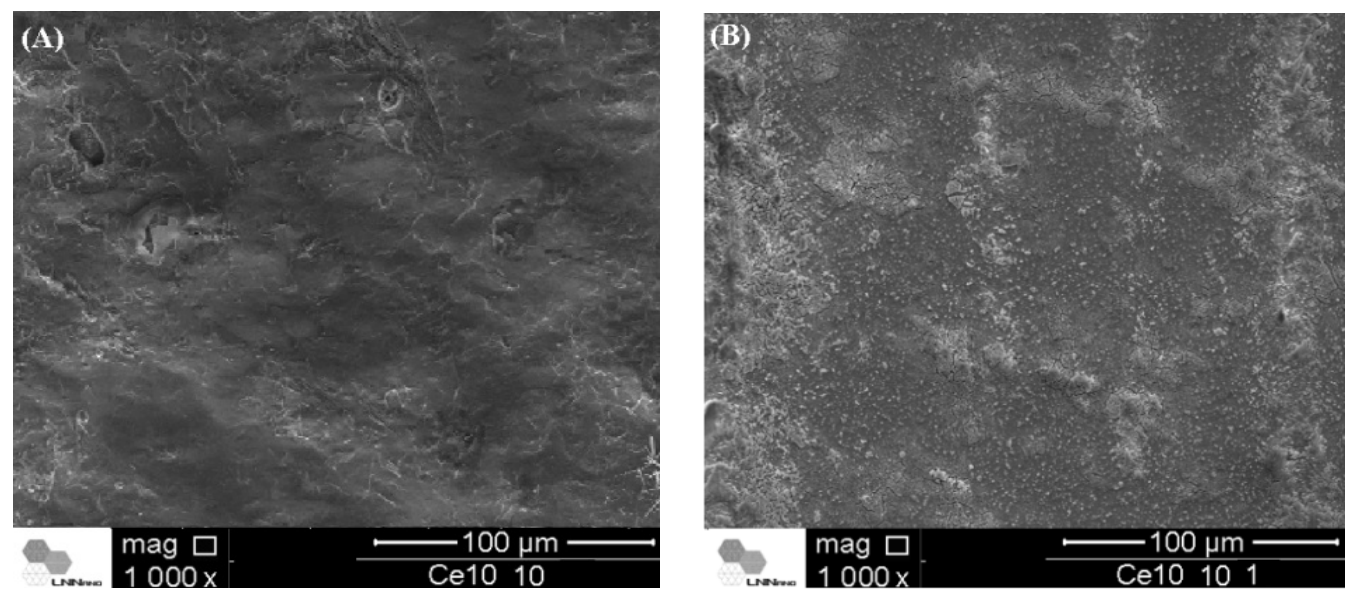

Figura 45: Micrografias obtidas por FEG para os tratamentos: (A) T10_10 (sem imersão em solução contendo nióbio); (B) T10_10_1, (T10_10 seguido por imersão por 1 minuto em solução contendo nióbio).

A micrografia da superfície com tratamento T10_10_1 apresenta superfície com defeitos em menor número e extensão comparativamente à superfície da amostra com tratamento T10_10. A etapa de imersão da amostra com o tratamento T10_10 por 1 minuto em solução contendo nióbio possibilita o recobrimento de defeitos, com a formação de camada mais homogênea. As micrografias obtidas por microscopia de emissão (FEG) para as amostras com tratamentos T10_10_10 e T10_10_20 são mostradas na Figura 46 A e B, respectivamente.
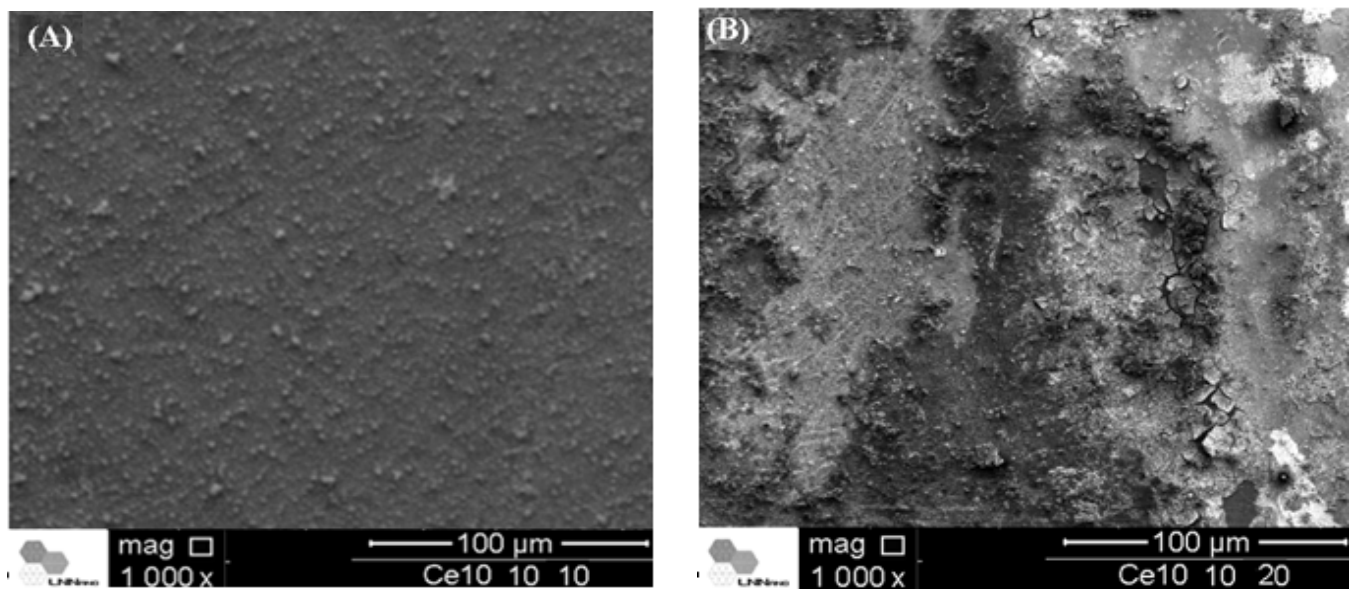

Figura 46: Micrografias obtidas por FEG $(1000 \mathrm{X})$ para as amostras com tratamentos: (A) T10_10_10 e (B) amostra T10_10_20. 
O tempo de imersão de 10 minutos da amostra em solução contendo nióbio (T10_10_10) leva à formação de filme aparentemente mais contínuo e homogêneo. A micrografia da superfície da amostra com tratamento T10_10_20 permite observar a formação de grande quantidade de defeitos na superfície, com o aparecimento de trincas e escamação do filme formado, mostrando que o tempo de 20 minutos de tratamento excedeu o tempo ótimo de tratamento nesta solução.

Esses resultados permitem concluir que a imersão em solução de oxalato de nióbio amoniacal com 2 butino 1,4 diol propoxilato, nitrato de sódio e sulfato de sódio, causa a formação de filme na superfície em tempos menores de imersão, mas um tempo ideal deve ser investigado para evitar a formação de uma camada defeituosa que expõe o substrato ao meio corrosivo.

Como forma de avaliar a uniformidade da superfície e o efeito do tratamento de imersão em solução contendo nióbio na morfologia da superfície, esta foi avaliada por Microscopia Ótica utilizando imagens tridimensionais. As imagens são apresentadas na Figura 47, para as superfícies com os tratamentos: (A) T10_10, (B) T10_10_1. (C) T10_10_10 e (D) T10_10_20.
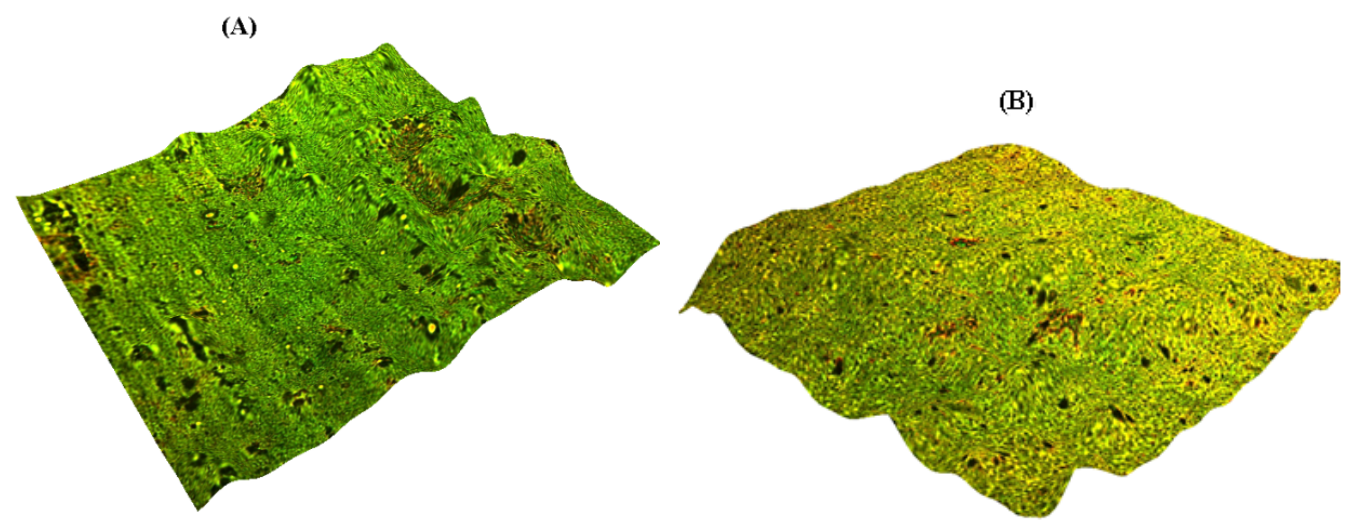

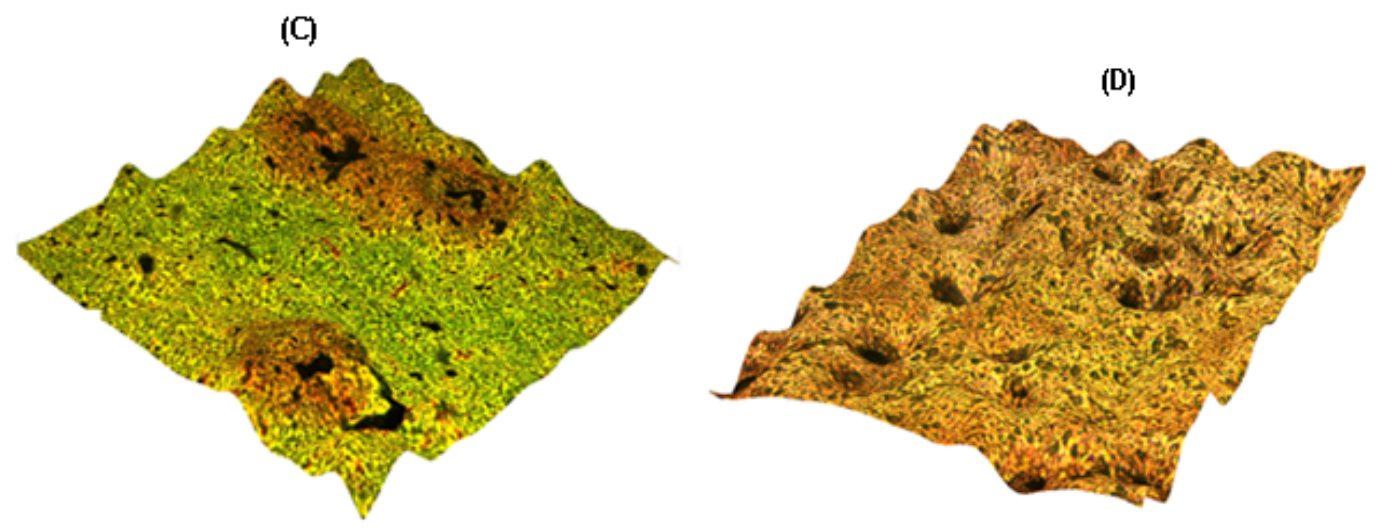

Figura 47. Micrografia ótica tridimensional das amostras com tratamentos: (A) T10_10, (B) T10_10_1, (C) T10_10_10 e (D) T10_10_20. (Aumento: 50X)

As imagens tridimensionais apresentadas na Figura 46 permitiram observar que a etapa de tratamento em solução contendo nióbio promove a formação de superfícies menos defeituosas para tempos reduzidos de imersão (1 minuto). As imagens sugerem que tempos maiores de imersão causam maior ataque superficial e consequentemente, superfícies mais irregulares.

5.3.3.2. Análise da composição química (Espectroscopia no Infravermelho por Transformada de Fourier e Espectroscopia Fotoeletrônica de Raios X).

A superfície das amostras com os tratamentos T10_10_1, T10_10_10 e T10_10_20 foi analisada por espectroscopia no infravermelho por transformada de Fourier (FTIR) e os espectros obtidos são mostrados na Figura 48. 


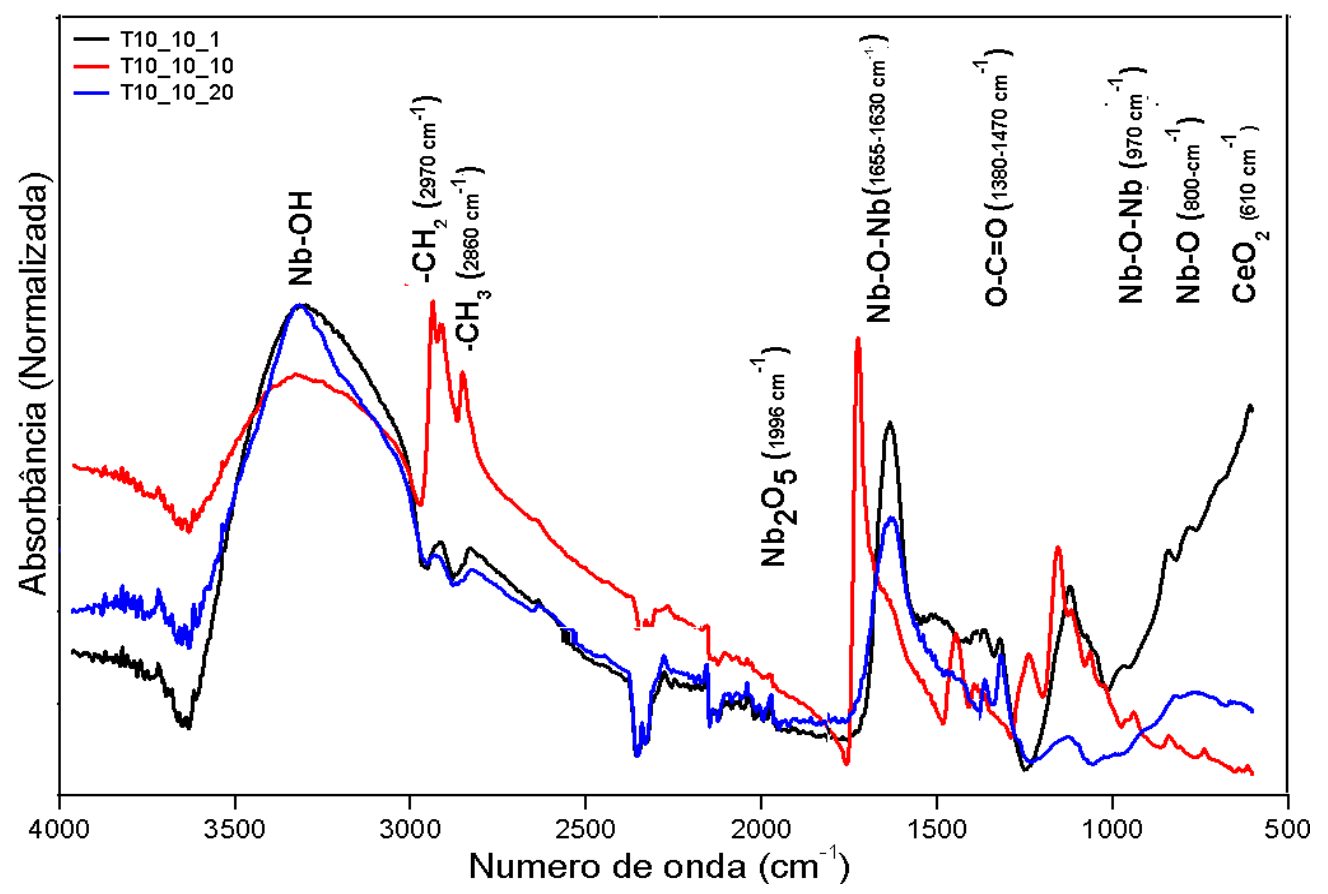

Figura 48: Espectros normalizados de FTIR da superfície das amostras com tratamentos T10_10_1, T10_10_10 e T10_10_20.

Os espectros vibracionais no infravermelho mostram bandas largas entre $3500 \mathrm{~cm}^{-1}$ e $3000 \mathrm{~cm}^{-1}$ correspondentes ao estiramento do grupo hidroxila (-OH), devido à presença de água adsorvida. O estreitamento nesta faixa, observado pelo pico da amostra tratada em solução com composto de nióbio, centrado em $3340 \mathrm{~cm}^{-1}$, corresponde ao estiramento $\mathrm{Nb}-\mathrm{OH}$. A presença deste tipo de ligação entre nióbio e o grupo hidroxila, pode ser observada também pelas bandas de absorção entre $1700 \mathrm{~cm}^{-1}$ e $1500 \mathrm{~cm}^{-1}$, referentes à deformação angular desta ligação (SCHMITT, 2009).

Os picos nas regiões entre $950 \mathrm{~cm}^{-1}$ e $840 \mathrm{~cm}^{-1}$ e $700 \mathrm{~cm}^{-1}$ e $600 \mathrm{~cm}^{-1}$ correspondem, respectivamente, ao estiramento da ligação $\mathrm{Nb}=\mathrm{O}$ e $\mathrm{Nb}-\mathrm{O}-\mathrm{Nb}$ (HUANG, 1999, 1999). Picos específicos observados em $1085 \mathrm{~cm}^{-1}$ e $1125 \mathrm{~cm}^{-1}$ foram relatados como diferentes estiramentos das ligações $\mathrm{Nb}-\mathrm{O}$ do composto $\mathrm{Nb}_{2} \mathrm{O}_{5}$ quando em presença de ácido nítrico (BRANDÃO, 2009). Quando comparados os espectros acima com os obtidos para as amostras com tratamento T10_10 (Figura 37), observa-se dois picos entre $1300 \mathrm{~cm}^{-1}$ e $1700 \mathrm{~cm}^{-}$ ${ }^{1}$, referentes à presença de nióbio como óxido pentavalente. 
Para todos os espectros apresentados, houve correspondência quanto aos picos ou bandas de absorbância consideradas como principais. Foram observadas bandas de absorção, aproximadamente em $610 \mathrm{~cm}^{-1}, 800 \mathrm{~cm}^{-1}, 873$ $\mathrm{cm}^{-1}, 970 \mathrm{~cm}^{-1}, 1117 \mathrm{~cm}^{-1}, 1317 \mathrm{~cm}^{-1}, 1363 \mathrm{~cm}^{-1}, 1630 \mathrm{~cm}^{-1}, 1996 \mathrm{~cm}^{-1}, 1975 \mathrm{~cm}^{-1}$, $2054 \mathrm{~cm}^{-1}, 2164 \mathrm{~cm}^{-1}, 2289 \mathrm{~cm}^{-1}, 2654 \mathrm{~cm}^{-1}, 2860 \mathrm{~cm}^{-1}, 2970 \mathrm{~cm}^{-1}, 3327 \mathrm{~cm}^{-1}$.

Os filmes formados após o tratamento de imersão em solução contendo nióbio apresentam constituição química semelhante aos obtidos por tratamento de imersão por 10 minutos em solução contendo cério (T10), e ao tratamento T10 seguido por imersão por 10 minutos em solução de peróxido de hidrogênio (T10_10). A diferença nos espectros entre estes e os das superfícies das amostras T10_10_1, T10_10_10 e T10_10_20 fica restrito às bandas de absorbância pertencentes aos estiramentos de nióbio.

A observação destes picos, em grande parte semelhantes ou com número de ondas próximos, permite afirmar que o tratamento por imersão em solução contendo composto orgânico e nióbio praticamente não altera a constituição química da camada formada, com exceção da incorporação de nióbio na camada.

Bandas de absorção representadas por picos localizados em $610 \mathrm{~cm}^{-1} \mathrm{e}$ $2842 \mathrm{~cm}^{-1}$, relacionados ao elemento cério na forma de óxido e de nitrato de cério III, respectivamente, permitem observar que há uma diminuição dos sinais, e que, portanto, embora haja cério, não há evidências de diminuição na concentração, comparativamente à superfície das amostras T10 e T10_10. Esta diminuição do sinal pode ter sido causada pela espessura maior ficando o cério localizado mais internamente na camada formada.

As espécies orgânicas presentes no filme formado são representadas pelos picos aproximados com bandas de absorção em $2860 \mathrm{~cm}^{-1}$ e $2970 \mathrm{~cm}^{-1}$ correspondentes, respectivamente, ao grupo metil $\left(-\mathrm{CH}_{3}\right)$ e carbono secundário $\left(\mathrm{CH}_{2^{-}}\right)$, e em $2120 \mathrm{~cm}^{-1}$, correspondente ao grupo carboxil $(\mathrm{H}-\mathrm{C}=\mathrm{O})$. Partes da molécula do precursor polimérico ou de outra estrutura orgânica, originária do mesmo, foram incorporadas na superfície (SHAO, 2012). A observação destes picos ou bandas de absorção ocorre apenas para a amostra com tratamento T10_10_10 e é evidência de que o filme orgânico é formado mais efetivamente 
nesta amostra do que nas amostras com tratamento de imersão em solução contendo nióbio, por 1 e 20 minutos, tratamentos T10_10_1 e T10_10_20, respectivamente.

Os picos presentes entre $1630 \mathrm{~cm}^{-1}$ e $1655 \mathrm{~cm}^{-1}$, reportados como estiramentos das ligações entre nióbio e oxigênio, são maiores para a amostra com tratamento T10_10_10, mostrando que o tempo de imersão por 10 minutos é mais efetivo na deposição de nióbio e que esta ocorre com nióbio depositado na forma de óxido.

Análises por espectroscopia fotoeletrônica de raios $X$ (XPS) foram realizadas como forma de obter resultados, qualitativos e quantitativos, mais precisos sobre a composição química das camadas formadas. Espectros de XPS foram obtidos para os tratamentos T10_10_1, T10_10_10 e T10-10_20 e são mostrados na Figura 49. Os elementos presentes na camada formada foram identificados.

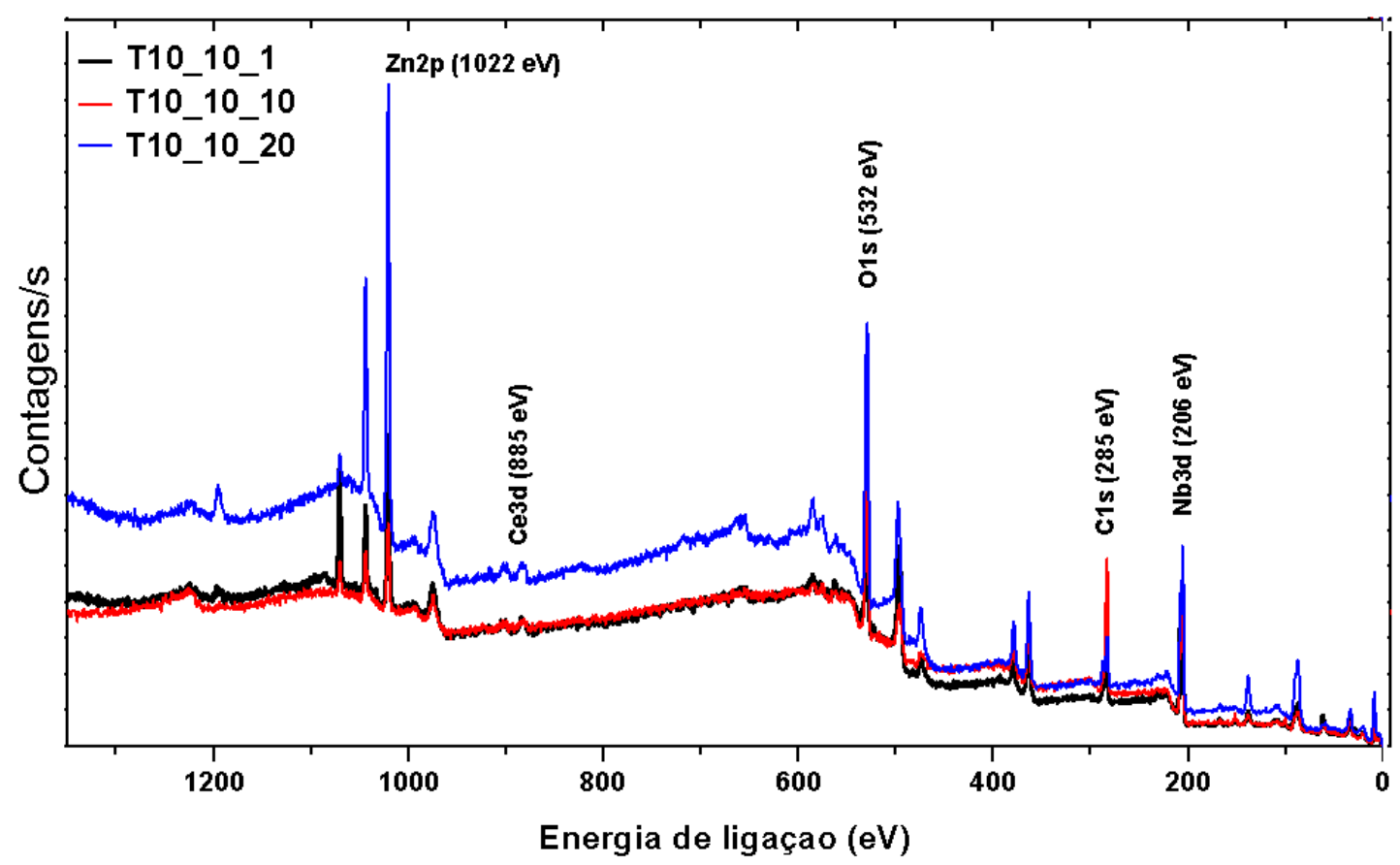

Figura 49: Espectro geral obtido por espectroscopia fotoeletrônica de raios $X$ (XPS) da superfície de aço eletrozincado com os tratamentos T10_10_1, T10_10_10 e T10_10_20. 
O espectro geral obtido por XPS permite observar a presença dos elementos carbono (C1s, $285 \mathrm{eV})$ proveniente do filme orgânico formado, oxigênio (O 1s, 532 eV), zinco (Zn2p, 1022 eV), cério (Ce3d, 885 eV) e nióbio (Nb, 207 eV), além de picos Auger não referenciados.

Os elementos identificados foram os mesmos observados para as amostras com o tratamento T10_10, exceção para o elemento nióbio. Pode-se, portanto, afirmar que o tratamento de imersão em solução contendo oxalato de nióbio amoniacal, 2 butino 1,4-diol propoxilato, nitrato e sulfato de sódio foi eficiente na deposição de nióbio na camada formada. Os espectros iniciais fornecem as condições para obtenção de espectros de maior resolução (maior número de varreduras) para todas as espécies observadas. Os picos, energias de ligação, fator de ajuste (FWHM) e concentrações atômicas por elementos obtidos dos espectros XPS são mostrados na Tabela 19.

Tabela 19: Picos, energias de ligação, fator de ajuste (FWHM) e concentrações atômicas, obtidos por XPS, das amostras com os tratamentos T10_10_1, T10_10_10 e T10_10_20.

\begin{tabular}{|c|c|c|c|c|c|}
\hline & \multicolumn{3}{|c|}{ AMOSTRAS } \\
\hline & & & T10_10_1 & T10_10_10 & T10-10-20 \\
\hline PICOS & E.L (eV) & F.W.H.M & \multicolumn{3}{|c|}{$\begin{array}{c}\text { at } \% \\
\text { Porcentacem en massa }\end{array}$} \\
\hline C1s & 285 & 1,80 & 24,0 & 29,2 & 31,0 \\
\hline 01s & 532 & 2,20 & 50,0 & 48,2 & 48,1 \\
\hline $\mathrm{Zn} 2 \mathrm{p} 3$ & 1022 & 2,20 & 14,3 & 11,0 & 6,15 \\
\hline Ce3d & 886 & 2,10 & 1,21 & 1,21 & 1,21 \\
\hline Nb3d & 207 & 1,6 & 10,5 & 10,4 & 13,6 \\
\hline
\end{tabular}

Os resultados obtidos pelos espectros de alta resolução permitiram a estimativa da concentração de carbono. O teor de carbono aumenta em função do tempo de imersão em solução contendo nióbio, pois esta etapa do tratamento também contém 2 butino 1,4 diol propoxilato, isto é, um composto orgânico que resulta na formação de um filme orgânico superficial. Comparativamente aos resultados apresentados para amostras com tratamento T10_10, a etapa 3 ou tratamento por imersão em solução contendo nióbio, levou valores intermediários para a concentração deste elemento. 
A concentração de carbono para a amostra com tratamento T10 é de $34,6 \%$, diminui para $16,1 \%$ quando este tratamento é seguido por imersão em solução de peróxido de hidrogênio (T10_10) e aumenta novamente para 29,2\% quando esta é seguida por imersão em solução contendo nióbio. A terceira etapa do tratamento resulta em concentração de carbono próxima à do tratamento da etapa 1 (imersão em solução com cério), devido a ambos os tratamentos conterem composto orgânico (2 butino 1,4 diol propoxilato).

Mesmo com a possível presença de carbonos adventícios ou contaminantes, como aumento na quantidade de etapas, há uma melhora na homogeneidade e diminuição de defeitos, provavelmente devido à densificação das camadas formadas com os tratamentos sucessivos realizados.

Com relação ao elemento cério, para o tratamento inicial (T10), a maior concentração de cério observada foi de 7,08\%. Quando este tratamento foi seguido por imersão por 10 minutos em solução de peróxido de hidrogênio, a concentração diminuiu para $2,95 \%$ e foi ainda mais reduzido $(1,2 \%)$ quando se realizou a terceira etapa, que consistiu na imersão em solução contendo nióbio por diferentes tempos. O tratamento T10_10_10, portanto, se mostrou eficiente na deposição de nióbio.

A presença de espécies contaminantes pode comprometer os resultados da análise de XPS quanto à composição real do filme. Para eliminar espécies superficiais contaminantes, foi realizado desbaste da superfície (sputtering) para aquisição de perfil de profundidade. Por meio deste processo, espécies fracamente adsorvidas são removidas por íons argônio. Novos espectros foram obtidos em diferentes níveis de profundidade, em função do tempo de sputtering.

$\mathrm{Na}$ Figura 50 são apresentados espectros obtidos por XPS para os elementos C1s, O1s, Zn2p, Ce3d e Nb3d em função do tempo de sputtering (segundos) da superfície do aço eletrozincado após tratamento T10_10_10, obtendo-se o perfil de profundidade em função do tempo de sputtering. 


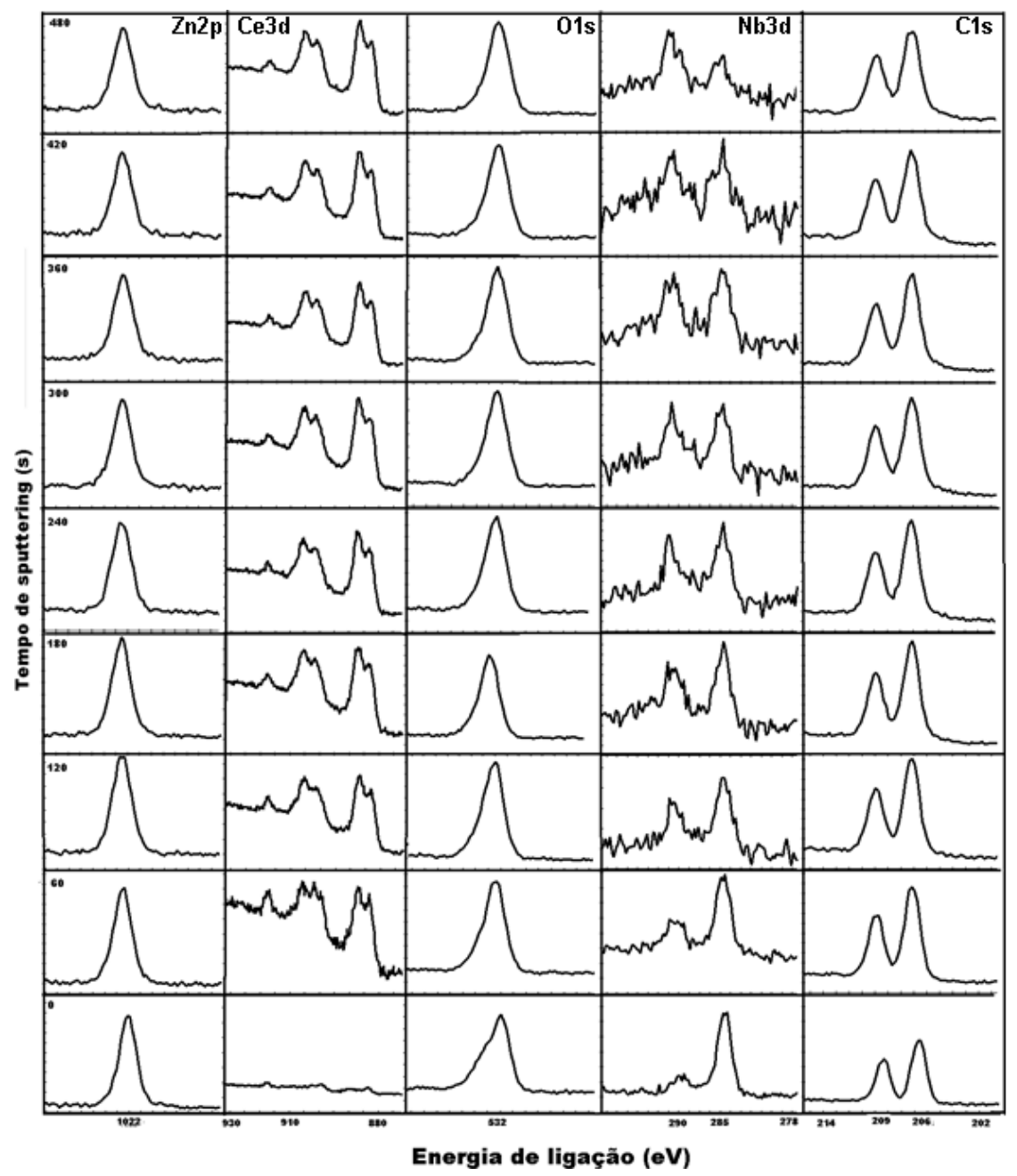

Figura 50: Espectros XPS para os elementos C1s, O1s, Zn2p, Ce3d e Nb3d obtidos em função do tempo de sputtering (em segundos) da superfície do aço eletrozincado após tratamento T10_10_10.

Os espectros permitem observar, para o carbono $\mathrm{C} 1 \mathrm{~s}$, dois picos posicionados em $285 \mathrm{eV}$ e $290 \mathrm{eV}$. Os picos em $285 \mathrm{eV}$ são associados às ligações $\mathrm{C}-\mathrm{C}$ e $\mathrm{C}-\mathrm{H}$. Estes, quando presentes na forma de compostos contaminantes adsorvidos, são removidos em tempos reduzidos de sputtering.

A permanência deste carbono é justificada como sendo pertencente às ligações $\mathrm{C}-\mathrm{C}$ e $\mathrm{C}-\mathrm{H}$ dos ácidos carboxílicos ligados ao substrato por ligações fortes, ligações covalentes e, portanto, de difícil remoção. As concentrações atômicas, picos, energias de ligação e fatores de ajuste para o elemento carbono, obtidas por XPS em função do tempo de sputtering em segundos (s), para as amostras com tratamento T10_10_10, são apresentadas na Tabela 20. 
Tabela 20: Concentrações atômicas e fatores de ajuste para C1s, obtidas por XPS em função do tempo etch (sputtering) em s, para o tratamento T10_10_10.

\begin{tabular}{lccccc}
\hline $\begin{array}{l}\text { Tempo etch (s) } \\
\text { C1s (fitting) }\end{array}$ & 0 & 60 & 240 & 300 & 480 \\
TRAT. T10_10 & \multicolumn{5}{c}{$\begin{array}{c}\text { at\% } \\
\text { porcentagem em massa }\end{array}$} \\
\cline { 2 - 6 } C-C/C-H & 79,0 & 69,2 & 45,6 & 38,1 & 37,5 \\
C-O/C-OH & 3,60 & 1,30 & 3,70 & 3,68 & 2,4 \\
C=O & 9,83 & 2,40 & 11,7 & 34,1 & 1,5 \\
O-C=O & 7,67 & 27,1 & 39,0 & 22,7 & 59,5 \\
\hline
\end{tabular}

Os resultados para as diferentes formas de ligação do carbono ao longo da camada, em função da profundidade, mostram que estes podem ser representados por $\mathrm{C}-\mathrm{C} / \mathrm{C}-\mathrm{H}$ associados a carbonos alifáticos de espécies fracamente adsorvidas, ou de parte da cadeia carbônica do filme orgânico depositado. As ligações $\mathrm{C}-\mathrm{O} / \mathrm{C}-\mathrm{OH}, \mathrm{C}=\mathrm{O}$ e $\mathrm{O}-\mathrm{C}=\mathrm{O}$ são todas relacionadas à parte das cadeias carbônicas do filme, mais especificamente de ácido carboxílico (propanóico ou but-2-enóico).

Há uma grande variação da concentração destas formas químicas. No entanto, ao se observar a concentração em função do tempo de sputtering, de 0 até 480 segundos, observa-se tendência de aumento na concentração das ligações do grupo carboxil, $\mathrm{O}-\mathrm{C}=\mathrm{O}$. O único tempo em que ocorreu diminuição na concentração deste foi para 300 segundos, quando este foi compensado pelo aumento na concentração da ligação $\mathrm{C}=\mathrm{O}$. $\mathrm{O}$ aumento da concentração do grupo carboxil mais internamente na camada reforça a hipótese de formação de filme orgânico representado por ácido propanóico ou ácido but-2enóico, conforme proposto nas vias reacionais, Figura 13.

O carbono $\mathrm{C}-\mathrm{C} / \mathrm{C}-\mathrm{H}$ sofre redução durante todos os tempos de sputtering mostrados. No entanto, a sua presença contínua ao longo da camada permite concluir que este não se deve a espécie contaminante, podendo ser relacionado a ligantes de parte dos ácidos carboxílicos de que é constituído o filme. A presença deste, mesmo depois de 480 segundos de sputtering, mostra que estas ligações coexistem com maior quantidade de grupos carboxil. Portanto, podem fazer parte do ácido carboxílico ligado ao substrato. Concentrações atômicas, picos, energias de ligação e fatores de ajuste para elemento oxigênio, obtidas por XPS em função 
do tempo de sputtering (s), para as amostras com tratamento T10_10, 10, são apresentadas na Tabela 21.

Tabela 21: Concentrações atômicas e fatores de ajuste para 01s, obtidas por XPS em função do tempo de sputtering (s), para o tratamento T10_10_10.

\begin{tabular}{lccccc}
\hline $\begin{array}{l}\text { Tempo etch (s) } \\
\text { O1s (fitting) }\end{array}$ & 0 & 60 & 240 & 300 & 480 \\
TRAT. T10_10 & \multicolumn{5}{c}{$\begin{array}{c}\text { at\% } \\
\text { porcentagem em massa }\end{array}$} \\
\cline { 2 - 6 } $\mathrm{O}^{2-}$ & 35,5 & 16,2 & 12,6 & 33,2 & 78,5 \\
$\mathrm{OH}^{-}$ & 44,1 & 81,4 & 85,8 & 66,4 & 12,2 \\
$\mathrm{H}_{2} \mathrm{O}$ & 20,4 & 2,40 & 1,60 & 0,40 & 9,30
\end{tabular}

Os resultados para o ajuste do pico O1s mostram a presença de oxigênio na camada formada em três formas diferentes, óxido, hidróxido e água de adsorção. A presença de oxigênio referente à água de adsorção pode ocorrer tanto pela formação de complexos hidratados de cério, zinco e/ou de nióbio. Estes complexos são formados nos estágios iniciais de oxidação do zinco e, em estágios posteriores, causam a formação de óxidos.

A presença de oxigênio na forma de óxido é predominante nos tempos de sputtering mais elevados, mostrando que o tratamento de imersão em solução contendo nióbio promove a formação de óxidos mais internamente na camada.

A quantidade elevada de oxigênio na forma de óxido pode ser justificada pela presença não só de óxido de zinco, mas também de cério e de nióbio. As concentrações de hidróxidos, embora quase exclusivamente atribuídos a $\mathrm{Zn}(\mathrm{OH})_{2}$, também são relacionadas com óxidos de nióbio para tempos iniciais de sputtering, muito provavelmente na forma de espécies transientes entre os estados de oxidação IV e V dos óxidos de nióbio. As concentrações atômicas, picos e energias de ligação para o elemento zinco obtidas por XPS da superfície da amostra com tratamento T10_10_10 são mostrados na Tabela 22. 
Tabela 22: Concentrações atômicas e fatores de ajuste para Zn2p, obtidas por XPS em função do tempo de sputtering (s) para o tratamento T10_10_10.

\begin{tabular}{lccccc}
\hline $\begin{array}{l}\text { Tempo etch (s) } \\
\text { Zn2p (fitting) }\end{array}$ & 0 & 60 & 240 & 300 & 480 \\
TRAT. T10_10 & \multicolumn{5}{c}{$\begin{array}{c}\text { at\% } \\
\text { porcentagem em massa }\end{array}$} \\
\cline { 2 - 6 } Zn (Metal) & 1,31 & 6,85 & 6,65 & 2,44 & 1,90 \\
ZnO & 95,5 & 85,0 & 30,4 & 96,0 & 95,2 \\
Zn(OH) 2 & 3,13 & 8,07 & 62,9 & 1,56 & 2,89 \\
\hline
\end{tabular}

Os resultados do ajuste para o pico de zinco mostram a presença de energias de ligações correspondentes a três diferentes formas, zinco metálico, óxido e hidróxido. As variações nas concentrações destas formas químicas ocorrem em toda a extensão da camada formada, contudo a concentração de óxido de zinco é a maior dentre as espécies observadas.

A camada formada pode ser descrita como tendo óxidos de zinco em toda a sua extensão, mas também hidróxidos, o que permite defini-la como camada mista. Esta camada pode ser definida como mista não só quanto às diferentes formas químicas do zinco presentes, originados pela solubilização do substrato eletrozincado, mas também pela presença de óxidos de cério e nióbio. As concentrações atômicas, picos, energias de ligação e fatores de ajuste para o cério, obtidas por XPS em função do tempo de sputtering (s), para as amostras com tratamento T10_10_10, são mostrados na Tabela 23.

Tabela 23: Concentrações atômicas e fatores de ajuste para Ce3d, obtidas por XPS em função do tempo de sputtering (s), amostra com tratamento T10_10_10.

\begin{tabular}{lccccc}
\hline $\begin{array}{l}\text { Tempo etch (s) } \\
\text { Ce3d (fitting) }\end{array}$ & 0 & 60 & 240 & 300 & 480 \\
TRAT. T10_10 & \multicolumn{5}{c}{$\begin{array}{c}\text { at\% } \\
\text { porcentagem em massa }\end{array}$} \\
\cline { 2 - 6 } Ce III & 48,2 & 41,3 & 51,1 & 67,7 & 65,0 \\
Ce IV & 51,8 & 58,7 & 48,9 & 32,3 & 35,0 \\
\hline
\end{tabular}

Os resultados obtidos por XPS após ajuste permitiram observar a presença de cério em dois estados de oxidação, em faixa de energia de ligação entre 880 
eV e $920 \mathrm{eV}$. As análises com até 480 segundos de sputtering permitiram observar picos centrados $919 \mathrm{eV}$, indicando a presença de $\mathrm{Ce}^{4+}$ na forma de óxido tetravalente $\left(\mathrm{CeO}_{2}\right)$.

Pode-se afirmar que houve formação de um filme orgânico e na superfície há óxidos de cério III e IV $\left(\mathrm{Ce}_{2} \mathrm{O}_{3}\right.$ e $\left.\mathrm{CeO}_{2}\right)$, provavelmente incorporados na camada formada. A quantidade destes óxidos varia com a profundidade em direção ao substrato de zinco com o tempo de sputtering, predomina $\circ \mathrm{CeO}_{2}$ até 60 segundos. Quanto mais no interior da camada formada, maior a quantidade de óxido de cério trivalente $\left(\mathrm{Ce}_{2} \mathrm{O}_{3}\right)$. Portanto, pode-se concluir que o pós-tratamento por imersão em solução contendo composto de nióbio amoniacal (ANO) muda os estados de oxidação dos óxidos de cério.

$\mathrm{Na}$ etapa anterior, tratamento por imersão em solução de peróxido de hidrogênio, a presença de cério IV em maior quantidade foi observada depois de $300 \mathrm{~s}$ de sputtering. Aramaki (ARAMAKI, 2002) afirma que o cério na forma de óxido tetravalente, por ser menos solúvel que a forma trivalente, precipita em regiões de corrosão, o que poderia resultar em um mecanismo ainda questionável de autocura.

A presença de cério e sua continuidade com o aumento no tempo de sputtering sugerem que o cério está distribuído em toda a profundidade da camada formada e, fortemente ligado (ligação covalente) a oxigênio de sítios do substrato de óxido de zinco. Todavia, não há evidências de cério ligado a componentes orgânicos. As concentrações atômicas, picos, energias de ligação e fatores de ajuste para o nióbio, obtidas por XPS em função do tempo de sputtering (s), para a superfície com tratamento o T10_10_10, são mostrados na Tabela 24. 
Tabela 24: Concentrações atômicas e fatores de ajuste para Nb3d, obtidos por XPS em função do tempo de sputtering (s) para o tratamento T10_10_10.

\begin{tabular}{lccccc}
\hline $\begin{array}{l}\text { Tempo etch (s) } \\
\text { Nb3d (fitting) }\end{array}$ & 0 & 60 & 240 & 300 & 480 \\
TRAT. T10_10 & \multicolumn{5}{c}{$\begin{array}{c}\text { at\% } \\
\text { porcentagem em massa }\end{array}$} \\
\cline { 2 - 6 } & 34,9 & 16,5 & 4,60 & 0,94 & 2,90 \\
$\mathrm{NbO}_{2}$ & 65,1 & 83,5 & 95,4 & 99,6 & 97,1
\end{tabular}

Os resultados dos ajustes mostram que as variações nas concentrações dos óxidos de nióbio $\left(\mathrm{NbO}_{2}, \mathrm{Nb}_{2} \mathrm{O}_{5}\right)$ ocorrem em toda a extensão da camada formada, e a concentração de nióbio para óxido pentavalente é maior em praticamente toda a extensão da amostra analisada.

Ferreira Jr (FERREIRA JR, 2012), relata que a deposição de nióbio por imersão em soluções de oxalato de nióbio amoniacal depende do controle de $\mathrm{pH}$ e pode ser limitado pela quantidade de espécies químicas competitivas no tratamento. Todavia, as concentrações determinadas por XPS dificilmente são maiores que $10 \%$.

5.3.3.3. Resultados eletroquímicos (Ensaios de corrosão acelerada e Espectroscopia de Impedância Eletroquímica).

Os resultados obtidos em câmara de névoa salina são apresentados na Tabela 25, indicando os tempos observados para aparecimento de corrosão branca, início da corrosão vermelha, recobrimento de $10 \%$ da superfície com produtos de corrosão vermelha para superfícies sem tratamentos e com os tratamentos T10_10_1, T10_10_10 e T10_10_20. Superfícies com camadas de conversão à base de cromo hexavalente foram também testadas para efeito de comparação. 
Tabela 25: Tempos para aparecimento de produtos de corrosão na superfície de amostras com camada de conversão de cromatos e com os tratamentos investigados, T10_10_1, T10_10_10 e T10_10_20.

\begin{tabular}{lccc}
\hline & \multicolumn{3}{c}{ Tempo (h) - Aparecimento de corrosão } \\
\cline { 2 - 4 } Tratamentos & $\begin{array}{c}\text { Corrosão } \\
\text { branca }\end{array}$ & $\begin{array}{c}\text { Corrosão } \\
\text { vermelha }\end{array}$ & $\begin{array}{c}\text { Corrosão } \\
\text { vermelha } \\
10 \%\end{array}$ \\
\hline Zinco & 8 & 75 & 80 \\
Zinco + CCC & 96 & 240 & 250 \\
Zinco + T10 & 120 & 336 & 400 \\
Zinco+ T10_10 & 144 & 290 & 380 \\
Zinco + T10_10_1 & 110 & 192 & 218 \\
Zinco+ T10_10_10 & 144 & 384 & 432 \\
Zinco+ T10_10_20 & 168 & 200 & 216 \\
\hline
\end{tabular}

A comparação dos tempos correspondentes a formação de produtos de corrosão, entre as amostras com tratamento T10_10_10 e com camada de conversão de cromato mostram a efetiva contribuição deste tratamento na resistência à corrosão do eletrozincado. Os maiores tempos para a formação de corrosão branca nas amostras com os tratamentos propostos, em comparação ao tratamento com cromato, mostram que os tratamentos propostos retardam a corrosão do substrato.

A comparação entre os tempos para a formação de produtos de corrosão de cor vermelha para os diferentes tratamentos testados mostra que o aumento do tempo de imersão em solução contendo nióbio amoniacal (ANO) com composto orgânico, de 1 para 10 e de 10 para 20 minutos, retarda os processos de corrosão do revestimento de zinco. Porém, a proteção oferecida pelo produto de corrosão do zinco, retardando o aparecimento de produtos de corrosão vermelha, foi maior para o tempo de tratamento de 10 minutos em comparação a 1 e 20 minutos de tratamento.

Este resultado sugere que a presença de defeitos no filme formado por 20 minutos de tratamento em solução com ANO ocorre em grande proporção e extensão, sendo difícil aos produtos de corrosão branca proporcionar proteção duradoura ao substrato metálico. Este resultado já tinha sido indicado pela observação da superfície microscopicamente. 
Os resultados de espectroscopia de impedância eletroquímica serão apresentados na forma de diagramas de Nyquist e de ângulo de fase de Bode, para os tratamentos que incluíram a etapa 3 , ou seja, imersão em solução contendo oxalato de nióbio amoniacal. A comparação dos resultados de impedância eletroquímica para 1 e 5 dias de imersão, das amostras de aço eletrozincados com os tratamentos T10_10, T10_10_1, T10_10_10 e T10_10_20 é mostrada na Figura 51, por meio de diagramas de Nyquist.
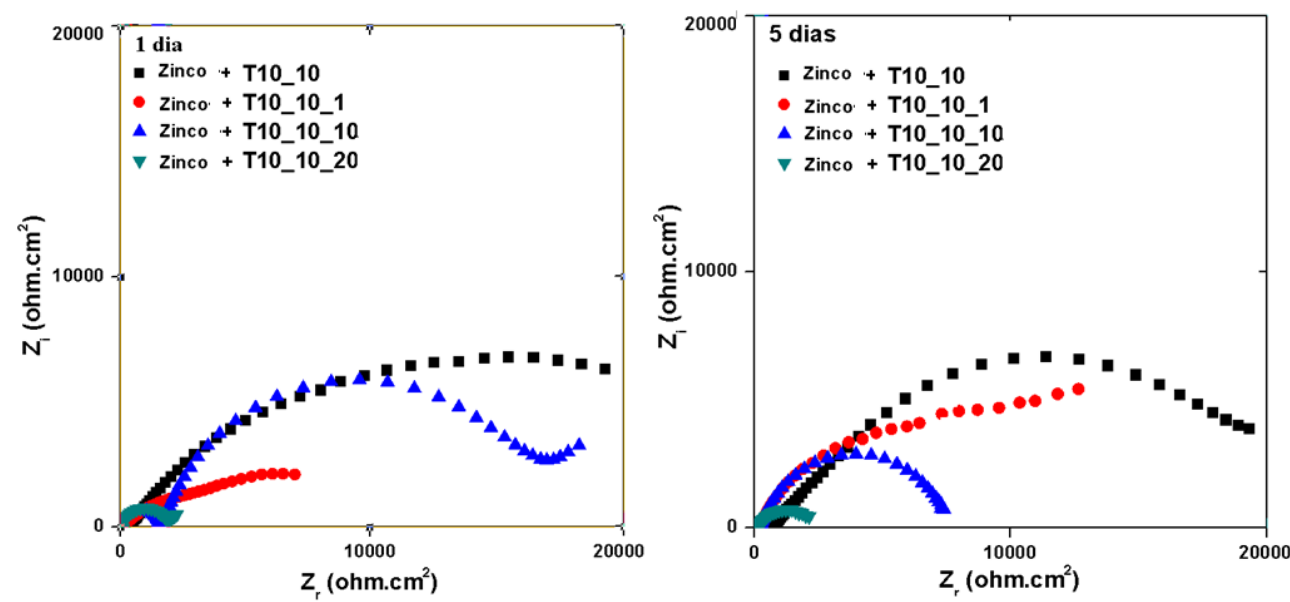

Figura 51: Diagramas de Nyquist para 1 e 5 dias em solução $0,1 \mathrm{~mol} \mathrm{~L}^{-1}$ de $\mathrm{NaCl}$, de amostras com tratamentos T10_10, T10_10_1, T10_10_10 e T10_10_20.

O tratamento usado como referência, T10_10, apresentou valores de impedância superiores aos tratamentos com diferentes tempos de imersão em solução contendo nióbio, amostras T10_10_1, T10_10_10 e T10_10_20, para tempos de imersão de 1 e 5 dias de imersão no meio corrosivo. Os tratamentos que incluíram imersão por 1 e 10 minutos em solução contendo nióbio. Amostras com tratamentos T10_10_1 e T10_10_10, embora no primeiro dia de imersão tenham apresentado valores de impedância menores que os da amostra de referência, após o quinto dia de imersão, apresentaram aumento de impedância.

A evolução da impedância eletroquímica de amostras de aço eletrozincado com os tratamentos T10_10, T10_10_1, T10_10_10 e T10_10_20, de 7 dias de imersão, para 9 dias e deste para 11 dias, são mostrados na Figura 52, pelos diagramas de Nyquist. 

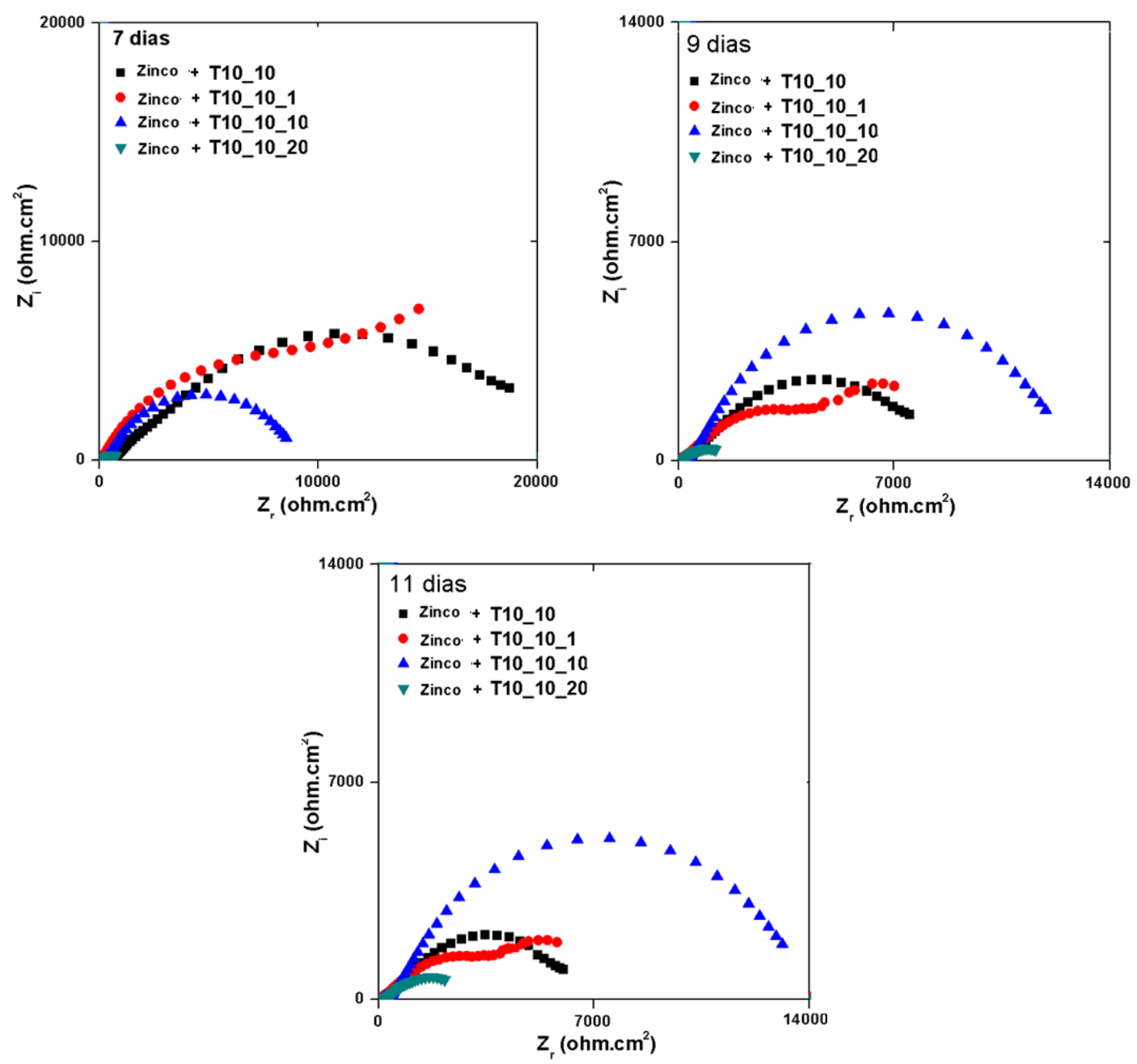

Figura 52: Diagramas de Nyquist para amostra com o tratamento T10_10_10 em 7,9 e 11 dias de imersão em solução $0,1 \mathrm{~mol}^{-L^{-1}}$ de $\mathrm{NaCl}$.

Os resultados de impedância eletroquímica para 5 e 7 dias de imersão, mostrados na forma de diagramas de Nyquist para as amostras T10_10_1, T10_10_10 e T10_10_20, sugerem que os processos de interação entre as amostras são dinâmicos, com mudança na cinética de corrosão indicada por mudança nas formas das curvas de impedância.

Os resultados eletroquímicos representados nos diagramas de Nyquist para 1, 5, 7, 9 e 11 dias para o tratamento T10_10 mostram redução significativa dos valores de impedância a partir do nono dia. Todavia, para o tratamento T10_10_10 a impedância aumenta com o tempo e passa a apresentar valores superiores aos apresentados pelo tratamento T10_10 após maiores períodos de tempo. Dentre os tratamentos analisados, o tratamento T10_10_10 foi o que 
apresentou melhores resultados nos testes de corrosão acelerada em câmara de névoa salina e espectroscopia de impedância eletroquímica e os resultados iniciais até 11 dias indicaram a continuação das análises por períodos maiores de tempo de imersão em solução $0,1 \mathrm{~mol} \mathrm{~L}^{-1}$ de $\mathrm{NaCl}$. Estes foram continuados até 72 dias. Os resultados são apresentados na forma de diagramas de Nyquist e de ângulo de fase de Bode entre 1 e 7 dias, Figura 53, e entre 7 e 72 dias, Figura 53.
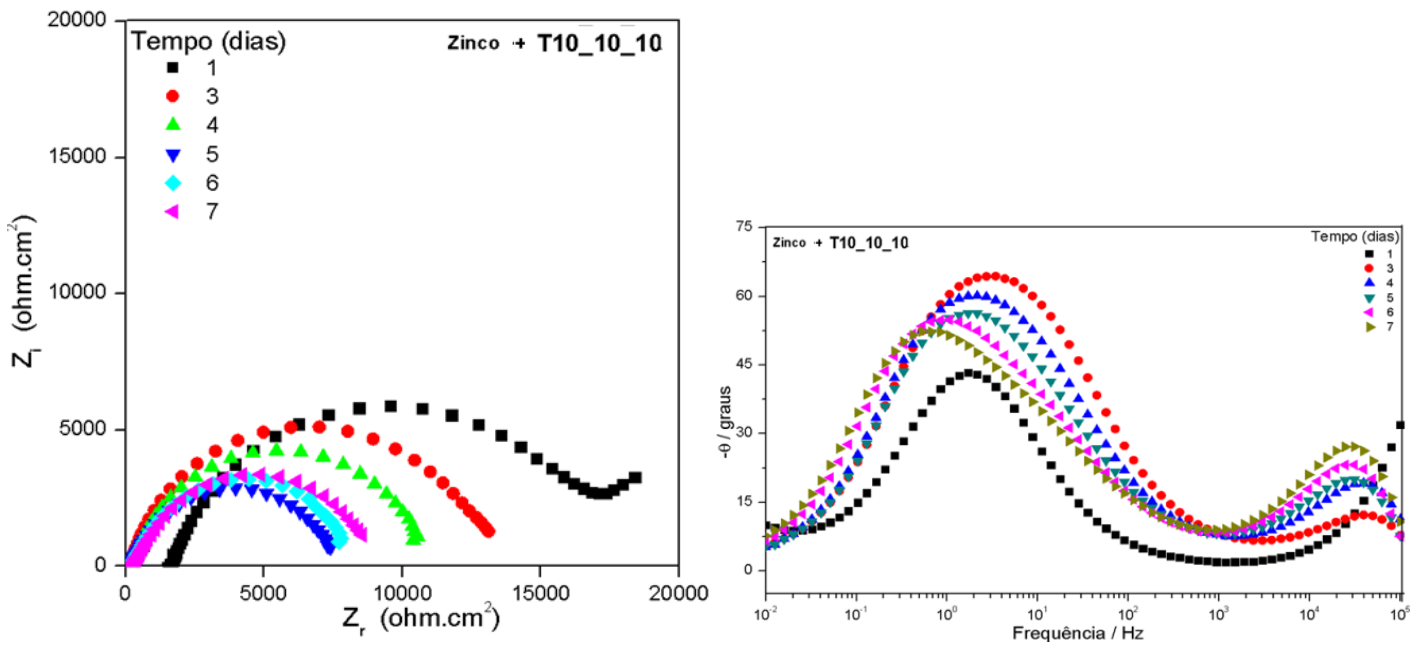

Figura 53: Diagramas de Nyquist para amostra com tratamento T10_10_10 após períodos de imersão entre 1 e 7 dias em solução 0,1 mol. $\mathrm{L}^{-1}$ de $\mathrm{NaCl}$.

A modificação do formato dos diagramas de impedância mostra evolução dos fenômenos interfaciais em função do tempo de imersão na solução de ensaio. Os diagramas de ângulo de fase de Bode obtidos para a amostra T10_10_10, revelam a presença de duas constantes de tempo bem definidas com diferentes tempos de relaxação até 7 dias de ensaio. A constante em altas frequências é atribuída à camada orgânica depositada na superfície do aço eletrozincado e a segunda constante, em frequências mais baixas, está correlacionada a fenômenos de transferência de carga na interface entre substrato metálico (zinco eletrodepositado) e o meio corrosivo, acoplado com o carregamento da dupla camada elétrica. O aumento do ângulo de fase a altas frequencias observado entre 3 e 7 dias e seu deslocamento para frequências menores, sugere a degradação desta camada com o tempo de exposição ao meio corrosivo. Esse resultado é corroborado pela diminuição da impedância em função do tempo de exposição, provavelmente pela maior exposição do substrado metálico ao meio 
corrosivo. A evolução da segunda constante de tempo, em frequencias mais baixas, que está relacionada a fenômenos de transferência de carga, mostra diminuição da impedância com o tempo, mas também o deslocamento da constante de tempo (pico) para frequencias mais baixas com o tempo de ensaio, indicando que a cinética deste processo está se tornando mais lenta.

Este resultado pode ser explicado pela formação crescente de produtos de corrosão do zinco, os quais são depositados na superfície e retardam os processos de corrosão, à medida que são acumulados na superfície exposta. É possível que a presença de cério na camada tenha também efeito retardador da cinética de corrosão, à medida que esta ocorre.

Na Figura 54 são apresentados os resultados eletroquímicos na forma de diagramas Nyquist e de ângulo de fase de Bode para amostra com o tratamento T10_10_10 após 7, 21, 28, 35, 41, 59, 62 e 72 dias de imersão em solução 0,1 mol. $\mathrm{L}^{-1}$ de $\mathrm{NaCl}$. Diferentemente dos resultados obtidos para os outros tratamentos testados, os quais mostraram diminuição da impedância com o tempo de imersão, o tratamento T10_10_10 resultou em aumento nos valores de impedância para períodos superiores a 7 dias de ensaio. Além disso, observou-se também o aparecimento de uma terceira constante de tempo.
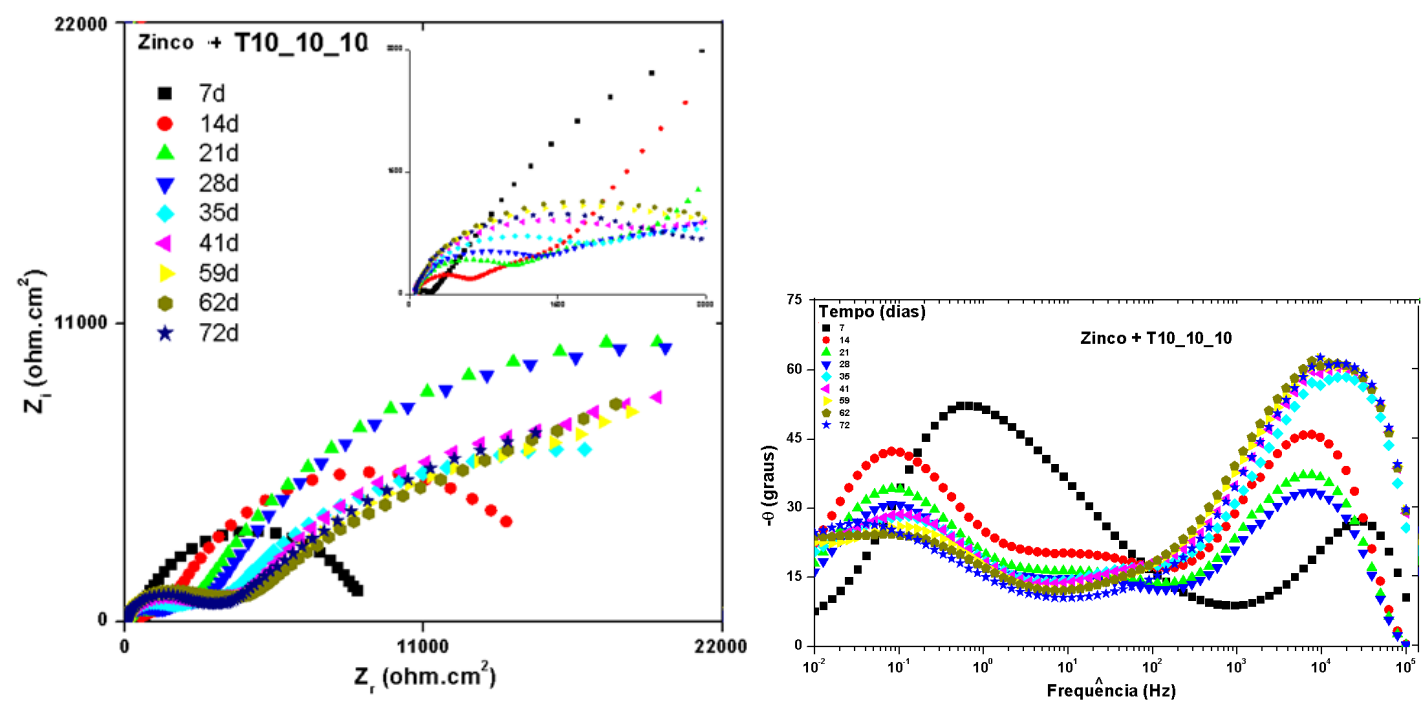

Figura 54: Diagramas de Nyquist e de ângulo de fase de Bode das amostras com tratamento T10_10_10 para 7, 14, 21, 28, 35, 41, 59, 62 e 72 dias de imersão em solução de $\mathrm{NaCl} 0, \overline{1} \mathrm{~mol} . \mathrm{L}^{-1}$. 
Em 14 dias de imersão, a terceira constante de tempo é indicada no inserto da Figura $53 \mathrm{~A}$, sendo que as três constantes de tempo são claramente vistas nos diagramas de ângulo de fase de Bode, principalmente para 14 e 21 dias de imersão. Atribui-se essa constante de tempo aos produtos de corrosão formados pelo contato do revestimento metálico (zinco) com o meio corrosivo.

O efeito deste acúmulo de produtos de corrosão se faz sentir também nas constantes de tempo a altas e baixas frequências. No caso das altas frequências, observa-se aumento nos ângulos de fase sem ocorrer o deslocamento do pico. Isto pode ser consequência do bloqueio e/ou preenchimento dos defeitos da camada orgânica formada pelos produtos de corrosão que ficam retidos na estrutura da camada, interpondo uma barreira entre o substrato e o meio corrosivo.

Esta suposição também é apoiada pelos resultados a baixas frequências, os quais indicam a influência de processos difusionais, tanto sugerida pelos ângulos de fase próximos a $45^{\circ}$ relativos aos picos nas baixas frequências para 21 e 28 dias de ensaio, e os ângulos de fase a cerca de 22,5ำ para tempos maiores, o que é explicado por processos de difusão, via camada porosa, promovida pelos produtos de corrosão depositados. A partir de 41 dias de ensaios, os resultados sugerem tendência a estabilização do sistema, sendo mais observadas grandes alterações nos diagramas de Nyquist ou de ângulo de fase de Bode. Os circuitos equivalentes mostrados na Figura 55 (A) e (B) são propostos para representar a superfície da amostra com o tratamento T10_10_10 em diferentes tempos de imersão.

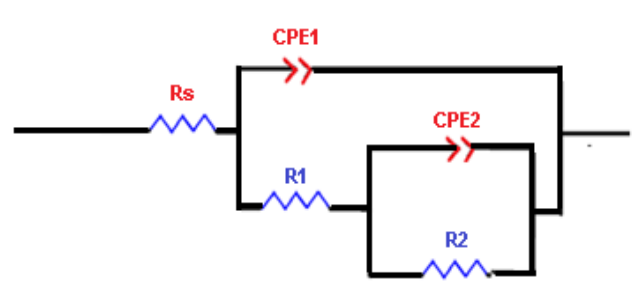

(A)

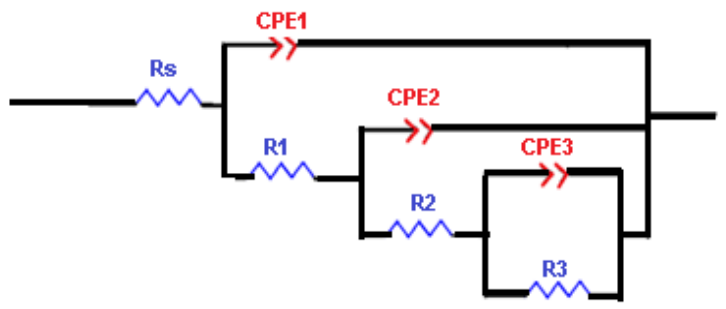

(B)

Figura 55: Circuitos elétricos equivalentes (CEE) propostos e usados nos ajustes dos resultados experimentais de espectroscopia de impedância eletroquímica: $(A)$ circuito proposto para os 7 primeiros dias, (B) circuito proposto para 14, 21, 28, $35,41,59,62$ e 72 dias de imersão em 0,1 mol. $\mathrm{L}^{-1} \mathrm{NaCl}$. 
O par $\mathrm{R}_{1} / \mathrm{CPE}_{1}$, em que $\mathrm{CPE}_{1}$ é um elemento de fase constante, descrevem a resposta de impedância em altas frequências, portanto, associada à camada orgânica formada. Como esta camada apresenta defeitos que expõem os produtos de corrosão formados na etapa 2 do tratamento, os quais são porosos e também expõe o substrato metálico ao meio corrosivo, um segundo par $\mathrm{R}_{2} / \mathrm{CPE}_{2}$, também em paralelo, é adotado para considerar os produtos óxidos formados na etapa 2 e os processos de transferência de carga.

$\mathrm{O}$ aumento nos valores de $\mathrm{CPE}_{2}$ para valores acima dos típicos de processos de transferência de carga (entre $20 \mu \mathrm{F} \mathrm{cm}{ }^{-2}$ e $60 \mu \mathrm{F} \mathrm{cm}{ }^{-2}$ ) apoiam a hipótese de estes estarem associados com os produtos óxidos formados. Os valores de $n_{2}$ que se aproximam de 0,85 entre 0,70 sugerem a combinação de processos de transferência de carga e de processos difusionais, provavelmente através da camada porosa dos produtos óxidos. Os erros associados a cada elemento do circuito elétrico equivalente foram menores que $10 \%$ e os valores obtidos dos ajustes dos elementos de circuito elétrico equivalente, Tabela 26.

Tabela 26: Valores dos elementos do circuito elétrico equivalente obtidos do ajuste dos dados experimentais ao modelo da Figura $54 \mathrm{~A}$, em função do tempo de imersão (1 a 7 dias) em 0,1 mol L ${ }^{-1}$ de $\mathrm{NaCl}$, para amostra T10_10_10.

\begin{tabular}{|c|c|c|c|c|c|c|c|c|}
\hline $\begin{array}{l}\text { Elementos do } \\
\text { circuito }\end{array}$ & $\begin{array}{c}\text { Tempo } \\
\text { (dias) }\end{array}$ & 1 & 2 & 3 & 4 & 5 & 6 & 7 \\
\hline 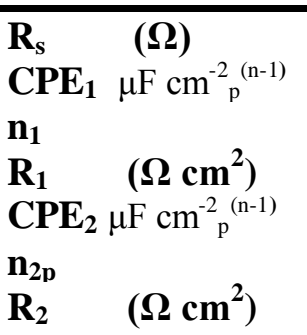 & & $\begin{array}{c}10 \\
32 \\
0,11 \\
1862 \\
21 \\
0,85 \\
32523\end{array}$ & $\begin{array}{c}32 \\
62 \\
0,84 \\
413 \\
40 \\
0,82 \\
15434\end{array}$ & $\begin{array}{c}100 \\
37 \\
0,96 \\
451 \\
59 \\
0,83 \\
13424\end{array}$ & $\begin{array}{c}65,8 \\
16 \\
0,74 \\
112 \\
78,5 \\
0,80 \\
11450\end{array}$ & $\begin{array}{c}65 \\
15 \\
0,77 \\
110 \\
111 \\
0,77 \\
7999\end{array}$ & $\begin{array}{l}61,1 \\
95 \\
0,81 \\
123 \\
150 \\
0,74 \\
6032\end{array}$ & $\begin{array}{c}56 \\
72 \\
0,82 \\
157 \\
168 \\
0,70 \\
11107\end{array}$ \\
\hline
\end{tabular}

Os valores da tabela acima confirmam as hipóteses propostas de deterioração da proteção da camada orgânica entre 1 e 7 dias de ensaio pela tendência de diminuição de $R_{1}$. Os valores de $n_{1}$ que se afastam de 1 são indicativos de defeitos na camada formada. Além disso, os valores de $\mathrm{CPE}_{2}$, comparativamente altos em relação a revestimentos orgânicos convencionais, 
mostram a contribuição de produtos óxidos porosos.

A diminuição nos valores da resistência $R_{2}$ entre 1 e 6 dias de ensaio é explicada pela penetração do eletrólito pela camada orgânica formada, e a incorporação do eletrólito nos poros da camada dos produtos de óxidos formados na etapa 2 do tratamento. Os valores de $\mathrm{n}_{2}$ mostram a crescente influência de processos difusionais no processo de corrosão do substrato. $O$ aumento nos valores de $\mathrm{CPE}_{2}$, passando a assumir valores superiores aos típicos de dupla camada elétrica para tempos superiores a 3 dias de ensaio, também apóiam a contribuição dos produtos de corrosão (óxidos/hidróxidos) formados durante o tratamento proposto e cuja formação é continuada durante exposição ao meio corrosivo.

Os valores dos elementos de circuito elétrico equivalente obtidos pelo ajuste dos dados experimentais, obtidos em tempos de imersão entre 7 e 72 dias de imersão, ao modelo proposto na Figura $54 \mathrm{~B}$, para amostra com tratamento T10_10_10, são mostrados na Tabela 27. O tempo de 7 dias de imersão, cujos resultados foram ajustados ao circuito da Figura $54 \mathrm{~A}$, é mostrado também nesta Tabela, para efeito de comparação dos valores obtidos pelo circuito com duas constantes de tempo.

Tabela 27: Valores dos elementos de circuito elétricos equivalentes obtidos a partir do ajuste dos dados experimentais para tempos entre 14 e 72 dias de imersão em solução $0,1 \mathrm{~mol}$. $\mathrm{L}^{-1}$ de $\mathrm{NaCl}$, amostra com tratamento T10_10_10.

\begin{tabular}{|c|c|c|c|c|c|c|c|c|c|}
\hline $\begin{array}{l}\text { Elementos do } \\
\text { circuito }\end{array}$ & $\underset{\text { dias }}{t}$ & 7 & 14 & 21 & 28 & 35 & 41 & 59 & 72 \\
\hline $\begin{array}{ll}\mathbf{R}_{\mathrm{s}} & (\boldsymbol{\Omega})\end{array}$ & & 56 & 69 & 60 & 67 & 64 & 66 & 65 & 59 \\
\hline $\mathbf{C P E}_{1} \mu \mathrm{F} \mathrm{cm}_{\mathrm{p}}^{-2(\mathrm{n}-1)}$ & & 72 & 22 & 64 & 32 & 34 & 35 & 37 & 67 \\
\hline$n_{1}$ & & 0,82 & 0,96 & 0,96 & 1 & 1 & 0,99 & 0,99 & 0,93 \\
\hline $\mathbf{R}_{1} \quad\left(\Omega \mathrm{cm}^{2}\right)$ & & 157 & 442 & 751 & 112 & 201 & 59 & 39 & 267 \\
\hline $\mathbf{C P E}_{3} \mu \mathrm{F} \mathrm{cm}_{\mathrm{p}}^{-2}(\mathrm{n}-1)$ & & & 208 & 75 & 62 & 49 & 55 & 61 & 107 \\
\hline $\mathbf{n}_{3}$ & & & 0,88 & 0,88 & 0,83 & 0,88 & 0,88 & 0,82 & 0,67 \\
\hline$R_{3} \quad\left(\Omega \mathrm{cm}^{-2}\right)$ & & & 18061 & 48255 & 128870 & 117630 & 100350 & 88478 & 76980 \\
\hline $\mathbf{C P E}_{2 \mathrm{pc}} \mu \mathrm{F} \mathrm{cm}_{\mathrm{p}}^{-2(\mathrm{n}-1)}$ & & 168 & 116 & 61 & 84 & 21 & 70 & 69 & 76 \\
\hline $\mathbf{n}_{2 p c}$ & & 0,70 & 0,52 & 0,40 & 0,22 & 0,22 & 0,21 & 0,20 & 0,17 \\
\hline$\left(\Omega \mathrm{cm}^{-2}\right)$ & & 1107 & 2039 & 4613 & 9493 & 12562 & 13577 & 14064 & 8194 \\
\hline
\end{tabular}

Os valores obtidos pelo ajuste dos dados de impedância eletroquímica mostram uma nova constante, representados pelos elementos $R_{3}, C P E_{3}$ e $n_{3}$ 
devido à presença de produtos de corrosão formados. Os valores de $R_{3}$ apresentam grande aumento entre 14 e 28 dias de imersão no eletrólito, o que mostra que neste período ocorrem transformações nos produtos de corrosão formados, os quais se tornam mais protetores.

Após esse período, o que se observa é uma tendência a estabilização da resposta eletroquímica, que em termos de resistência é da ordem de várias dezenas a poucas centenas de $\mathrm{k} \Omega \mathrm{cm}^{2}$. Em comparação aos valores de $R_{2}$, os valores de $R_{3}$ mostram que estes produtos são os principais responsáveis pela proteção à corrosão promovida pelo tratamento adotado em períodos prolongados de ensaio.

Esta proteção deve ser fortemente influenciada pela incorporação dos compostos de cério e de nióbio à camada, os quais parecem ancorar os produtos de corrosão do revestimento metálico (zinco) na estrutura do filme, permitindo que sofram transformações lentas, como por exemplo, a formação de simonkoleita, produto da corrosão do zinco, altamente insolúvel. Os comparativamente altos valores de $\mathrm{CPE}_{3}$ e $\mathrm{CPE}_{2}$ para 7 e 14 dias de ensaio indicam que há forte influência no $\mathrm{CPE}_{2}$ dos produtos de corrosão formados na etapa 2 do tratamento. A partir de 7 dias há provavelmente a formação de produtos de baixa solubilidade de zinco, cério e nióbio.

É interessante notar que os valores de $\mathrm{n}_{1}$ tendem a 1 a partir de 14 dias de ensaio, o que sugere que os defeitos no filme orgânico, formados após a terceira etapa do tratamento, tendem a ser reparados com a formação de uma camada contínua. Já os baixos valores de $\mathrm{n}_{2}$, por sua vez, indicam a interação de vários tipos de óxido (de cério, de zinco e de nióbio), bem como de processos de transferência de carga na interface do metal e o meio, o que corrobora com a hipótese de influência dos mecanismos reacionais relativos aos compostos incorporados ao filme orgânico formado.

Os resultados obtidos também sugerem leve e lenta degradação da camada de produtos de corrosão aderidos à superfície a partir de 28 dias de imersão, porém, até o término do ensaio, o principal responsável pela proteção ao substrato foi a camada de produtos formados, indicada pela resistência $R_{3}$ da 
ordem de dezenas a centenas $\mathrm{k} \Omega . \mathrm{cm}^{2}$, cerca de 10 vezes superiores à resistência do substrato metálico exposto ao meio.

De acordo com os resultados do ajuste, é possível propor que a camada orgânica formada promove inicialmente baixa proteção à corrosão do substrato metálico. Todavia, a incorporação dos compostos de cério e de nióbio a esta camada favorece a retenção dos produtos de corrosão na estrutura da camada e, com o tempo, a formação de uma camada mais contínua e que mantém os produtos de corrosão do substrato de zinco em sua estrutura, favorecendo o desenvolvimento de uma camada resistente e de proteção duradoura durante o tempo de contato com o meio corrosivo.

Propõe-se que os diferentes produtos de corrosão formados com o tempo de exposição ao meio, como óxidos de zinco, cério III e nióbio IV, bloqueiem parcialmente os poros e defeitos da camada que se torna cada vez mais protetora. A dissolução parcial de alguns destes produtos de corrosão resulta na pequena diminuição dos valores de impedância após 28 dias, mas também na formação de novos produtos (oxicloreto de zinco ou simonkoleita, óxidos de cério IV e óxido de nióbio V) que causam a estabilização da impedância entre 28 e 72 dias de ensaio.

\subsubsection{Modelos propostos}

Os resultados eletroquímicos obtidos foram ajustados a circuitos elétricos equivalentes e modelos foram propostos com base nos resultados experimentais. Os modelos propostos são mostrados nas Figuras 56, 57 e 58 para os tratamentos T10, T10_10 e T10_10_10, respectivamente. 


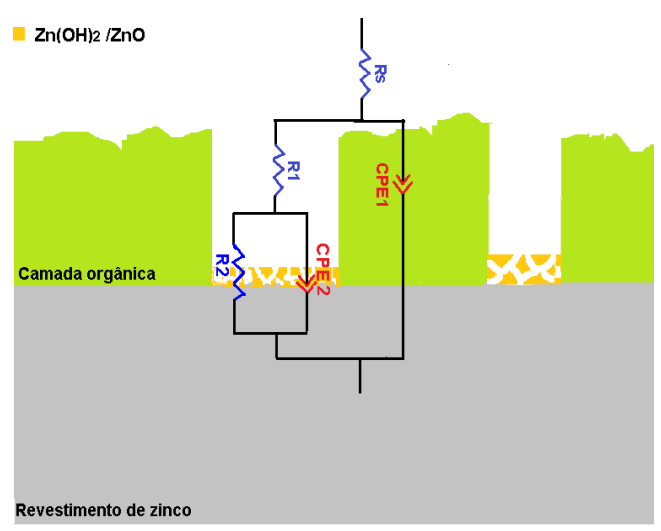

(A)

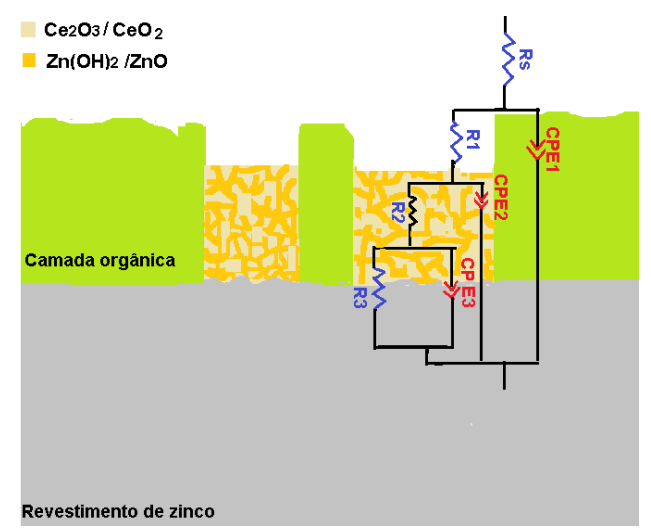

(B)

Figura 56: Circuitos elétricos equivalentes e modelos proposto para o mecanismo de corrosão das superfícies das amostras com o tratamento T10 após (A) 1 e 2 dias e (B) de 3 a 7 dias de imersão em solução 0,1 mol. $\mathrm{L}^{-1}$ de $\mathrm{NaCl}$.

O modelo sugerido de mecanismo de corrosão para o primeiro dia de imersão, com duas constantes de tempo, mostra a primeira constante relacionada ao filme orgânico e, a segunda constante, relacionada aos processos de transferência de carga entre o substrato metálico de zinco e o meio corrosivo. A terceira constante de tempo que aparece a partir do segundo dia é relacionada aos produtos de corrosão formados.

O fato do aparecimento desta constante, já a partir do segundo dia, devese à proteção insuficiente da camada formada por apenas uma etapa do tratamento, permitindo a intensa corrosão do substrato e o aparecimento da constante relacionada aos produtos formados em grande quantidade. $O$ que 
apontou para a necessidade de inclusão de outras etapas. O circuito elétrico equivalente e modelo proposto para o mecanismo de corrosão das superfícies das amostras com tratamento T10_10, após imersão em solução de $\mathrm{NaCl}$ 0,1 mol. $L^{-1}$ entre 1 e 7 dias é mostrado na Figura 57.

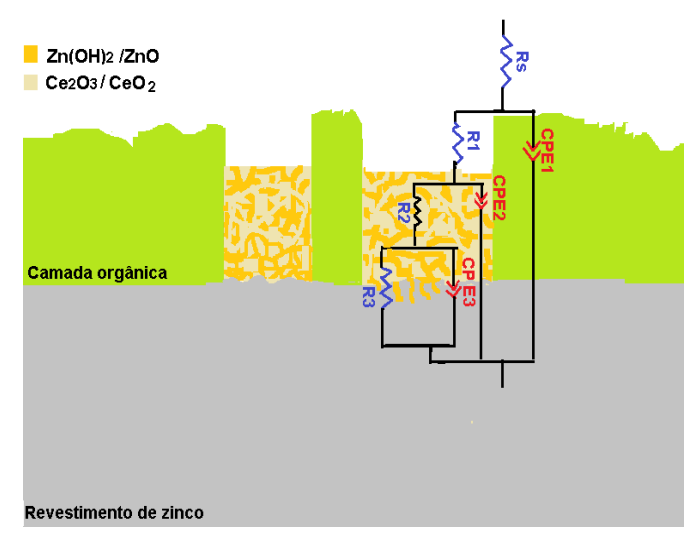

Figura 57: Circuito elétrico equivalente e modelo proposto para o mecanismo de corrosão das superfícies das amostras com o tratamento T10_10 entre 1 e 7 dias de imersão em solução $0,1 \mathrm{~mol} . \mathrm{L}^{-1}$ de $\mathrm{NaCl}$.

O mecanismo de corrosão sugerido para amostras com tratamentos T10_10 são similares ao mecanismo sugerido para amostra sem tratamento em solução de peróxido de hidrogênio, amostra com tratamento $T 10$, a partir do segundo dia de imersão em solução de cloreto de sódio $0,1 \mathrm{~mol} \cdot \mathrm{L}^{-1}$. O que justifica o aparecimento de três constantes de tempo, desde o primeiro dia de imersão para as amostras com o tratamento T10_10 é a etapa de imersão em uma solução com agente fortemente oxidante, peróxido de hidrogênio, o que favorece a formação de óxido de cério IV, bem como a oxidação do zinco, com a formação de quantidades significativas destes óxidos.

Apesar de haver uma maior quantidade de produtos de corrosão na superfície dos defeitos da camada orgânica para o tratamento T10_10 em relação ao T10, estes produtos conferem proteção ao revestimento por períodos de tempo maiores que os associados ao último tratamento, pois ambos os óxidos/hidróxidos, de zinco ou de cério, particularmente de cério IV, atuam como inibidores de corrosão. 
Essa foi a motivação para a inclusão desta etapa na sequência dos tratamentos propostos. $\mathrm{O}$ circuito elétrico equivalente e modelo proposto para o mecanismo de corrosão das superfícies das amostras com o tratamento T10_10_10, sob imersão em solução $0,1 \mathrm{~mol}^{-\mathrm{L}^{-1}}$ de $\mathrm{NaCl}$ entre 1 a 7 dias é mostrado na Figura 58.

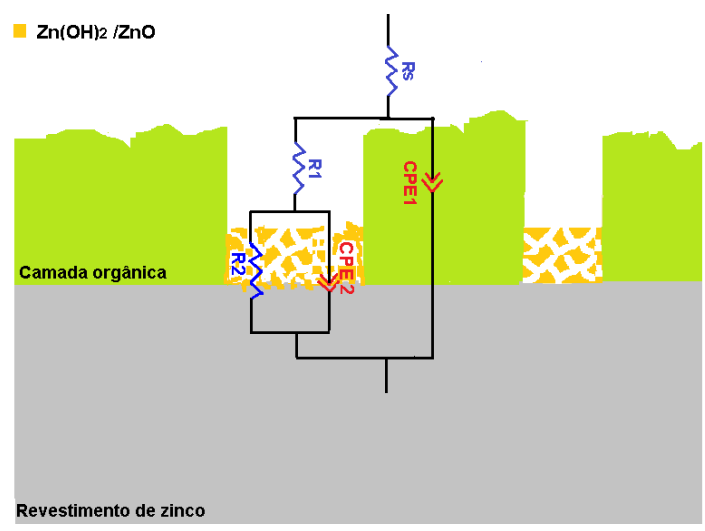

(A)

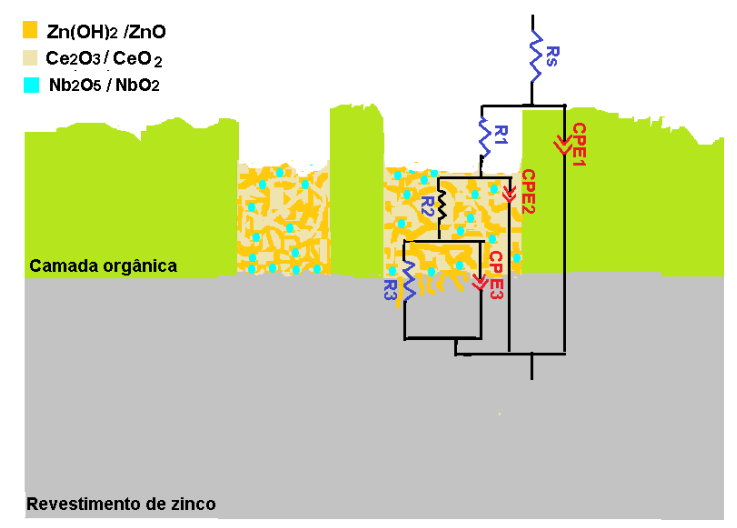

(B)

Figura 58: Circuitos elétricos equivalentes e modelos propostos para o mecanismo de corrosão das superfícies das amostras com o tratamento T10_10_10 para períodos entre (A) 1 e 7 dias e (B) de 14 a 72 dias de imersão em solução $0,1 \mathrm{~mol}^{-L^{-1}}$ de $\mathrm{NaCl}$.

Os mecanismos de corrosão sugeridos para amostras com tratamentos T10_10_10 são de duas constantes para os sete primeiros dias de imersão. O recobrimento dos produtos formados na etapa de imersão em solução oxidante 
(peróxido de hidrogênio), ou etapa 2, pela formação de filme orgânico com composto de nióbio, na etapa 3 do tratamento, explica a presença de apenas duas constantes de tempo entre 1 e 7 dias de imersão para as superfícies com este tratamento.

A camada formada na etapa 3 protege 0 revestimento metálico promovendo uma barreira entre este e o meio corrosivo. Apenas para períodos superiores a 7 dias, especificamente no caso mostrado, a partir de 14 dias, aparece uma terceira constante de tempo. Conforme proposto, a terceira constante de tempo deve-se à contribuição dos produtos de corrosão formados após a penetração da camada orgânica pelo meio corrosivo e a incorporação destes nos poros dos produtos de corrosão formados durante o tratamento de imersão em solução oxidante.

A oxidação do óxido de cério de valência 3 para valência 4 , o qual foi incorporado no filme orgânico, bem como a presença de composto de nióbio incorporado ao filme, além da oxidação dos produtos de corrosão do zinco (hidróxido de zinco) a óxidos e oxicloretos de zinco, produto de baixa solubilidade, promove estabilidade da superfície, indicada pelos altos valores de impedância obtidos por longos períodos de ensaio (72 dias).

É possível que o tratamento T10_10_10 promova a formação de camada orgânica que funciona como uma rede estrutural de suporte para os produtos de corrosão formados, promovendo a ancoragem destes produtos, os quais, sofrem oxidação com o tempo, se transformado em óxidos de baixa solubilidade e, portanto, conferindo proteção por camada barreira entre o meio e o substrato. 


\section{CONCLUSÕES}

Os resultados do presente trabalho permitem concluir que os tratamentos adotados resultaram na formação de camadas orgânicas na superfície do aço eletrozincado. Os parâmetros dos processos utilizados permitiram a escolha de um tratamento que se mostrou efetivo quanto ao objetivo proposto de deposição de camada orgânica protetora sobre aço eletrozincado.

Os tratamentos consistiram de etapas consecutivas de imersão em soluções, as quais continham cério ou nióbio, e um composto orgânico (2 butino 1,4 diol propoxilato), que atuou como precursor polimérico. Uma etapa intermediária de imersão em solução oxidante contendo peróxido de hidrogênio se mostrou efetiva para a formação de produtos de corrosão protetores e, deposição de cério IV, presente na camada como cério III e aumento na proteção à corrosão. $O$ efeito do tratamento de cada uma das etapas estudadas nas características da camada formada foi investigado, observando-se uma crescente melhora na resistência à corrosão com o aumento no número de etapas, desde que o tempo de imersão não excedesse 10 minutos.

O efeito do tempo de tratamento nas características da camada formada foi investigado e dentre os tempos testados (1, 10 e 20 minutos), o tempo de 10 minutos foi o que apresentou melhores características quanto à redução no número e extensão de defeitos nas camadas obtidas. O tempo de 1 minuto mostrou-se insuficiente para a proteção efetiva e o de 20 minutos excessivo, causando intenso ataque da superfície metálica, revestimento de zinco.

A caracterização da composição química da camada formada pelas etapas 1 e 2 mostrou a incorporação de cério na forma de óxidos em dois estados de oxidação (III e IV), provavelmente nas formas $\mathrm{Ce}_{2} \mathrm{O}_{3}$ e $\mathrm{CeO}_{2}$. O tratamento de imersão em solução com composto orgânico (2 butino 1,4 diol propoxilato) e composto de nióbio (ANO), também chamado de etapa 3, resultou na incorporação de nióbio, seja na forma de $\mathrm{NbO}_{2} \mathrm{e} \mathrm{Nb}_{2} \mathrm{O}_{5}$. As camadas formadas após as várias etapas adotadas contêm uma estrutura polimérica formada por 
filme orgânico e uma mistura de óxidos, particularmente óxido e hidróxido de zinco, os quais ficam retidos na estrutura da camada e conferem a proteção à corrosão do substrato metálico por períodos prolongados de imersão.

Os resultados do ensaio em câmara de névoa salina indicaram maior resistência à corrosão em relação à proporcionada pela camada de conversão de cromato, para a camada obtida pelo tratamento T10_10_10, que consistiu das três etapas propostas e em cada uma delas adotando-se o tempo de tratamento correspondente a 10 minutos. O tempo para aparecimento, tanto dos produtos de corrosão branca como os produtos de corrosão vermelha, foram superiores para este último tratamento em comparação aos obtidos para a superfície com camada de conversão de cromato.

Os resultados do ensaio em câmara de névoa salina foram corroborados pelos dos ensaios de espectroscopia de impedância eletroquímica, os quais mostraram que a superfície com o tratamento T10_10_10 proporcionou proteção prolongada ao substrato de aço eletrozincado. Este tratamento mostra-se, portanto, uma alternativa viável para substituição de cromatos no tratamento de aços eletrozincados, tanto do ponto de vista de preservação ambiental, por se tratar de tratamento ecologicamente amigável, como de resistência à corrosão, por proporcionar proteção superior à dos cromatos, além de ser um tratamento de custo relativamente baixo por envolver pequenas quantidades de composto orgânico e aditivo. 


\section{SUGESTÕES PARA TRABALHOS FUTUROS.}

A seguir são dadas sugestões para a continuidade destas pesquisas em trabalhos futuros, a saber:

$\checkmark$ Continuação do estudo da estrutura das camadas orgânicas obtidas, particularmente da forma como o cério e seus óxidos e os óxidos de nióbio incorporados nas camadas.

$\checkmark$ Emprego de outras técnicas analíticas, como Focused lon Beam (FIB) e de eletrodo vibratório de varredura (SVET), para a investigação se há propriedade de autorregeneração para as camadas formadas.

$\checkmark \quad$ Caracterização da resistência à corrosão dos tratamentos selecionados após aplicação de tintas e vernizes por ensaios acelerados em câmara de névoa salina.

$\checkmark$ Caracterização da superfície com os tratamentos selecionados após ensaios de corrosão por diferentes tempos de imersão por meio do emprego da técnica de espectroscopia fotoeletrônica de raios-X (XPS).

$\checkmark \quad$ Agrupar etapas com objetivo de se ter o menor número possível de etapas como forma mais viável para aplicação industrial.

$\checkmark$ Obter relação custo / benefício do tratamento T10_10_10 comparativamente aos tratamentos de conversão com cromo hexavalente. 


\section{PUBLICAÇÕES RESULTANTES DESTA TESE}

\section{ARTIGO PUBLICADO EM PERIÓDICO}

J. M. Ferreira Jr., J. L. Rossi, M.A. Baker, S.J. Hinder, I. Costa. Deposition and Characterization of a New Mixed Organic/Inorganic Cerium Containing Coating for the Corrosion Protection of Electrogalvanized Steel. International Journal of Electrochemical, 9 (2014).

\section{TRABALHOS EM ANAIS DE EVENTOS}

Ferreira Jr, J.M.; Souza, E.C.; de Melo, H. G.; BAKER, M. A.; Costa, I. Surface Treatment with Niobium Oxalate for Passivity of Electrogalvanized Steel. In: 10 th International Symposium on the Passivation of Metals, 2011, 2011.

Ferreira Jr, J.M.; Tomachuk, C. R.; Oliveira, M.; Izaltino, W.A.S ; Costa, I. . Investigação de tratamentos alternativos à cromatização aplicados sobre eletrogalvanizado. In: III INTERFINISH Latino Americano, 2012, São Paulo, ABTS, 2012, v 1, p 5-5.

Ferreira Jr, J.M.; Tomachuk, C. R.; Costa, I.; Izaltino, W.A.S. Investigação de tratamentos alternativos à cromatização, sobre superfícies de aço galvanizado, In: Intercorr - Abraco, 2012, Salvador, São Paulo: Abraco, 2012, v1, p 7-7.

Ferreira Jr, J.M.; Costa, I. ; Rossi, J. L.; Tomachuk, C. R.; Baker, M. A.; Hinder, S.; Izaltino, W.A.S. A Combination of Cerium and Niobium Treatments for Corrosion Protection, In: 10th Symposium on electrochemical methods in corrosion research, 2012, MARAGOGI, v1, p 1-1.

Oliveira, M.; Ferreira Jr, J.M.; Izaltino, W.A. S; TOMACHUK, C. R.; COSTA, I. Avaliação de camadas de conversão de cério como alternativa para a substituição de cromatização sobre aço eletrozincado, III INTERFINISH Latino Americano, São Paulo: ABTS, 2012, v1, p 3-3. 


\section{REFERÊNCIAS BIBLIOGRÁFICAS}

ABRÃO, A. Química e tecnologia das terras-raras. Rio de Janeiro: CETEM, CNPq, 1994. 212 p. (Série Tecnologia Mineral, 66) Centro de Tecnologia Mineral. 11. Título. 111.

ALDYKEWICZ, A. J., ISAACS, H. S., DAVENPORT, A. J. The Investigation of Cerium as a Cathodic Inhibitor for Aluminum-Copper Alloys. Journal of the Electrochemical Society, v 142, n 10, p 3342-3350, 1995.

ALMEIDA, E. L. FEDRIZZI, T.C. DIAMANTINIO. Oxidizing Alternative Species to Chromium VI in Zinc-Galvanized Steel Surface Treatment. Part 1- an Electrochemical Study. Surface and Coatings Technology, v 105, n 97-101, 1998.

ALMEIDA, E. T.C. DIAMANTINO, M.O. FIGUEIREDO, C. SA. Oxidizing Alternative Species to Chromium VI in Zinc-Galvanized Steel Surface Treatment. Part -2 A Morphological and Chemical Study. Surface and Coatings Technology, v 106, 1998.

AMADEH, A.; PAHLEVANI, B.; HESHMATI-MANESH, S. Effects of rare earth metal addition on surface morphology and corrosion resistance of hot-dipped zinc coatings. Corrosion Science, v 44, n 10, p 2321, 2002.

ANDERS, A., YUSHKOV, G. Y. Plasma "anti-assistance" and "self-assistance" to high power impulse magnetron sputtering. Journal of Applied Physics, v. 105, n. 7, p. 073301, 2009.

ANFAVEA - Associação Nacional dos Fabricantes de Veículos Automotivos, Disponível em www.anfavea.com.br/coletiva.pdf - acesso 25/11/2013.

ARAMAKI, K. Preparation of chromate-free, self-healing polymer films containing sodium silicate on zinc pretreated in a cerium (III) nitrate solution for preventing zinc corrosion at scratches in $0.5 \mathrm{M} \mathrm{NaCl}$. Corrosion Science, v 44, n 6, p 13751389, 2002.

ARAMAKI, K. The Inhibitions Effects of Cation Inhibitors on Corrosion of Zinc in Aerated 0.5 M NaCl. Corrosion Science, v 43, p 1573-1588, 2001.

ARDELEAN, H., FRATEUR, I., MARCUS, P. Corrosion protection of magnesium alloys by cerium, zirconium and niobium-based conversion coatings. Corrosion Science, 50(7), 1907-1918, 2008.

ASTM B117 - AMERICAN SOCIETY FOR TESTING AND MATERIALS (ASTM), Standard Practice for Preparing, Operating Salt Spray (Fog) Apparatus: B117: 1991. Philadelphia: Annual Book of ASTM Standards. 
AUINAT, M., EIN-ELI, Y. Enhanced inhibition of zinc corrosion in alkaline solutions containing carboxylic acid modified PEG. Journal of the Electrochemical Society, 152(6), A1158-A1164, 2005.

BABOIAN, R. Corrosion Tests and Standards: Application and Interpretation. Second edition, p 78-198, 2005.

BAKER, M.A. ASSIS, S.L.DE. HIGA, O.Z. COSTA, I. Nanocomposite Hydroxyapatite Formation on a Ti-13Nb-13Zr alloy Exposed in a MEM Cell Culture Medium and the Effect of $\mathrm{H}_{2} \mathrm{O}_{2}$ Addition. Acta Biomaterialia, v 5, p 63-75, 2009.

BANCZEK, E. P. Desenvolvimento e caracterização de camadas de fosfato de zinco/níquel e zinco/nióbio. 2008. Tese (Doutorado em Tecnologia Nuclear Materiais) - Instituto de Pesquisas Energéticas e Nucleares, Universidade de São Paulo, São Paulo, 2008.

BANCZEK, E. P. et al. Effects of Niobium Ammonium Oxalate and Benzotriazole on the Corrosion Resistance of Zinc Phosphate Layer. Journal of Materials Engineering and Performance, v 22, n 11, p 3572-3583, 2013.

BARAL, A., ENGELKEN, R. D. Chromium-based regulations and greening in metal finishing industries in the USA. Environmental Science \& Policy, v 5, n 2, p 121-133, 2002.

BARAL, A., ENGELKEN, R., STEWART, P. Chromium-Based Regulations Applicable to Metal Finishing Industries in the United States: A Policy Assessment. Review of Policy Research, v 23, n 1, p 1-21, 2006.

BARROS FILHO, D. A. et al. Sensitization of Niobium Pentoxide Thin Films by cisDithiocyanate (2, 2-bipyridyl-4, 4' dicarboxylic acid) Ruthenium (II) Complex. Journal of Sol-Gel Science and Technology, v 18, n 3, p 259-267, 2000.

BARRY, J., LAVIGNE, M., VENDITTOLI, P. A. Evaluation of the Method for Analyzing Chromium, Cobalt and Titanium lon Levels in the Blood Following Hip Replacement with a Metal-on-Metal Prosthesis. Journal of Analytical Toxicology, v 37, n 2, p 90-96, 2013.

BÊCHE, Eric et al. Ce 3d XPS investigation of cerium oxides and mixed cerium oxide (CexTiyOz). Surface and Interface Analysis, v 40, n 3-4, p 264-267, 2008.

BENDAVID, A., MARTIN, P.J., KINDER, T.J., PRESTON, E.W. The Deposition of $\mathrm{NbN}$ and $\mathrm{NbC}$ Thin Films by Filtered Vacuum Cathodic Arc Deposition. Surface Coating and Technology, v 163/164, p 347-352, 2003.

BIERWAGEN, G. P., WANG, DUHUA. Review Sol-Gel Coatings on Metals for Corrosion Protection. Progress in Organic Coatings, v 64, n 4, p 327-338, 2009.

BIESINGER, M. C., PAYNE, B. P., GROSVENOR, A. P., LAU, L. W., GERSON, A. R., SMART, R. S. C. Resolving surface chemical states in XPS analysis of first 
row transition metals, oxides and hydroxides: $\mathrm{Cr}, \mathrm{Mn}$, Fe, Co and Ni. Applied Surface Science, 257:7, 2717-2730, 2011.

BIESTEK, T. Comparative corrosion testing of eight systems of electrodeposited protective-decorative $\mathrm{Ni} / \mathrm{Cr}$ and $\mathrm{Cu} / \mathrm{Ni} / \mathrm{Cr}$ coatings on steel II: Field tests. Surface Technology, v 21, n 3, p 295-300, 1984.

BISWICK, T. Evidence for the formation of anhydrous zinc acetate and acetic anhydride during the thermal degradation of zinc hydroxy acetate, $\mathrm{Zn}_{5}(\mathrm{OH})_{8}$ $\left(\mathrm{CH}_{3} \mathrm{CO}_{2}\right)_{2} \cdot 4 \mathrm{H}_{2} \mathrm{O}$ to $\mathrm{ZnO}$. Solid State Sciences, v. 11, p. 330-335, 2009.

BRANDÃO, Rodrigo F. et al. Synthesis, characterization and use of $\mathrm{Nb}_{2} \mathrm{O}_{5}$ based catalysts in producing biofuels by trans esterification, esterification and pyrolysis. Journal of the Brazilian Chemical Society, v 20, n 5, p 954-966, 2009.

BRIGGS, D., BEAMSON, G. Primary and secondary oxygen-induced C1s binding energy shifts in X-ray photoelectron spectroscopy of polymers. Analytical chemistry, v 64, n 15, p 1729-1736, 1992.

BYOUNG, Y.C., SU-MOON, P. Electrochemical Impedance Spectroscopy Annual Review of Analytical Chemistry, v 3, p 207-29, 2010.

CABISTANI, D. E. O. S., Estudo de Aditivos Comerciais para Banhos Alcalinos Comerciais com e sem Cianeto na Eletrodeposição de Zinco- Diss. Mest, PPGEMM/UFRGS, 1994.

CAPILLA, A. V., ARANDA, R. A. Anhydrous zinc (II) acetate (CH3COO)2Zn. Crystalline Structure Com, v 8, p 795-798, 1979.

CAMPESTRINI, P., WESTING, E.P.M., HOVESTAD, A., WIT, J.H.W. Investigation of the Chromate Conversion Coating on Alclad 2024 Aluminium Alloy: Effect of the pH of the Chromate Bath. Electrochimica Acta, v 47, p 1097 - 1113, 2002.

CASTLE, J. E. A Wizard Source of Expertise in XPS, Surface and Interface Analyses; v 33, p 196-202, 2002.

CATAURO, M. et al. Influence of the drying treatment on the performance of $\mathrm{V}-\mathrm{Nb}$ mixed oxides catalysts synthesized via sol-gel. Journal of Non-Crystalline Solids, v 380, p 1-5, 2013.

CAVALHEIRO, A. A.; ZAGHETE, M. A. and VARELA, J. A.. Influência do oxalato de amônio na formação do precursor columbita obtido pelo método Pechini. Cerâmica, v 45, n 292, p 56-60, 1999.

CHAVAN, N., M. et al. The Corrosion Behavior of Cold Sprayed Zinc Coatings on Mild Steel Substrate. Journal of Thermal Spray Technology, p 1-8, 2013. 
CHO, K., SHANKAR, R., KWON, V. Microstructure and electrochemical characterization of trivalent chromium based conversion coating on zinc. Electrochimica Acta, v 52, n 13, p 4449-4456, 2007.

CLEGG, W., LITTLE, I. R., STRAUGHAN, B. P. Monoclinic anhydrous zinc (II) acetate. ACTA CRYSTALLOGRAPHICA SECTION C: CRYSTAL STRUCTURE COMMUNICATIONS, v 42, n 12, p 1701-1703, 1986.

COHEN, MD., KARGACIN, B., KLEIN CB., COSTA, M. Mechanisms of Chromium Carcinogenicity and Toxicity. Critical Reviews in Toxicology, v 23, n 3, p 255281, 1993.

CORNISH, L., WATSON, A. Carbon-Iron-Niobium. In: Iron Systems, Part 2. Springer Berlin Heidelberg, p 246-266, 2008.

EGILMAN, DAVID. Corporate corruption of science - the case of chromium (VI). International Journal of Occupational and Environmental Health, Electrochimica Acta, v 52, p 4449-4456, 2007.

ESTRADE-SZWARCKOPF, H. XPS photoemission in carbonaceous materials: A "defect" peak beside the graphitic asymmetric peak. Carbon, 42(8), 1713-1721, 2004.

FERREIRA JR, J. M.; TOMACHUK, C. R.; IZALTINO, W.A.S.; COSTA, I. Investigação de Tratamentos Alternativos à Cromatização Sobre Superfícies de Aço Galvanizado. In: Intercorr, Salvador, 2012.

FERREIRA JR., COSTA, I.; SOUZA, E.C.; J.M.; MELO, H.G.; BAKER, M. A. 10th International Symposium on the Passivation of Metals, 2011, Florianópolis. Passivity 10, v 1, p 1-1, 2011.

FLEISCHANDERL, M. et al. Developing of thin Chromium-Free Multifunctional Treatments on Hot Dip Galvanized Steel-Strategy, Implementation and Experience. BHM Berg-und Hüttenmännische Monatshefte, v 157, n 3, p 113120, 2012.

GEDULD, H. A Survey of Zinc Plating - Part 3 Impurities. Problem in Cyanide Baths. Metal Finishing, p 50-52, 1975.

GIGANDET, M. P.; FAUCHEU, J.; TACHEZ, M. Formation of black chromate conversion coatings on pure and zinc alloy electrolytic deposits: role of the main constituents. Surface and Coatings Technology, v 89, n 3, p 285-291, 1997.

GRUNDMEIER, G.; SCHMIDT, W.; STRATMANN, M. Corrosion protection by organic coatings: electrochemical mechanism and novel methods of investigation. Electrochimica Acta, v 45, n 15, p 2515-2533, 2000. 
GUPTA, S. K., GINGERICH, K. A. Mass spectrometric study of the stabilities of gaseous carbides of vanadium, niobium, and molybdenum. The Journal of Chemical Physics, v 74, p 3584, 1981.

HAGANS, P. L.; HAAS, C. M. Chromate conversion coatings. ASM International, Member/Customer Service Center, Materials Park, OH 44073-0002, USA, 1994., p 405-411, 1994.

HAMLAOUI, Y. et al. Cathodic electrodeposition of cerium-based oxides on carbon steel from concentrated cerium nitrate solutions: part I. Electrochemical and analytical characterization. Materials Chemistry and Physics, v 113, n 2, p 650657, 2009.

HAMLAOUI, Y.; TIFOUTI, L.; PEDRAZA, F. Corrosion monitoring of Galvanized Coatings through Electrochemical Impedance Spectroscopy. Corrosion Science, v 50, p 1558-1566, 2008.

HAMLAOUI, Y.; TIFOUTI, L.; PEDRAZA, F. Corrosion Protection of ElectroGalvanized Steel by Ceria-Based Coatings: Effect of Polyethylene Glycol (PEG) Addition. Journal of Materials Engineering and Performance, p 1-10, 2013.

HASSEN, S.B., BOUSSELMI, L., BERÇOT, P., REZRAZI, E.M., TRIKI, E. Improvement of corrosion resistance of magnesium coating with cerium treatment, Rare Met., v. 28, n. 3, p.277, 2009.

HASSEN, S.B., BOUSSELMI, L., BERÇOT, P., REZRAZI, E.M., TRIKI, E. Comparative study of protective magnesium deposit behaviour obtained by continuous and pulsed currents from methyl magnesium chloride solution, Surface Coating Technology, v 202, n 5, p 3579, 2008.

HINTON, B. R. W. Corrosion inhibition with rare earth metal salts. Journal of Alloys and Compounds, v 180, n 1, p 15-25, 1992.

HINTON, B. R. W.; WILSON, L. The corrosion inhibition of zinc with cerium chloride. Corrosion Science, v 29, n 8, p 967-985, 1989.

HOSSEINI, M., ASHASSI-SORKHABI, H., GHIASVAND, H. A. Y. Corrosion protection of electro-galvanized steel by green conversion coatings. Journal of Rare Earths, v 25, n 5, p 537-543, 2007.

HUANG, B. X., WANG, K., CHURCH, J. S., LI, Y. S. Characterization of oxides on niobium by Raman and infrared spectroscopy. Electrochimica Acta, 44(15), 2571-2577, 1999.

HUGHES, A. E. et al. Designing green, self-healing coatings for metal protection. NPG Asia Materials, v 2, n 4, p 143-151, 2010.

ISHII, K., KIMOTO, M., YAKAWA, A. Effect of Crystal Orientation on Properties of Zinc Electroplated Steel Sheets. Galvatech'98 Conference Proceedings. Chiba, Japan. The Iron and Steel Institute of Japan, p 547-552, 1998. 
JOHANSSON, E., NYBORG, L. XPS study of carboxylic acid layers on oxidized metals with reference to particulate materials. Surface and interface analysis, $v$ 35, n 4, p 375-381, 2003.

JOHNSON, M. K.; POWELL, D. B.; CANNON, R. D. Vibrational spectra of carboxylate complexes-I. Infrared and Raman spectra of beryllium (II) acetate and formate and of zinc (II) acetate and zinc (II) acetate dihydrate. Spectrochimica Acta Part A: Molecular Spectroscopy, v. 37, n. 10, p. 899-904, 1981.

JUDAH, LAMIS. DNA damage by oxo-and peroxo-chromium (v) complexes: insight into the mutation and carcinogenesis mechanisms. Toxicology Research, v 3, n 1, p 56-66, 2014.

KEDDAM, M. et al. The influence of a thin electrolyte layer on the corrosion process of zinc in chloride-containing solutions. Corrosion Science, v 33, n 8, p 1243-1252, 1992.

KENDIG, M. W., DAVENPORT, A. J., Isaacs, H. S. The Current-Time Relationship during Anodic Oxide Film Growth under High Electric Field. Corrosion Science, v 34, n 41, 1993.

KILBOURN, B. T. Cerium: A guide to its role in chemical technology. New York: Molycorp, 1992.

KILBOURN, B. T. Journal of the Less-Common Metals, v126, p 101-106, (1986).

KLEMAN, L. H. Use of Degrees of Unsaturation in Solving Organic Structural Problems. Journal of Chemical Education, v 72, 425, 1995.

KOBAYASHI, Y., FUJIWARA, Y. Effect of SO4 on the corrosion behavior of cerium-based conversion coatings on galvanized steel. Electrochimica Acta, $v$ 51, n 20, p 4236-4242, 2006.

KOROTKOV, A. S.; ATUCHIN, V. V. Distribution, structures and nonlinear properties of noncentrosymmetric niobates and tantalates. Journal of Solid State Chemistry, v 179, n 4, p 1177-1182, 2006.

KOTZ, JOHN C.; TREICHEL JUNIOR, PAUL M. Química Geral e Reações Químicas. v 1, 5a ed, São Paulo: Pioneira Thomson, 2005.

LABINGER, J. A.; WONG, K.S., SCHEIDT, W. R. Approaches to homogeneous reduction of carbon monoxide: reaction of niobium hydrides with coordinated carbon monoxide. Journal of the American Chemical Society, v 100, n 10, p 3254-3255, 1978.

LAMB, A.; EVANS, G.; KING, J. R. Mathematical Modelling of Toxicity Associated with Intracellular Chromium Reduction. Bulletin of Mathematical Biology, v 2, p 1-29, 2013. 
LEADLEY S. R. \& J. F. WATTS: The Use of Monochromated XPS to Evaluate Acid-Base Interactions at the PMMA/Oxidized Metal Interface. The Journal of Adhesion, v60, n 1-4, 175-196, 1997.

LI, C., SAKATA, Y., ARAI, T., DOMEN, K., MARUYA, K. I., \& ONISHI, T.. Carbon monoxide and carbon dioxide adsorption on cerium oxide studied by Fouriertransform infrared spectroscopy. Part 1.-Formation of carbonate species on dehydroxylated $\mathrm{CeO}$, at room temperature. Journal Chemical Society, Faraday Trans, 1, 85: 4, 929-943, 1989.

LONG, J. M. et al. Surface Modification on Zinc and Galvanized Steel with Cerium Nitrate Journal. Chinese Rare Earths, v 5, p 16, 2003.

LOWENHEIN, F. A. Electroplating: Fundamentals of source finishing. Mac Graw Hill, New York, p 232-233, 1978.

LU, J. T. et al. Growth and corrosion behavior of rare earth film on hot-dip galvanized steel. Transactions of Nonferrous Metals Society of China, v 16, n 6, p 1397-1401, 2006.

LU, J.T. K.GANG, C. J.H. XU, Q.Y.U, SUIRUN. Growth and Corrosion Behaviour of Molybdate Passivation Film on Hot Dip Galvanized Steel. Journal Transactions of Nonferrous Metals Society of China, v 13, n 1, p145-148, 2003.

MAEGE, I. Ultrathin organic layers for corrosion protection. In: Macromolecular Symposia. Hüthig \& Wepf Verlag, p 7-24, 1998.

MARTYAK, N. M., MCCASKIE, J.E., HARRISON, L. Corrosion Behavior of Zinc Chromate Coatings. Atotech USA Inc., Indianapolis, p 561; 1994.

MCBRIDE, J. R., HASS, K. C., POINDEXTER, B. D., WEBER, W. H. Raman and x-ray studies of CeREO, where $\mathrm{RE}=\mathrm{La}, \mathrm{Pr}, \mathrm{Nd}, \mathrm{Eu}, \mathrm{Gd}$, and $\mathrm{Tb}$. Journal of Applied Physics, v 76, p 2435, 1994.

MCCARTHY. Quality Control on an Industrial Scale at the La Rochelle Rare Earths Plant, The Rare Earths in Modern Science and Technology, v 2, 517526, Copyright, 1980.

MCCARTHY; G. J., SILBER, H. P., RHYNE (Eds.), J. J. The Rare Earths in Modem Science and Technology. Plenum Press, New York, 1982.

MEHROTRA, R. C., BOHRA, R., GAUR, D. P. Metal carboxylates. London: Academic Press, 1983.

MILLER, C.F., SIMMONS, G.W., WEI, R.P. Corrosion Fatigue Crack Growth of Steels in Aqueous Solutions I: Experimental Results and Modeling the Effects of Frequency and T. Script Materials, v 42, p 227-232, 1993. 
MOHAMMADI, S., GOLOBOSTANFARD, M. R.; ABDIZADEH, H. Synthesis and Characterization of Indium Niobium Oxide Thin Films via Sol-Gel Spin Coating Method. Journal of Materials Science \& Technology, v 29, n 10, p 923-928, 2013.

MONTEMOR, M. F.; SIMOES, A. M.; FERREIRA, M. G. S. Composition and corrosion behaviour of galvanised steel treated with rare-earth salts: the effect of the cation. Progress in Organic Coatings, v 44, n 2, p 111-120, 2002.

MONTEMOR, M. F.; SIMÕES, A. M.; FERREIRA, M. G. S. Composition and behaviour of cerium films on galvanized steel. Progress in Organic Coatings, $v$ 43, n 4, p 274-281, 2001.

MORGAN, S.W.K. Zinc and its Alloys and Compounds. E. H. L, Chi Chester, 1985.

MOROZOV, I. S. On Chemical Interaction of Niobium Pentoxide with Hydroxides of Rare Earth Metals, Titanium and Iron, v. 1, p. 791-798, 1956.

MOUANGA, M.; PUIGGALI, M.; DEVOS, O. EIS and LEIS investigation of ageing low carbon steel with Zn-Ni coating. Electrochimica Acta, 2013.

MURPHY, A. J. Surface Preparation and Finishes for Metals: a Manual Covering the Planning, Operations, and Economics Associated with Modern Metal Finishing. Society of Manufacturing Engineers, New York, 1971.

NARENDAR, Y., GARY, L. Messing Synthesis, Decomposition and Crystallization Characteristics of Peroxo-Citrato-Niobium: An Aqueous Niobium Precursor. Chemistry Materials, v 9, p 580-587, 1997.

NATORSKY, T.J.; Zinc and Zinc Alloy Plating in the 90's - Metal Finishing, v 90, p15-17, 1992.

NEUFELD, A. K. The initiation mechanism of corrosion of zinc by sodium chloride particle deposition. Corrosion Science, v 44, n 3, p 555-572, 2002.

NEVISON, D. C. H. ASM Handbook, 9th ed., ASM International, Materials Park, Ohio, v 13, p 755-769, 1987.

NOWAK, I.; ZIOLEK, M. Niobium compounds: preparation, characterization, and application in heterogeneous catalysis. Chemical Reviews, v 99, n 12, p 36033624, 1999.

ODNEVALL, I., LEYGRAF, C. Reaction sequences in atmospheric corrosion of zinc. ASTM Special Technical Publication, v 1239, p 215-215, 1995.

OLSSON, C. O. A. D. LANDOLT, Atmospheric Oxidation of a Nb-Zr Alloy Studied with XPS, Corrosion Science, v 46, n 1, p 213-224, 2004. 
PANOSSIAN, Z. Corrosão e Proteção Contra Corrosão em Equipamentos e Estruturas Metálicas, Instituto de Pesquisas Tecnológicas, v 1, 1 ed,1993.

PASÁN, Jorge. Ingeniería cristalina de complejos polinucleares: construcción de nuevos materiales moleculares. In: Anales de la Real Sociedad Española de Química. Real Sociedad Española de Química, 2011. p. 327-334.

PAVIA, D. L., LAMPMAN, G. M., KRIZ, G. S., VYVYAN, J. R. INTRODUÇÃO À ESPECTROSCOPIA, Editora: CENGAGE LEARNING, ed 1 ${ }^{\circ}, 2010$.

PENG, T., MAN, R. Rare earth and silane as chromate replacers for corrosion protection on galvanized steel. Journal of Rare Earths, v 27, n 1, p 159-163, 2009.

PORTER, F. C. Corrosion resistance of zinc and zinc alloys. CRC Press, 1994.

PORTER, F.C., STONEMAN, A.M., THILTHORPE, R.G. Trans IMF, v .66, p 28, 1988.

RAMANAUSKAS, R., GUDAVICIUTEA, L., DIAZ-BALLOTEB, L., BARTOLOPEREZ, B. P., QUINTANAB, P. Corrosion Behaviour of Chromated $\mathrm{Zn}$ and $\mathrm{Zn}$ Alloy Electrodeposits Surface and Coatings Technology, v 140, n 2:30, p109115, 2001.

RASPOLLI GALLETTI, A. M., PAMPALONI, G. Niobium complexes as catalytic precursors for the polymerization of olefins. Coordination Chemistry Reviews, v. 254, n 5, p 525-536, 2010.

REDSHAW, C. Highly Active, Thermally Stable, Ethylene-Polymerisation PreCatalysts Based on Niobium/Tantalum $\square$ Imine Systems. Chemistry-A European Journal, v 19, n 27, p 8884-8899, 2013.

ROSALBINO, F. et al. EIS study on the corrosion performance of a $\mathrm{Cr}$ (III)-based conversion coating on zinc galvanized steel for the automotive industry. Journal of Solid State Electrochemistry, v 15, n 4, p 703-709, 2011.

ROSCHMANN, K. et al. Corrosion protection coatings, U.S. Patent $n$. 8,460,445, 11 jun. 2013.

SAKHAROV, V. V. et al. Topo chemical Production of Niobium and Tantalum Hydroxide from Different Compounds, v 19, p 579-584, 1974.

SAKHAROV, V.V., KOROVKINA, N.B., MURAVLEV, YU.B., KORSHUNOV, B.G., Studies of the Composition of Amorphous Products of Hydrolysis of Crystalline Niobium Pentachloride, v 26, p 1493-1500, 1981.

SCHMITT, G. Global Needs for Knowledge Dissemination, Research, and Development in Materials Deterioration and Corrosion Control. The World Corrosion Organization, 2009. 
SCHONJAHN, C., PARITONG, H., MUNZ, W. D., TWESTEN, R. D., PETROV, I. Influence of the interface composition on the corrosion behavior of unbalanced magnetron grown niobium coatings on steel. Journal of Vacuum Science \& Technology A: Vacuum, Surfaces, and Films, 19(4), 1392-1398, 2001.

SCHOLES, F. H. et al. The role of hydrogen peroxide in the deposition of ceriumbased conversion coatings. Applied Surface Science, v 253, n 4, p 1770-1780, 2006.

SEN, B.K. AND SAHA, A.V., On the Nature and Structure of "Niobic Acid" and its Pyrolitic Products: Part II: Correlation between the Hydrates, the Stoichiometric and the Nonstoichiometric Oxides of Niobium (V), Mater. Res. Bull, v 17, p 161169, 1982.

SEN, U. Kinetics of niobium carbide coating produced on AISI 1040 steel by thermo-reactive deposition technique. Materials chemistry and physics, $v 86, \mathrm{n}$ 1, p 189-194, 2004.

SHAO, G., LU, Y., WU, F., YANG, C., ZENG, F., WU, Q. Graphene oxide: the mechanisms of oxidation and exfoliation. Journal of Materials Science, 47(10), 4400-4409, 2012.

SHORT, N.R. et all. Electrochemical Studies on the corrosion of a Range of Zinc Alloy Coated Steel in Alkaline Solutions. Surface and Coatings Technology, v 79, p. 218-224, 1996.

SHREEPATHI, S., BAJAJ, P., MALLIK, B. P. Electrochemical impedance spectroscopy investigations of epoxy zinc rich coatings: Role of $\mathrm{Zn}$ content on corrosion protection mechanism. Electrochimica Acta, v 55, n 18, p. 5129-5134, 2010.

SILVA, C.G. et al. The Molybdate-Zinc Conversion Process. Corrosion Science, v 51, 151-158, 2009.

SILVA, C.S., PEDROZO, M.F.M. Ecotoxicologia do Cromo e seus Compostos; Caderno de Referencia Ambiental, v 5, p 70-81, 2001.

SIOKOU, A.; NIX, R. M. Interaction of methanol with well-defined ceria surfaces: Reflection/absorption infrared spectroscopy, X-ray photoelectron spectroscopy, and temperature-programmed desorption study. The Journal of Physical Chemistry B, v 103, n 33, p 6984-6997, 1999.

SOCRATES, G. Infrared Characteristic Group Frequencies. 2nd Ed. Chichester: Wiley, 1994.

STANKIEWICZ, A., SZCZYGIEŁ, I., SZCZYGIEŁ, B. Self-healing coatings in anticorrosion applications. Journal of Materials Science, v 48, n 23, p 80418051, 2013. 
STRATMANN, M.; FESER, R.; LENG, A. Corrosion protection by organic films. Electrochimica Acta, v 39, n 8, p 1207-1214, 1994.

SYCH, A. M., KLENUS, V. G. Lanthanum, cerium, praseodymium, and neodymium titanoniobates. Inorg. Mater (Engl. Transl.), v 9, n 7, p 1081-1084, 1973.

TAHERI, P., WIELANT, J., HAUFFMAN, T., FLORES, J. R., HANNOUR, F., DE WIT, J. H. W., TERRYN, H. A comparison of the interfacial bonding properties of carboxylic acid functional groups on zinc and iron substrates. Electrochimica Acta, 56(4), 1904-1911, 2011.

TANABE, K. Catalytic application of niobium compounds. Catalysis Today, v 78, n 1, p. 65-77, 2003.

TAOUIL, E.T. et al. Corrosion protection by sono electrodeposited organic films on zinc coated steel. Ultrasonic sonochemistry, v 19, n 6, p 1186-1193, 2012.

THOMPSON, G.E. UMIST, Conversion Coatings. TALAT Lecture 5202, Manchester, 1994.

THOMPSON, G.E., WOOD, G.C. J.C. Scully (Ed.), Anodic Films on Aluminum; Reactions at the oxide-electrolyte interface of anodic oxide films on aluminum, 1983.

TOMACHUK, C. R. et al. Morphology and corrosion resistance of $\mathrm{Cr}$ (III)-based conversion treatments for electrogalvanized steel. Journal of Coatings Technology and Research, v 7, n 4, p 493-502, 2010.

TORPY, M. F. Electroplating and cyanide wastes Journal (Water Pollution Control Federation) Vol. 52, No. 6, 1980: Literature Review, p. 1451-1455, 1980.

TRABELSI, W. Electrochemical assessment of the self-healing properties of Cedoped silane solutions for the pre-treatment of galvanised steel substrates. Progress in Organic Coatings, v 54, n 4, p 276-284, 2005.

TSONCHEVA, T., ISSA, G., BLASCO, T., CONCEPCION, P., DIMITROV, M., HERNÁNDEZ, S., LÓPEZ NIETO, J. M. Silica supported copper and cerium oxide catalysts for ethyl acetate oxidation. Journal of Colloid and Interface Science, 2013.

USHIKUBO, T. Recent topics of research and development of catalysis by niobium and tantalum oxides. Catalysis Today, v 57, n 3, p 331-338, 2000.

VERMA, A., SINGH, P. K. Sol-gel derived nanostructured niobium pentoxide thin films for electro chromic applications. Indian Journal of Chemistry, v 52, p 593$598,2013$. 
VEYS-RENAUX, D. New zinc-rare earth alloys: Influence of intermetallic compounds on the corrosion resistance. Corrosion Science, v 77, p 342-349, 2013.

VICKERY. Chemistry of the Lanthanons, Academic Press, Inc., New York, p 105 $-252,1953$.

VOLOVITCH, P., MOKADDEM, M., OGLE, K. The anodic dissolution of zinc and zinc alloys in alkaline solution. I. Oxide formation on electrogalvanized steel, Electrochimica Acta, 55, 7867, 2010.

WANG, H., AKID, R. Encapsulated cerium nitrate inhibitors to provide highperformance anti-corrosion sol-gel coatings on mild steel. Corrosion Science, v. 50, n 4, p 1142-1148, 2008.

WANG, M-H., GUO, R. J., TSO, T.L., PERG, T. P. Effects of sintering on the on the photo electrochemical properties of $\mathrm{Nb}$-doped $\mathrm{TiO}_{2}$ electrodes. International Journal of Hydrogen Energy, v 20, n 7, 555-560, 1995.

WERNICK, PINNER AND SHEASBY: The Surface Treatment and Finishing of Aluminium and Alloys, Fifth Edition, Volume 1, ASM International Finishing Publications Ltd, England 1987.

WESSLING, B., POSDORFER, J. Corrosion prevention with an organic metal (polyaniline): corrosion test results. Electrochimica Acta, v 44, n 12, p 21392147, 1999.

WESTBROOK, J.H. Materials: History Since 1800, Encyclopedia of Materials Science and Engineering M.B. Bever, Ed., Pergamon Press, p 2827-2838, 1986.

XIA, L. Storage and Release of Soluble Hexavalent Chromium from Chromate Conversion Coatings Equilibrium Aspects of $\mathrm{Cr} \mathrm{VI}$ Concentration. Journal of The Electrochemical Society, v 147, n 7, p 2556-2562, 2000.

XIE, Y., SHERWOOD, P. M. X-ray photoelectron-spectroscopic studies of carbon fiber surfaces. 11. Differences in the surface chemistry and bulk structure of different carbon fibers based on poly (acrylonitrile) and pitch and comparison with various graphite samples. Chemistry of Materials, 2(3), 293-299, 1990.

YADAV, A. P., NISHIKATA, A., TSURU, T. Degradation mechanism of galvanized steel in wet-dry cyclic environment containing chloride ions. Corrosion Science, v 46, p361-376, 2004.

YAHAYA, A I., Chromium in Soils a Review of its Distribution and impacts. Continental Journal Environmental Sciences, 2009.

YAMAGUTI, R. C. de L. Avaliação de alternativas ao uso de níquel e cromatos no processo de fosfatização tricatiônico aplicado ao aço carbono. 2012. Tese (Doutorado em Tecnologia Nuclear - Materiais) - Instituto de Pesquisas Energéticas e Nucleares, Universidade de São Paulo, São Paulo, 2012. 
YOST; D. M., RUSSEL JR, H., GARNER, C. S. The Rare Earth Elements and Their Compounds. John Wiley \& Sons, Inc. New York, p 92, 1947.

ZANDI ZAND, R., VERBEKEN, K., ADRIAENS, A. Electrochemical assessment of the self-healing properties of cerium doped sol-gel coatings on $304 \mathrm{~L}$ stainless steel substrates. International Journal of Electrochemical Science, v 7, n 10, p 9592-9608, 2012.

ZANDI ZAND, R., VERBEKEN, K., ADRIAENS, A. Evaluation of the corrosion inhibition performance of silane coatings filled with cerium salt-activated nanoparticles on hot-dip galvanized steel substrates. International Journal of Electrochemical Science, v 8, n 4, p 4927-4940, 2013.

ZHANG, X. G. Corrosion and Electrochemistry of Zinc. Plenum Press, New York, 1996.

ZHANG, X.; VAN, C.; DEN, B. Comparison of the morphology and corrosion performance of $\mathrm{Cr}(\mathrm{VI})$ - and $\mathrm{Cr}(\mathrm{III})$-based conversion coatings on zinc. Surface \& Coatings Technology, 199, v 1, p 92- 104, 2005.

ZHAO, J., FRANKEL, G., MCCREERY, R. Corrosion Protection of Untreated AA2024-T3 in Chloride Solution by a Chromate Conversion Coating Monitored with Raman Spectroscopy. Journal of Electrochemical Society, v 145, n 2258, 1998.

ZHAO, J., XIA, L., SEHGAL, A., LU, D., MCCREERY, R.L., FRANKELB, G.S. Effects of Chromate and Chromate Conversion Coatings on Corrosion of Aluminum Alloy 2024-T3. Surface and Coatings Technology, v140, n 57, 2001.

ZUCKERMAN, TOD. Chromium (VI) as the Basis for a Toxic Tort-a Legal Perspective. 2004. 